DR. 251

ORNL/TM-6626/V1

\title{
Assessment of an Atmospheric Fluidized-Bed Coal-Combustion Gas-Turbine Cogeneration System for Industrial Application
}

R. L. Graves

R. S. Holcomb

J. R. Tallackson

OPERATED BY

UNION CARBIDE CORPORATION FOR THE UNITED STATES DEPARTMENT OF ENERGY 


\section{DISCLAIMER}

This report was prepared as an account of work sponsored by an agency of the United States Government. Neither the United States Government nor any agency Thereof, nor any of their employees, makes any warranty, express or implied, or assumes any legal liability or responsibility for the accuracy, completeness, or usefulness of any information, apparatus, product, or process disclosed, or represents that its use would not infringe privately owned rights. Reference herein to any specific commercial product, process, or service by trade name, trademark, manufacturer, or otherwise does not necessarily constitute or imply its endorsement, recommendation, or favoring by the United States Government or any agency thereof. The views and opinions of authors expressed herein do not necessarily state or reflect those of the United States Government or any agency thereof. 


\section{DISCLAIMER}

Portions of this document may be illegible in electronic image products. Images are produced from the best available original document. 


\section{Printed in the United States of America. Available from National Technical Information Service \\ U.S. Department of Commerce \\ 5285 Port Royal Road, Springfield, Virginia 22161 \\ NTIS price codes-Printed Copy: A09 Microfiche A01}

This report was prepared as an account of work sponsored by an agency of the United States Government. Neither the United States nor any agency thereof, nor any of their employees, makes any warranty, expressed or implied, or assumes any legal liability or responsibility for any third party's use or the results of such use of any information, apparatus, product or process disclosed in this report, or represents that its use by such third party would not infringe privately owned rights. 
ORNL/TM-6626/V1

Dist. CategoryiuC-90e

Contract No. W-7405-eng-26

Engineering Technology Division

\section{ASSESSMENT OF AN ATMOSPHERIC FLUIDIZED-BED COAL- COMBUSTION GAS-TURBINE COGENERATION SYSTEM \\ FOR INDUSTRIAL APPLICATION}

R. L. Graves

R. S. Holcomb

J. R. Tallackson

Date Published: October 1979

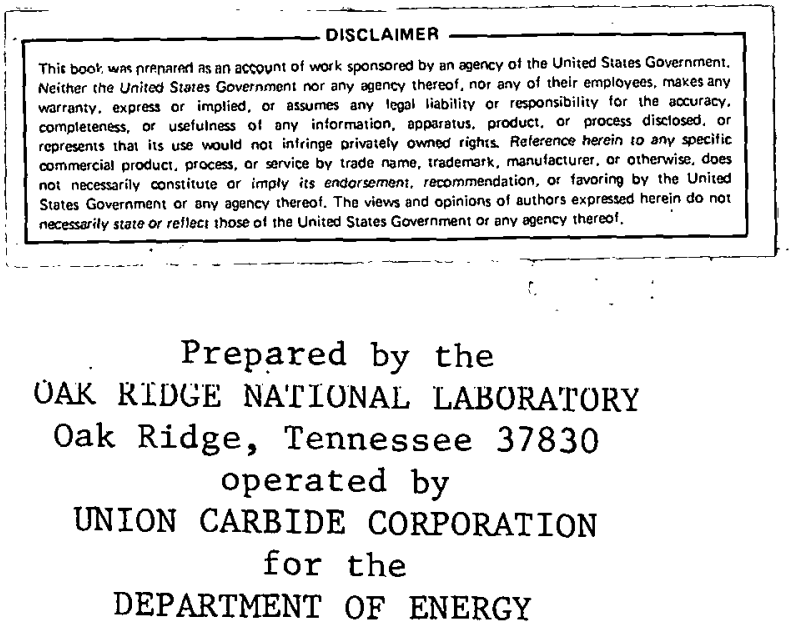




\section{THIS PAGE WAS INTENTIONALLY LEFT BLANK}




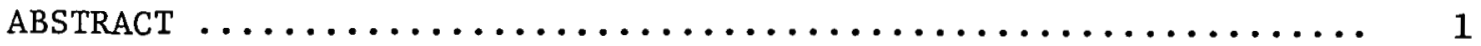

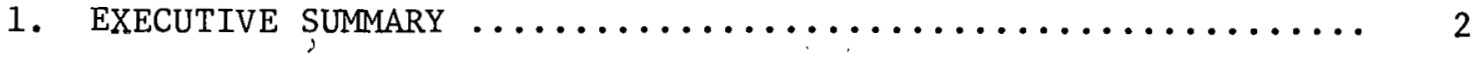

1.1 Theoretical Potential Market $\ldots \ldots \ldots \ldots \ldots \ldots \ldots \ldots \ldots .2$

1.2 Impact on $0 i 1$ and Natural Gas Consumption ........... 2

1.3 Thermodynamic Feasibility $\ldots \ldots \ldots \ldots \ldots \ldots \ldots \ldots \ldots \ldots .4$

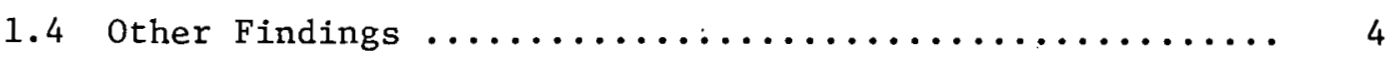

1.5 Recommendations $\ldots \ldots \ldots \ldots \ldots \ldots \ldots \ldots \ldots \ldots \ldots \ldots \ldots$

References .............................. 7

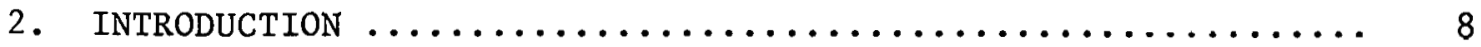

2.1 Need for Coal-Combustion Cogeneration Systems ........ 8

2.2 Proposed Cogeneration System .................. 10

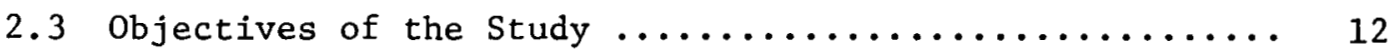

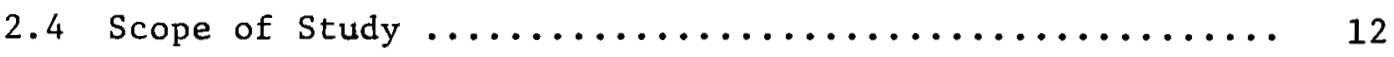

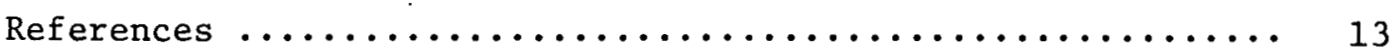

3. ENERGY CONSUMPTION IN THE UNITED STATES AND BY INDUSTRY $\ldots . . .14$

3.1 Energy Usage in the United States and by Industry ..... 14

3.2 U1timate Use of Energy Purchased by Industry ........ 24

3.3. Energy Consumption for Process Heat ............. 27

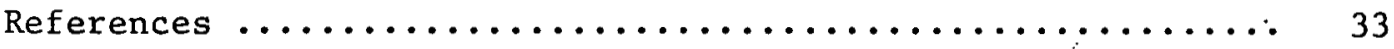

4. FEASIBILITY OF COGENERATION SYSTEMS FOR GENERATING

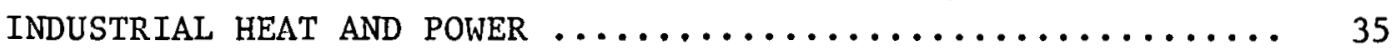

4.1 Cogeneration Prime Mover Characteristics .......... 36

4.2 Temperature Requirements for Industrial Process Heat ... 43

4.3 Process Heat/Temperature and Power Consumption in the Six Major Industries ................... 46

4.3.1 Primary metals .................... 47

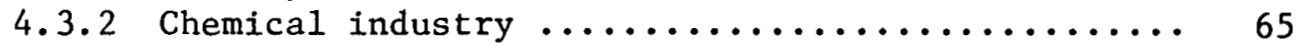

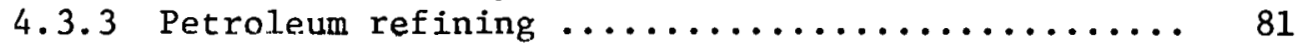

4.3.4 Paper and pulp industry ................ 89

4.3.5 Stone/clay/glass industries ............. 91

4.3 .6 Fond industry $\ldots \ldots \ldots \ldots \ldots \ldots \ldots \ldots \ldots \ldots \ldots \ldots \ldots$

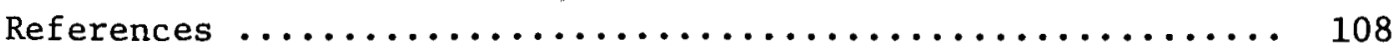

5. ANALYSIS OF GAS-TURBINE COGENERATION SYSTEMS FOR SELECTED INDUSTRIES AND PROCESSES $\ldots \ldots \ldots \ldots \ldots \ldots \ldots \ldots \ldots \ldots \ldots \ldots \ldots \ldots \ldots \ldots \ldots$

5.1 Analysis of Fluidized-Bed Furnace ............. 111 
Page

5.2 Industries Selected for Application ............ 115

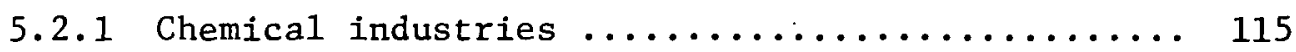

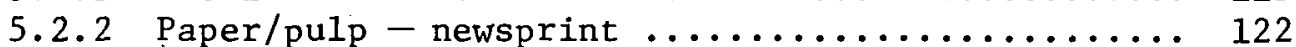

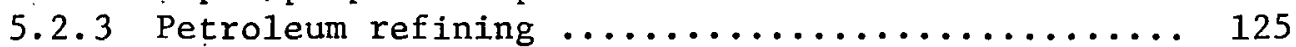

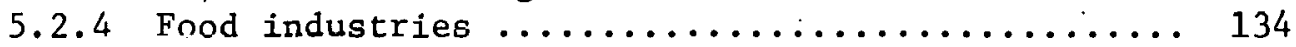

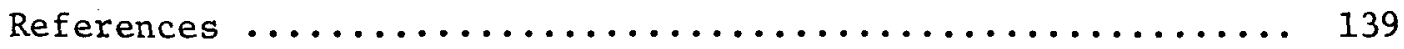

6. CONCEPTUAL DESIGN OF AFBC GAS-TURBINE COGENERATION SYSTEMS

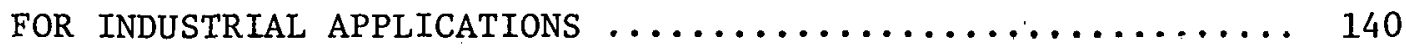

6.1 Combustor Design ....................... 140

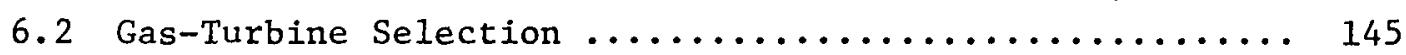

7. ECONOMIC COMPARISON OF COGENERATION SYSTEM WITH

ALTERNATIVES ............................ 147

7.1 Assumptions Used for Cost Estimates ............... 147

7.2 Coa1-Combustion Cogeneration System ............. 149

7.3 Pulverized Coal-Fired Boilers .................. 149

7.4 AFBC Coal-Fired Boilers ................... 149

7.5 0il-Fired Package Boiler ................... 152

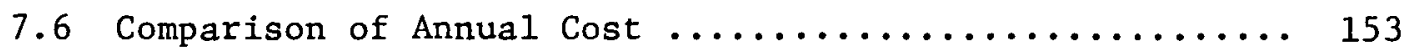

8. CONCLUDING REMARKS AND RECOMMENDATIONS .............. 157

0.1 Theorericál fotential Market ................ 157

8.2. Impact on $0 i 1$ and Natural Gas rnnsumption ......... 157

8.3 Thermodynamic Feasibility $\ldots \ldots \ldots \ldots \ldots \ldots \ldots \ldots \ldots \ldots \ldots$

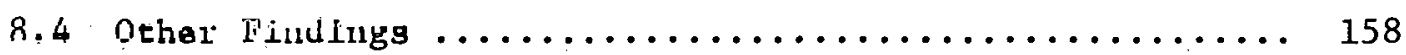

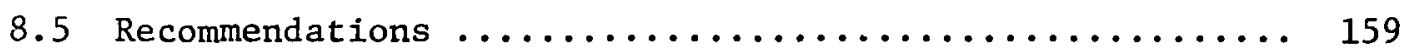

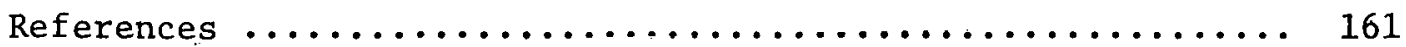

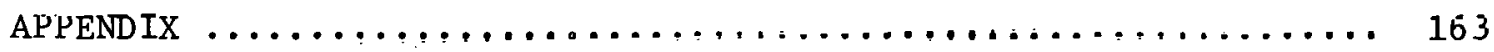




\title{
ASSESSMENT OF AN ATMOSPHERIC FLUIDIZED-BED COAL- COMBUSTION GAS-TURBINE COGENERATION SYSTEM FOR INDUSTRIAL APPLICATION*
}

\author{
R. L. Graves \\ R. S. Holcomb \\ J. R. Tallackson
}

\section{ABSTRACT}

This study was initiated to provide information on the future potential industrial market for a cogeneration system consisting of a fluidized-bed coal combustor coupled to a gas-turbine (Brayton cycle) power system that uses air as the working fluid.

In assessing the potential applications for the system, the process heat energy consumption by industry is identified, with special detail included on the six most energyintensive industries. The potential impact on the nation's oil and natural gas consumption that would result from widespread utilization of coal for process heat is also estimated.

The fraction of industrial process heat that the system could feasibly satisfy from a thermodynamic viewpoint is cstimated, and the performance (potential fuel efficiency and heat/power ratio) of the atmospheric fluidized-bed gas-turbine system is calculated. Also treated are several specific case studies of industries in which the system could be incorporated. Major parameters are specified, and flow sheets are derived for systems that would satisfy the heat and power. requirements of the process or industry. The overall fuel utilization efficiency, thermal power rating, and potential number of installations are specified for these case studies.

The findings of the study indicate that there is a sizable potential market for the system, with over 1000 possible installations disclosed after reviewing only 8 specific industries from 6 major Standard Industrial Classification (SIC) groups. The potential displacement of oil and gas by coal in process heating is shown to be about $1.60 \mathrm{~m}^{3} / \mathrm{sec}(870,000 \mathrm{bbl} /$ day) of oil and $4590 \mathrm{~m}^{3} / \mathrm{sec}\left(14.0\right.$ billion $\mathrm{ft}^{3} /$ day) of natural gas for all industries combined. Continued development of the fluidized-bed coal combustor and power system is recommended so that this potential may be at least partially realized.

*The following conversion factors may be useful in reviewing this report: $1 \mathrm{ft}^{3}$ of natural gas $=1035 \mathrm{Btu}(1087 \mathrm{~kJ}), 1$ bbl of oil $=5.8 \times$ $10^{6} \mathrm{Btu}\left(6.1 \times 10^{6} \mathrm{~kJ}\right)$, and 1 ton of coal $=2.6 \times 10^{7}$ Btu $\left(2.7 \times 10^{7} \mathrm{~kJ}\right)$. 


\section{EXECUTIVE SUMMARY}

This document reports the findings of a six-month study assessing the potential applications for a candidate industrial cogeneration system consisting of a fluidized-bed coal combustor driving a gas-turbine (Brayton cycle) power system. The system studied is shown in a flow diagram in 'Fig. 1.1. The study was carried out with three major objectives, each instrumental in reaching the overall objective cited above: $(1)$ identify the potential industrial market for the system; (2) estimate the Impact on the nation's oil and natural gas consumption; and (3) determine the thermodynamic feasibility and performance of the system. Significant findings with regard to these objectives are summarized in the following sections.

\subsection{Theoretical Potential Market}

The ability to satisfy industrial energy requirements primarily determines the applicability of the system, specifically, the use of process heat and electricity. Thus the potential market should be discussed in terms of energy as well as the number of installations. Based on extrapolation from the six largest users of industrial energy, the energy consumption for process heating was estimated as $15,750 \times 10^{12} \mathrm{~kJ}(15,000 \times$ $10^{12} \mathrm{Btu}$ ) (in 1974), which is $450 \%$ of the total industrial burden on primary energy sources (fuels) and $\sim 19 \%$ of the total United States burden on primary fuels. Thus the "thermal market" for the coal-combustor cogeneration (CCC) system is substantial, especially in view of the recent thrust toward increased use of coal.

\subsection{Impact on Uil and Natural Gas Consumption}

The reduction in use of natural gas and oil is of paramount importance, and the ability to use more available fuels is a primary factor in determining the desirability of any cogeneration systems. Typically 90 to $92 \%$ of the oil and gas purchased by industry (excluding feedstocks) is used for heat. Thus the oil and gas presently consumed for process heat which theoretically could be displaced by coal can be identified. 
ORNL-DWG 78-3285R

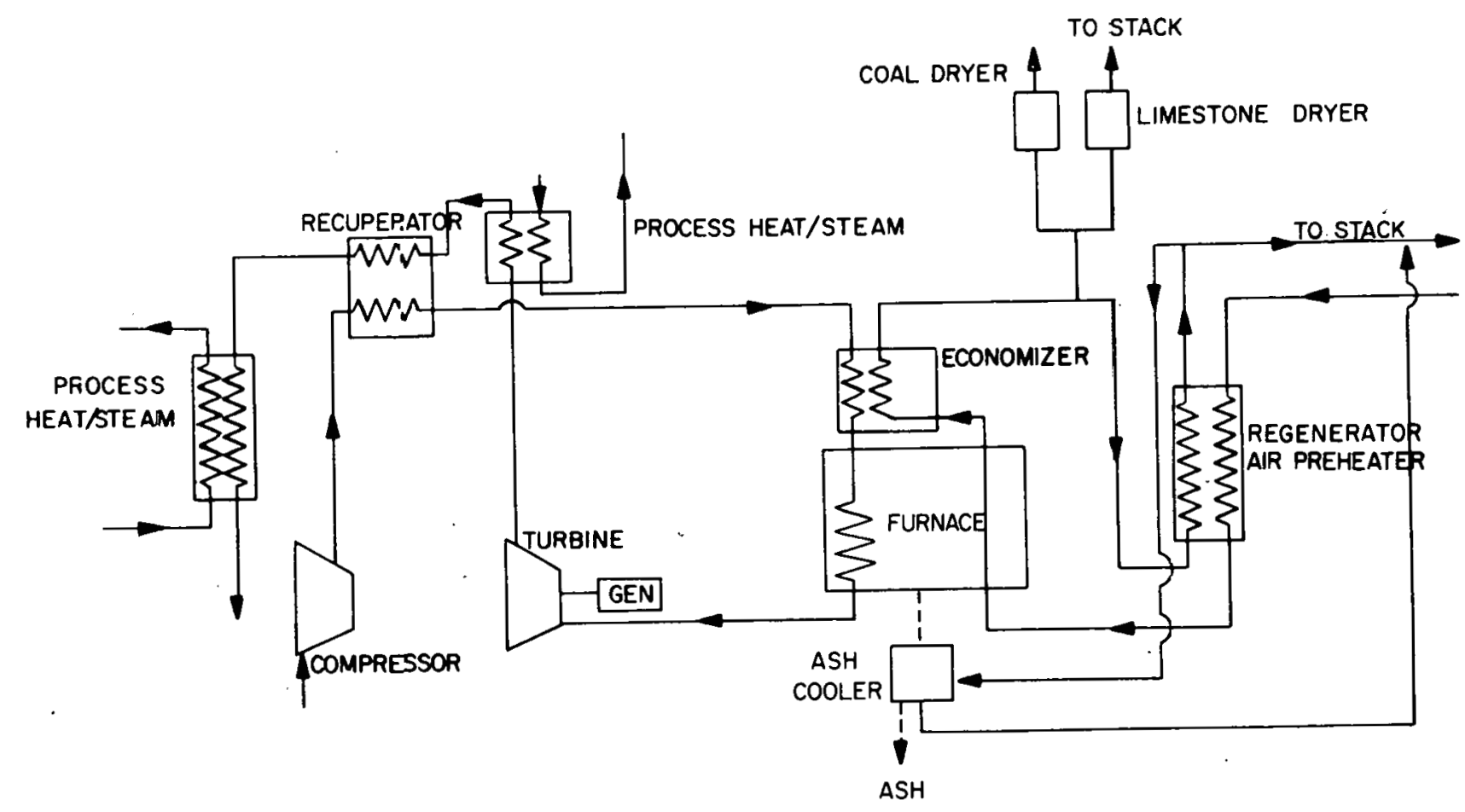

Fig. 1.1. Atmospheric fluidized-bed coal-combustion gas-turbine cogeneration system. 
The consumption values are listed in Table 1.1. A very large conservation potential exists for the nation's gas resources, as well as a substantial potential savings for oil.

Table 1.1. Estimated annual oil and gas consumption for industrial process heating

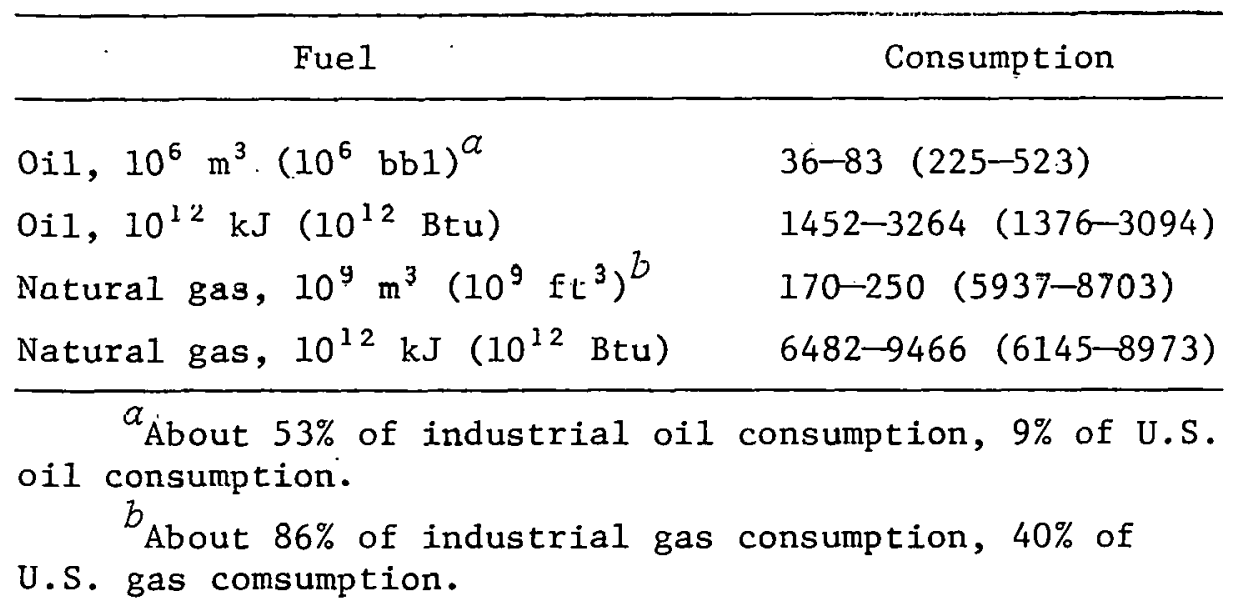

\subsection{Thermodynamic Feasibility}

The capability of the CCC system to supply useful thermal process energy at temperatures up to $816^{\circ} \mathrm{C}\left(1500^{\circ} \mathrm{F}\right)$ while simultanenusly producing electric power enhances the system's thermodynamic feasibility in satisfying process heat demands in industry. The high-temperature heating capacity of the gas-turbine system is unique among cogeneration sysLems, particularly those burning coal. From data on the temperature spectrum of process heating, the conclusion is reached that 61 to $64 \%$ of the energy is required at temperatures less than $816^{\circ} \mathrm{C}\left(1500^{\circ} \mathrm{F}\right)$. The thermodynamically feasible potential for CCC fuel conversion appears in Table 1.2.

\subsection{Other Findings}

Specific case studies were investigated on a preliminary basis to gain some insight into the actual fuel efficiency that is probable with 
Table 1.2. Thermodynamically feasible savings of oil and gas with $\operatorname{ccc}^{a}$

\begin{tabular}{|c|c|c|c|}
\hline Fuel & $\begin{array}{l}\text { Savings from process } \\
\text { heat conversion } \\
\text { to coal }\end{array}$ & $\begin{array}{l}\text { Savings from electrical } \\
\text { generation by coal } \\
\text { cogeneration }\end{array}$ & Total \\
\hline Oil, $\mathrm{m}^{3} / \sec (\mathrm{bb} 1 /$ day) & $1.60(870,000)$ & $1.17(635,000)$ & $2.77(1,505,000)$ \\
\hline $\begin{array}{l}\text { Natural gas, } \mathrm{m}^{3} / \mathrm{sec} \\
\left(10^{9} \mathrm{ft}^{3} / \mathrm{day}\right)\end{array}$ & $4,590(14.5)$ & $1,228(3.75)$ & $5,818(17.75)$ \\
\hline
\end{tabular}


the system. Practical problems were discussed where sufficient information existed. The market for about 1000 CCC units was identified on investigation of only 8 specific industries, including petroleum refining, food processing, and chemical manufacturing. Typical fuel efficiencies were on the order of $70 \%$. However, the value of in-plant electric generation alone may prove to be an equally significant advantage for industry.

The advantages of in-house power generation with CCC systems will be increased if electrical energy becomes a more prominent and effective method of producing high-temperature energy for such processes as ferrous metal heating, metal reheating for hot forming (e.g., forging), and glass mielting.

\subsection{Recommendations}

This survey was developed with the underlying premise that coal will become the preferred source of environmentally acceptable industrial energy. Fluidized-bed combustors, now in the development stage, conceptually satisfy this premise. The theoretical future market disclosed by this survey is a clear mandate to proceed with concentrated engineering and development programs designed to realize the full technological potential of CCC systems. Technological barriers to implementation of fluidized beds have recently been summarized in Ref. 1.

A recent study by Thermo Electron Corporation ${ }^{2}$ estimated that a very high percentage of industry would invest in cogeneration systems provided a reasonable investment return over time would result. 'l'he most accurate economic data would be generated by several representative, detailed case studics of specific industrial facilities.

Cogeneration by industry is receiving much attention at this time and is highly recommended in the literature. ${ }^{2-4}$ The continued development of the equipment described in this report, resulting in a vendormanufactured product, would be instrumental in accelerating the implementation of coal-burning cogeneration. 


\section{$\underline{\text { References }}$}

1. J. E. Jones, Jr., et al., Systems Assessment of Atmospheric Fluidized Bed Combustion: Baseline Study, ORNL/TM-6208 (December 1977).

2. Thermo Electron Corporation, A Study of Inplant Electric Power Generation in the Chemical, Petroleum Refining and Paper and Pulp Industries, TE5429-97-76, 1976.

3. National Consumer Research Institute, Proceedings of the ERDA Conference on Cogeneration and Integrated Energy/Utility Systems, CONF-770632, 1977.

4. E. V. Sherry, Energy Conservation by Symbiosis, Air Products and Chemical, Inc., Allentown, Pa., 1977. 


\section{INTRODUCTION}

\subsection{Need for Coal-Combustion Cogeneration Systems}

The uncertainties concerning the extent of the supplies of natural gas and petroleum and further uncertainties pertaining to their cost have helped initiate the thrust to use more available fuels, primarily coal. The industrial sector is the largest consumer of natural gas and is also somewhat dependent on petroleum products. Industry, therefore, both by this fact and its general nature, is considered perhaps the most likely energy-consuming sector for conversion to the use of coal. Prerequisite to the conversion to coal is the demonstration of techniques to satisfy $\mathrm{SO}_{2}$ emission requirements. Furthermore, because coal is a nonrenewable fuel, coal must be utilized in the most efficient manner possible. The fluidized-bed coal combustor in conjunction with a cogeneration power system appears to offer the potential for achieving both objectives cited.

The sulfur retention possible with fluidized-bed combustors appears to be sufficient for the anticipated Environmental Protection Agency (EPA) standards for $\mathrm{SO}_{2}$ emissions. The sulfur retention capabilities and other characteristics of fluidized-bed coal combustion are summarized comprehensi.vely in Ref. 1.

The broad conservation potential of cogeneration systems is best explained by referring to the thermodynamic concepts of efficiency and effectiveness. A corollary of the second law of thermodynamics is that a power system operating on a thermodynamic cycle must reject a portion of the thermal energy received from a high-temperature source to a lowertemperature reservoir. A conventional steam-electric utility plant rejects this thermal energy, isially to a body of water or lo lihe alimusphere. The rejected heat for a conventional plant totals $265 \%$ of the energy of the raw coal; thus the efficiency of such a plant is only $35 \%$ because the rejected heat is not utilized for a productive purpose. However, if a neighboring industry could utilize $80 \%$ of the utility's waste energy, the efficiency of the combined electricity production and heat utilization would be $87 \%$, that is, $87 \%$ of the energy of the coal would 
be used for productive purposes. A system of this type which produces electricity and utilizes "waste" energy (usually as process heat in industry) is, by definition, a cogeneration system. Its fuel conservation potential is evident in the previous example.

The concept of effectiveness is more abstract, but it is quantitative and subject to analysis and has received considerable attention in recent literature dealing with conservation. ${ }^{2,3}$ The effectiveness of a power system, for example, would be the degree to which that system is successful in converting the energy available from a process involving the release of thermal energy (combustion) into useful work (electricity). To maximize the effectiveness, two simplified requirements for the power system are (1) the peak temperature should be as close as possible to the temperature of the energy source, and (2) the waste heat should be rejected at a temperature as close as possible to the temperature of the environment.

The available energy that can be converted into electricity is somewhat more limited than energy in general. The availability of an energy source can be visualized as its potential for producing work (electricity) and is primarily a function of the temperature of the source. For instance, coal combustion produces a high-temperature, high-availability energy source. The ocean, in contrast, possesses tremendous amounts of energy but relatively little availability. The desirability of highly effective systems that utilize the availability of an energy source is summarized by the following statements.

1. Electricity is a versatile, highly refined, and valuable form of energy and can be generated only where there is energy of sufficient availability.

2. Availability is a nonrenewable resource just as a fuel.

The conservation of availability would be affected by reducing the quantity of refined fuels burned at high temperature for the sole purpose of providing process heat at a substantially lower temperature. Thus the conservation of availability is indeed an argument for cogeneration.

The potential for relieving the shortage of generating capacity currently being experienced by utilities is another advantage that should 
be mentioned. Further cases in favor of cogeneration are well represented in the 1iterature. ${ }^{4,5}$

\subsection{Proposed Cogeneration System}

A recuperative gas-turbine cycle used in conjunction with the fluidized bed is capable of belng both a high-effectiveness and a high-efficiency cogeneration system. Varlable degrees of recuperation allow the system to satisfy a wide range of electricity and process heat needs for the various industries. Its potential for simultaneously producing electricity and high-temperature process heat is unique among cogeneration systems. The basic layout of the system 1s shown in Fig. 2.1. The syetem differs from that of a conventional oil-f1red gas turbine in that air is heated in the fluidized-bed furnace and is used as the working fluid in the turbine in lieu of combustion gases. The recuperator may be up to $85 \%$ effective or nonexistent in cases of high-heat/power requirements. The compressor pressure ratio will typically range from 2 to a practical upper limit of about 7 , where the power per pound of air flow is near maximum for a turbine inlet temperature of about $816^{\circ} \mathrm{C}\left(1500^{\circ} \mathrm{F}\right)$. Because of the need for high sulfur retention, the combustion temperature in the bed would be limited to about $871^{\circ} \mathrm{C}\left(1600^{\circ} \mathrm{F}\right)$, which can provide a turbine inlet temperature of about $816^{\circ} \mathrm{C}\left(1500^{\circ} \mathrm{F}\right)$.

The furnace operates at atmospheric pressure. An economizer heat exchanger in the upper part of the furnace extracts heat from the combustion gases before they leave the furnace. The flue gases are then used to dry the coal and limestone (If necessary) and to heat the incoming combustion air in a regenerative capacity. A flue-gas stack temperature of $2149^{\circ} \mathrm{C}\left(300^{\circ} \mathrm{F}\right)$ was arbltrarlly selected in establishing ground rules for the study. Heat recovery from the sollds rejected from the bed is also practiced.

The effectiveness of the system is such that, with adequate recuperation, " $30 \%$ of the coal energy can be convertcd to electricity while maintaining an overall efficiency of up to $85 \%$. If an industry's electrical requirements involve significant load variations, the system can be made closed cycle, provided there is an ample heat sink to cool the 


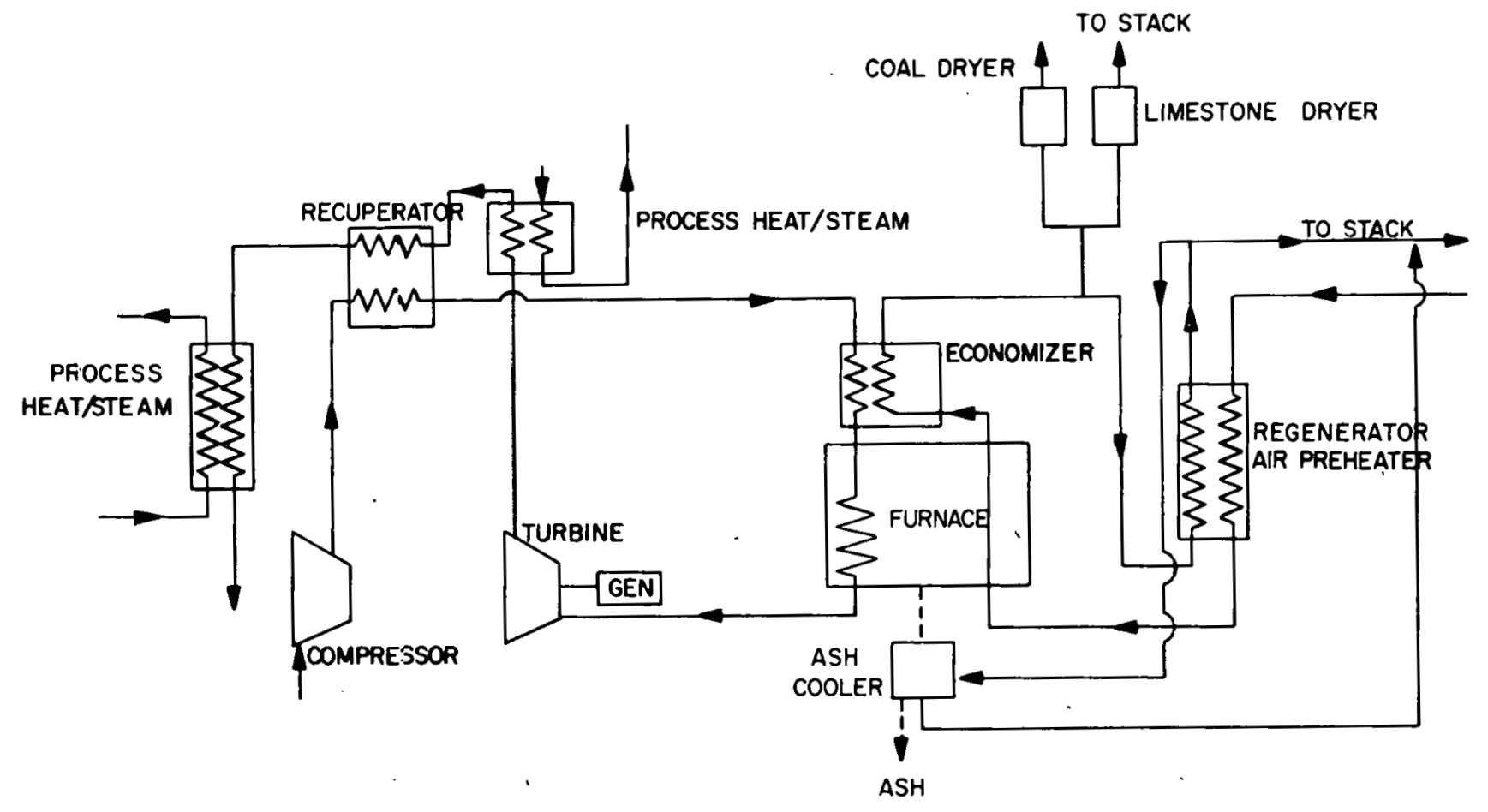

Fig. 2.1. Fluidized-bed gas-turbine cogeneration system. 
compressor intake charge. The closed-cycle cogeneration system can maintain its effectiveness during shifts in electrical load.

\subsection{Objectives of the Study}

Having identified the $\mathrm{CCC}$ as a candidate system for industrial cogeneration, the specific objectives of this study can be outlined.

\subsubsection{Identify potential market for system}

The industrial energy requirements, particularly the temperature required, will primarily determine the applicability of the system. A number of typical installations are to be identified.

\subsubsection{Estimate impact on oil and natural gas consumption}

The reduction in use of natural gas and oil is a major concern, and the ability to accomplish such a reduction is a primary factor in determining the desirability of any cogeneration system. However, if coal-fired technology cannot be demonstrated as being economically competitive with current oil and gas prices, it can be argued that conservation of these fuels has not yet reached its ultimate degree of urgency.

\subsubsection{Determine feasibility of system}

The capability of the system to supply heat at specific temperatures and adequate electricity to specific plant processes will be determined. This system-process matching is the first test of feasibility, with economic and practical considerations to be examined in secondary roles at this time.

\subsection{Scope of Study}

The primary focus of the study in regard to the objectives cited will be on the six largest consumers of process heat in the industrial sector: (1) iron and steam manufacture, (2) petroleum refining, (3) chemical manufacture, (4) stone/clay/glass production, (5) food processing, and (6) paper/pulp production. Limited data on other industries are also included. 
Economic questions and the practical problems of interfacing the CCC with industry are given minor attention. These questions are best answered in specific, detailed case studies involving specific manufacturing installations.

\section{$\underline{\text { References }}$}

1. T. E. Dowdy et al., Sumary Evaluation of Atmospheric Pressure Fluidized Bed Combustion Applied to Electric Utility Large Steam Generators, EPRI FP-308, Babcock \& Wilcox Company (October 1976).

2. Federal Energy Administration, The Data Base, The Potential for Energy Conservation in Nine Selected Industries, Vol. 2 - Petroleum Refining, office of Industrial Programs, 1975.

3. Evaluation of the Theoretical Potential for Energy Conservation in Seven Basic Industries, FEA/D-75/CE1, Battelle Columbus Laboratories (July 1975).

4. The Institute of Fuel, Total Energy Conference Brighton 1971, Proceedings, Vol. 1, London, 1971.

5. National Consumer Research Institute, Proceedings.of the ERDA Conference on Cogeneration and Integrated Energy/Utility Systems, CONF770632,1977 . 


\section{ENERGY CONSUMPTION IN THE UNITED STATES AND BY INDUSTRY}

The general energy consumption pattern in the United States is valuable in placing the industrial consumption into perspective. This chapter presents a general discussion and generalized data, followed by data of increasing detail. Quantities of oil and gas used for industrial process heating are identified.

\subsection{Energy Usage in the United States and by Industry}

Assessments of fuel usage potential brought about by the development of new hardware or new schemes for using old hardware will take into account the overall energy involved and how and in what forms that energy is used and distributed among the different using sectors. In a preliminary evaluation such as this, gross and generalized.comsumption data will provide a qualitative indication of the possible benefits that will result if engineering developments enable desirable shifts in our existing pattern of primary energy consumption.

rigures 3.1 through 3.4 display the primary energy consumption in 1974 and distribution among the three user groups: (1) residential and commercial, (2) industrial, and (3) transporatinn. Tahle 3.1 (Ref.1) cunsolidatès these data; note that the energy used by the utilities (sector 4) is embedded in the end-use sectors, 1 through 3. Figure 3.5 (Ref. 2) shows relative comsumptions by industrial. groups. Because $80 \%$ of all process energy is consumed by the first six, this evaluation will tend to concentrate on (1) chemicals, (2) primary metals, (3) petroleum refining, (4) pulp and paper, (5) stone, clay, glass, and cement, and (6) food. The role played by fuels used for feedstock is quite significant in some industries. Thus the following clarification is quoted from the 1972 Census of Manufacturers ${ }^{2}$ for the data in Fig. 3.5.

Data on fuels produced and concumed in the same establishment (such as coke-oven gas or blast-furnace gas); data on fuels used as raw materials (such as fuel oil and natural gas used to produce carbon black); and fuels converted to other fuel types (such as coal converted to coke) were not obtained in the 1971 survey... 
TOTAL 1974 U.S. ENERGY CONSUMPTION (\%)

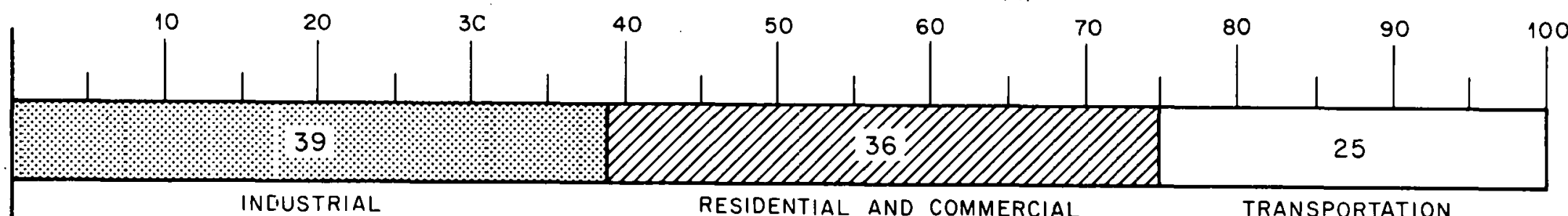

INLUSTRIAL

RESIDENTIAL AND COMMERCIAL

TRANSPORTATION

IJ.S. ENERGY CONSUMPTION IN $10^{15} \mathrm{Btu}(1 \mathrm{Btu}=1.055 \mathrm{~kJ})$

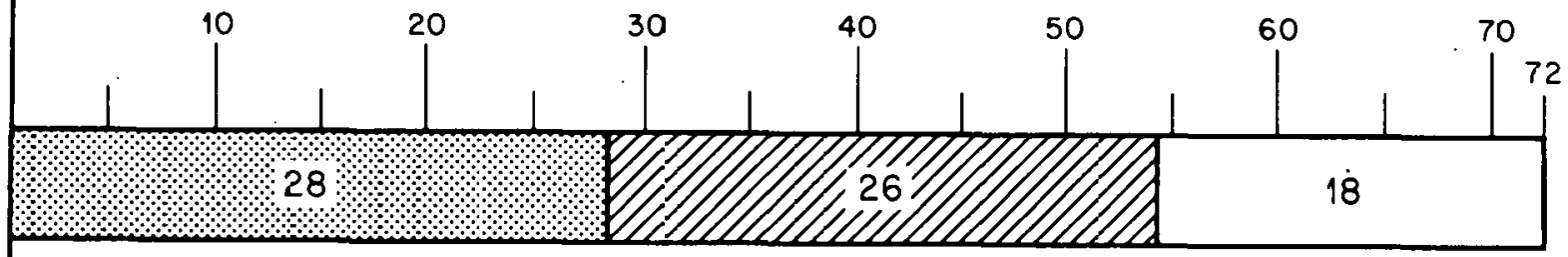

INDUSTRIAL

RESIDENTIAL AND COMMERCIAL TRANSPORTATION

Fig. 3.1. Total U.S. energy consumption and distribution in 1974. 


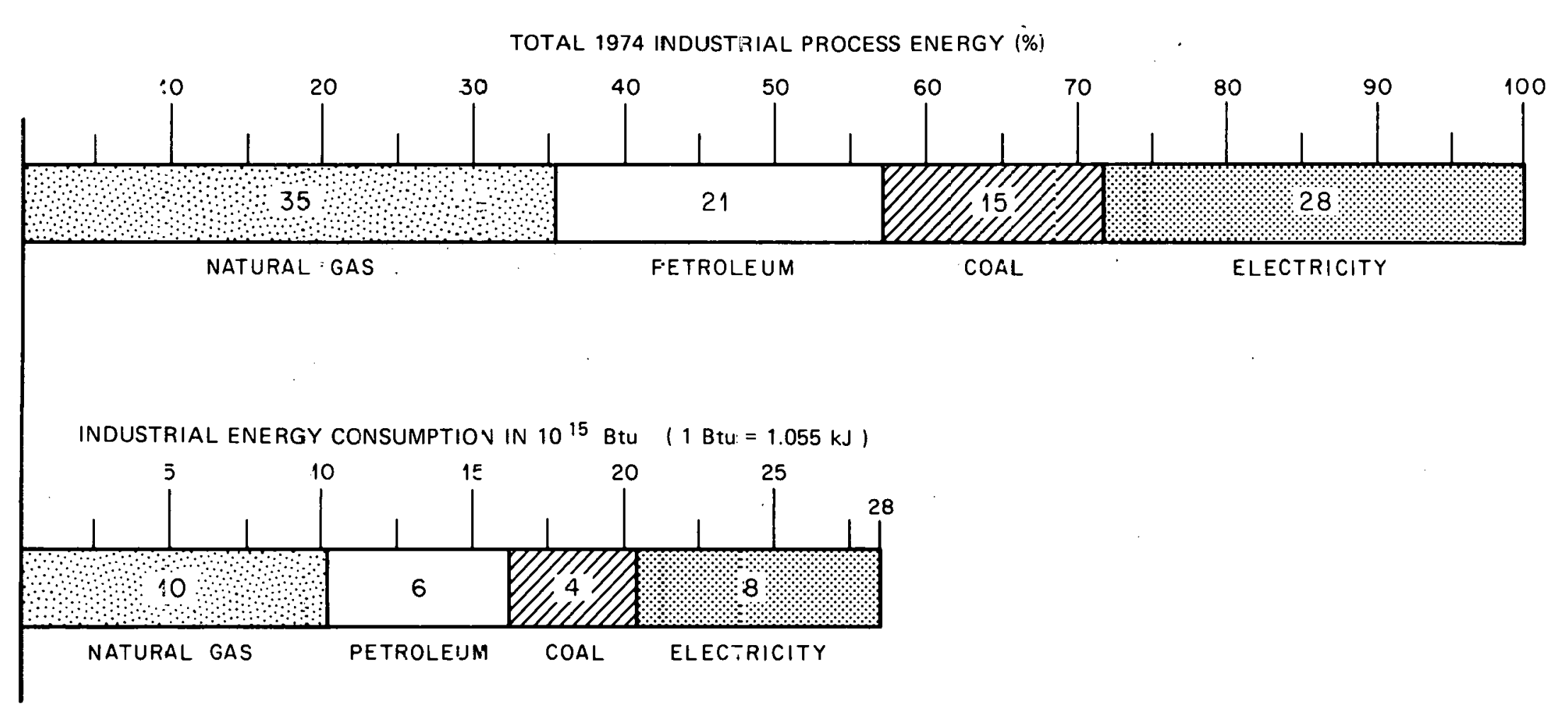

Fig. 3.2. Amount and distribution of source energies in the process industries in 1974 . 
ORNL-DWG 79-4898 ETD

TOTAL 1974 U.S. CONSUMPTION OF NATURAL GAS (\%)

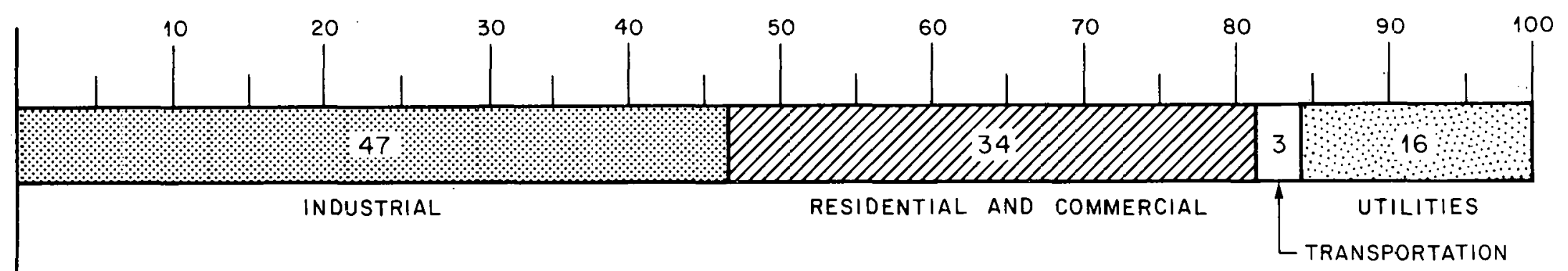

U.S. CONSUMPTION OF NATURAL GAS IN $10^{15}$ Btu $(1 \mathrm{Btu}=1.055 \mathrm{~kJ})$

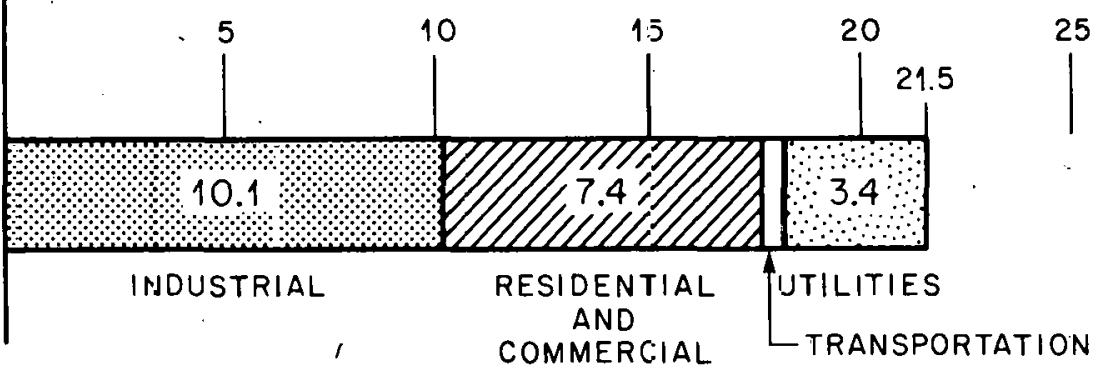

Fig. 3.3. Total U.S. consumption and distribution of natural gas by using sector in 1974 . 


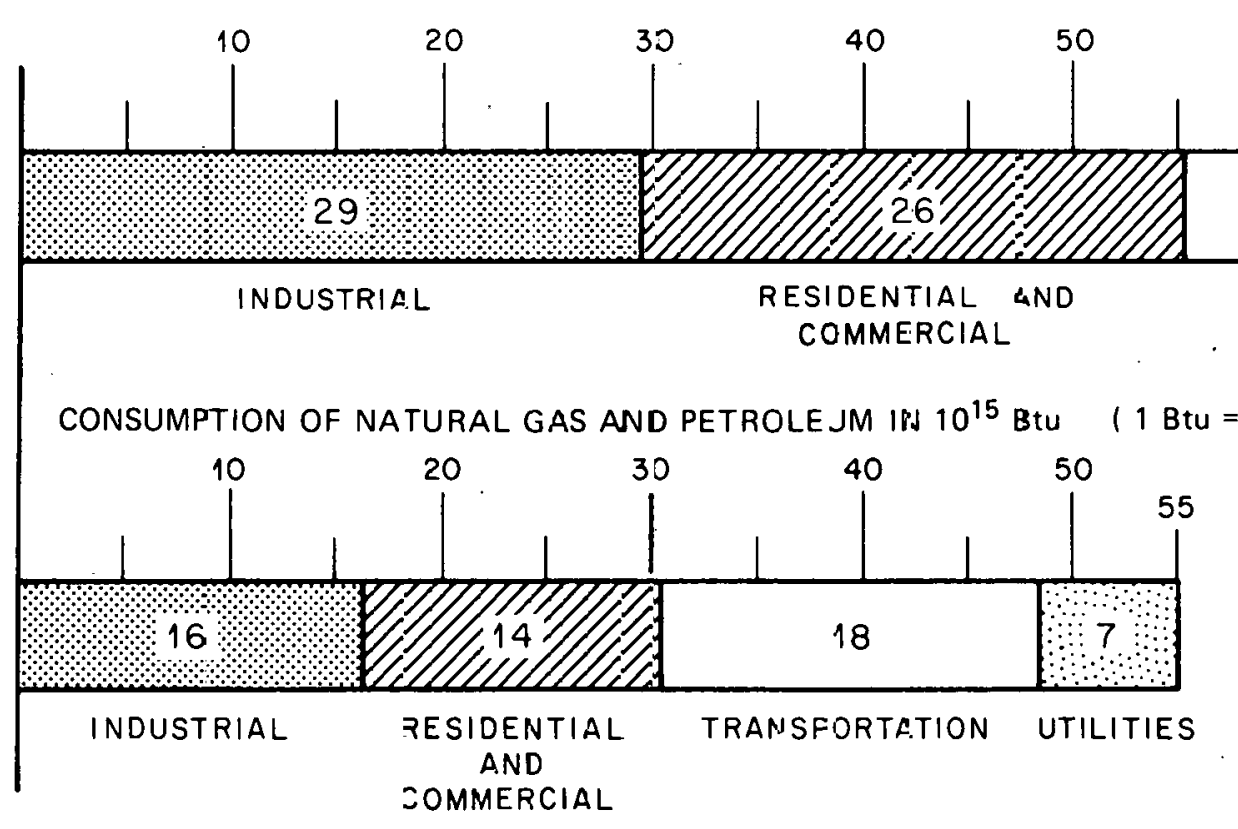

Fig. 3.4. Total U.S. consunption and distribution of natural gas and petroleum by usizg sector in 197 . 
Table 3.1. Distribution by fuel sodrce and use sector of the energy consumed in the United States in 1974 [1015 $\mathrm{kJ}$ (10 15 Btu)]

\begin{tabular}{|c|c|c|c|c|c|c|c|c|}
\hline \multirow{2}{*}{\multicolumn{2}{|c|}{ Sector }} & \multicolumn{4}{|c|}{ Primary enargy source } & \multirow{2}{*}{$\begin{array}{l}\text { Distributed } \\
\text { electricity }\end{array}$} & \multirow{2}{*}{ Total $1^{b}$} & \multirow{2}{*}{$\begin{array}{c}\text { Percent } \\
\text { of U.S. } \\
\text { total }\end{array}$} \\
\hline & & Natural gas & Petroleum & Coa 1 & Nuclear and hydro & & & \\
\hline \multirow[t]{2}{*}{1.} & Residential and commercial & $7.8(7.4)$ & $7.1(6.7)$ & $0.32(0.30)$ & & $3.62(3.43)$ & $27.5(26.1)$ & 35.9 \\
\hline & Percent & 28.4 & 25.6 & 1.2 & & 44.8 & & \\
\hline \multirow[t]{2}{*}{2 . } & Industrial & $10.7(10.1)$ & $6.4(6.1)$ & $4.4(4.2)$ & $<0.1 \quad(<0.1)$ & $8.4(8.0)$ & $30.0(28.4)$ & 39.1 \\
\hline & Percent & 35.5 & 21.5 & $1 \dot{4} .8$ & & 28.2 & & \\
\hline \multirow[t]{3}{*}{3.} & Transportation & $0.63(0.60)$ & $18.4(17.4)$ & $0.01(0.01)$ & · & $0.21(0.20)$ & $19.2(18.2)$ & 25.0 \\
\hline & Percent & 3.5 & 95.2 & & & 1.1 & & \\
\hline & & & & & & $5.84(19.9)$ & & \\
\hline & Electric ${ }^{b}$ utilities & $3.6(3.4)$ & $3.4(3.2)$ & $9.4(8.9)$ & $4.6(4.4 i$ & $21.0(19.9)$ & & \\
\hline & Percænt & 17.1 & 16.1 & $4<.7$ & 22.1 & & & \\
\hline \multirow[t]{3}{*}{5.} & Total by source & $22.7(21.5)$ & $35.2(33.4)$ & $13.8(13.1)$ & $4.6(4.4)$ & & $\underline{-}$ & \\
\hline & U.S. total & & & & & & 72.7 & \\
\hline & Percent of U.S. total & 29.6 & 45.9 & $1 \varepsilon .4$ & 6.1 & & 76.7 & \\
\hline
\end{tabular}

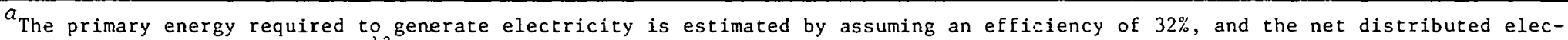
trical energy in 1974 was $1.36 \times 10^{12} \mathrm{kWhr}$.

$b_{\text {Di }}$ ferences in totals obtained by vertical and horizontal summations are the result of rounding.

Souzce: Ref. 1. 


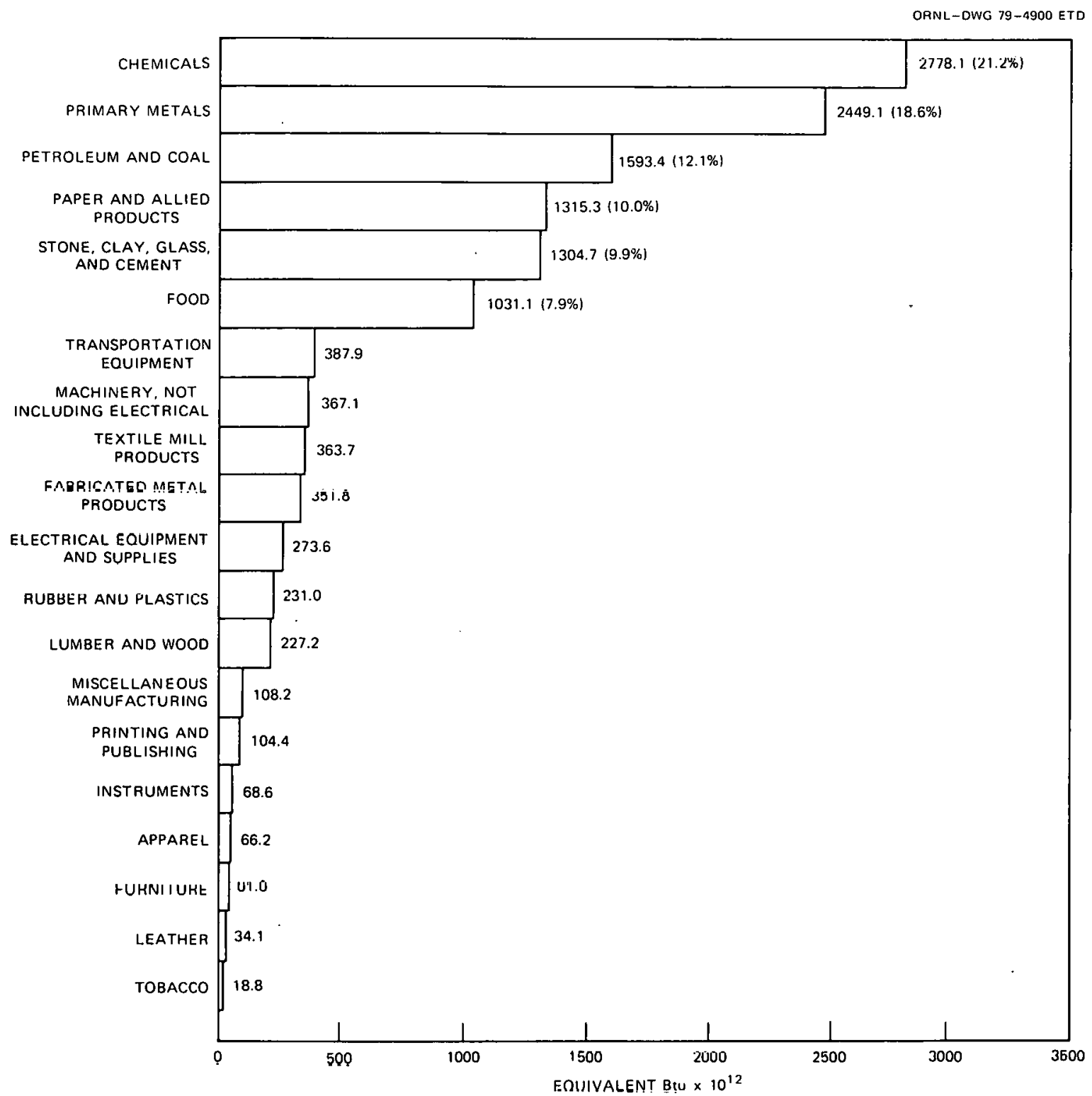

Fig. 3.5. Fuels and electricity purchased by industry in 1971 $(1 \mathrm{Btu}=1.055 \mathrm{~kJ})(\operatorname{Ref} .2)$.

In other words, the fuel energy purchased was used only for heat or power.

Figure 3.6 shows the path of energy consumptions since 1960 based on data ${ }^{1}{ }^{3}$ assembled for the years 1960, 1968, and 1973 through 1975. The dashed lines project the 1973 to 1985 usage based on annual growth rates of 2 and 3\%. The most suitable basis for the projections was 1973 
ORNL-DWG $79-4901$ ETD

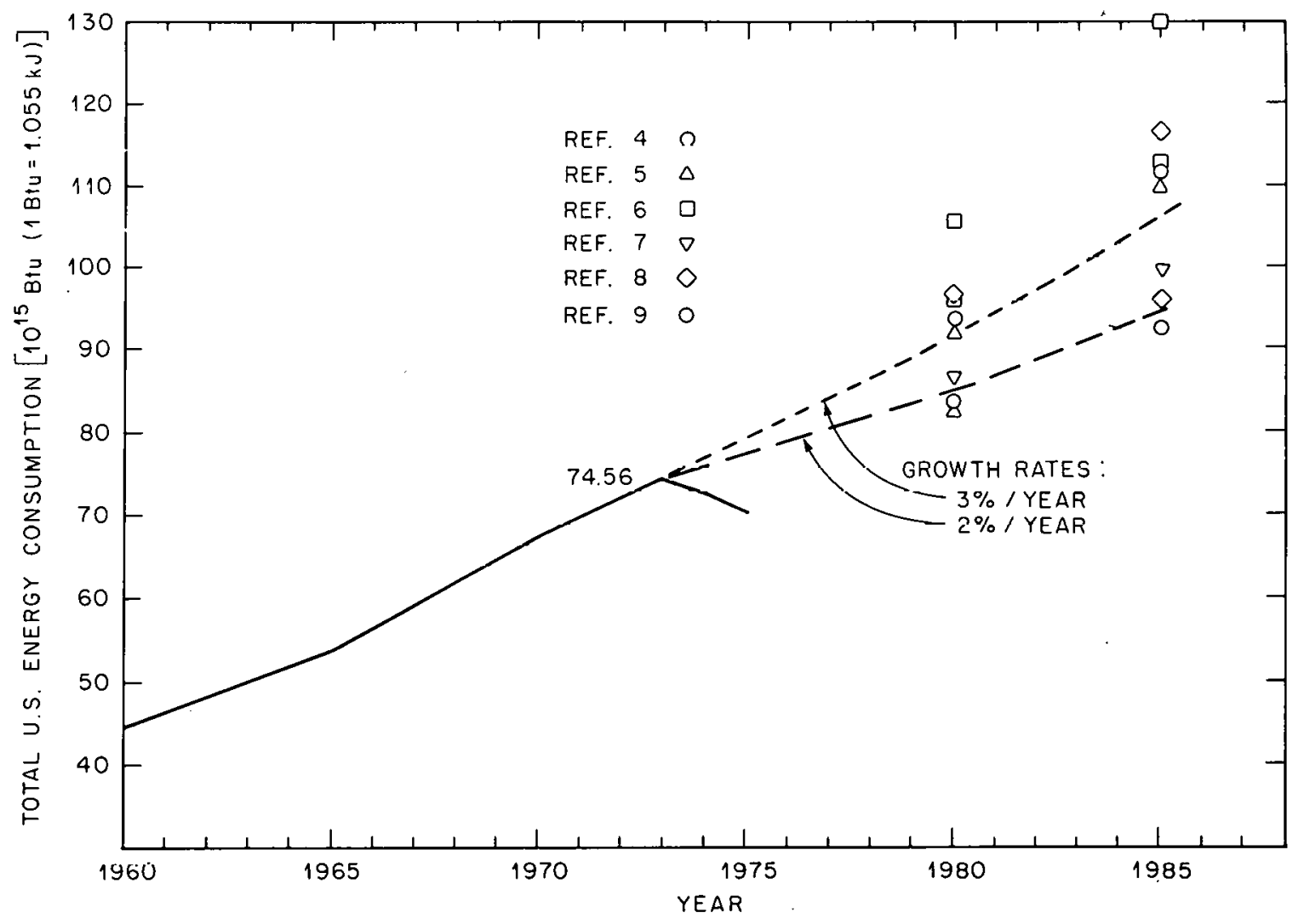

Fig. 3.6. Total U.S. energy consumption since 1960 and forecasts of usages through 1985 .

because the lower usage levels reported for 1974 and 1975 reflect the recent recession - an abnormal disruption of the economy.

The assumption that industrial energy usage will increase at annual rates of 2 to $3 \%$ is arbitrary but not unsupported. To say that accurate energy forecasting is difficult is a gross understatement. Predicted consumptions from different sources vary by substantial amounts, and nearly all these include a large uncertainty band. Williams ${ }^{4}$ reported several forecasts of total U.S. consumption for 1980 and $1985,{ }^{5-9}$ which are also shown in Fig. 3.6. By inspection, an annual growth rate of $3 \%$ is entirely reasonable. The gestation period for a new industrial methodology is usually several years; therefore, estimates of impacts and effects on our energy scenario should take into account escalations in consumption. Table 3.2 shows industrial consumption in 1973 and the projections of 1973 usages escalated under various assumptions to 1985 . 
Table 3.2. 1973 industrial energy consumptions $\left.: 10^{15} \mathrm{~kJ}\left(10^{15} \mathrm{Btu}\right)\right]$ with 1985 estimates of usage $f(r)$ average annual growth rates of 2 and $3 \%$

\begin{tabular}{|c|c|c|c|c|}
\hline \multirow{2}{*}{ Source of energy } & \multirow{2}{*}{1973} & \multicolumn{3}{|c|}{1985} \\
\hline & & $2 \%$, case $1^{a}$ & $3 \%$, case $1^{a}$ & $3 \%$, case $2^{b}$ \\
\hline Natural gas & $11.07(10.49)$ & $11.07(10.49)$ & $11.07(10.49)$ & $15.76 .(14.94)$ \\
\hline Petroleum & $6.75(6.40)$ & $6.75(6.40)$ & $6.75(6.40)$ & $9.64(9.14)$ \\
\hline Coal & $4.61(4 . \equiv 7)$ & $10.63(10.08)$ & $14.16(13.42)$ & $6.57(6.23)$ \\
\hline Distributed electricity & $8.29(7.8 .6)$ & $10.51(9.96)$ & $11.81(11.19)$ & $11.81(11.19)$ \\
\hline Total & $30.71(29.11)$ & $38.95(36.92)$ & $43.8(41.5)$ & $43.8(41.50)$ \\
\hline
\end{tabular}

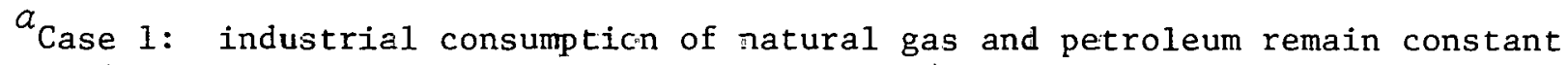
after 1973; electricity usage increases $a=2$ or $3 \% / y e a r$, and the remaining incremental growth requirements are met with cocl.

${ }^{b}$ Case $2:$ consumption rates of all source energy components escalate at $3 \% /$ year. 
Growth rates, by industry, from the OBERS projection* are tabulated in Ref. 10. These rates are forecast for two scenarios: one with and one without energy conservation by the industrial users. The projected rates for the "big six" (chemicals; primary metals; petroleum; paper; stone, clay, and glass; and food) after weighting by the relative usages in Fig. 3.5 indicate total annual increases for the total consumption by these six users through 1985 of 2 and $3 \%$, respectively, for the two scenarios.

A valuable benchmark for visualizing the potential impact of the CCC on energy consumption will be the total energy consumed by the industrial sector. Typical data found in the literature are provided in Table 3.3.

The task is to arrive at the fraction of the benchmark value that could be conserved by the implementation of cogeneration systems with

* Joint study for the Water Resources Council by the Office of Business Economics (OBE) of the U.S. Department of Commerce and the Economic Research Service (ERS) of the U.S. Department of Agriculture.

Table 3.3. Comparison of data for total industrial energy consumption ${ }^{a}$

\begin{tabular}{|c|c|c|c|}
\hline $\begin{array}{c}\text { Total industrial } \\
\text { energy consumption } \\
{\left[10^{15} \mathrm{~kJ}\left(10^{15} \mathrm{Btu}\right)\right]}\end{array}$ & Year & Reference & Remarks \\
\hline $20.95(19.86)$ & 1971 & $11^{b}$ & $\begin{array}{l}\text { Purchased fue } 1 \text { plus purchased elec- } \\
\text { tricity at } 10,500 \mathrm{Btu} / \mathrm{kWhr}\end{array}$ \\
\hline $25.78(24.44)$ & 1971 & 8 & Exclude.s fepedstark \\
\hline $13.86(13.14)$ & 1971 & $2^{b}$ & $\begin{array}{l}\text { Purchased fuel plus purchased elec- } \\
\text { tricity at } 3,413 \mathrm{Btu} / \mathrm{kWhr}\end{array}$ \\
\hline $20.87(19.78)$ & 1971 & $8^{c}$ & Excludes feedstock \\
\hline $\begin{array}{ll}12.00 & (11.37) \\
18.41 & (17.45)\end{array}$ & $\begin{array}{l}1971 \\
1971\end{array}$ & ${ }^{2} c$ & $\begin{array}{l}\text { Purchased fuels only } \\
\text { Excludes feedstock }\end{array}$ \\
\hline $23.86(22.62)$ & 1971 & 8 & $\begin{array}{l}\text { Purchased fuels plus feedstock plus } \\
\text { electricity at } 3,413 \mathrm{Btu} / \mathrm{kWh} \text { ? }\end{array}$ \\
\hline $29.96(28.4)$ & 1974 & 1 & $\begin{array}{l}\text { Purchased fuels plus feedstock plus } \\
\text { electricity at } \mathrm{\omega} 10,500 \mathrm{Btu} / \mathrm{kWh}\end{array}$ \\
\hline $31.23(29.6)$ & 1974 & 12 & Total burden on primary fuel supplies \\
\hline
\end{tabular}


emphasis on oil and gas conservation. The CCC has the realistic potential of using coal to replace a very high percentage of the natural gas and petroleum currently used for process heating. Feedstock fuels and internally derived fuels would not be replaced. The coke utilized in reducing iron ore is, of course, also not displaceable. Therefore, the data compiled by the Bureau of Census for fuels consumed, supplemented by similar data from the Bureau of Mines, are the most satisfactory in determining a conservation impact target for the CCC. The data, broken down by fuel type, are shown in Table 3.4 .

The maximum impact of the $\mathrm{CCC}$ on natural gas and oil consumption can be bracketed by the data presented in Table $3.4: 39$ to $90 \times 10^{6} \mathrm{~m}^{3}$ (245 to $\left.569 \times 10^{6} \mathrm{bbl}\right)$ fuel oil per year and 183 to $268 \times 10^{9} \mathrm{~m}^{3}$ (6454 to $9460 \times 10^{9} \mathrm{ft}^{3}$ ) of natural gas per year. An escalation factor of 2 to $3 \%$ should be applied to estimate the value in years after 1971 . This conservation value does not include the natural gas and petroleum that would be saved by the reduction in generating load at gas- and oil-fired central power stations when the large-scale introduction of cogeneration systems occurs. The disagreement between the Bureau of Census data and the Bureau of Mines data has been noted throughuul 'Llie related literature. ${ }^{11}$ At least one investigation team concluded that the Bureau of Mincs data are more complete. ${ }^{i}$ The 1974 Bureau of Mines data would indicate a target of $263 \times 10^{9} \mathrm{~m}^{3}\left(9300 \times 10^{9} \mathrm{ft}^{3}\right)$ of gas and $101 \times 10^{6} \mathrm{~m}^{3}$ $\left(637 \times 10^{6}\right.$. bb1) of fuel oils per year. ${ }^{12}$ Data for the six major industries to be studied in greater detail in this report are in Table 3.5.

All the industrial perroleum and llalural gas cuuld be replaced only hypothetically by the coal combustor. The amounts of energy, and subsequently the amounts of natural gas and petroleum, used for process heating that can actually be displaced by coal combustion cogeneration units must be determined.

\subsection{U1timate Use of Energy Purchased by Industry}

The potential impact and applicability of the CCC are partially determined by (1) energy form(s) required by the process (electricity, 
Table 3.4. Estimated fuel consumption for heat and power ${ }^{a}$ in 1971 by fuel type

\begin{tabular}{|c|c|c|c|c|c|c|c|c|c|}
\hline Fuel :ype & Quantity ${ }^{b}$ & {$\left[10^{12}\right.$} & $\begin{array}{l}\text { Energy }^{b} \\
\text { kJ }\left(10^{12}\right.\end{array}$ & Btu)] & Quantity ${ }^{b}$ & {$\left[10^{12}\right.$} & $\begin{array}{l}\text { Ene } \\
\mathrm{kJ}\end{array}$ & $\begin{array}{l}\mathrm{rgy}^{c} \\
\left(10^{12}\right.\end{array}$ & Btu)] \\
\hline Fuel oils, $\mathrm{m}^{3}(\mathrm{~b} \supset 1)$ & $39.1 \times 10^{6}\left(245.6 \times 10^{6}\right)$ & & $1578(1496)$ & & $90.5 \times 10^{6}\left(569 \times 10^{6}\right)$ & \multicolumn{4}{|c|}{$3,548(3363)$} \\
\hline Natural gas, $\mathrm{m}^{3}\left(\mathrm{ft}^{3}\right)$ & $183=10^{9}\left(6454 \times 10^{9}\right)$ & & $1047(6680)$ & & $258 \times 10^{9}\left(9460 \times 10^{9}\right)$ & \multicolumn{4}{|c|}{$10,290(9753)$} \\
\hline Coal - coke, metric tons (tons) & $68 \times 10^{6}\left(75 \times 10^{6}\right)$ & & $2066(1958)$ & & $144 \times 10^{6}\left(1.59 \times 10^{6}\right)$ & \multicolumn{4}{|c|}{$4,570(4332)$} \\
\hline
\end{tabular}

$a_{\text {Nonfuel uses ex } z 1 \text { uded. }}$

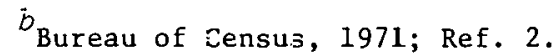

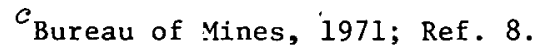


Table 3.5. Purchased fuel consumption by the si= major industries ${ }^{a}$

\begin{tabular}{|c|c|c|c|c|c|c|c|}
\hline Fuel type & $\begin{array}{l}\text { Iron/steel } \\
\text { SIC } 331,332\end{array}$ & $\begin{array}{l}\text { Petroleum } \\
\text { SIC } 29\end{array}$ & $\begin{array}{l}\text { Themicals } \\
\text { SIC } 28\end{array}$ & $\begin{array}{l}\text { Stone/glass } \\
\text { SIC } 32\end{array}$ & $\begin{array}{l}\text { Paper/pulp } \\
\text { SIC } 26\end{array}$ & $\begin{array}{l}\text { Food } \\
\text { SIC } 20\end{array}$ & Total \\
\hline $\begin{array}{l}\text { Distillate oil } \\
10^{6} \mathrm{~m}^{3}\left(10^{5} \mathrm{bbl}\right) \\
10^{12} \mathrm{~kJ}\left(11^{12} \mathrm{Btu}\right)\end{array}$ & $\begin{array}{l}1.94(12.2) \\
75.0(71.1)\end{array}$ & $\begin{array}{l}: \\
0.51(3.2) \\
19.6(18.6)\end{array}$ & $\begin{array}{l}2.3 \equiv(14.8) \\
90.5(86.2)\end{array}$ & $\begin{array}{l}1.7611 .1 ! \\
68.3: 64.7 !\end{array}$ & $\begin{array}{l}2.88(18.1) \\
111.2(105.4)\end{array}$ & $\begin{array}{l}1.73(10.9) \\
67.0(63.5)\end{array}$ & $\begin{array}{l}11.18(70.3) \\
432.1(409.6)\end{array}$ \\
\hline $\begin{array}{l}\text { Residual oil } \\
10^{6} \mathrm{~m}^{3}\left(10^{6} \mathrm{bb} 1\right) \\
10^{12^{2}} \mathrm{~kJ}\left(10^{12} \mathrm{Bcu}\right)\end{array}$ & $\begin{array}{l}2.70(17.0) \\
112.8(106.9)\end{array}$ & $\begin{array}{l}1.70(10.7) \\
71.0(67.3)\end{array}$ & $\begin{array}{l}3.04(19.1) \\
126.7(120.1)\end{array}$ & $\begin{array}{l}1.34 \quad 8.4) \\
55.7 \quad 52.8 !\end{array}$ & $\begin{array}{l}7.39(46.5) \\
308.4(292.3)\end{array}$ & $\begin{array}{l}1.57(9.9) \\
65.6(62.2)\end{array}$ & $\begin{array}{l}17.74(111.6) \\
740.2(701.6)\end{array}$ \\
\hline $\begin{array}{l}\text { Coal }- \text { coke } \\
10^{6} \text { metric ton }\left(10^{6} \text { ton: }\right. \\
10^{12} \mathrm{~kJ}\left(10^{12} \mathrm{Btu}\right)\end{array}$ & $\begin{array}{l}17.25(19.0) \\
523.4(496.1)\end{array}$ & $\begin{array}{l}0.33(0.36) \\
9.9(9.4)\end{array}$ & $\begin{array}{l}16.7(18.4) \\
506.8(480.4)\end{array}$ & $\begin{array}{l}8.9(9.8) \\
270.0(255.9)\end{array}$ & $\begin{array}{l}8.6(9.5) \\
261.6(248.0)\end{array}$ & $\begin{array}{l}4.1(4.5) \\
124.0(117.5)\end{array}$ & $\begin{array}{l}55.8(61.5) \\
1694.0(1605.7)\end{array}$ \\
\hline $\begin{array}{l}\text { Natural gas } \\
10^{9} \mathrm{~m}^{3}\left(10^{9} \mathrm{ft}^{3}\right) \\
10^{12} \mathrm{~kJ}\left(10^{12} \mathrm{Btu}\right)\end{array}$ & $\begin{array}{l}20.4(720) \\
786.3(745.3)\end{array}$ & $\begin{array}{l}37.4(1322) \\
1443.8(1368.5:\end{array}$ & $\begin{array}{l}40.4(1427) \\
1552.2(1477.0)\end{array}$ & $\begin{array}{l}19.9 \cdot(704) \\
768.8(728.7)\end{array}$ & $\begin{array}{l}13.5(477) \\
520.9(493.7)\end{array}$ & $\begin{array}{l}13.6(479) \\
523.1(495.8)\end{array}$ & $\begin{array}{ll}145.15 & (5129) \\
5601.3 & (5309.3)\end{array}$ \\
\hline
\end{tabular}

a Data avallable from 1971, Bureau of Cinsus, includes fiels used as fuel only. 
direct heat, steam) and (2) process temperatures. This section deals primarily with item 1 , with the ultimate purpose of developing an estimate for energy, oil, and natural gas used for industrial process heating.

A recent estimate of the fractional distribution by form of the energy consumed by industry is listed in Table 3.6. This tabulation is based on the more detailed breakdown in Table 3.7 . The higher (48\%) value for 1976 in Table 3.7 is assumed to include energy used for steam that is used in cogeneration systems and is not entirely available as process energy. However, these figures have come under recent criticism for a lack of real basis. ${ }^{3}$ Note that the fraction of electric power is markedly higher than that cited in other references. ${ }^{2}, 12$ Furthermore, the aggregation of process heat data from individual industries has been expressed as the most accurate method for arriving at such percentages. This can hardly be argued, but the magnitude of the described task is frightening if applied to all manufacturers. Thus the six major consumers have received the greatest attention.

Table 3.6. Estimated fractional distribution by energy form of the total industrial energy consumed in the United States

\begin{tabular}{lc}
\hline Energy form & Distribution (\%) \\
\hline Process steam & 40 \\
Direct heat & 30 \\
Electricity & 20 \\
Other $^{\alpha}$ & 10 \\
\hline \multicolumn{1}{c}{$a_{\text {Includes feedstocks and uncer- }}$} \\
tainties.
\end{tabular}

\subsection{Energy Consumption for Process Heat}

Special attention is given here to the six major industries under close inspection. For determining the market and impact of the coal cogeneration system, the fraction of the total energy consumption delegated to process heating must be identified. An effort was made to exclude energy (fuel) consumption associated with raw materials because 
Table 3.7. End-use energy distribution in industrial processes

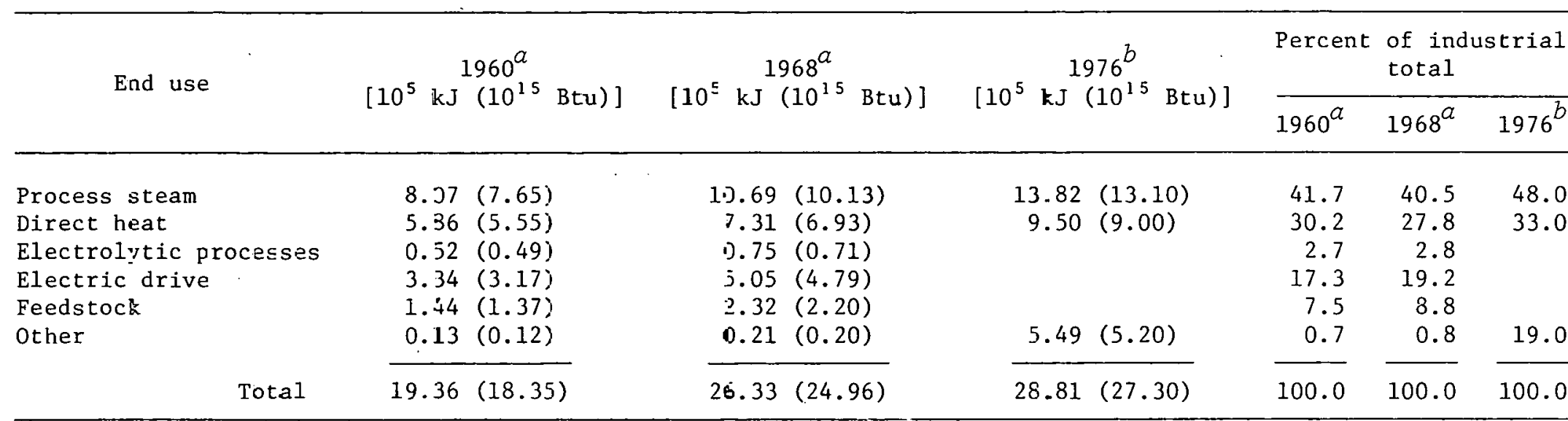

$a_{\text {Reference } 3 .}$

$b_{\text {Reference } 14 .}$ 
this is not actually used for process heating and also because it cannot be replaced by a new source'without altering the industrial process. The data compiled from numerous sources are presented in Table 3.8. The potential for fuel conversion in process steam generators and heaters is somewhat lower than might be expected because of industrial efforts to make use of by-product fuels and waste heat recovery. For example, over $40 \%$ of the steel-making process heat is supplied by blast furnace gases and coke gases. ${ }^{15}$ By-product wood waste and pulping liquors provide about $50 \%$ of the process heating needs in the paper/pulp industry. ${ }^{15}$ Furthermore, heat recovery systems are prevalent in petroleum and other industries. Note that over $35 \%$ of the energy consumption in the chemicals group is as feedstock. ${ }^{19}$ The second data set in Table 3.8 is intended only to present comparative data from different sources.

Because of the influence of by-product fuels, the potential conservation of oil and gas is best derived by referring again to the Bureau of Census data on fuels consumed for heat and power. The necessary information is the quantity of oil and gas used specifically for process heating. The fractions of oil and gas used for heating are given in Table 3.9 (Ref. 20). The data can be partially confirmed by referring to the Bureau of Census information on internally generated electricity, which, after eliminating feedstocks, is the only other significant end use of oil and gas aside from process heat. Applying a typical value of $92 \%$ to the oil and gas consumption in Table 3.4, we arrive at estimates for the annual consumption of oil and gas for process heating. From data presented in Ref. $20,250 \%$ of the oil and gas i.s used for direct heat and the other $50 \%$ for generating steam. The estimates are listed in Table 3.10. In addition to potential savings of process heat fuel, coal-fired cogeneration systems would have substantial impact on the oil and gas consumption at central power stations. About $35 \%$ of the utility electricity in the United States is generated from fuel oil (18\%) and natural gas (17\%). ${ }^{12}$ Furthermore, the industrial sector consumes $242 \%$ of the utility electricity generated. ${ }^{12}$ In terms of fuel value; industry accounts for $\sim 3003 \times 10^{12} \mathrm{~kJ}\left(2846 \times 10^{12} \mathrm{Btu}\right)$ of the oil and gas consumed by the utilities. If the entire industrial electrical load $\left(781 \times 10^{9} \mathrm{kWhr}\right)^{12}$ were generated by cogeneration systems operating at 
Table 3.8. Process heat energy consuned in six major industries (fron varions references)

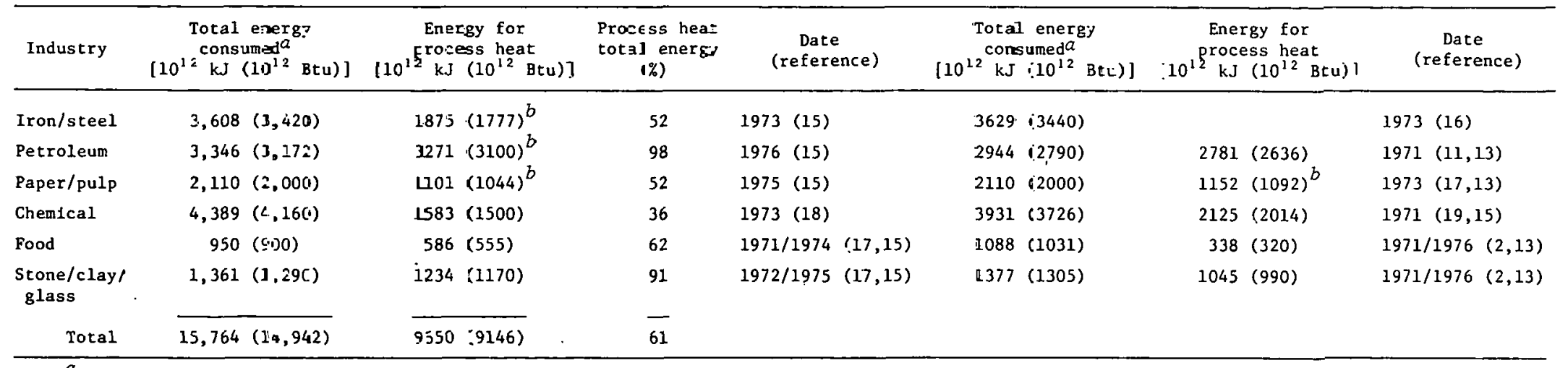

${ }^{a}$ Includes feedstock and internally gerezated fuels; electricity conversion is $3413 \mathrm{Btu}=1 \mathrm{kWhr}$.

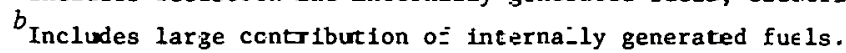


Table 3.9. Ultimate use of oil and gas used as fuel in five major industries $a$

\begin{tabular}{lcc}
\hline Industry & $\begin{array}{c}\text { Oil and gas, } \\
\text { percent of } \\
\text { total fuels }\end{array}$ & $\begin{array}{r}\text { Oil and gas } \\
\text { used for heat } \\
(\%)\end{array}$ \\
\hline Primary metals & 38 & 89 \\
Petroleum & 52 & 93 \\
Chemicals & 75 & 93 \\
Paper/pulp & 46 & 92 \\
Stone/clay/glass & 74 & 98 \\
\hline \multicolumn{2}{c}{ a 1971 data primarily. Food industry data } \\
not available. \\
b Includes Bureau of Census fuels plus in- \\
dustry data on self-generated fuels. \\
Source: Ref. 20.
\end{tabular}

Table 3.10. Estimated annual oil and gas consumption for industrial process heating

\begin{tabular}{|c|c|}
\hline Fue1 & Consumption \\
\hline $\begin{array}{l}\text { Oils, } 10^{6} \mathrm{~m}^{3}\left(10^{6} \mathrm{bbl}\right)^{a} \\
\text { Oils, } 10^{12} \mathrm{~kJ}\left(10^{12} \mathrm{Btu}\right) \\
\text { Gas, } 10^{9} \mathrm{~m}^{3}\left(10^{9} \mathrm{ft}^{3}\right)^{b} \\
\text { Gas, } 10^{12} \mathrm{~kJ}\left(10^{12} \mathrm{Btu}\right)\end{array}$ & $\begin{array}{l}36 \text { to } 83(225 \text { to } 523) \\
1451 \text { to } 3264 \text { (1376 to } 3094) \\
168 \text { to } 246(5937 \text { to } 8703) \\
6482 \text { to } 9467(6145 \text { to } 8973)\end{array}$ \\
\hline $\begin{array}{l}{ }_{\text {About } 53 \% \text { of indust }} \\
\text { U.S. oil consumption. } \\
b_{\text {About } 86 \% \text { of indust }} \\
\text { U.S. gas consumption. }\end{array}$ & $\begin{array}{l}1 \text { oil consumption, } 9 \% \text { of } \\
\text { gas consumption, } 40 \% \text { of }\end{array}$ \\
\hline
\end{tabular}

a iujlest $60 \%$ cfficiency, the energy savings would be $44009 \times 10^{12} \mathrm{~kJ}$ $\left(3800 \times 10^{12} \mathrm{Btu}\right)$ per year.

The data presented in this section, although perhaps appearing to be rather incongruent, can logically be put into perspective as in Fig. 3.7. The target for industrial conversion to coal is evidently a 
TOTAL U.S. ENERGY CONSUMPTION (\%)

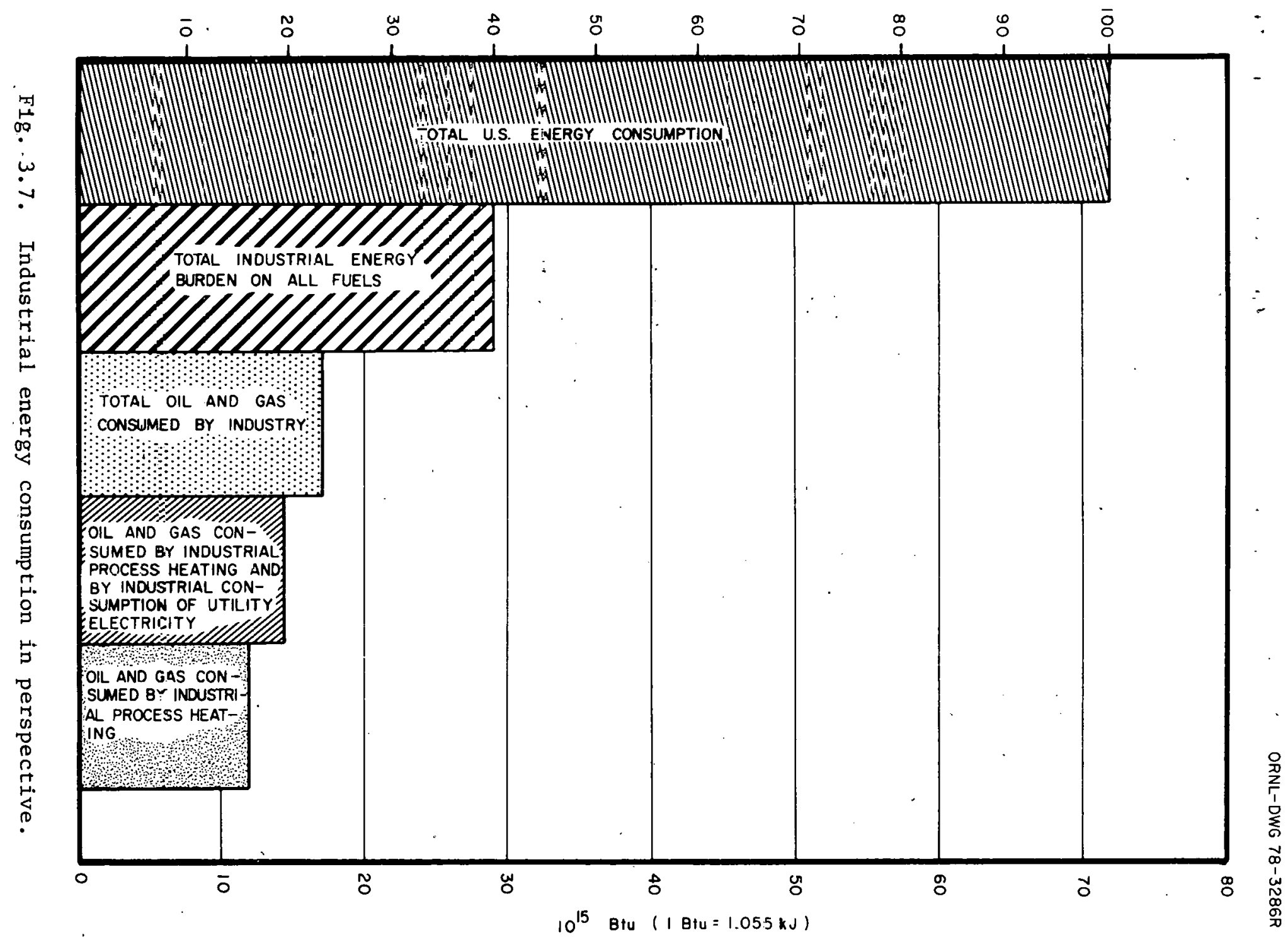


significant fraction ( $>15 \%$ ) of the total U.S. fuel energy demand. The potential energy savings from cogeneration of elèctricity are also noteworthy at $25 \%$ of the national energy consumption.

\section{References}

1. Federal Energy Administration, National Energy Information Center, Monthly Energy Review, Washington, D.C. (March 1976).

2. U.S. Bureau of the Census, Census of Manufacturers, 1972, Special Report Series: Fuels and Electric Energy Consumed, MC72 (SR)-6, U.S. Government Printing Office, Washington, D.C., 1973.

3. Office of Science and Technology, Patterns of Energy Consumption in the United States, Washington, D.C. (January 1972).

4. L. J. Williams, A Preliminary Forecast of Energy Consumption Through 1985, EPRI-SR-37, Electric Power Research Institute (March 1976).

5. Federal Energy Administration, Project Independence Report (November 1974).

6. National Petroleum Council, U.S. Energy Outzook: A Summary Report of the National Petroleum Council (December 1972).

7. Intertechnology Corporation, The U.S. Energy Problem (November 1971).

8. W. G. Dupree and J. A. West, U.S. Energy Through the Year 2000, U.S. Department of the Interior (December 1972).

9. A Time to Choose, Energy Policy Project of the Ford Foundation, 1974.

10. M. H. Farmer, E. M. Magee, and F. M. Spooner, Application of Fluidized-Bed Technology to Industrial Boilers, Exxon Research and Engineering Company, Linden, N.J. (January 1977).

11. J. G. Myers et a1., Conference Board, Energy Consumption in Manufacturing, Ballinger Publishing Company, Cambridge, Mass., 1974.

12. W. G. Dupree and J. S. Corsentino, U.S. Energy I'hrough the Year' 2000 (Revised), U.S. Department of the Interior (December 1975).

13. Intertechnology Corporation, Analysis of the Economic Potential of Sol.ar Thermal Energy to Provide Industrial Process Heat, Vol. 1, Fina1 Report, Report 00028-1 (NTIS-C002829/1) (February 1977).

14. Resource Planning Associates, Inc., The Potential for Cogeneration Development in Six Major Industries by 1985, Draft Final Report, Cambridge, Mass. (September 1977).

15. Sumey of the Applications of Solar Thermal Energy Systems to Industrial Process Heat, Volume 2 - Industrial Process Heat Survey, TID 27348/2, Battelle Laboratories (January 1977). 
16. Federal Energy Administration, The Data Base - The Potential for Energy Conservation in Nine Selected Industries, Volume 6 - Stecl, Conservation Paper No. 14, Office of Industrial Programs, 1975.

17. Dow Chemical Company, Energy Consumption: Paper, Stone/CZay/Glass/ Concrete, and Food Industries, EPA-650/2-75-032.c (Apri1 1975).

18. J. T. Reding and B. P. Shepherd, Erergy Consumption: F'uel Utilization and Conservation in Industry, EPA-650/2-75-032.d, Dow Chemical Company, Freeport, Tex. (August 1975).

19. International Research and Technology Corporation, Industrial Energy Study of the Industrial Chemicals Group, IRT-342-R (PB-236322) (August 1974).

20. Dow Chemical Company, Evaluation of New Energy Sources for Process Heat, NSF-OEP74-18055-1 (PB-245604), Midland, Mich. (September 1975). 


\section{FEASIBILITY OF COGENERATION SYSTEMS FOR GENERATING INDUSTRIAL HEAT AND POWER}

The first test of the feasibility of a cogeneration system to efficiently generate a manufacturing plant's electricity, steam, and direct heat requirements is primarily a question of thermodynamics. Any cogeneration system that produces power through a thermodynamic cycle can be represented schematically, as in Fig. 4.1. The following oversimplified statements are useful in characterizing the system.

1. The electricity output is larger for large $\mathrm{T}_{2}-\mathrm{T}_{3}$ ( $\mathrm{T}$ representing temperature).

2. Electricity $=Q_{1}-Q_{2}(Q$ representing heat transfer).

3. Useful thermal energy $=Q_{2}-Q_{3}$,

$$
=Q_{1}-\text { electricity }-Q_{3} \text {. }
$$

4. Overall efficiency $=\frac{\text { electricity }+ \text { useful thermal energy }}{Q_{1}}$.

The following conclusions may be drawn from these statements.

1. For high electricity output, the useful thermal energy available will be relatively small, and vice versa.

ORNL-DWG 78-3292R

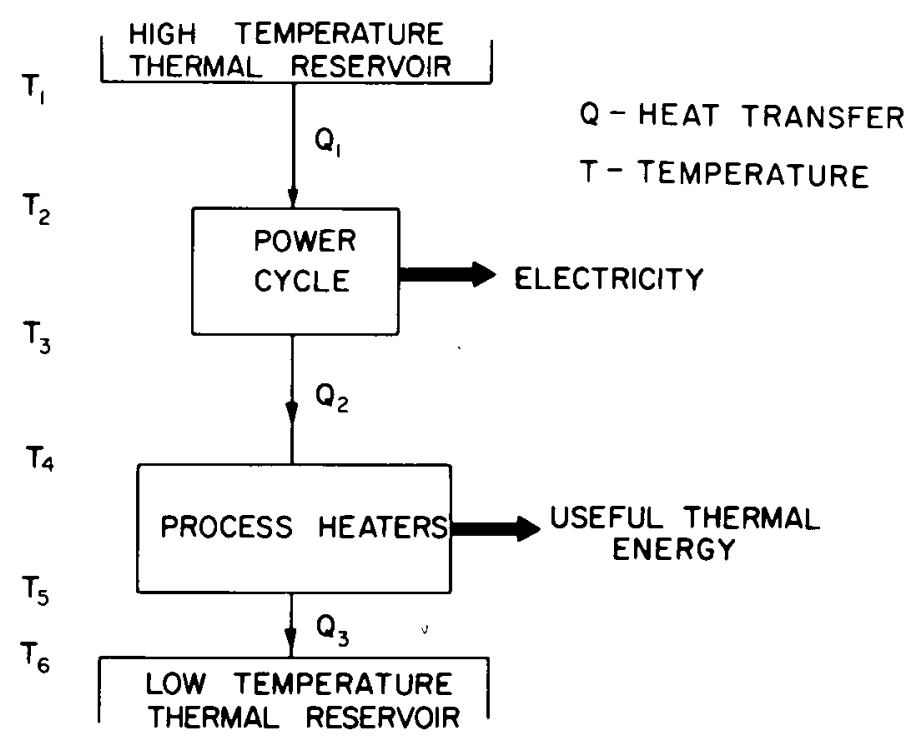

Fig. 4.1. Schematic of cogeneration system. 
2. For high-temperature thermal energy plus electricity, $\mathrm{T}_{2}$ must be high (peak temperature of power cycle).

3. For high overall efficiency, $Q_{3}$ must be small, that is, $T_{5}$ must be as close to $\mathrm{T}_{6}$ as practical.

In relation to these concepts, the performance and capabilities of real systems can be adequately described by their respective heat/power ratios and useful heat delivery temperature. The potential conservation impact of a cogeneration system depends on whether the heat/power ratio and process heat temperature demand at an industrial site can be satisfied by the particular system.

\subsection{Cogeneration Prime Mover Characteristics}

The cogeneration capabilities of three types of power plants are compared in Fig. 4.2. Compression ignition (CI) and spark ignition (SI) internal combustion (IC) engines presently offer the highest electrical output per unit of fuel comsumption. With reference to Fig. 4.1, one reason for this is that the peak temperature $\left(T_{2}\right)$ permitted in the intermittently firing internal combustion engines is much higher than that allowable in the continuous operation of gas or steam turbines. A typical IC-engine cogeneration system is illustrated in Fig. 4.3.

The data for the IC engine in Fig. 4.2 is representative of typical CI and SI models.' The useful heat delivery temperature shown is that of the exhaust gases. However, about one-third of the heat value is in the cooling water at a temperature of $\sim 110^{\circ} \mathrm{C}\left(230^{\circ} \mathrm{F}\right)$; thus the combined useful heat temperature would be less than that shown. The IC engine, with ils hlyh electrical output, also offers a relatively low capital cost and would have some important cogeneration applications. However, the IC engine unfortunately possesees the terminntive characteristics of being unable to operate with coal as a fuel. Coal liquefaction or gasification would be prerequisite to its wide use in cogeneration.

Steam turbines are already used to some extent to provide either shaft power or electricity in industries where large quantities of process steam are generated. The data generated for Fig. 4.2 apply to a back-pressure turbine with varying feedwater and condensate return 


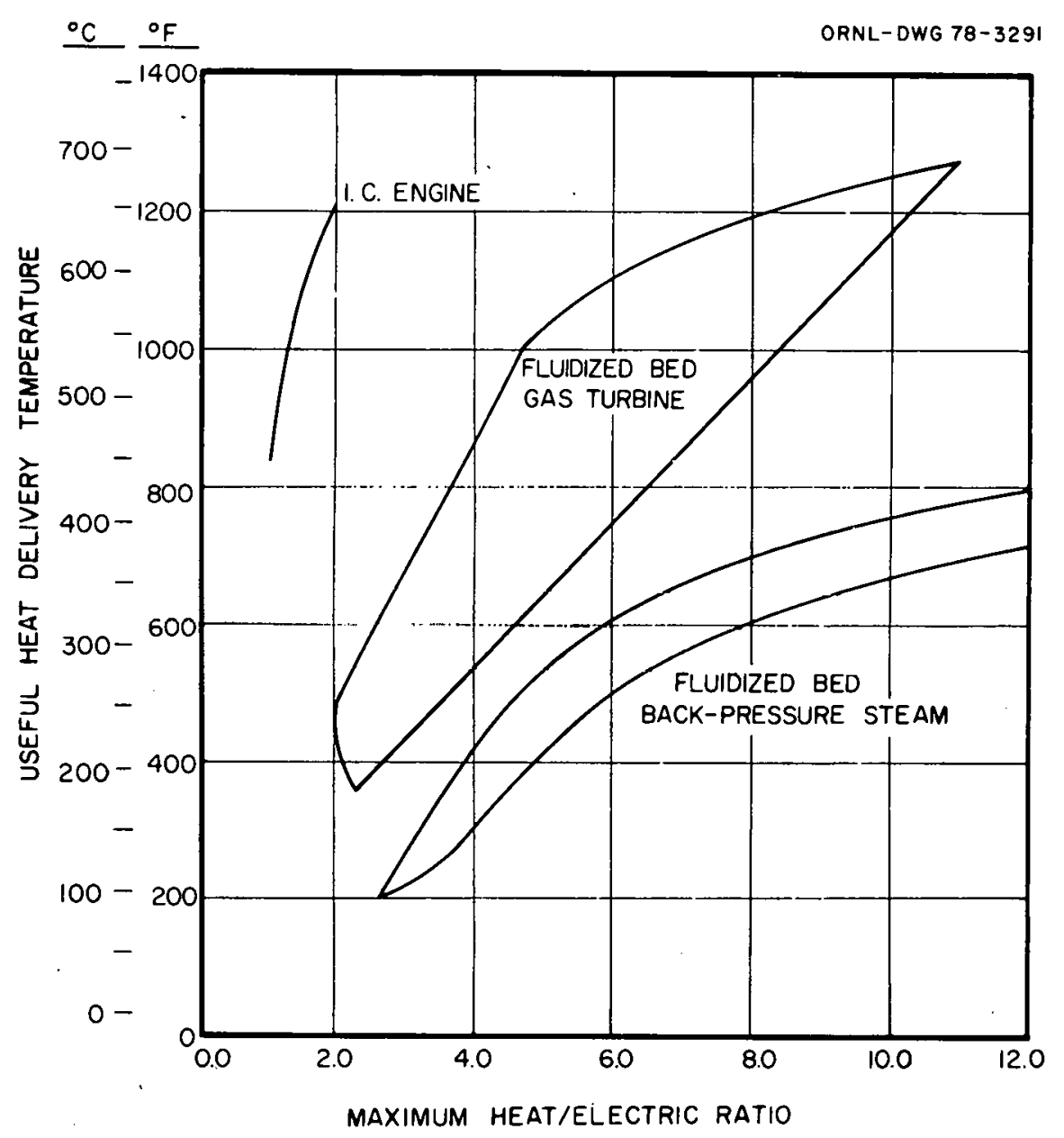

Fig. 4.2. Comparison of cogeneration capabilities of different prime movers.

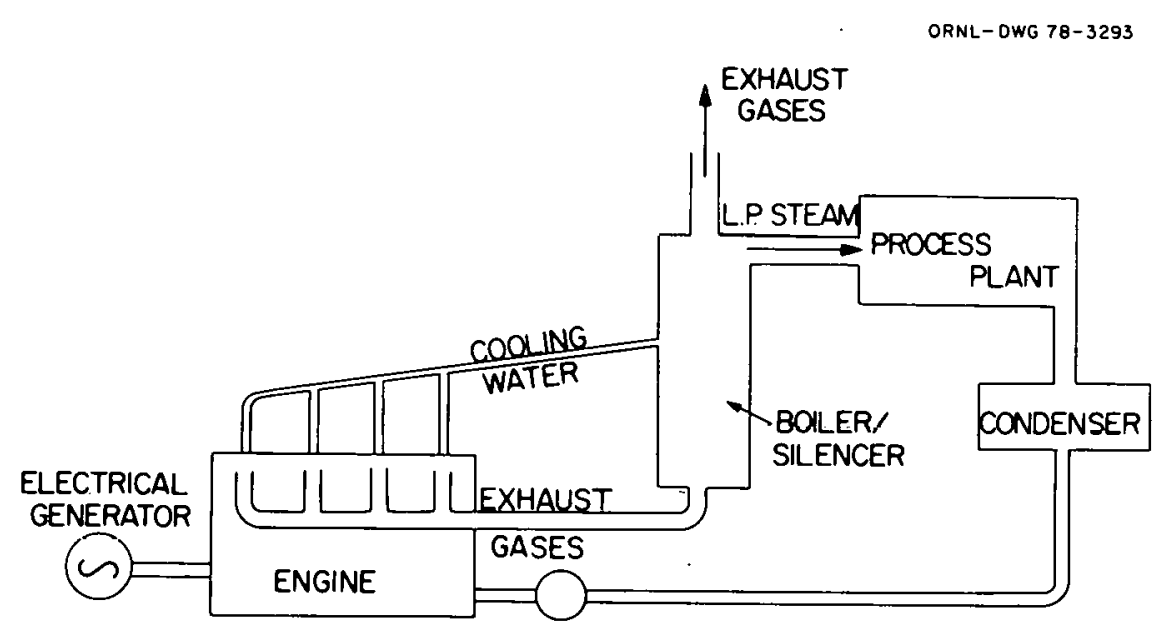

Fig. 4.3. A reciprocating IC-engine system (Ref. 1). 
temperatures. Systems where most of the condensate is returned to the boiler feed offer high overall efficiency. A back-pressure turbine cogeneration schematic is shown in Fig. 4.4. This type of system is generally employed when the steam energy required is rather large in comparison to the electric demand. ${ }^{2}$

Other conventional steam cogeneration systems include the condensing-turbine system and the extraction steam-turbine system.

The condensing system is applicable only in cases where the temperature requirements for heat are very low. Steam extraction systems, on the other hand, are capable of supplying high-temperature steam in small amounts.

The significant advantages that have been identifled for steamturbine systems include (1) multifuel capability, (2) a wide range of available equipment, and (3) reliability.

As evident from Fig. 4.2, the major shortcoming of the steam systems is their inability to generate high-temperature useful heat in addition to significant electric power; for example, at a heat/power ratio of $4: 1$. Referring again to Fig. 4.1, the underlying reason is that $T_{2}$ io not high eiuough. The cumpallbll1cy of conventional materials with high-temperature steam limits the peak cycle temperature to $2538^{\circ} \mathrm{C}$ $\left(1000^{n} \mathrm{~F}\right)$.

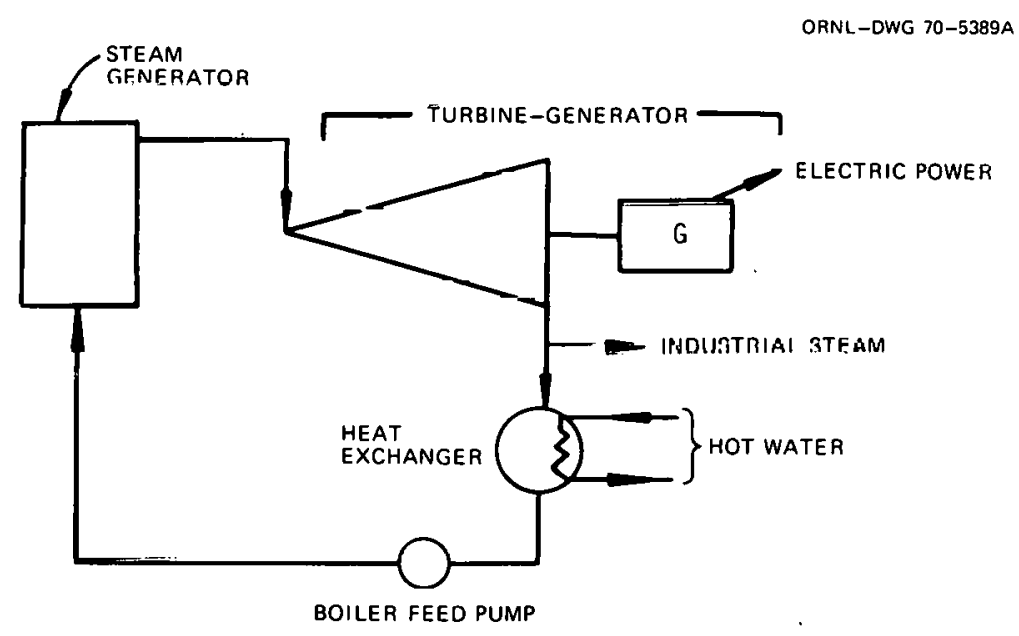

Fig. 4.4. Back-pressure turbine system for producing process steam and hot water. 
The fluidized-bed gas turbine system shown in Fig. 4.5 is characterized by a combination of the better qualities of the IC engine and the steam turbine identified previously. The version of the system with a recuperator is capable of generating electricity sufficient for a heat/electric ratio of 3 , while still delivering hot air to a direct heater or waste heat boiler at $2360^{\circ} \mathrm{C}\left(680^{\circ} \mathrm{F}\right)$. The turbine inlet temperature of $816^{\circ} \mathrm{C}\left(1500^{\circ} \mathrm{F}\right)$ is primarily responsible for the obvious advantage over steam system performance. This characteristic of gas turbines is not new, because they have been cited as potential cogeneration candidates elsewhere. ${ }^{3,4}$ However, the capacity for this particular system to burn coal is innovative and magnifies its attractiveness.

The overall fuel efficiencies for the systems of Fig. 4.2 are about 82 to $85 \%$ for the steam and CCC, with the IC engine being slightly lower. In generating the data (except for the case of the steam turbine condensing at high pressure), the assumption was made that the working fluid heat could be utilized down to $38^{\circ} \mathrm{C}\left(100^{\circ} \mathrm{F}\right), \mathrm{T}_{5}$ in Fig. 4.1. In some

ORNL-DWG 78-3285R

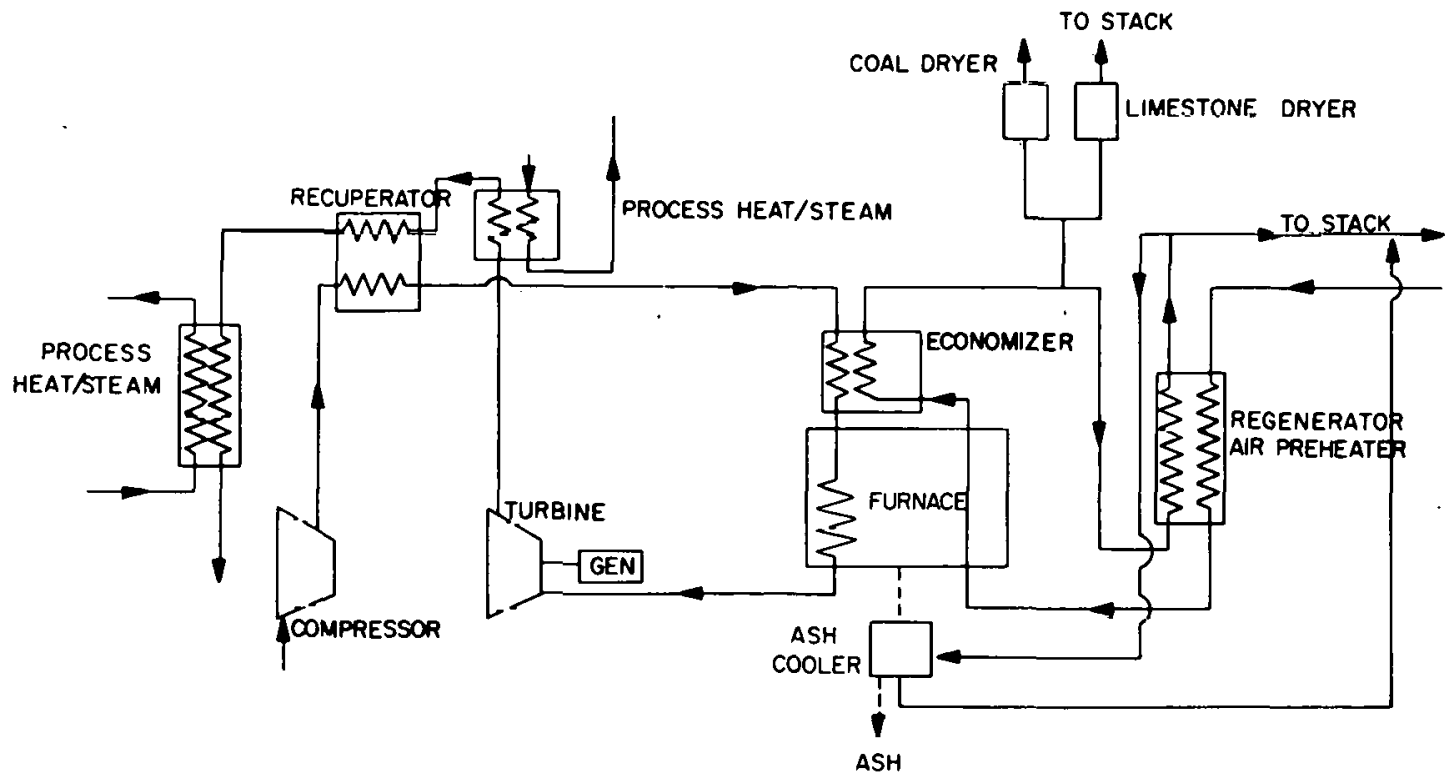

Fig. 4.5. Atmospheric fluidized-bed coal-combustion gas-turbine cogeneratiun system. 
applications, this may not be possible. In other cases, if the economics were favorable, a higher working fluid flow could be specified to increase the electric power, raising $\mathrm{T}_{5}$ and sacrificing overall fuel utilization. The relations between the thermal rejection temperature ( $T_{5}$ in Fig. 4.1), heat/power ratio, and useful heat temperature are depicted in Figs. 4.6 through 4.9. The importance of utilizing the waste heat to its fuliest

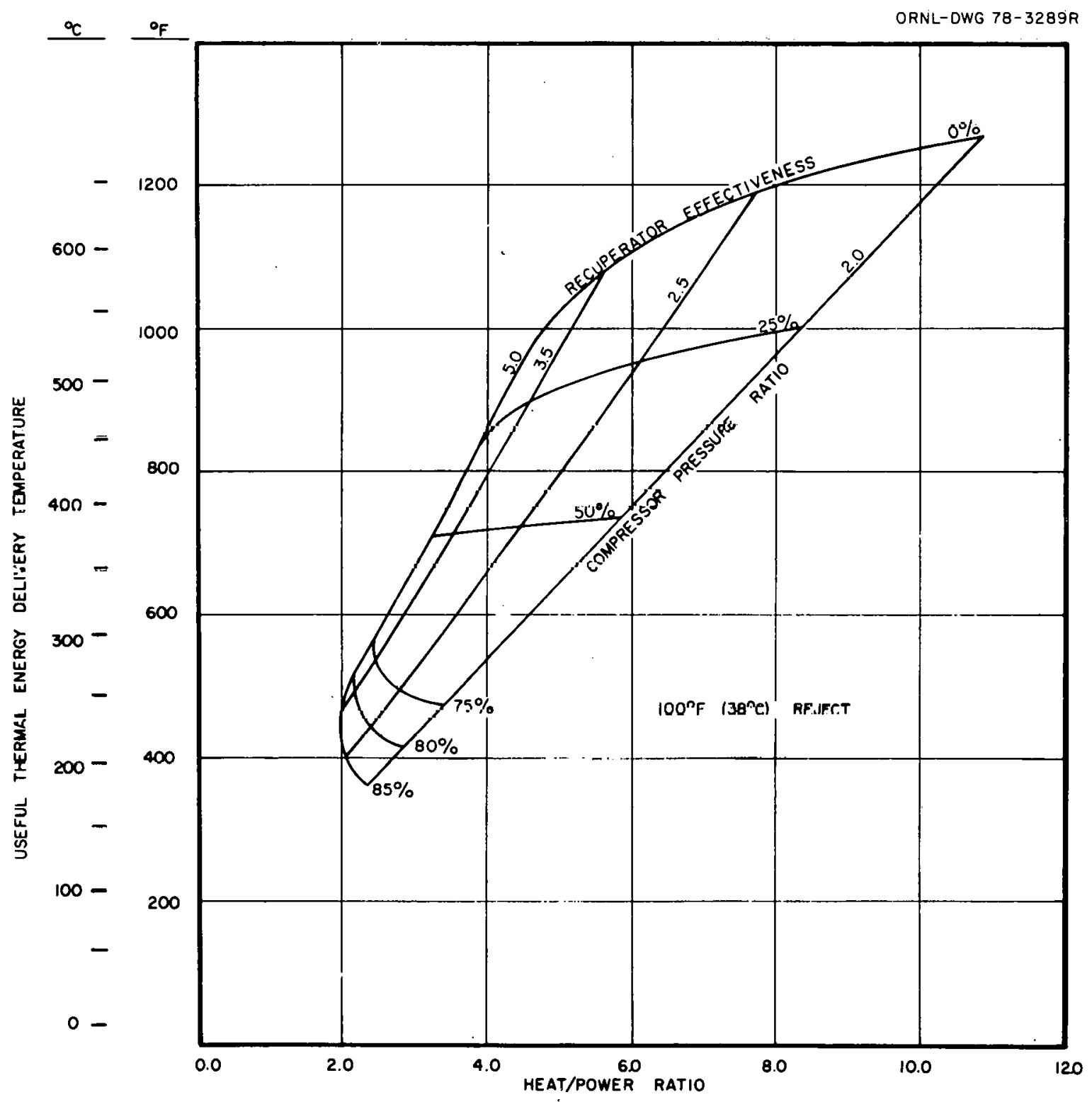

Fig. 4.6. Cogeneration capability at $100^{\circ} \mathrm{F}$ rejection. 


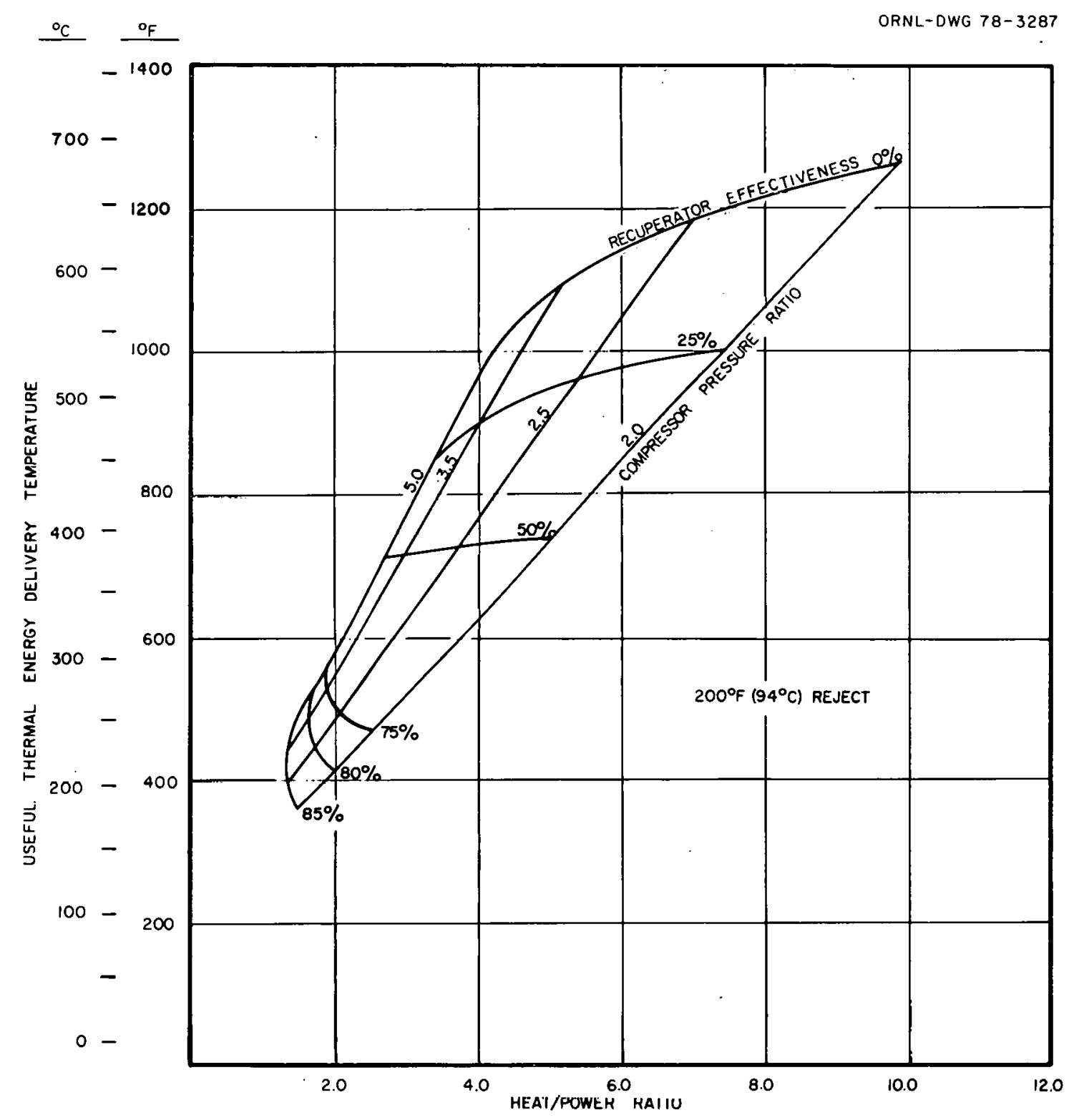

Fig. 4.7. Cogeneration capability at $200^{\circ} \mathrm{F}$ rejection.

extent is magnified at the higher electricity output if high fuel utilization is desired.

At least three scenarios may be followed in sizing a cogeneration system for a particular industrial plant or process.

1. Produce all the necessary process heat and electricity.

2. Produce the needed amount of process heat and whatever electricity rcsulto, regardless of the electricity requirements. 


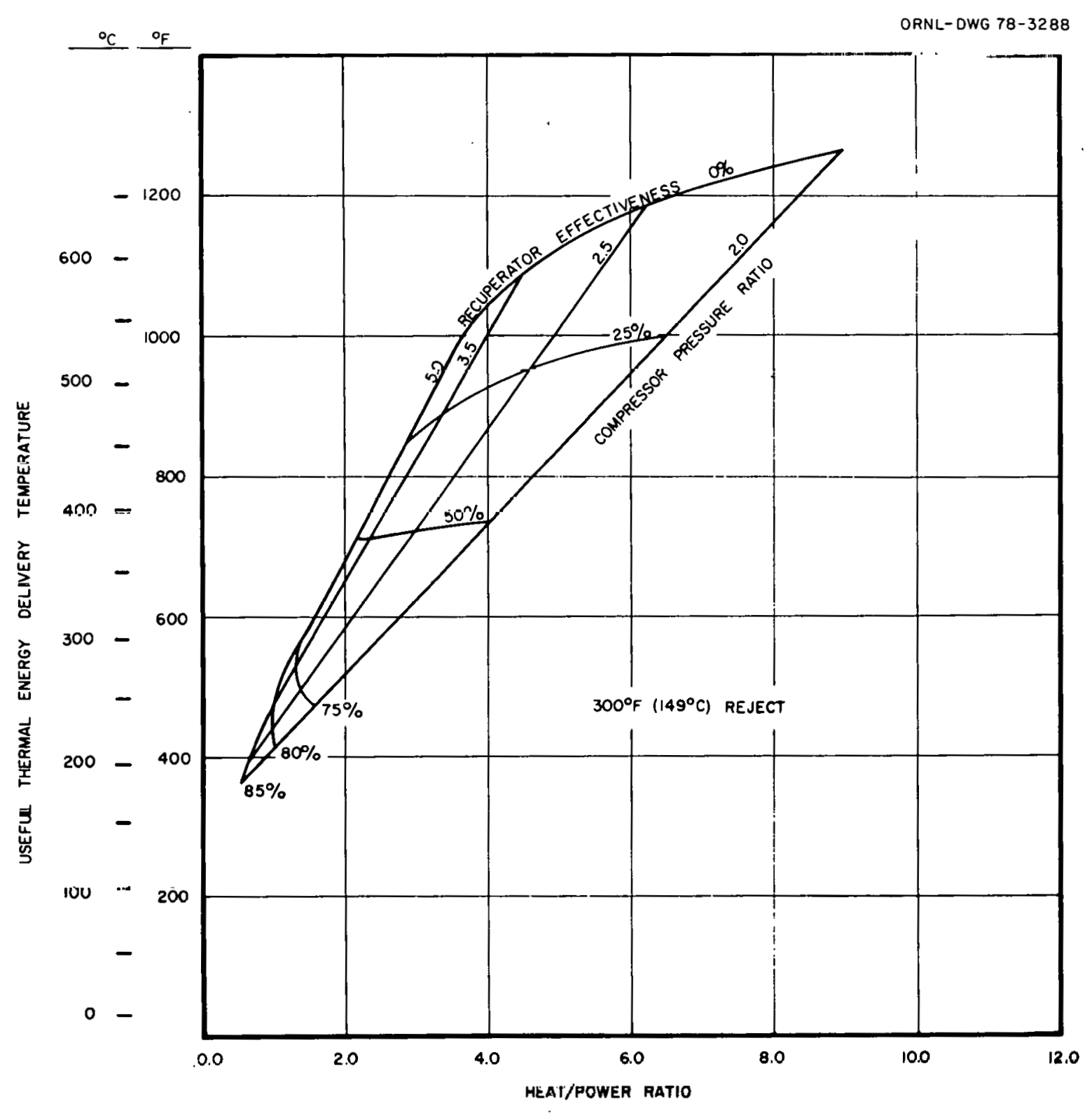

Fig. 4.8. Cogeneration capability at $300^{\circ} \mathrm{F}$ rejection.

3. Produce the needed electric power and whatever process heat follows, regardless of the process heat required at the plant:

Economics would undoubtedly play a major role in selecting a particular scheme. The price of utility electricity and the availability or lack of availability for the plant to sell its excess electricity also greatly influence the economic situation. Process heat is less 
ORNL-DWG 78-3290

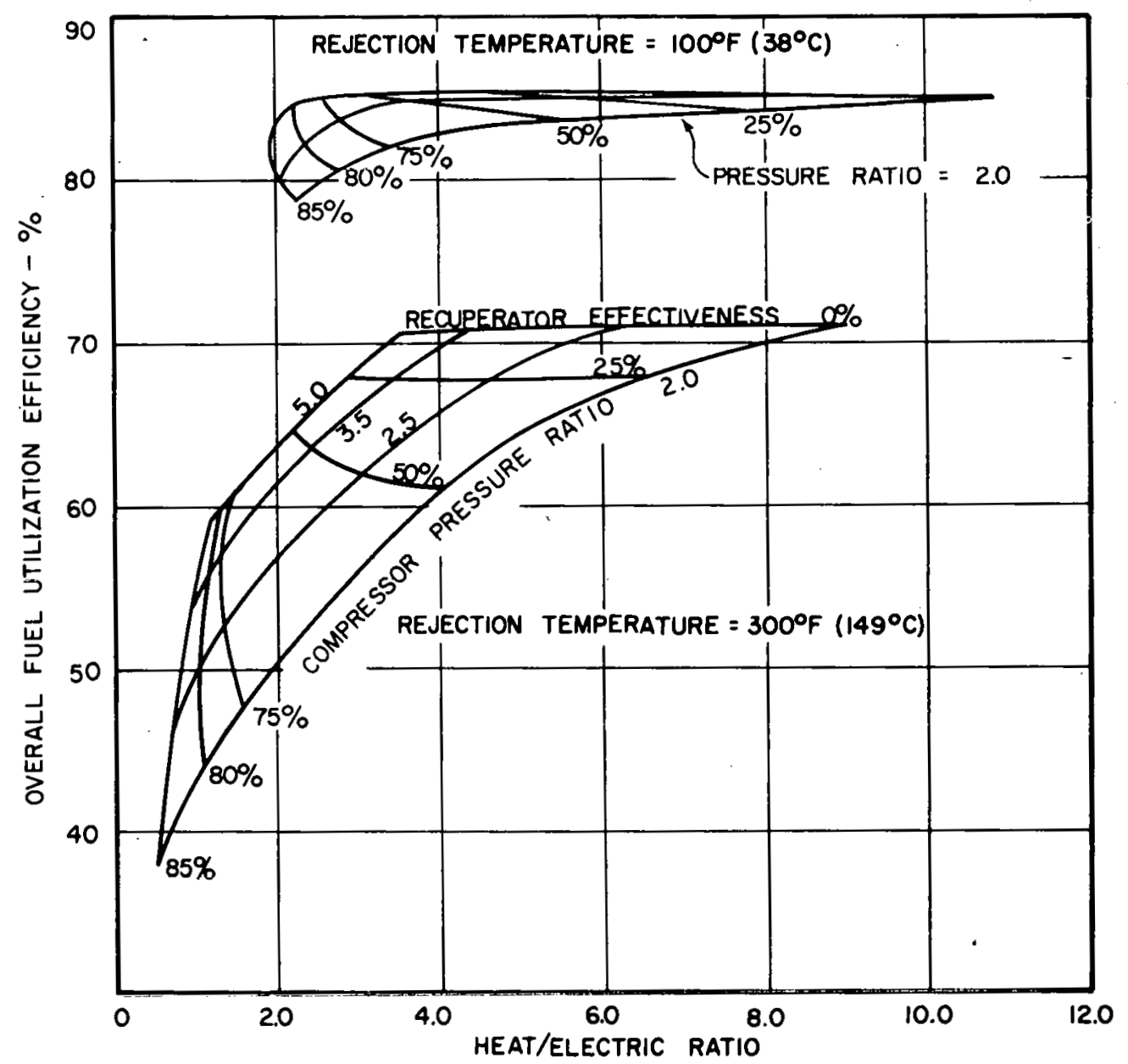

Fig. 4.9. Effect of thermal rejection temperature on overall fuel utilization.

expensive than electricity; thus, in some cases, producing additional electricity (at the expense of making the unit thermally over-sized and over-producing process heat) may be economically advantageous. In general, scenario 1 is followed in this preliminary study.

\subsection{Temperature Requirements for Industrial Process Heat}

In view of the power plant characteristics presented in the previous section, the following information is essential in selecting the proper cogeneration system, specifically, the major design parameters 
of the gas-turbine system: (1) heat/electric ratio, (2) process heat temperatures, and (3) steam and direct heat required.

Because one of the objectives of this study is to ascertain the potential oil and gas savings due to implementation of the CCC, the amount of process heat required at temperatures which can be generated by the CCC must be estimated.

The CCC can produce useful thermal energy at up to $2688^{\circ} \mathrm{C}\left(1270^{\circ} \mathrm{F}\right)$ and still generate some power. Of course, the furnace is capable of producing hot air at up to $816^{\circ} \mathrm{C}\left(1500^{\circ} \mathrm{F}\right)$. Conversely, if the procesc heat required is less than $\sim 177^{\circ} \mathrm{C}\left(350^{\circ} \mathrm{F}\right)$, it is possible that other means of heating may be more economical unless there is sufficient electrical demand. Because the applicability of the CCC appears to be best when the heat required is at temperatures of 177 to $593^{\circ} \mathrm{C}$ ( 350 to $1100^{\circ} \mathrm{F}$ ), studying industrial process heat usage broken down into temperature bands will be useful.

Comprehensive data on process heat temperatures in industry have been collated in two recent solar energy studies. Intertechnology Corporation ${ }^{5}$ collected data for industries in 78 different SIC groups but did not necessarily identify all of the process heat energy consumed in all of the groups studied. The study, however, presents data for perhaps the broadest range of industrial representatives. A listing of their process heat temperature data is presented in the Appendix. Battelle Laboratories ${ }^{6}$ performed a similar study covering 22 industries representing at least 11 two-digit SIC groups. The most comprehensive table of data from the Battelle study is also included in the Appendix. Unfortunately, the formats for presentation of the data are not identical, but comparison is presented where possible.

Process heat consumption associated with the described temperature bands ls presented in Table 4.1. A beller cumparlsun belween dala bels is obtained in regard to the six major industrial consumers. The process heat temperature spectrum on this basis is shown in Table 4.2. These data indicate that the CCC ie capable of cupplying 61 to $64 \%$ of all industrial process heat requirements. Referring to the data in Table 3.10 , converting $61 \%$ of the industrial process heating to coalfired systems would displace $21.60 \mathrm{~m}^{3} / \mathrm{sec}(870,000 \mathrm{bbl} / \mathrm{day})$ of oil and 
Table 4.1. Temperature distribution of identified process heat consumption ${ }^{a}$

\begin{tabular}{lcc}
\hline \multirow{2}{*}{$\begin{array}{c}\text { Temperature } \\
{\left[{ }^{\circ} \mathrm{C}\left({ }^{\circ} \mathrm{F}\right)\right]}\end{array}$} & \multicolumn{2}{c}{$\begin{array}{c}\text { Process heat, } \\
\text { percent of total }\end{array}$} \\
\cline { 2 - 3 } & Ref. 5 & Ref. 6 \\
\hline $177(<350)$ & 25 & 20 \\
$177-593(350-1100)$ & 28 & $\mathrm{NA}$ \\
$593-817(1100-1500)$ & 8 & $\mathrm{NA}$ \\
$817(>1500)$ & 39 & $\mathrm{NA}$ \\
\hline \multicolumn{3}{c}{$a_{\text {"Captive energy" }}$ from raw materi- } \\
als and self-generated fuels has been \\
subtracted where necessary. \\
$b_{\mathrm{NA}}=$ not available.
\end{tabular}

Table 4.2. Temperature distribution of identified process heat consuuption in six major industries combined

\begin{tabular}{|c|c|c|}
\hline \multirow{2}{*}{$\begin{array}{l}\text { Temperature } \\
{\left[{ }^{\circ} \mathrm{C}\left({ }^{\circ} \mathrm{F}\right)\right]}\end{array}$} & \multicolumn{2}{|c|}{$\begin{array}{l}\text { Process heat, } \\
\text { percent of total }\end{array}$} \\
\hline & Ref. 5 & Ref. 6 \\
\hline $\begin{array}{l}177(<350) \\
17 \%-593(350-1100) \\
593-817(1100-1500) \\
817(>1500)\end{array}$ & $\begin{array}{c}27^{a} \\
29^{b} \\
8 \\
36\end{array}$ & $\begin{array}{c}11_{b}^{a} \\
46^{b} \\
4 \\
39\end{array}$ \\
\hline \multicolumn{3}{|c|}{$\begin{array}{l}a_{\text {Reference }} 5 \text { identified substan- } \\
\text { ly more low-temperature process heat } \\
\text { rimary metals and petroleum refining } \\
\text { Ref. } 6 \text {. } \\
b_{\text {Reference } 6 \text { identified more process }}\end{array}$} \\
\hline
\end{tabular}


$4590 \mathrm{~m}^{3} / \mathrm{sec}\left(14 \times 10^{9} \mathrm{ft}^{3} /\right.$ day) of natural gas (Bureau of Mines data). The total potential savings of oil and gas thermodynamically feasible with the CCC are summarized in Table 4.3. The savings would be higher if exhaust gas supplemental firing were incorporated in the system. The CCC thermal energy in this capacity would act as a combustion air preheater for a high-temperature gas or oil flame. The $61 \%$ estimate is based on the assumption of uniform distribution of oil and gas comsumption for process heat over the process heat temperature spectrum. However, a substantial fraction of the high-temperature heat is used in the steel industry and is generated from coal. The $61 \%$ and, therefore, the savings estimate are conservative.

Table 4.3. Thermodynamically feasible savings of oil and gas with $\operatorname{ccc}^{a}$

\begin{tabular}{|c|c|c|c|}
\hline & \multicolumn{2}{|c|}{ Source of savings } & \multirow{2}{*}{ Total } \\
\hline & $\begin{array}{l}\text { Process heat } \\
\text { conversion to coal }\end{array}$ & $\begin{array}{l}\text { Electrical generation } \\
\text { by coal cogeneration }\end{array}$ & \\
\hline $0 i 1, \mathrm{~m}^{3} / \mathrm{sec}(\mathrm{bb} 1 / \mathrm{day})$ & $1.60(870,000)$ & $1.17(635,000)$ & $2.77(1,505,000)$ \\
\hline Natural gas, $\mathrm{m}^{3} / \mathrm{sec}\left(10^{9} \mathrm{ft}^{3} /\right.$ day $)$ & $4590(14 n)$ & $1328(3.75)$ & $5018(17.75)$ \\
\hline
\end{tabular}

Savings of the magnitude presented in Table 4.3 warrant further detailed assessment of the CCC and continued technological development of the system.

\subsection{Process Heat/Temperature and Power Consumption In che Six Major Industries}

Data for the six major industries are presented to assist in identifying specific manufacturers or processes that are suited to the application of the CCC cogeneration system. General characteristics of the industries needed in ascertaining practical barriers to the CCC implementation are discussed. Limited discussion is included on industrial 
process changes that would enhance the applicability of the CCC. Comparative data for the six major industries are presented here, with individual attention following in subsequent sections.

Comprehensive data for the process heat temperature, heat consumption, and electricity consumption are presented in Table 4.4. The data are predominantly from the two previously mentioned solar energy studies ${ }^{5,6}$ and reflect only the process heat and electricity consumption that has been identified with reasonable certainty. Speculative or forecast data for total consumption are not presented. An effort was made to present the data from the most extensive aggregate study of industrial subgroups. The capabilities of the CCC system indicate applications in all industries listed, with the possible exception of the iron and steel manufacturers. The petroleum refining industry shows a large value of process heat in the temperature band most suited to the CCC. A more detailed discussion of the industries follows.

\subsubsection{Primary metals}

This evaluation subdivides primary metal production into three subsectors: (1) iron and stee1, (2) aluminum, and (3) copper. From the work of Reding and Shepherd, ${ }^{8}$ the fuels used by these three groups in 1972 are listed in Table 4.5. Recall from Table 3.9 that $289 \%$ of the oil and gas purchased as fuel is consumed in various process heaters or steam generators.

4.3.1.1 Iron/steel. If the coke energy for blast furnaces is included, the iron and steel manufacturers are the greatest consumers of energy in the industrial sector. In 1973, the steel plants in the United States consumed $24009 \times 10^{12} \mathrm{~kJ}\left(3800 \times 10^{12} \mathrm{Btu}\right)$ of energy (electric $3413 \mathrm{Btu} / \mathrm{kWh} \mathrm{r})$. Production was carried out in 43 integrated iron and steel plants and 118 electric furnace steel plants, with a total production of about 150 million tons. ${ }^{6}$ A flow diagram for steel-making industries is provided in Fig. 4.10 (Ret. 6).

Table 4.6 summarizes process heat requirements for 12 processes in iron and steel production. In the blast furnace, a portion of the coke input serves to reduce the iron oxide to iron and does not actually provide process heat. An estimate of the energy required to melt iron 
Table 4.4. Annual process heat/tenperature and electric requiremens for six major industries

\begin{tabular}{|c|c|c|c|c|c|c|c|c|c|c|}
\hline \multirow{2}{*}{ Industry } & \multicolumn{8}{|c|}{$\begin{array}{l}\text { Process heat consumption } \\
\left.\left[1 \mathrm{C}^{12} \mathrm{~kJ} \cdot 10^{12} \mathrm{Btu}\right)\right]\end{array}$} & \multirow{2}{*}{$\begin{array}{l}\text { Electricity } \\
\left(10^{9} \mathrm{kWn} r\right)\end{array}$} & \multirow{2}{*}{$\begin{array}{c}\text { Date } \\
\text { (reference) }\end{array}$} \\
\hline & $<177^{\circ} \mathrm{C}$ & $\left.\therefore<350^{\circ} \mathrm{F}\right)$ & $17-593^{\circ} \mathrm{C}$ & $\left(350-1100^{\circ} \mathrm{F}\right)$ & $593-816^{\circ} \mathrm{C}$ & $\left(1100-1500^{\circ} \mathrm{F}\right)$ & $>816^{\circ} \mathrm{C}$ & $\left(>1500^{\circ} \mathrm{F}\right)$ & & \\
\hline Iron/steel & 69 & i65) & 0 & (a) & & $0(0)$ & 1806 & $(1712)$ & $57.5^{a}$ & $1973(6)$ \\
\hline Petroleum & 63 & $i 60)$ & 2958 & $(2804)$ & 241 & 1 (230) & & $(0)$ & $23.1^{\vec{D}}$ & $19.73(6)$ \\
\hline Chemicals & - $\quad 3 \approx 2$ & i\$05) & 195 & $(: 85)$ & & $0(0)$ & 37 & (35) & $80.0^{c}$ & $1977(5)^{d}$ \\
\hline Stone/clay/glass & 77 & (73) & 19 & (18) & & $2(11)$ & 1080 & $(1024)$ & $24.0^{e}$ & $1974(6)$ \\
\hline Food processing & $2 ; 1$ & 1256) & 64 & $(6 \cdot 1)$ & & $0(0)$ & & $(0)$ & $36.0^{e}$ & 1977 (5) \\
\hline
\end{tabular}

$a_{20 \%}$ generated in- -1 lar.t.

$b_{\text {Electricity value frcm Ref. } 7 .}$

Electricity value frcm Ref. 8; additional generated in $\rightarrow$ plant.

$d_{\text {Reference }} 8$ shows abcut $1250 \times 10^{12}$ total frocess heat consumption.

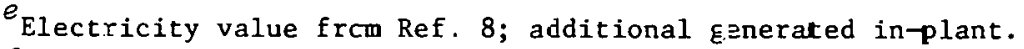

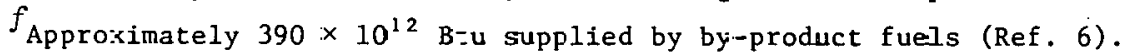


Table 4.5. Energy consumption and distributions in the primary metals industries in 1972

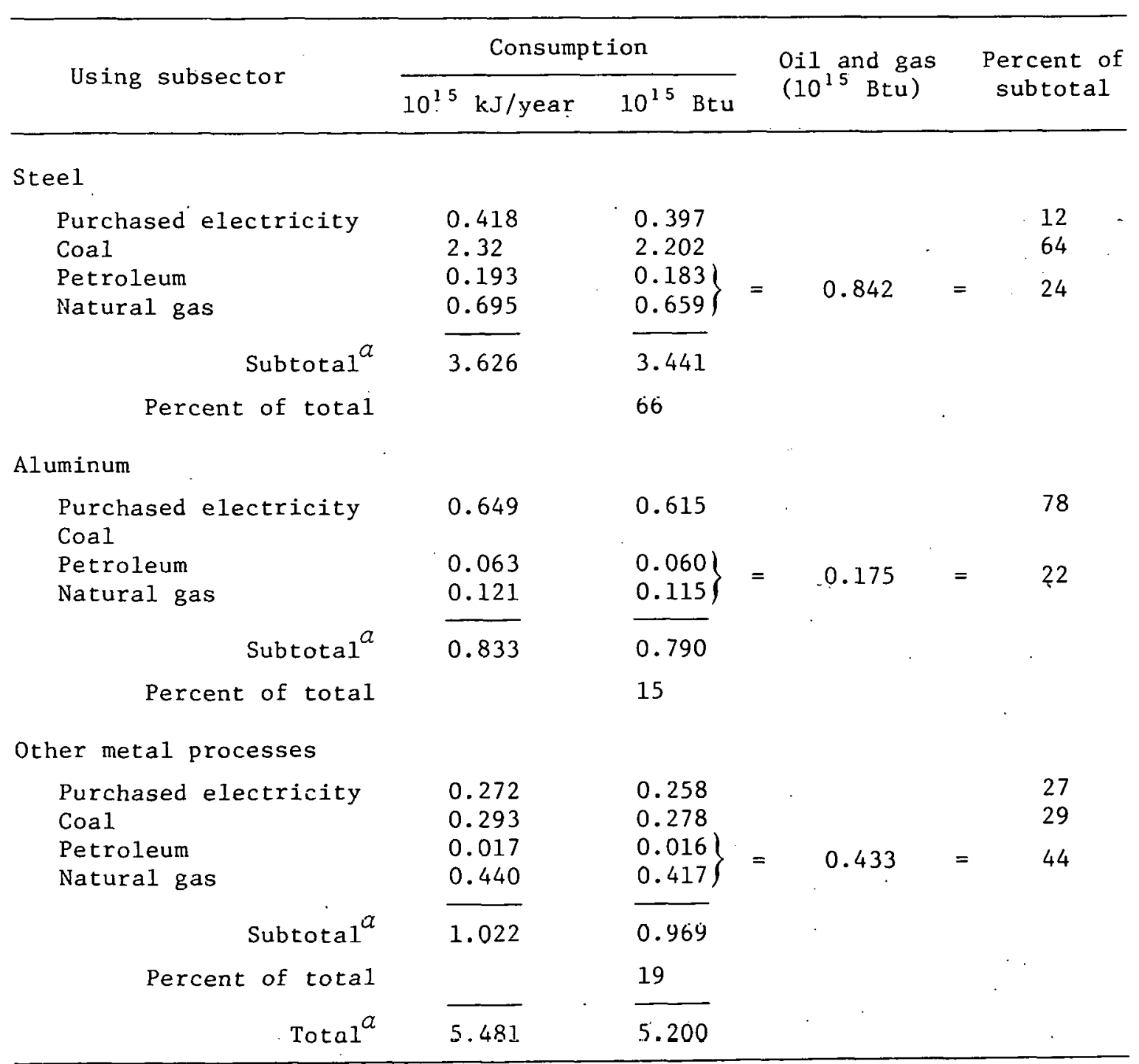

${ }^{a}$ Accuracy of energy consumption figures estimated to be within $\pm 10 \%$ (Ref. 8).

was obtained from data for electric furnace steel production in which the charge (steel scrap) is already reduced. This estimate is shown as the process heat consumption in the blast furnace. ${ }^{6}$ By-product fuels (coke oven gas and blast furnace gas) contribute about $777 \times 10^{12} \mathrm{~kJ}$ $\left(740 \times 10^{12} \mathrm{Btu}\right)$, which is $42 \%$ of the identified process heat. Most of the process heat is required at temperatures well above the capabilities 


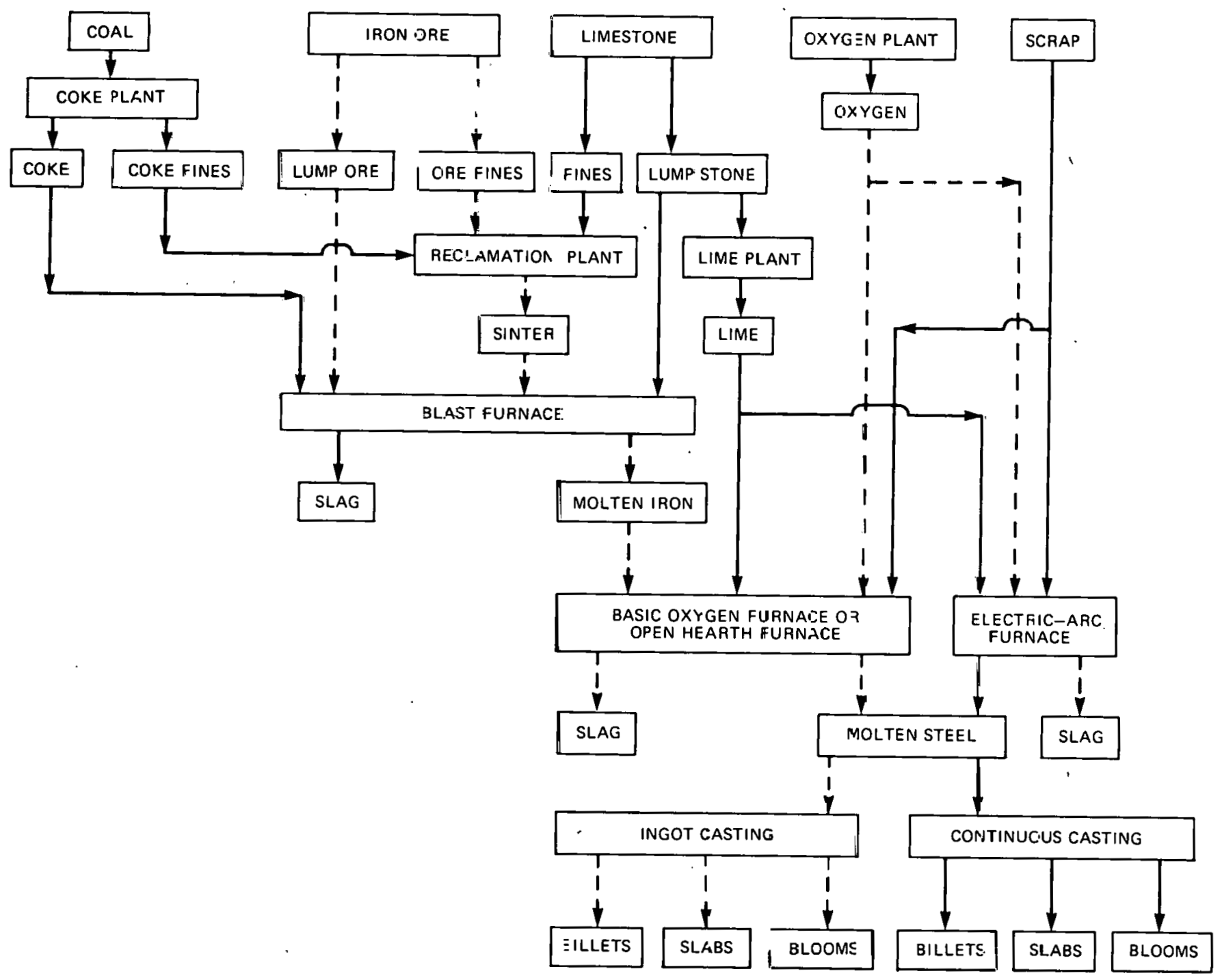

Fiz. 4.10. Generalized flow diagram of the steel-making industry. 
Table 4.6. Process heat requirements in the iron and steel industry, 1973

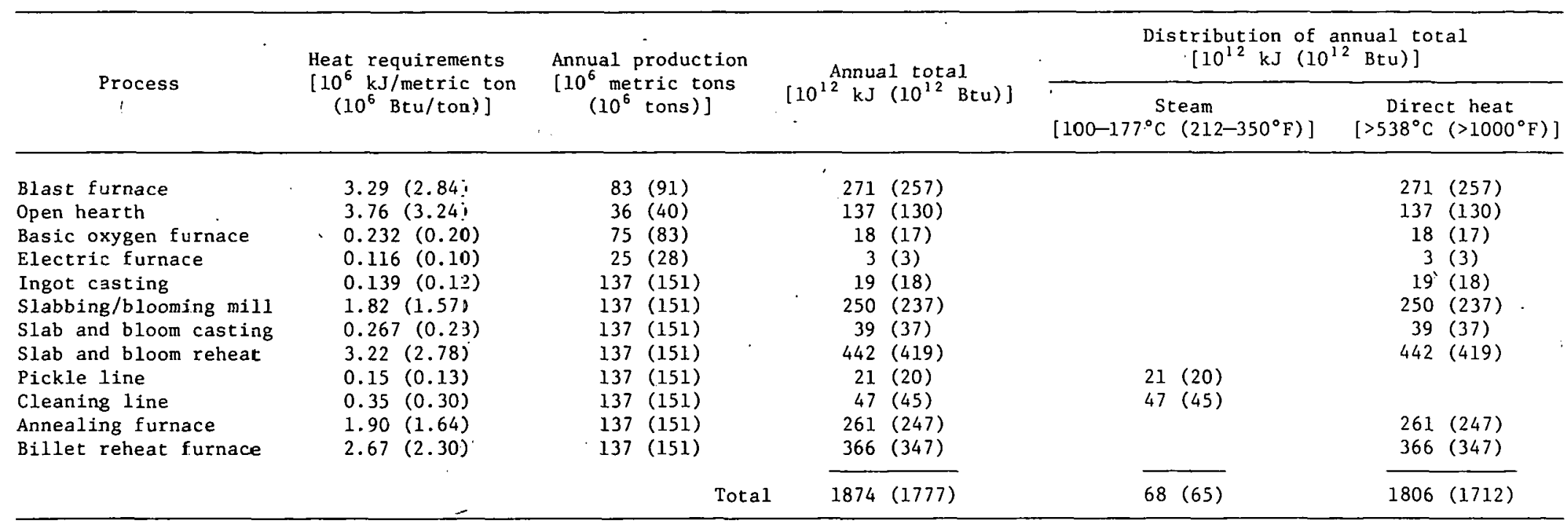


of a fluidized bed. However, the electric demand of the steel industry has apparently made in-house generation attractive (refer to Table 4.4); thus the CCC may be economically desirable, even though operating at a rather low overall fuel efficiency. Although displacement of the oiland gas-fired process heaters by fluidized beds does not appear thermodynamically feasible, some possibilities eventually may exist because of the nature of the industry. Some reasons for this conclusion are listed below.

1. Approximately $80 \%$ of the total production of raw steel takcs place in Illinois, Indiana, Ohio, Pennsylvania, and in plants in or near Detroit, Mich1gan, Baltimore, Maryland, and Buffalo, New York. This region, in varying degrees, experiences shortages and curtailuents of natural gas and has excellent access to very large supplies of highsulfur noncompliance coal. well suited for use in fluidized-bed combustors. Coal converted to coke is'a necessity in integrated* steel plants. The larger steel producers own captive mines and are well equipped to store and handle coal.

2. The U.S. steelmakers are currently suffering from intense competition from the newer and more effirient postwar ctool milln in Japan and Federal Republic of Germany; for example, Battelle ${ }^{9}$ reports these 1.973 consumption rates:

$\begin{array}{ccl}10^{6} \mathrm{~kJ} \text { per metric ton } & \begin{array}{l}\text { Relative energy } \\ \left(10^{6} \mathrm{Btu} \text { per ton }\right) \\ \text { consumption per }\end{array} \\ \text { Country } & \text { of steel shipped } & \text { ton of raw steel }\end{array}$

United states United Kingdom Federal Republic of Germany Japan

$\begin{array}{llr}39.2(33.8) & 100 \\ 40.3(34.7) & 101 \\ 34.1(29.4) & 87 \\ 30.5(26.3) & 76\end{array}$

3. The assumption is made that, in the future and referenced to the sum of heat and power, fluidized-bed energy systems used in steel production will show superior overall efficiency and lower net costs.

"Integrated" plants, as opposed to "cold-metal" plants, conduct all phases of steel-making, starting with iron ore and ending with finished products. Cold-metal plants begin processing with scrap and pig iron. 
If this is the case, there exists incentive to spend the capital for their adoption.

4. To operate efficiently, steel mills must operate continuously and at or near full capacity. Reliable in-house energy production with coal to achieve freedom from shutdowns caused by curtailments of natural gas and utility-produced electricity is a powerful incentive.

5. Related to item 4, the possibility that regulated electrical rates will not only rise but will no longer include discounts for large industrial users cannot be ignored. This becomes an additional incentive to achieve a lower-cost independent and unregulated supply of in-houseproduced electricity using readily available noncompliance coal.

Further evidence indicating possible implementation of the CCC system in steel-making can be presented. There are wide variations in the energy forms and distributions required by different processing facilities with differing product lines. Figure 4.11 shows fractional distributions of energy sources for both integrated and cold-metal companies. The cold-metal companies not requiring coal as a reductant are heavily dependent on gas and petroleum, use little coal, and consume relatively large amounts of electricity. Cold-metal processing accounts for 10 to $15 \%$ of the total production.

Assessments that estimate the near-term usage of coal-fired gasturbine energy systems in this industry do not envision replacement of the coal used for coke to reduce oxide ores. Directly or indirectly, on some time scale, energy produced in CCC systems is theoretically capable of replacing all but a very small fraction of the natural gas and petroleum used over a wide range of temperatures to process metallic steel and iron. The forming of finished steel products, sheets, bars, wire structural shapes, and pipe and tubing consumes large volumes of natural gas in soaking pits and reheating furnaces that produce the softening temperatures $\left[1204\right.$ to $1315^{\circ} \mathrm{C}$ (2200 to $\left.2400^{\circ} \mathrm{F}\right)$ ] which enable plastic forming by rolling, drawing, forging, and similar procedures. These temperatures exceed by a wide margin the peak temperature of the direct heat available in the gas-turbine loop; however, they are readily attainable with turbine-produced electricity. Electrical energy is capable of producing the temperatures required to melt, form, and heat 


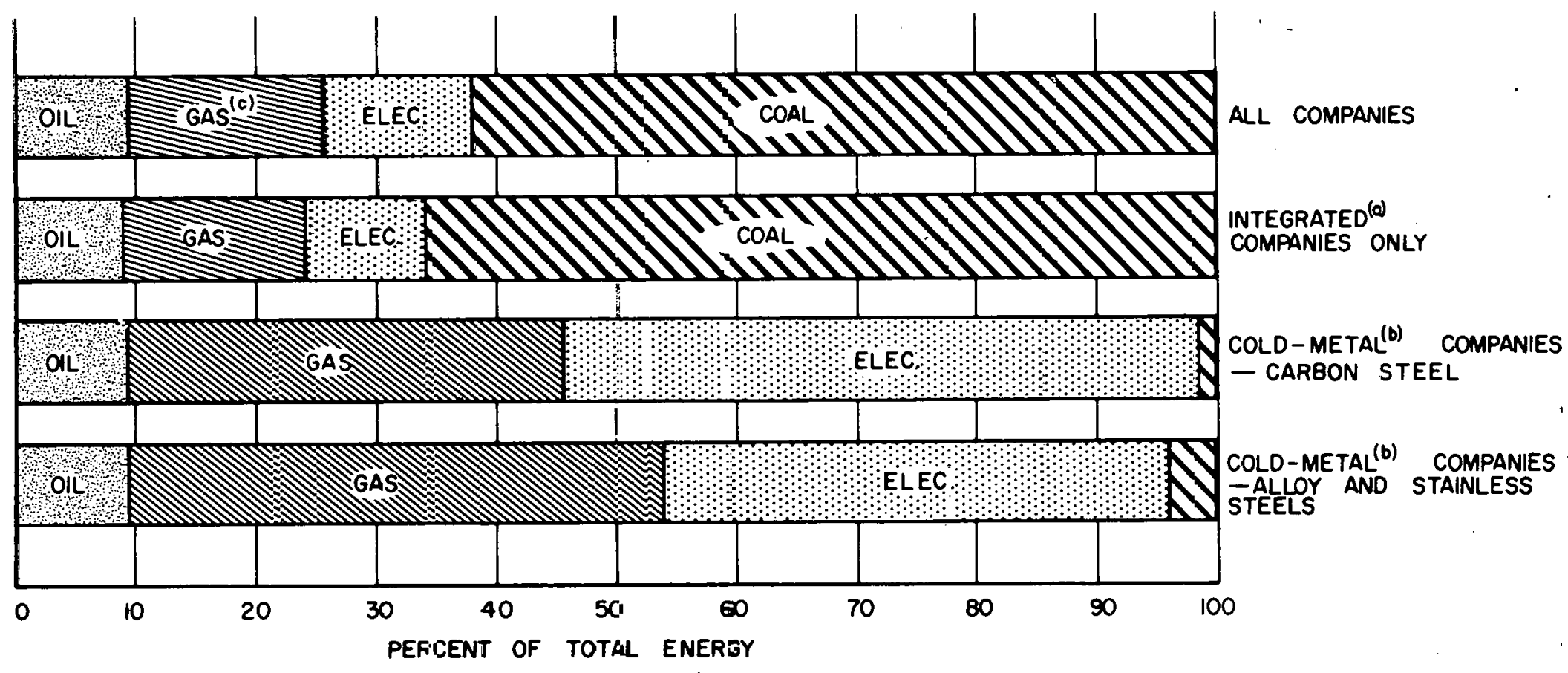

(a) "Integrated" companies are engaged in all phises of steel production, from ore to finished product.

(b) "Cold-meta:" companies do not have frocessing facilities (blest furnàces) for reducing ore to metallic iron.

(c) The steel industry uses $26 \%$ of the tctal natural gas required by industry.

Fig. 4.11. Distribution of energy sources in the steel industry in 1975 (from American Iron and Steel Institute statistics). 
treat steel and other metals. Electric melting of scrap and pig iron in steel mills and foundries has been steadily replacing fossil-fired open hearth furnaces. This trend began before fuel shortages became acute. Induction, resistance, and radiant heating with electricity has been reduced to well established practice. With ample and economical electrical power, the iron and steel industry is technologically capable of becoming virtually independent of continuing supplies of fuel oil and natural gas.* Lower-temperature energy for direct heat and steam as required in a particular facility is easily extracted from a CCC loop.

On a long-term basis, if blast furnaces are replaced by alternative direct reduction processes that use gaseous reducing agents (carbon monoxide and/or hydrogen), the opportunity to employ gas turbines that produce heat and electricity will expand. A large variety of alternative direct ore-reduction processes are described briefly in Ref. 10. Table 4.7 lists eight of these with typical maximum temperatures required within the process. The list is not complete.

A review of these and similar ore-processing methods leads to the following observations.

1. The iron and steel makers worldwide are actively pursuing developments intended to supplant and replace the blast furnace for ore reduction.

2. Some of these processes are in successful operation, notably in Scandinavia, where gas has been scarce and electricity relatively plentiful.

3. Processes based primarily on using hydrogen as a reducing agent are becoming practicable.

4. The temperatures, compared with blast furnaces, are low - in some cases $<816^{\circ} \mathrm{C}\left(1500^{\circ} \mathrm{F}\right)$.

5. Melting, subsequent to ore reduction, is readily accomplished in electric furnaces.

The assumption is not unreasonable that, with hydrogen and after thorough and intensive engineering development, coal and coke used as

\footnotetext{
* Relatively small amounts of hydrocarbon gases will be required to ubliin furnace atmospheres in a variety of processes.
} 
Táble 4.7. Tenperatures and reducing agents in repzesentative cirect-reduction processes for iron production

\begin{tabular}{|c|c|c|c|c|}
\hline & $\begin{array}{l}\text { Process } \\
\text { identification }\end{array}$ & $\begin{array}{l}\text { Eəducing } \\
\text { agents }\end{array}$ & Process =emperazures & Remarks \\
\hline 1. & $\mathrm{Nu}-\mathbf{i}$ ron & $\begin{array}{l}\mathrm{H}_{2}, \sim \mathrm{Bj} \% \\
\mathrm{CO}, 15 \%\end{array}$ & $\begin{array}{l}\text { Maximum gas }-843^{\circ} \mathrm{C}\left(155 \mathrm{C}^{\circ} \mathrm{F}\right) \\
\text { Freheated ore }-920^{\circ} \mathrm{C}\left(17130^{\circ} \mathrm{F}\right)\end{array}$ & $\begin{array}{l}\text { Deveioped by U.S. Steel; a plant with a capacity of } \\
1 \text { milion tons per year of } 75 \% \text { recuced briquetces } \\
\text { under constriction in Venezuela }\end{array}$ \\
\hline 2 . & H-iron & $\mathrm{H}_{\bar{z}}, \quad 285 \%$ & $\begin{array}{l}\text { 3eduction }-538^{\circ} \mathrm{C}: 1000^{\circ} \mathrm{FI} \\
\text { Froduct deactivation }-87 \mathrm{~L}^{\circ} \mathrm{C}\left(1600^{\circ} \mathrm{F}\right)\end{array}$ & A lcw-temperatare, high-pressure $(\backsim 400-p s i)$ process \\
\hline 3. & $\begin{array}{l}\text { Arthur D. Little } \\
\text { (Esso research - } \\
\text { Little process) }\end{array}$ & $\begin{array}{l}\mathrm{H}_{z},{ }_{2} 41 \% \\
\mathrm{CO}, 2.21 \% \\
\mathrm{~N}_{z},{ }_{2}=3.3 \%\end{array}$ & $\equiv 16-871^{\circ} \mathrm{C} \quad\left(1500-1600^{\circ} \mathrm{F}\right)$ & See item 4 \\
\hline 4. & FIOR & $\begin{array}{l}\mathrm{H}_{\tilde{2}}, 241 \% \\
\mathrm{Co}, 221 \% \\
\mathrm{~N}_{2}, 233 \%\end{array}$ & & $\begin{array}{l}\text { A further development of the Arthur D. Little pro- } \\
\text { cess; a 300-tod/day plant has been operating in } \\
\text { Nova Scotia since } 1965\end{array}$ \\
\hline 5 . & Stelling & $\mathrm{CO}$ & $593-704^{\circ} \mathrm{C}\left(1100-13130^{\circ} \mathrm{F}\right)$ & $\begin{array}{l}\text { Develope } 1 \text { in Sweden; CO is the principal reducing } \\
\text { agent; hydrçen (al impurity), if used, prevents } \\
\text { fluidized-bed operation }\end{array}$ \\
\hline 6 . & Norwegian $\mathrm{H}$-iran & $\mathrm{H}_{\mathbf{z}}$ & $\equiv 99^{\circ} \mathrm{C}\left(1650^{\circ} \mathrm{F}\right)$ & $\begin{array}{l}\text { Reduction to iron takes place in an electric fur- } \\
\text { nace at } 899^{\circ} \mathrm{O}\left(165 \mathrm{~J}^{\circ} \mathrm{F}\right)\end{array}$ \\
\hline 7. & Wiberg-Saderfors & $\begin{array}{l}\mathrm{H}_{\dot{a}}, \quad 20-30 \% \\
\mathrm{CO}, 70-80 \%\end{array}$ & 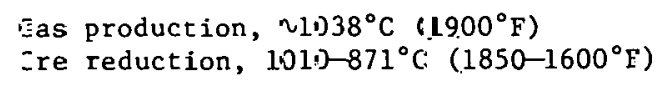 & $\begin{array}{l}\text { Several plants operating in Sweden; the largest, } \\
\text { built in 1952, has a capacity of } 20,000 \text { tons/year }\end{array}$ \\
\hline 8 . & Novalfer - Onia & $\begin{array}{l}\mathrm{H} \\
\mathrm{CO}\end{array}$ & $593-704^{\circ} \mathrm{C}\left(1100-1300^{\circ} \mathrm{F}\right)$ & Develofed in France to process Algerian ores \\
\hline
\end{tabular}


a reducing agent can be eliminated as a processing step in steel production. The heat and electricity required to accomplish ore reduction and refining is obtained readily from abundant and inexpensive noncompliance coal in fluidized-bed systems. The assumption is also made that the hydrogen will be produced from coal, rather than by reforming natural gas. Alternatively, combining steam reforming of the coal to make carbon monoxide and hydrogen in the same fluidized beds used to develop power and process heat may be worth consideration.

If these developments take place, the long-term potential of fluidized-bed systems to produce heat and power for steel production systems would be greatly expanded. Ail energy forms and processing temperatures required to produce steel fall within the capability of fluidized-bed combustors coupled to gas turbines. Theoretically, if energy efficiencies per ton of steel remain unchanged by such a change in production methodology and if steel production remains at the 1973 level, then the market potential of efficient and reliable fluidized-bed energy production will approach $100 \%$ of the steel industry's requirements, resulting in the following theoretical market:

U.S. shipments, 1973

Total annual energy rate

Total theoretical number of 100-MW CCC units at $100 \mathrm{MW}$ each to maintain the 1973 production level
$86.7 \times 10^{6}$ metric tons $\left(95.5 \times 10^{6}\right.$ tons $)$ $880 \times 10^{6} \mathrm{MW}\left(3.0 \times 10^{15} \mathrm{Btu} / \mathrm{hr}\right)$

10,000

This $100 \%$ forecast and the assumptions on which it rests are extravagant and not for the near time. The forecast is included only to show that, neglecting cost considerations, the steel industry is potentially capable of large-scale reductions in its consumption of gas and petroleum by more extensive use of nonmetallurgical, noncompliance coal for heat and electricity and, further, that fluidized-bed systems are a very promising approach to achieving these reductions. Consider that possibly $25 \%$ of the-previous theoretical market is realistic in the not too distant future. The opportunity to produce 2500 CCC modular systems of $100 \mathrm{MW}$ each should attract the attention of equipment huilders. 
4.3.1.2 Primary aluminum production. After steel, aluminum production consumes more energy than that required to produce any other metal. Table 4.8 shows total fuel usages. That aluminum production is electrically intensive and, further, that coal usage is negligible is immediately apparent. Aluminum processing can be broadly subdivided into two general subprocesses: (1) raw material preparation and (2) electrolytic, reduction to metallic aluminum. These processes are diagrammed in Fig. 4.12. The Hall process is almost standard throughout the industry, but Alcoa is developing an alternative (Fig. 4.13) that is reported to use $30 \% 1$ ess electricity. Although new and better processes may be successfully developed and applied, the Hall process for electrolytic reduction will probably dominate the industry for an appreciable period. Heat requirements for some of the subprocesses are given in Table 4.9. The fuel used for the calcining operations and steam generation is predominantly natural gas.

The bauxite refining plants display heat/power requirements in the range of the CCC output. These refineries are generally separate facilities from the smelting operations. Displacement of the $40.3 \times 10^{12} \mathrm{~kJ}$ $\left(38.4 \times 10^{12} \mathrm{Bcu}\right)$ of cnergy for steam generation would be equivalent to $1.05 \times 10^{9} \mathrm{~m}^{3}\left(37 \times 10^{9} \mathrm{ft}^{3}\right)$ of natural gas. Further oil and gas conscrvation, of course, would follow from the in-house coal-produced electric1ty. Bauxite is refined at nine plants in the United States that are owned by five different primary aluminum producers.

The total energy consumption by the aluminum industry has not changed appreciably in recent years. The Aluminum Association reports that energy efficiency increased $7.6 \%$ during the period 1972 through 1976. The almost constant total annual use rate is concluded to be the result of escalating production rates. Because of the great dependency on electricity, smelting plants have traditionally been located near sources of abundant and inexpensive power, particularly hydro sources. For this reason, aluminum smelters actually place little burden on the nation's rarer nonrenewable fuels; exceptions are some gas-fired power stations owned by aluminum companies in Texas, traditionally a location for inexpensive natural gas. 
Table 4.8. Energy consumption and distribution ${ }^{\alpha}$ by source in the aluminum industry in 1972 and 1976

\begin{tabular}{|c|c|c|c|c|}
\hline \multirow{3}{*}{ Source } & \multicolumn{4}{|c|}{ Consumption and distribution } \\
\hline & \multicolumn{2}{|l|}{1972} & \multicolumn{2}{|l|}{1976} \\
\hline & $10^{15} \mathrm{~kJ}\left(10^{15} \mathrm{Btu}\right)$ & $\begin{array}{l}\text { Percent of } \\
\text { total }\end{array}$ & $10^{15} \mathrm{~kJ}\left(10^{15} \mathrm{Btu}\right)$ & $\begin{array}{l}\text { Percent of } \\
\text { total }\end{array}$ \\
\hline $\begin{array}{l}\text { Natural gas and liquefied } \\
\text { petroleum gas (LPG) }\end{array}$ & $0.234(0.222)$ & 24.1 & $0.212(0.201)$ & 22.1 \\
\hline Liquid petroleum & $0.026(0.025)$ & 2.7 & $0.034(0.032)$ & 3.5 \\
\hline Petroleum zoke and pitch & $0.075(0.071)$ & 7.7 & $0.077(0.073)$ & 8.0 \\
\hline Coal & $0.008(0.008)$ & 0.9 & $0.005(0.005)$ & 0.5 \\
\hline \multicolumn{5}{|l|}{ Electricity } \\
\hline Hydro & $0.109(0.103)$ & 11.2 & $0.124(0.118)$ & 12.9 \\
\hline Purchased & $0.317(0.300)$ & 32.6 & $0.353(0.335)$ & 36.7 \\
\hline Subtotal & $0.426(0.403)$ & 43.8 & $0.477(0.453)$ & 49.6 \\
\hline In-house & $0.202(0.191)$ & 20.8 & $0.157(0.149)$ & 16.3 \\
\hline Total electricity & $0.628(0.594)$ & 64.6 & $0.634(0.602)$ & 65.9 \\
\hline Total & $0.971(0.920)$ & 100.0 & $0.964(0.913)$ & 100.0 \\
\hline
\end{tabular}

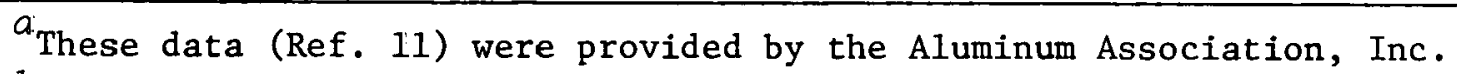

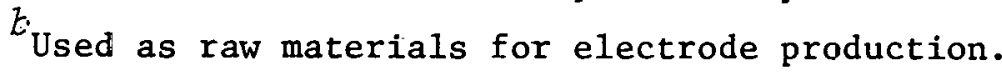




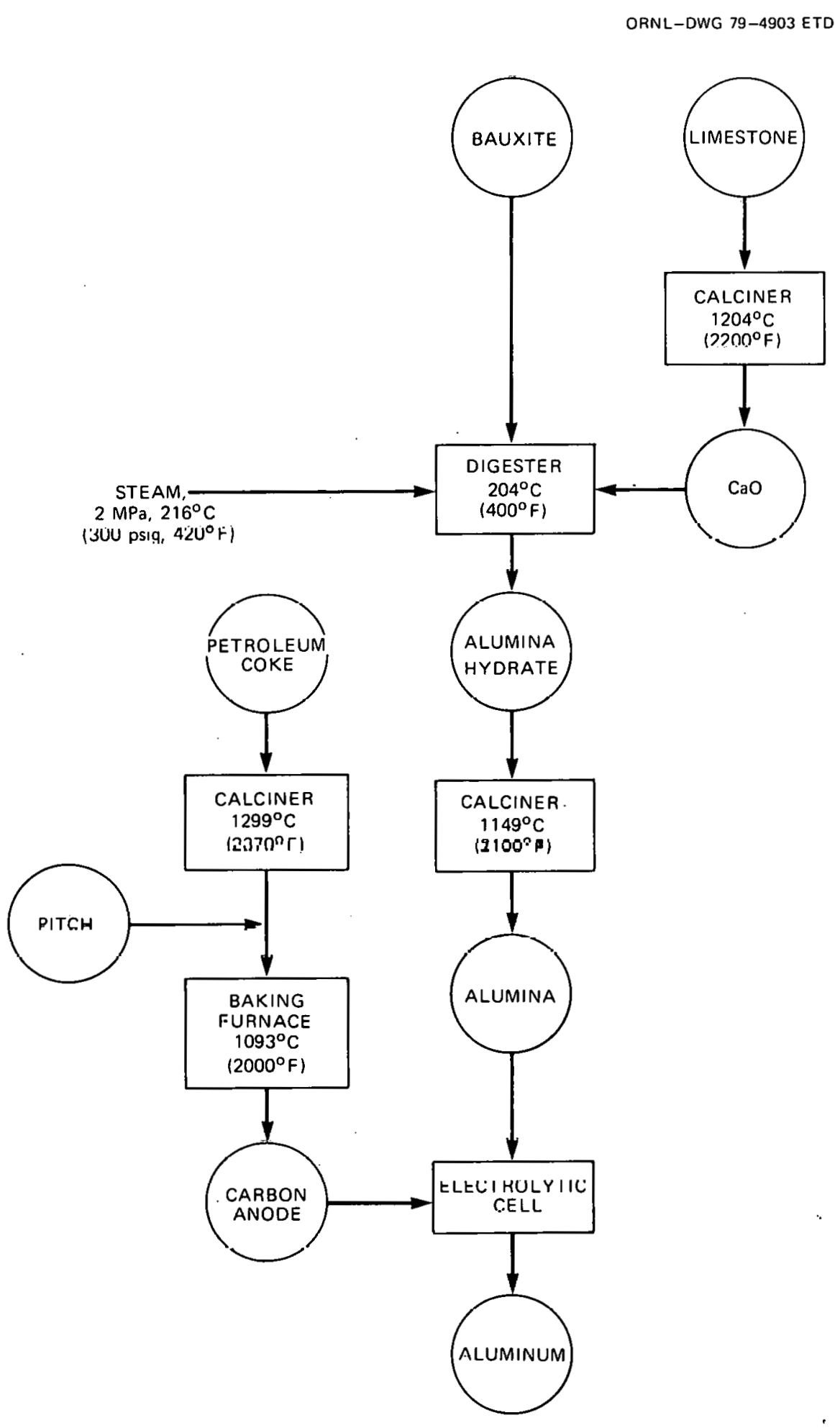

Fig. 4.12. Major processes and heat requirements for production of aluminum meta1 (Ref.6). 
Table 4.9. Process heat isteam $^{a}$ and electrical ${ }^{b}$ requirements in production of aluminum metal,

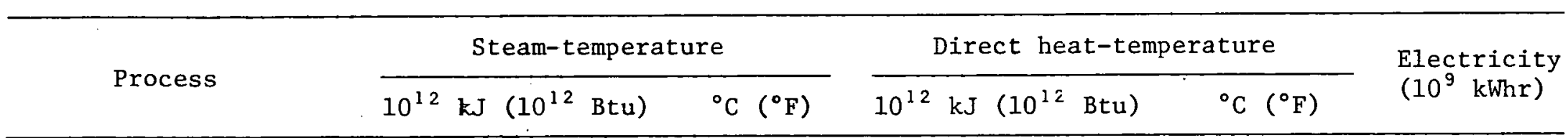

Bayer

Calcining limestone

Digestion

$40.5(38.4)$

$216(420)$

$2.03(1.92)$

1204 (2200)

$36.1(34.2)$

$1149(2100)\}$

1.7

$\stackrel{q}{2}$

Hall/Heroult

Calcining coke

Anode baking

Electrolytic =ell

$7.8(7.4) \quad 1299(2370)$

$20.7(19.6) \quad 1093(2000)$

(smelting plant)

$a_{\text {Reference } 6 \text {. }}$

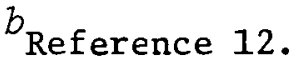




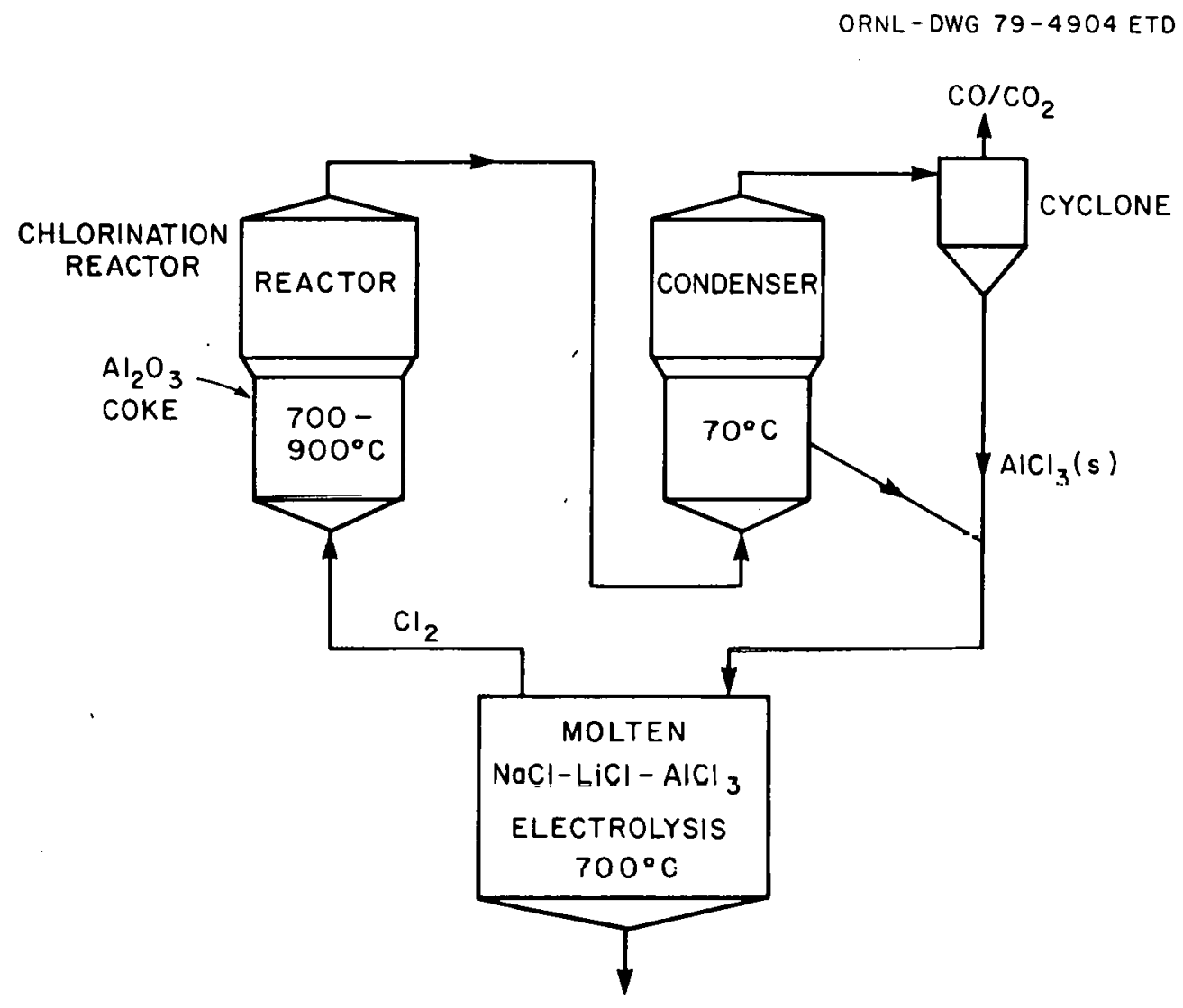

Fig. 4.13. Alcoa smelting process flow sheet.

4.3.1.3 Conper production. The production of metallic cuppes Irum sulfide ores can be divided into four steps: (1) mining, (2) beneficiation, (3) smelting, and (4) refining. Reference 13 analyzes, four sets of energy consumption data reported in Refs. 14 through 21 . Their results have been used in Table 4.10.

The copper industry is strongly dependent on electricity to mine and concentrate sulfide ores and to electrolytically refine the impure silleltcd metal. Uften, tlie Luur subprocesses required to produce pure metallic copper are now performed at widely separated locations. For example, ore mined in Butte, Montana, has been smelted in Anaconda, $43 \mathrm{~km}$ (27 miles) away, and electrolytically refined in Great Falls, Montana. Assessments of potential retrofit applications of CCC systems to existing facilities consider these geographical separations and do not assume energy distributions based on the complete process. Figure 4.14 
Table 4.10. Estimated ${ }^{a}$ energy consumption by primary copper production in 1973

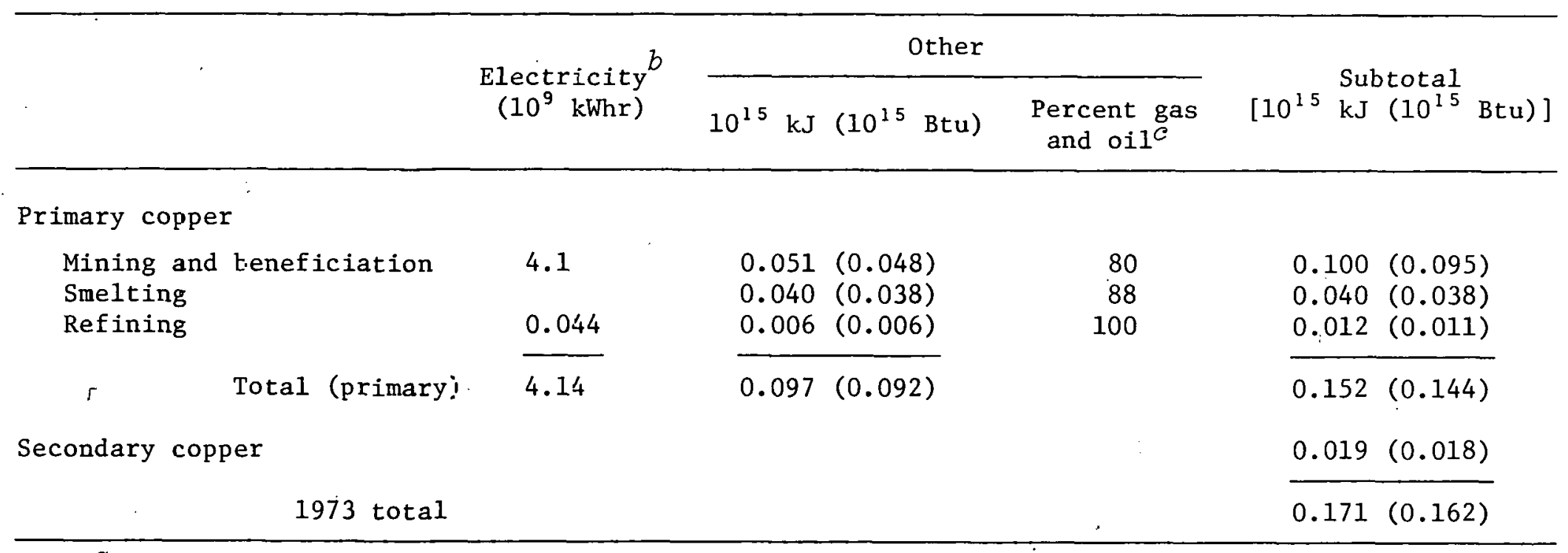

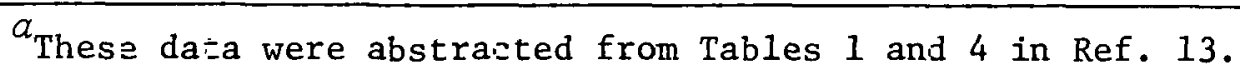

$b$ Average of values reported by Chapman and Bravard and listed in Table 4 of Ref. 13.

${ }^{e}$ Approximate values derived from Ref. 21 . 


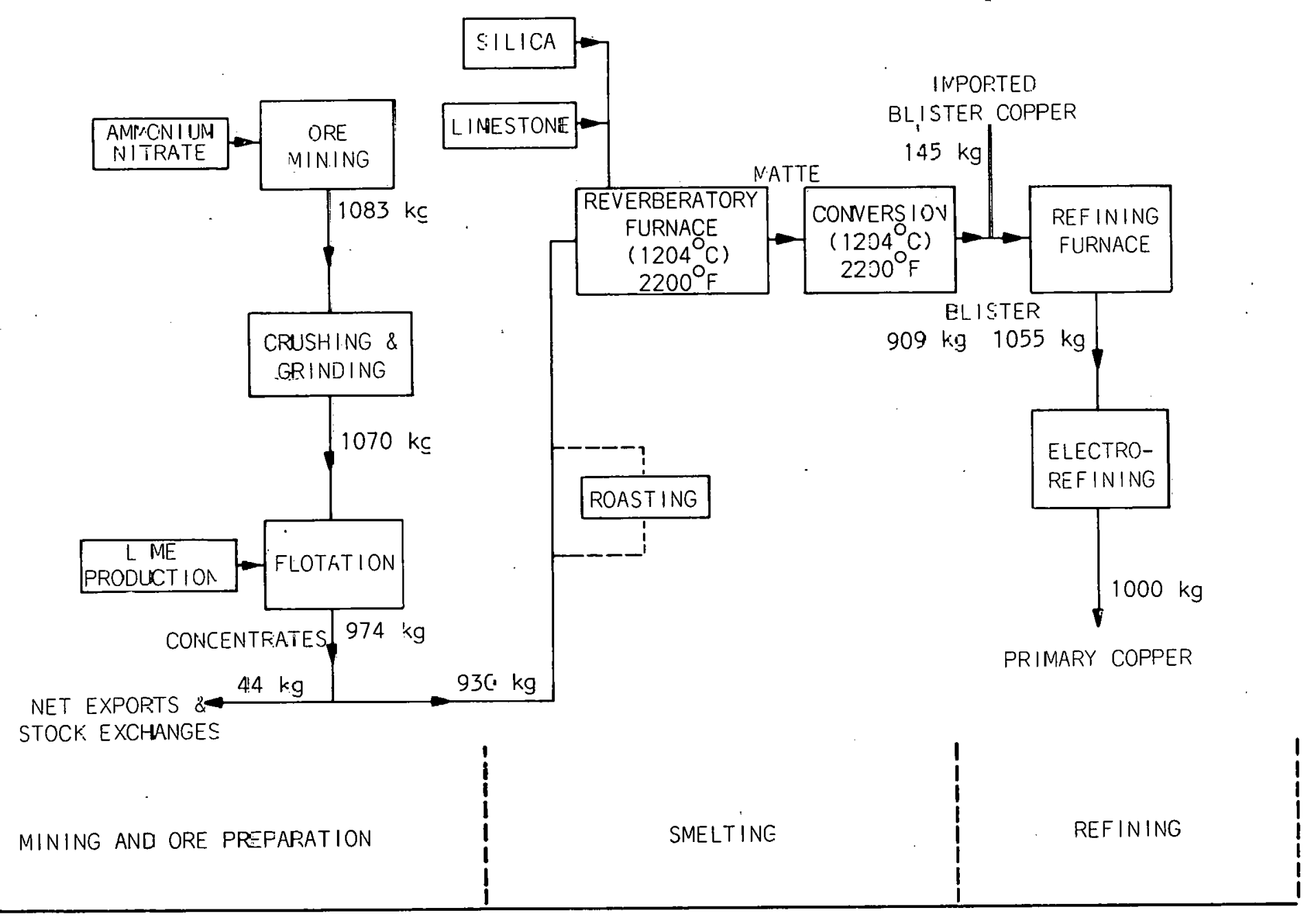

Fig. 4.14. Basic processes in copper productior. 
is a flow sheet of the typical processes used to produce metallic copper from a sulfide ore. The reverberatory furnace and converter are the largest natural gas consumers. Required temperatures are outside the CCC capabilities. More detailed descriptions of the mechanics of the processes are provided in Refs. $I I$ and 20.

Electrically produced shaft power is used to produce compressed air and to drive crushers, ball mills, classifiers, flotation cells, pumps, and subsurface mining equipment. Obviously, all these requirements can be met with in-house CCC systems. Smelting can be accomplished in electric furnaces; economic considerations govern the methods used to provide the energy required by this process phase.

Final purification. (refining) requires melting impure metallic copper produced by smelting to produce anodes for the electrolytic cells. Melting can be accomplished electrically; hypothetically, CCC systems are technologically capable of producing all the energy needed for refining.

\subsubsection{Chemical industry}

The chemical industry is very diverse, with over 11,000 plants of. 1,300 companies which produce over 10,000 products. ${ }^{3}$ Ten major fourdigit SIC groups have been identified as accounting for $290 \%$ of the total energy use for SIC 28. Within these ten groups are approximately 1900 plants. These ten industries are listed:

1. SIC 2812 - Alkalies and chlorine,

2. SIC 2816 - Inorganic pigments,

3. SIC 2819 - Industrial inorganic chemicals,

4. SIC 2821 - Plastic materials and resins,

5. SIC 2822 - Synthetic rubber,

6. SIC 2823 - Cellulosic man-made fibers,

7. SIC 2824 - Organic man-made fibers,

8. SIC 2865 - Cyclic intermediates and crudes,

9. SIC 2869 - Industrial organic chemicals,

10. SIC 2871 - Fertilizers. 
Energy consumption rates, forms, and sources have been reported by several authors. As expected, these are not identical. Considering the unavoidable uncertainties and the differences in interpretations associated with the data, collecting and assembling the various listings are well within reasonable tolerances. Table 4.11 shows total consumption rates abstracted from four references. Table 4.12, because it describes energy use as a function of temperature, is used as the basis for estimating the potential for CCC application in chemical processing. Excluding fuels used as feedstock, " $50 \%$ of the fuel is used to produce steam. Of the $1583 \times 10^{12} \mathrm{~kJ}\left(1500 \times 10^{12} \mathrm{Btu}\right)$ of steam generation, $\sim 13 \%$ is produced in waste heat boilers. Over $90 \%$ of the steam is generated at over $204^{\circ} \mathrm{C}$ $\left(100^{\circ} \mathrm{F}\right)$, but much is used at under $149^{\circ} \mathrm{C}\left(300^{\circ} \mathrm{F}\right)$. This temperature distribution of generated and utilized steam is shown in Table 4.13.

Table 4.11. Estimates of annual energy consumption by the chemical process. industries

\begin{tabular}{|c|c|c|c|}
\hline Source & Year & $\begin{array}{l}\text { Energy consumption } \\
{\left[10^{15} \mathrm{~kJ}\left(10^{15} \mathrm{Btu}\right)\right]}\end{array}$ & Remarks \\
\hline Ref. 22 & 1971 & $2.93(2.78)$ & Purchased energy; excludes feedstock \\
\hline Ref. 8 & 1973 & $4.85(4.60 \pm 10 \%)$ & Includes feedstock energy \\
\hline Ref. 8 & 1973 & $2.81(2.66)$ & Excludes feedstock energy \\
\hline Ref. 23 & 1971 & $2.28(2.16)$ & $\begin{array}{l}\text { Excludes feedstock energy and } \\
\text { purchased electricity }\end{array}$ \\
\hline Ref. 3 & 1971 & $3.20(3.03)$ & $\begin{array}{l}\text { This tabulation used as. basis for } \\
\text { COC potcntial }\end{array}$ \\
\hline
\end{tabular}

In addition to the purchased electricity shown in Table 4.12, about $29.4 \times 10^{9} \mathrm{kWhr}$ is generated yearly in-plant. ${ }^{3}$ About one-half this value is generated via steam drive. On the average, only $22 \%$ of the waste heat from the electricity generation is recovered, although a few plants are recovering up to $45 \% .^{24}$ With $45 \%$ waste heat recovery, the overall fuel utilization for the in-house generation would approach $70 \%$. Implementation of the CCC could make this the rule rather than the exception, with the added benefit of the ability to use coal. 
Table 4.12. Fuel sources, temperature ranges, and energy forms used in the chemical industry in 1971

\begin{tabular}{|c|c|c|c|c|c|c|c|}
\hline \multirow{2}{*}{ Energy form } & \multicolumn{6}{|c|}{$\begin{array}{l}\text { Energy source and amount } \\
{\left[10^{15} \mathrm{~kJ}\left(10^{15} \mathrm{Btu}\right)\right]}\end{array}$} & \multirow{2}{*}{$\begin{array}{l}\text { Percent of } \\
\text { rotal }\end{array}$} \\
\hline & Electricity & Coal & Natural gas & $0 i 1$ & other & Total & \\
\hline Steam & & $0.422(0.400)$ & $0.992(0.940)$ & $0.127(0.120)$ & $0.042(0.040)$ & $1.583(1.500)$ & 50 \\
\hline \multicolumn{8}{|l|}{ Nonsteam } \\
\hline $\begin{array}{l}\mathrm{T}<538^{\circ} \mathrm{C}\left(1000^{\circ} \mathrm{F}\right) \\
\left.\mathrm{T}=538-816^{\circ} \mathrm{C}: 1000-1500^{\circ} \mathrm{F}\right) \\
\mathrm{T}>816^{\circ} \mathrm{C}\left(1500^{\circ} \mathrm{F}\right)\end{array}$ & & & $\begin{array}{ll}0.100(0.095) \\
0.16< & (0.155) \\
0.116 & (0.110)\end{array}$ & $\begin{array}{ll}0.021 & (0.020) \\
0.016 & (0.015) \\
0.021 & (0.020)\end{array}$ & $0.190(0.180)$ & $\begin{array}{ll}0.121 & (0.115) \\
0.369 & (0.350) \\
0.137 & (0.130)\end{array}$ & $\begin{array}{r}4 \\
11 \\
4\end{array}$ \\
\hline Subtotals & & $0.422(0.400)$ & $1.372(1.30)$ & $0.185(0.175)$ & $0.232(0.220)$ & $2.210(2.095)$ & 69 \\
\hline $\begin{array}{l}\text { Purchased electricity } \\
\text { at } 10,000 \mathrm{Btu} / \mathrm{kWhr}\end{array}$ & $0.981(0.930)$ & & & & & $0.981(0.930)$ & 31 \\
\hline Total & & & & . & & $3.191(3.025)$ & 100 \\
\hline Percent of total & 31 & 13 & 43 & 6 & 7 & & \\
\hline
\end{tabular}

Source: Ref. 3 . 
Table 4.13. Steam generation and utilization temperatures in chemical industry

\begin{tabular}{|c|c|c|c|}
\hline $\begin{array}{c}\text { Generation } \\
\text { temperature band } \\
{\left[{ }^{\circ} \mathrm{C}\left({ }^{\circ} \mathrm{F}\right)\right]}\end{array}$ & $\begin{array}{c}\text { Annual steam } \\
\text { generated } \\
{\left[10^{12} \mathrm{~kJ}\left(10^{12} \mathrm{Btu}\right)\right]}\end{array}$ & $\begin{array}{c}\text { Utilization } \\
\text { temperature band } \\
{\left[{ }^{\circ} \mathrm{C}\left({ }^{\circ} \mathrm{F}\right)\right]}\end{array}$ & $\begin{array}{c}\text { Annual steam } \\
\text { utilized } \\
{\left[10^{12^{2}} \mathrm{~kJ}\left(10^{12} \mathrm{Btu}\right)\right]}\end{array}$ \\
\hline $182(<360)$ & $53(50)$ & $163(<325)$ & $463(439)$ \\
\hline $182-274(360-52$ & 1277 (1210) & $163-243(325-470)$ & 1037 (983) \\
\hline $274(>525)$ & $211(200)$ & $243 .(>470)$ & $40(38)$ \\
\hline
\end{tabular}

$a_{\text {Note that steam is usually generated at a higher temperature than is utilized }}$ for process.

Snurce: Ref. 3 .

The CCC system (Tables 4.12 and 4.13) can displace all the gas and oil used for steam generation and probably one-half the oil and gas used for nonsteam heating. This would mean an annual displacement of $\sim 1171 \times$ $10^{12} \mathrm{~kJ}\left(1110 \times 10^{12} \mathrm{Btu}\right)$ of natural gas $\left(1078 \times 10^{9} \mathrm{ft}^{3}\right)$ and $155 \times 10^{12}$ $\mathrm{kJ}\left(147 \times 10^{12} \mathrm{Btu}\right)$ of oil $\left(25 \times 10^{6} \mathrm{bbl}\right)$ using the 1971 figures. CCC systems operating at heat power ratios of 3 to 4 could provide nearly u11 the electical Luad.

The remaining subsections present data for specific subgroups, such as those listed at the beginning of the shemical industry discussion.

4.3.2.1 Alkalies and chlorine. The production of chlorine and caustic soda is examined specifically in this sertinn. Electrolytic manufacture of chlorine and callstir snda requires large amounto of clcc tric power, totaling $\sim 2 \%$ of the total electricity generated in the nation. Nearly $50 \%$ of the electricity is generated at the plant because the large producer can utilize the waste heat (steam) for process energy, mostly in the caustic evaporator that concentrates the dilute $\mathrm{NaOH}$ liquor from the electrolytic ce11. ${ }^{24}$ Most of the chlorine is used in manufacturing chlorinated hydrocarbons for plastic, pesticides, and solvents; uses of caustic soda are numerous.

Electrolytic cells are either the diaphragm or mercury type. The diaphragm cells require less electricity but necessitate the use of evaporators. The basic manufacturing sequence for the diaphragm cell 
is illustrated in Fig. 4.15. Usage of the mercury cell has been declining recently. ${ }^{24}$

Process energy requirements for chlorine/caustic soda manufacture are given in Table 4.14 .

Although cogeneration already exists to a large extent in industry, the fuel used for heat and power is predominantly natural gas ( $280 \%$ of the purchased fuels in 1973). ${ }^{24}$ This accounts for a potential displacement of $26.2 \times 10^{9} \mathrm{~m}^{3}\left(220 \times 10^{9} \mathrm{ft}^{3}\right)$ of gas annually. Petroleum products are used to a lesser extent, $\sim 18 \times 10^{12} \mathrm{~kJ}\left(17 \times 10^{12} \mathrm{Btu}\right)$ in 1973 $\left(2.8 \times 10^{6} \mathrm{bbl} 1\right) .24$

4.3.2.2 Ammonia. Ammonia is produced by the iron-catalyzed reaction between hydrogen and nitrogen. In the United States, virtually all the hydrogen used for ammonia synthesis is obtained by steam-hydrocarbon reforming, using natural gas as the hydrocarbon feedstock. Nitrogen is obtained either from air liquefaction plants or by depleting the oxygen from air introduced into the reformer. ${ }^{6}$ About $80 \%$ of the ammonia produced is used in fertilizers.

Figure 4.16 shows the production procedure for manufacturing ammonia. Modern ammonia plants are engineered for precise temperature control and full reutilization of energy. Exiting gas streams from exothermic reactions are used to (1) heat inlet gas streams prior to reaction, (2) generate steam to run turbines for compression of gases and refrigeration, and (3) transport heat to other parts of the plant. ${ }^{6}$

Process energy loads for ammonia manufacture are listed in Table 4.15.

The steam generation could likely be accomplished by the CCC, but heating the reformer to $816^{\circ} \mathrm{C}\left(1500^{\circ} \mathrm{F}\right)$ may be a borderline application. The fuel presently used is almost exclusively natural gas. With the high waste-heat utilization already in practice, further efforts toward rngeneration may be nonproductive. Furthermore, ammonia plants have been given preference in obtaining natural gas, thus reducing their incentive for fuel conversion. 24

4.3.2.3 Synthetic rubber. Styrene butadiene rubber (SBR) accounts for nearly $60 \%$ of the synthetic rubber produced in the United States. 25 Most of the SBR goes into the manufacture of tires and tire products. 
ORNL-DWG 79-4905 ETD

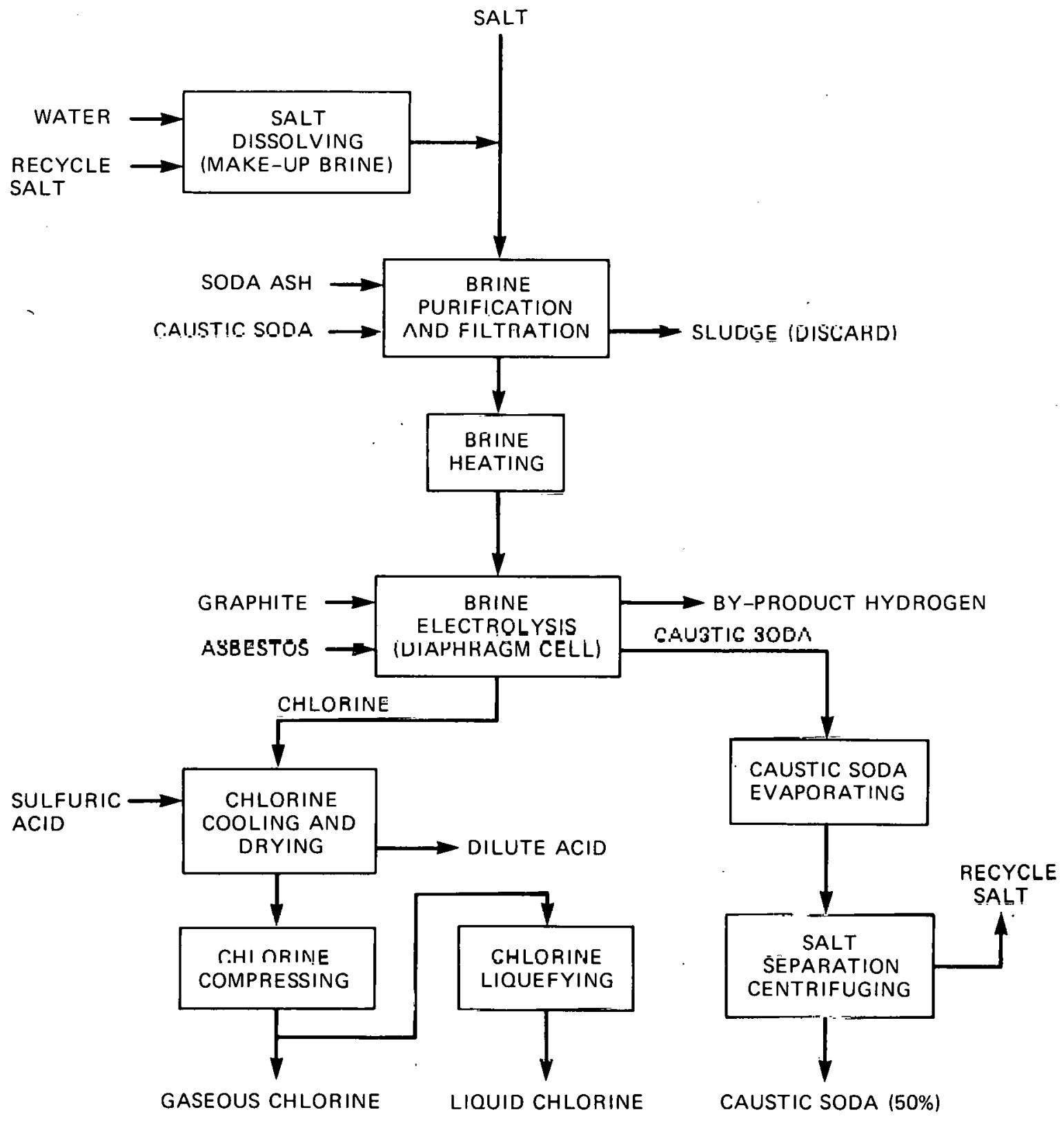

Fig. 4.15. Manufacture of chlorine and caustic soda in a diaphragm cell. 
Table 4.14. Typical process energy consumption in manufacture of chlorine/caustic soda in diaphragm cell ${ }^{\alpha}$

\begin{tabular}{|c|c|c|c|}
\hline Process & $\begin{array}{c}\text { Temperature } \\
{\left[{ }^{\circ} \mathrm{C}\left({ }^{\circ} \mathrm{F}\right)\right]}\end{array}$ & $\begin{array}{c}1974 \operatorname{total}^{b} \text { heat } \\
(\text { steam) } \\
{\left[10^{12} \mathrm{~kJ}\left(10^{12} \text { Btu }\right)\right]}\end{array}$ & $\begin{array}{l}\text { Electricity } \\
\left(10^{9} \mathrm{kWh} r\right)\end{array}$ \\
\hline Brine heating during 'Furification & $66(150)$ & $10.6(10.0)$ & \\
\hline Brire heating & $79-93(175-200)$ & $28.7(27.2)$ & \\
\hline Evaporation to $50 \% \mathrm{NaOH}$ & $143-149(290-300)$ & $175.1(166.0)$ & \\
\hline Cell & & & $41.8-51.6$ \\
\hline
\end{tabular}




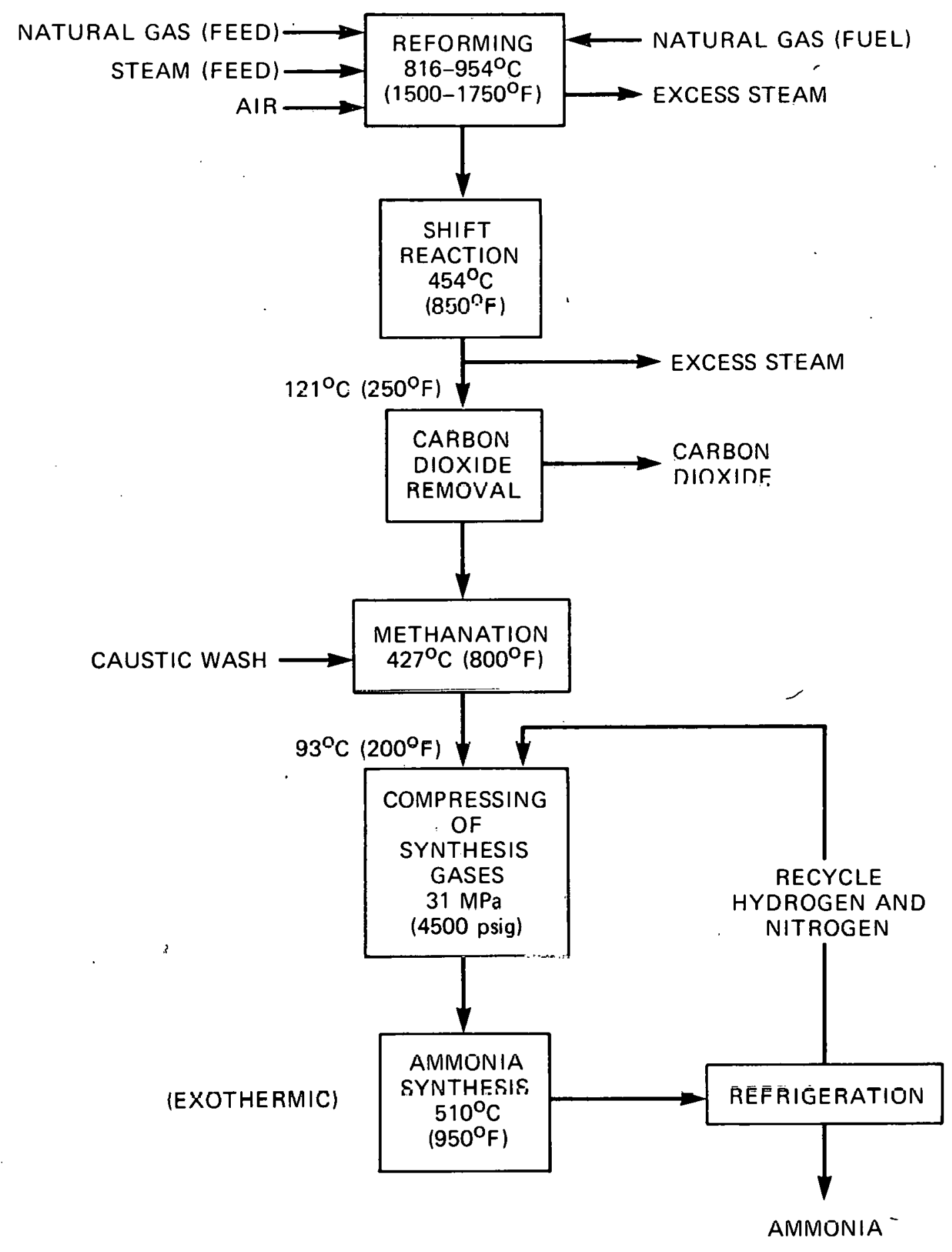

Fig. 4.16. Production of ammonia. 
Table 4.15. Process energy for ammonia production ${ }^{a}$

\begin{tabular}{|c|c|c|}
\hline $\begin{array}{l}\text { Process energy } b \\
{\left[10^{12} \mathrm{~kJ}\left(10^{12} \mathrm{Btu}\right)\right]}\end{array}$ & $\begin{array}{c}\text { Feedstock energy } \\
{\left[10^{12} \mathrm{~kJ}\left(10^{12} \mathrm{Btu}\right)\right]}\end{array}$ & $\begin{array}{l}\text { Electricity } \\
\left(10^{9} \mathrm{kWh} r\right)\end{array}$ \\
\hline 273 (259) & $382(362)$ & 0.93 \\
\hline $\begin{array}{l}a_{\text {For centrifugal }} \\
b \text { Includes proces } \\
\text { erator; based on } 1975 \\
\left(15.8 \times 10^{6} \text { tons) (Re }\right.\end{array}$ & $\begin{array}{l}\text { ompressor plant, Ref. } \\
\text { heat for reformer and } \\
\text { roduction of } 14.3 \text { met } \\
6) \text {. }\end{array}$ & $\begin{array}{l}24 . \\
\text { steam gen- } \\
\text { ic tons }\end{array}$ \\
\hline
\end{tabular}

In general terms, SBR is produced by the emulsion polymerization, which involves mixing the two monomers, styrene and butadiene, in an emulsion reactor with water, catalyst, emulsifier, and other modifiers. Cold SBR is produced by polymerization at $5.0^{\circ} \mathrm{C}\left(41^{\circ} \mathrm{F}\right)$, and, because of its superior properties, it accounts for $275 \%$ of all SBR production.

Production processes for SBR are shown in Fig. 4.17 (Ref.6). Energy requirements are provided in Table 4.16. Process heat is required in the form of steam. The fuel for process heat is essentially all natural gas at the SBR plant. ${ }^{25}$ This fact, coupled with a high $\mathrm{kWhr} / \mathrm{ton}$ figure make SBR plants candidates for the CCC system. Potential displacement of natural gas would be $0.16 \times 10^{9} \mathrm{~m}^{3}\left(5.6 \times 10^{9} \mathrm{ft}^{3}\right)$ annually.

4.3.2.4 Selected plastics. Four plastics materials account for over $60 \%$ of the tutal plastics production: (1) low-density polyethylene (LDPE), (2) high-density polyethylene (HDPE), (3) polystyrene, and (4) polyvinyl chloride (PVC).

Low-density polyethylene (LDPE) production accounts for $\sim 20 \%$ of the total plastics production and uses $230 \%$ of the U.S. ethylene production. Polymerization is carried out at pressures of 100 to $340 \mathrm{MPa}$ (15, 000 to $50,000 \mathrm{psig}$ ) and temperatures between 149 and $316^{\circ} \mathrm{C}\left(300\right.$ and $\left.600^{\circ} \mathrm{F}\right)$. Generalized production processes are shown in Fig. 4.18; process energy is given in Table 4.17. The process steam is apparently generated by either oil or gas ( $250 \%$ each). ${ }^{26}$ The electricity demand is quite high, resulting in a heat/power ratio of 0.47 , which is outside the performance 


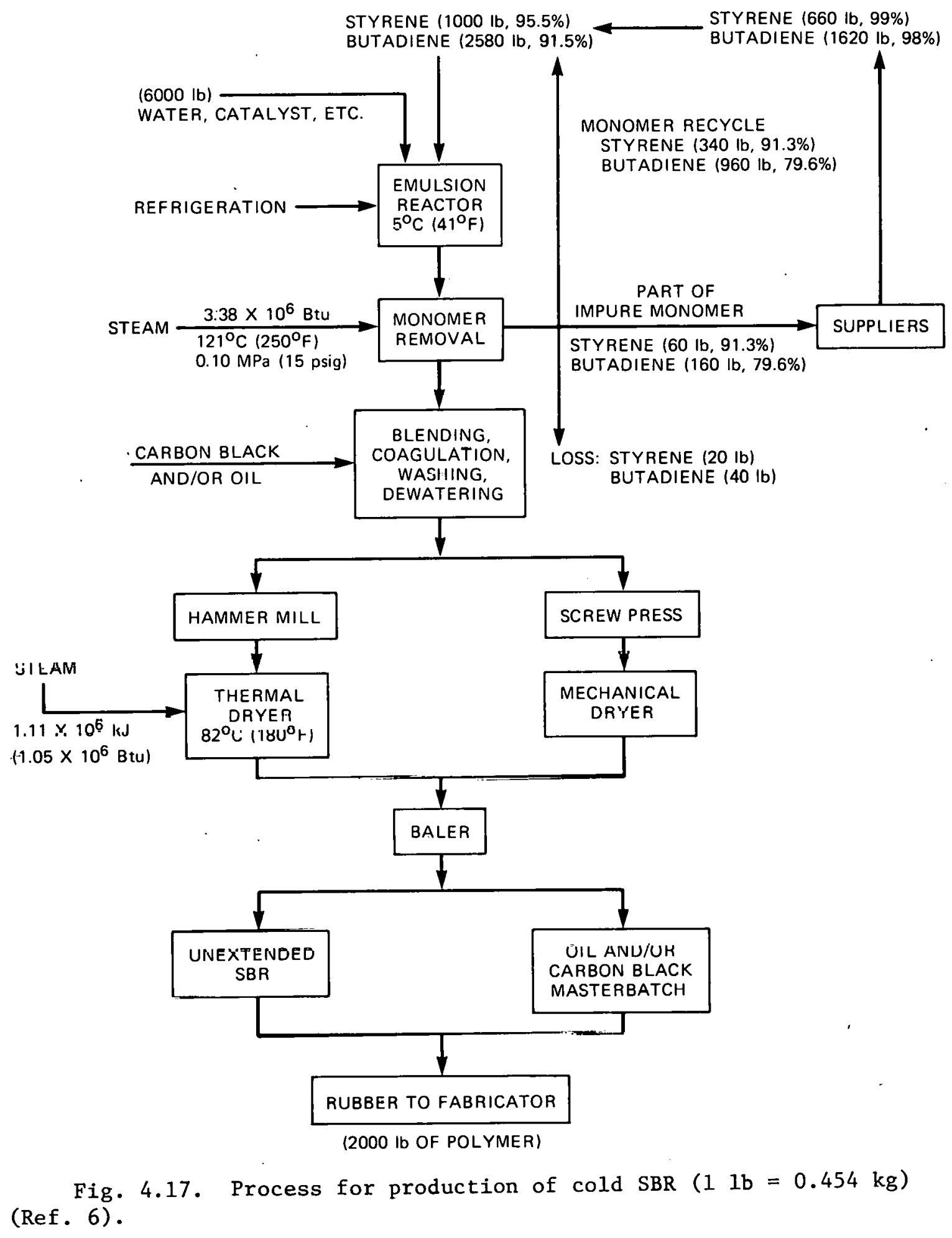




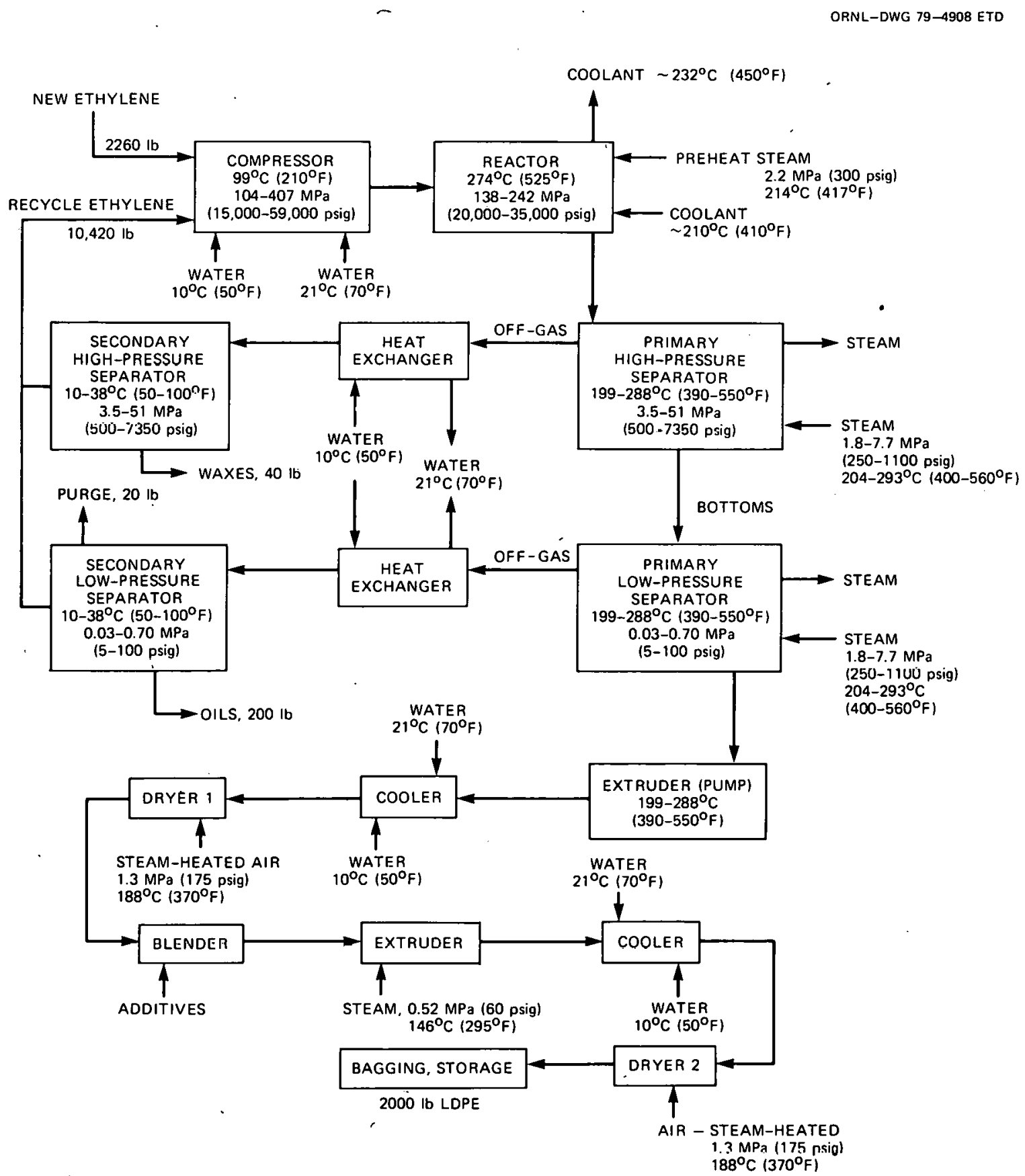

Fig. 4.18. Low-density polyethylene - generalized process $(1 \mathrm{lb}=$ $0.454 \mathrm{~kg})(\operatorname{Ref} .6)$. 
Table 4.16. Process energy consumed in cold SBR production ${ }^{a}$

\begin{tabular}{|c|c|c|}
\hline $\begin{array}{l}\text { Temperature } \\
{\left[{ }^{\circ} \mathrm{C}\left({ }^{\circ} \mathrm{F}\right)\right]}\end{array}$ & $\begin{array}{c}\text { Heat quantity } \\
{\left[10^{12} \mathrm{~kJ}\left(10^{12} \mathrm{Btu}\right)\right]^{b}}\end{array}$ & $\begin{array}{l}\text { Electricity } \\
\left(10^{9} \mathrm{kWh} r\right)\end{array}$ \\
\hline $\begin{array}{l}121(250) \\
104(220)\end{array}$ & $\begin{array}{l}4.67(4.43) \\
1.46(1.38)\end{array}$ & 0.55 \\
\hline $\begin{array}{l}a_{\text {Heat }} \\
\text { tr1c1ty frot } \\
b_{\text {Based }} \\
1.19 \times 10^{6} \\
\text { ally. }\end{array}$ & $\begin{array}{l}\text { temperature from Ref. } \\
\text { f. } 25 \text {. } \\
\text { avesage } 1970-1974 \text { pro } \\
\text { ic tons }\left(1.31 \times 10^{6} \text { t }\right.\end{array}$ & $\begin{array}{l}6 \text {; elec- } \\
\text { duction of } \\
\text { ons) annu- }\end{array}$ \\
\hline
\end{tabular}

capability of the CCC. Depending on the local cost of electricity, implementing the CCC for the electricity may be advantageous, even though the overall fuel utilization might be quite low. Union Carbide Corporation has introduced a low-pressure production method that requires less energy and may be a better candidate for the CCC. ${ }^{27}$

The plastic exhibiting the fastest growth in production is HDPE. Production methods are numerous; the process presented here is the Hoechst slurry process. The process energy required is provided in lable 4.18; the general flow diagram is shown in Fig. 4.12 (Ref. 6). The heat/power ratio makes the process a likely application for the CCC. Presently, the industry uses natural gas (40\%) and fuel oil (60\%) for its process heat. ${ }^{26}$ Implementation of the coal-fired CCC in this industry would displace $0.05 \times 10^{9} \mathrm{~m}^{3}\left(1.9 \times 10^{9} \mathrm{ft}^{3}\right)$ of gas and $0.08 \times$ $10^{6} \mathrm{~m}^{3}\left(0.5 \times 10^{6} \mathrm{bbl}\right)$ oil per year. The electricity in Table 4.18 does not include that required for extrusion and pelletization of the HDPE, which could bring the power demand to $\sim 600 \mathrm{kWhr} / \mathrm{ton}$.

Polyvinily chloride resins averaged $16 \%$ of the total production of all plastics and resin materials between 1969 and $1974 .^{6}$ These resins are produced by suspension, emulsion, bulk, and solution processes, with a suspension polymerization process accounting for $285 \%$ of the U.S. production. Figure 4.20 is a flow chart for the suspension process (Ref. 6). Temperatures and pressures shown are approximate averages of the ranges 
Table 4.17. Process heat in LDPE manufacture

\begin{tabular}{|c|c|c|c|c|c|}
\hline & \multicolumn{3}{|c|}{ Steam per short ton of LDPE } & \multirow{2}{*}{$\begin{array}{l}\text { Process heat } \\
{ }^{a} \\
10^{3} \mathrm{~kJ} / \text { metric ton } \\
\left.\left(10^{3} \mathrm{Btu} / \text { ton }\right)\right]\end{array}$} & \multirow{2}{*}{$\begin{array}{l}\text { Electricity } \\
\text { [kWhr/metric ton } \\
\text { (kWhr/ton)] }\end{array}$} \\
\hline & $\begin{array}{c}\text { Used } \\
{[\mathrm{kg}(\mathrm{Ib})]}\end{array}$ & $\begin{array}{c}\text { Pressure } \\
{[\mathrm{MPa} \mathrm{(psi)]}}\end{array}$ & $\begin{array}{c}\text { Temperature } \\
{\left[{ }^{\circ} \mathrm{C}\left({ }^{\circ} \mathrm{F}\right)\right]}\end{array}$ & & \\
\hline Initiation & $273(600)$ & $2.07(300)$ & $214(417)$ & $810 \quad(699)$ & \\
\hline Primary higl-pressure separator & $114(250)$ & $4.14(600)$ & $252(486)$ & $339(292)$ & \\
\hline Primary low-pressure separator & $68(150)$ & $4.14(600)$ & $252(486)$ & $203(175)$ & \\
\hline Extruder & $136(300)$ & $0.414(60)$ & $146(295)$ & $397(342)$ & \\
\hline Dryer 2 & $45(100)$ & $1.21(175)$ & $188(370)$ & $135(116)$ & \\
\hline Total & & & & $2018(1740)$ & $1201(1090)$ \\
\hline
\end{tabular}

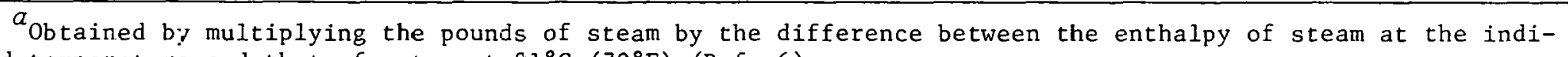
cated temperature and that of water at $21^{\circ} \mathrm{C}\left(70^{\circ} \mathrm{F}\right)(\operatorname{Ref} .6)$. 
Table 4.18. Process energy in HDPE manufacture

\begin{tabular}{|c|c|c|c|c|c|}
\hline & \multicolumn{3}{|c|}{ Steam per sinort ton of $\mathrm{HDPE}$} & \multirow{2}{*}{$\begin{array}{l}\text { Process heat }^{a} \\
{\left[10^{3} \mathrm{~kJ} / \text { metric ton }\right.} \\
\left.\left(10^{3} \mathrm{Btu} / \mathrm{ton}\right)\right]\end{array}$} & \multirow{2}{*}{$\begin{array}{l}\text { Electricity } \\
\text { [kWhr/metric ton } \\
\text { (kWhr/ton)] }\end{array}$} \\
\hline & $\begin{array}{c}\text { Used } \\
{[\mathrm{kg}(1 \mathrm{~b})]}\end{array}$ & $\begin{array}{c}\text { Prəssur } \\
{[M P \exists(p s \bar{i})]}\end{array}$ & $\begin{array}{c}\text { Temperature } \\
\left.\left[{ }^{\circ} \mathrm{C}: \because \mathrm{F}\right)\right]\end{array}$ & & \\
\hline \multicolumn{6}{|c|}{ Huechst slurry process } \\
\hline $\begin{array}{l}\text { Reactor preheat } \\
\text { Steam distillation } \\
\text { Hexane distillatior } \\
\text { Dryer }: \\
\text { Extruder } \\
\text { Dryer } 2\end{array}$ & $\begin{aligned} 250 & (550) \\
318 & (700) \\
45 & (100) \\
227 & (500) \\
136 & (300) \\
45 & (100)\end{aligned}$ & $\begin{array}{l}0.414(6 i) \\
0.414(6 i) \\
0.414(6 i) \\
1.21(17 \vdots) \\
0.414(6 i) \\
1.21(17 \bar{i})\end{array}$ & $\begin{array}{l}146: 295) \\
146: 295) \\
146: 295) \\
188: 370) \\
146: 295) \\
188: 370)\end{array}$ & $\begin{array}{ll}727 & (627) \\
925 & (798) \\
132 & (114) \\
672 & (579) \\
397 & (342) \\
135 & (116)\end{array}$ & \\
\hline Tote1 & & & & $2988(2576)$ & $220(200)$ \\
\hline
\end{tabular}

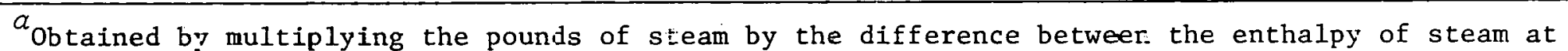
the indicated temperature and that of water at $21^{\circ} \mathrm{C}\left(70^{\circ} \mathrm{F}\right)$ (Ref. 6$)$. 
ORNL-DWG 79-4909 ETD

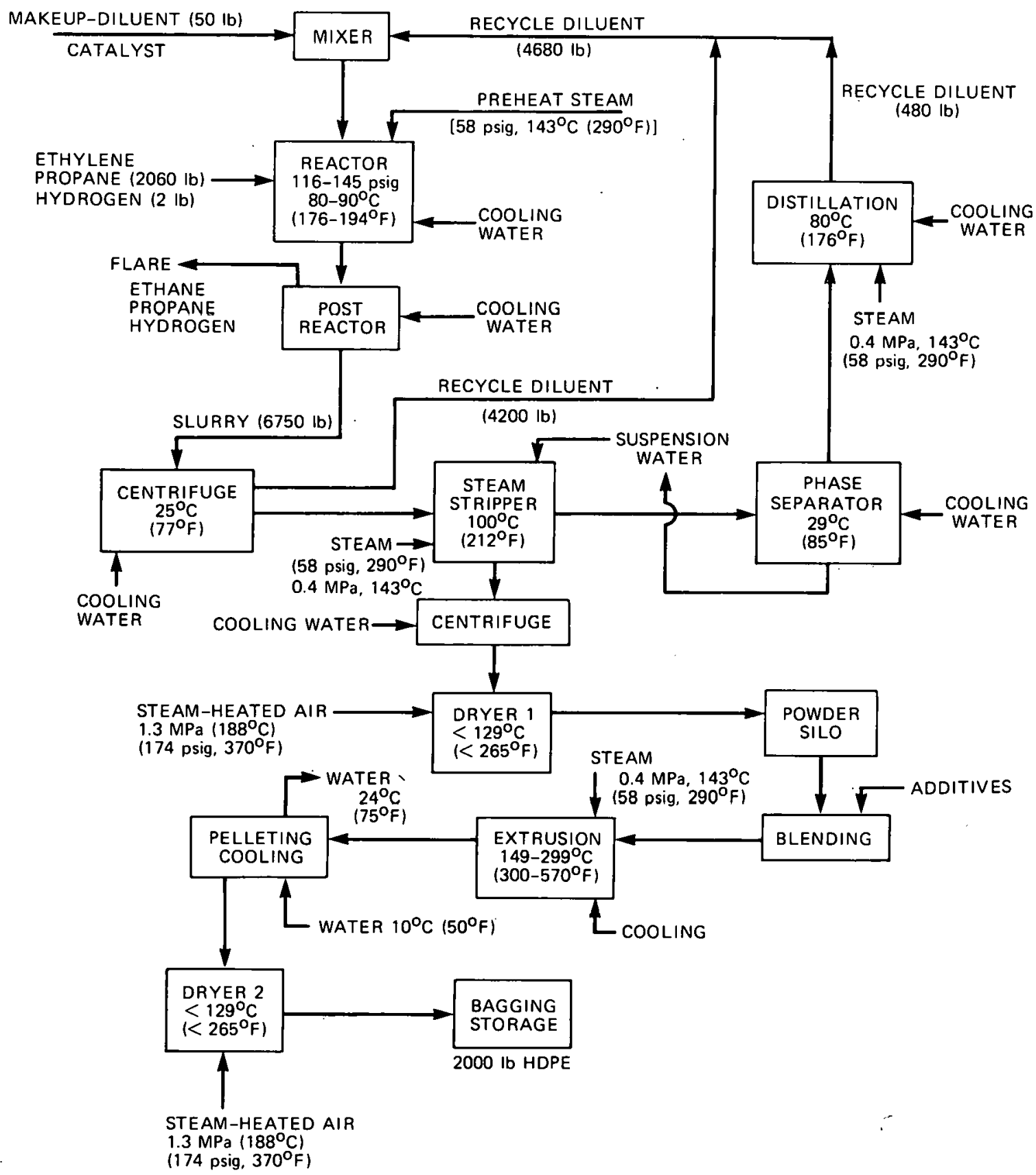

Fig. 4.19. High-density polyethylene - Hoechst slurry process ( $11 \mathrm{~b}=$ $0.451 \mathrm{~kg}$ ) (Ref. 6). 


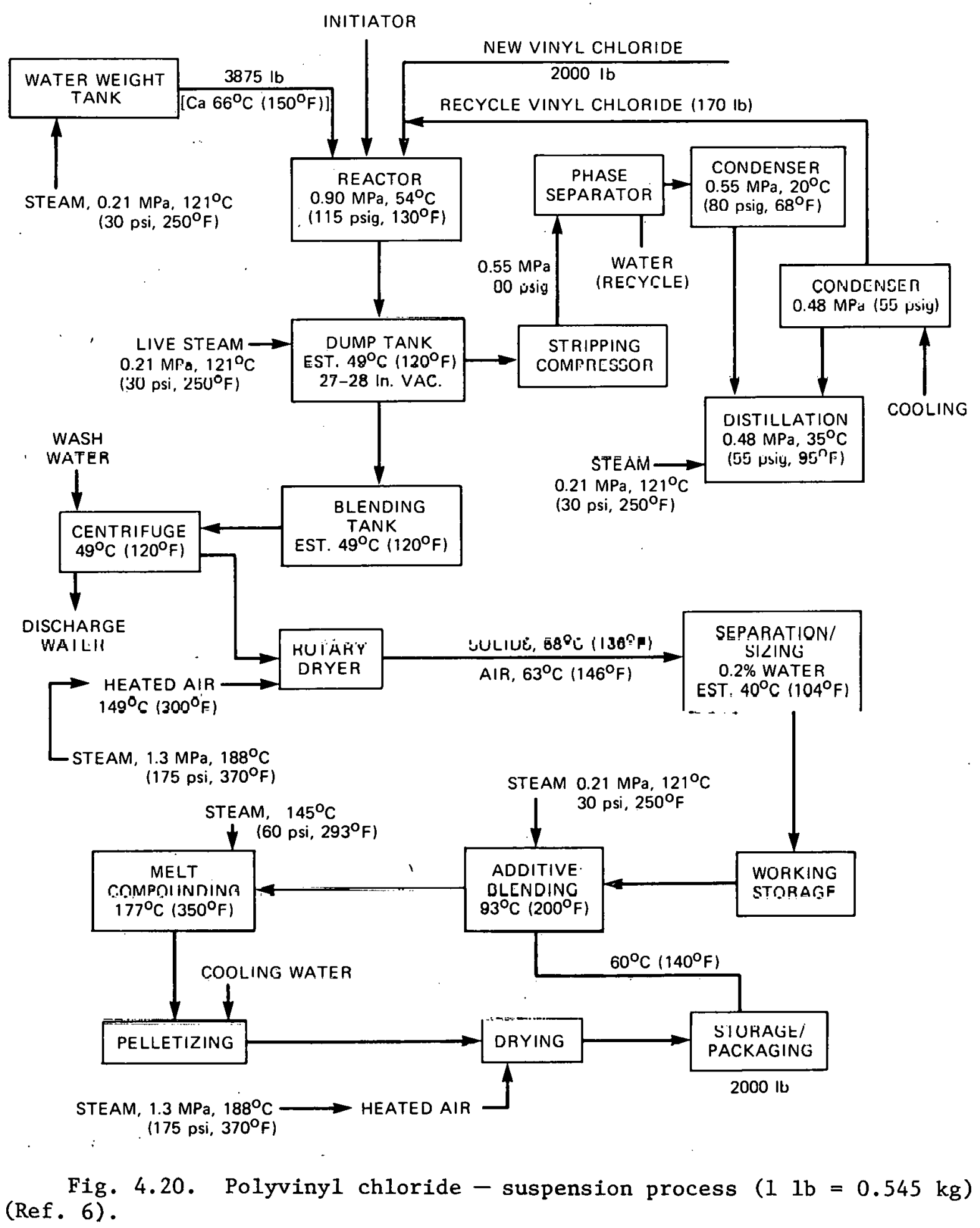


normally expected. The average batch size may produce $\sim 6$ tons of PVC. Energy requirements for production are shown in Table 4.19.

Bulk and solvent processes account for $275 \%$ of polystyrene production. Little detailed information has been published on styrene polymerization because it is generally proprietary. ${ }^{6}$ A schematic of a suspension polymerization process, based on an earlier Battelle report, ${ }^{11}$ is shown in Fig. 4.21 (Ref. 6), and a summary of the process heat consumption is given in Table 4.20. Coal and natural gas account for $240 \%$ each of the purchased fuels for manufacturing polystyrene.

\subsubsection{Petroleum refining}

The petroleum refining industry (SIC 2911) consumes about $12 \%$ of the total energy used by industry in the United States and consists of about 250 refineries belonging to approximately 130 companies. ${ }^{3}$. Total capacity of the refineries approached $27.5 \mathrm{~m}^{3} / \mathrm{sec}\left[15 \times 10^{6} \mathrm{bb} 1\right.$ per calendar day (B/CD)] in $1975 .^{6}$

A complex refinery could consist of about 29 major processes including gas- and oil-fired heaters and mechanical drivers. Except for fired heaters, each of the 28 processes utilizes heat energy supplied internally from fired heaters, indirect steam heaters, or both. ${ }^{6}$ However, in processes such as fluidized-bed catalytic crackers, heat is released during regeneration. Total process heat consumption is estimated to be about $3250 \times 10^{12} \mathrm{~kJ}\left(3100 \times 10^{12} \mathrm{Btu}\right)$ annually, including direct heat and steam. Process temperatures and energy requirements are listed in Table 4.21. Similar information was compiled in Ref. 1. Note that virtually all the heating requirements fall in the range of the CCC useful thermal energy.

A typical refinery may generate up to $55 \%$ of its steam requirements in waste heat boilers in conjunction with the catalytic crackers. ${ }^{28}$ Furthermore, $220 \%$ of the plant's electrical or shaft power requirements are typically generated in-house, the majority in the form of shaft power and almost all from steam turbines. ${ }^{3}$ The electricity demand for a refinery is low relative to the heating requirements; thus the CCC should easily satisfy the entire electrical load. To satisfy the process heat and steam loads would require large units of low electrical 
Table 4.19. Process heat in PVC manufacture

\begin{tabular}{|c|c|c|c|c|c|}
\hline & \multicolumn{3}{|c|}{ Steam per shcrt ton of PVC } & \multirow{2}{*}{$\begin{array}{l}\text { Process ieat } \\
{\left[10^{3} \mathrm{~kJ} / \text { metric ton }\right.} \\
\left.\left(10^{3} \mathrm{Btu} / \text { ton }\right)\right]\end{array}$} & \multirow{2}{*}{$\begin{array}{l}\text { Electricity } \\
{[\mathrm{kWhr} / \mathrm{metric} \text { ton }} \\
(\mathrm{kWhr} / \mathrm{ton})]\end{array}$} \\
\hline & $\begin{array}{c}\text { Used } \\
{[\mathrm{kg}(1 \mathrm{~b} \vdots]}\end{array}$ & $\begin{array}{l}\text { Pressure } \\
{[\mathrm{MPa} \text { (psi)] }}\end{array}$ & $\begin{array}{c}\text { Temperature } \\
{\left[{ }^{\circ} \mathrm{C}\left({ }^{\circ} \mathrm{F}\right)\right]}\end{array}$ & & \\
\hline \multicolumn{6}{|c|}{ Suspension polymerization } \\
\hline Initiaticn & $205(450)$ & $3.207 \quad(30)$ & $121(250)$ & $588(507)$ & \\
\hline Vinyl chloride distillatior & $3.2(7)$ & $3.207,(30)$ & $121(250)$ & $9.3(8)$ & \\
\hline Rotary dryer & $227(500)$ & R. 208 (175) & $188(370)$ & $672(579)$ & \\
\hline Blending & $45(10 C)$ & D. $207(30)$ & $121(250)$ & 131 (1i3) & \\
\hline Melt compounding & $14(25 \mathrm{C})$ & $1) .414(60)$ & $145(293)$ & $342(295)$ & \\
\hline \multirow[t]{2}{*}{ Drying pellets } & $45(100)$ & $1.208(175)$ & $188(370)$ & $135(116)$ & \\
\hline & & & & 1877 (1618) & $485(440)$ \\
\hline
\end{tabular}

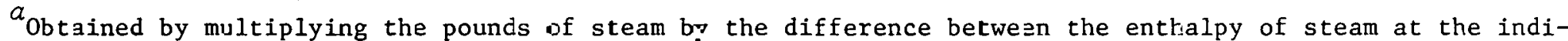
cated temperature and that of water at $21^{\circ} \mathrm{C}\left(0^{\circ} \mathrm{F}\right)$ : Ref. 6). Electricity from Ref. 26 . Coal and natural gas account for $280 \%$ of the fuels usec. ${ }^{26}$ 


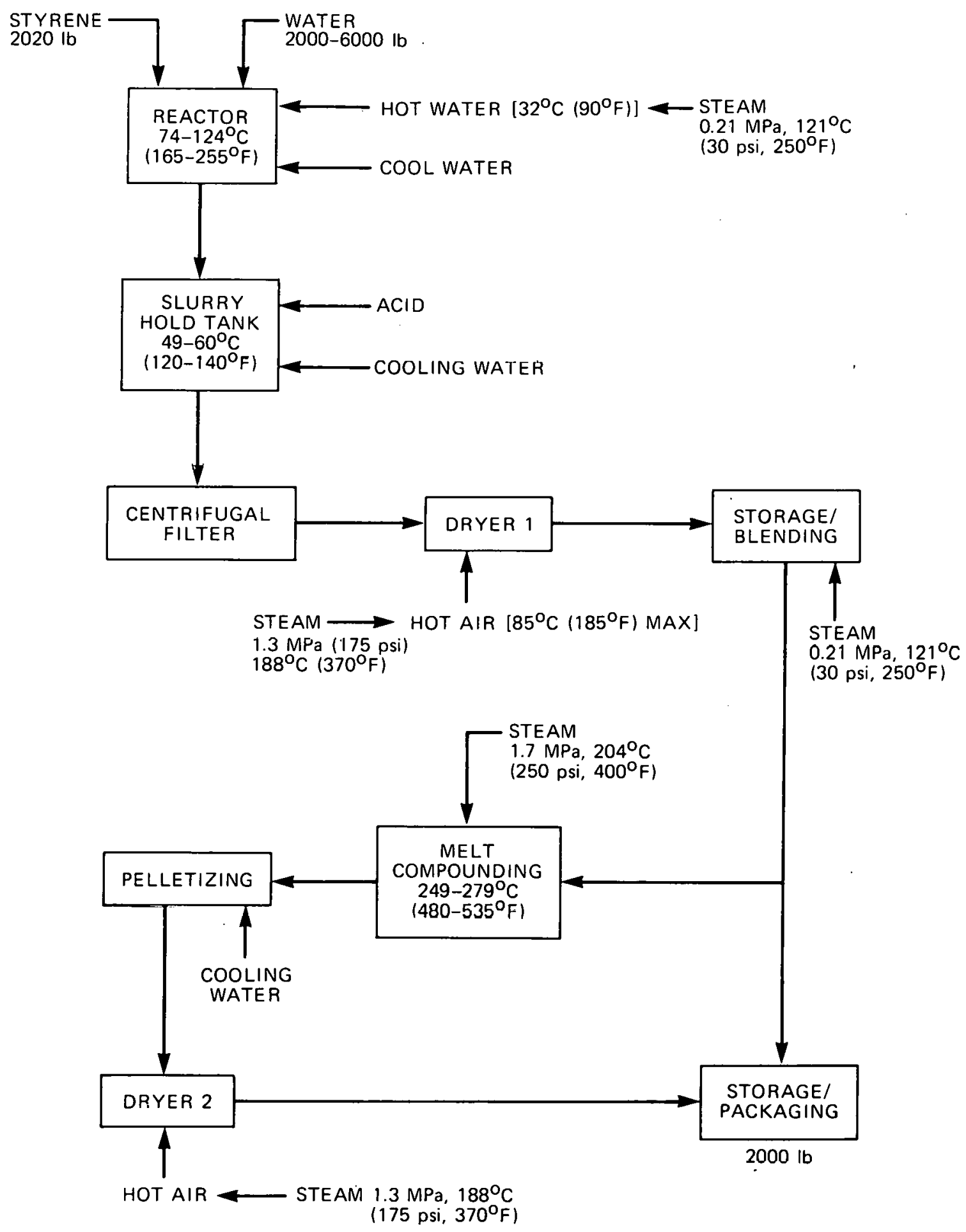

Fig. 4.21. Polystyrene - suspension polymerization ( $11 \mathrm{~b}=0.454 \mathrm{~kg})$ (Ref. 6). 
Table 4.20. Procass heat in polystyrene manufacture

\begin{tabular}{|c|c|c|c|c|c|}
\hline & \multicolumn{3}{|c|}{ Steam per short ton of polystyrene } & \multirow{2}{*}{$\begin{array}{l}\text { Erocess heat } \\
{\left[10^{3} \mathrm{~kJ} / \text { matric ton }\right.} \\
\left.\left(10^{3} \mathrm{Btu} / \text { ton }\right)\right]\end{array}$} & \multirow{2}{*}{$\begin{array}{l}\text { Electricity } \\
\text { [kWhr/metric ton } \\
(\mathrm{kWh} / \text { ton })]\end{array}$} \\
\hline & $\begin{array}{c}\text { Used } \\
{[\mathrm{kg}(1 \mathrm{~b})]}\end{array}$ & $\begin{array}{l}\text { Pressure } \\
{[\text { [.Pa (psi)] }}\end{array}$ & $\begin{array}{c}\text { Temperature } \\
{\left[{ }^{\circ} \mathrm{C}\left({ }^{\circ} \mathrm{F}\right)\right]}\end{array}$ & & \\
\hline \multicolumn{6}{|c|}{ Suspension process } \\
\hline $\begin{array}{l}\text { Reactor (initiation) } \\
\text { Dryer } 1 \text { (air at } 138^{\circ} \mathrm{F} \text { ) } \\
\text { Blending. } \\
\text { Melt compounding } \\
\text { Dryer } 2\end{array}$ & $\begin{aligned} 45 & (100) \\
58 & (150) \\
45 & (100) \\
136 & (300) \\
45 & (100)\end{aligned}$ & $\begin{array}{ll}0.207 & (30) \\
1.208 & (175) \\
0.207 & (30) \\
1.725 & (253) \\
1.208 & (175)\end{array}$ & $\begin{array}{ll}121 & (250) \\
188 & (370) \\
121 & (250) \\
204 & (400) \\
188 & (370)\end{array}$ & $\begin{array}{l}131(113) \\
202(174) \\
131 .(113) \\
405(349) \\
135(116)\end{array}$ & \\
\hline Total & & & & 1003 (865) & $339(308)$ \\
\hline
\end{tabular}

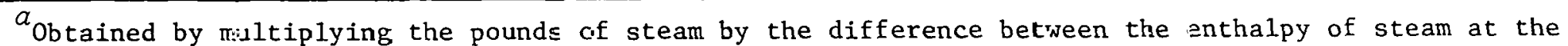
indicated temperature and that of water at $21^{\circ} \mathrm{C}\left(70^{\circ} \mathrm{F}\right)$ (Ref.6). Electricity from Ref. 26. 
Table 4.21. Summary of energy consumed in refinery by process

\begin{tabular}{|c|c|c|c|c|c|c|c|}
\hline \multirow[b]{2}{*}{$\begin{array}{c}\text { Process } \\
-\end{array}$} & \multirow{2}{*}{$\begin{array}{l}\text { Processing } \\
\text { temperature } \\
{\left[{ }^{\circ} \mathrm{C}\left({ }^{\circ} \mathrm{F}\right)\right]}\end{array}$} & \multicolumn{3}{|c|}{ Energy required $^{a}$} & \multirow{2}{*}{$\begin{array}{c}\text { Quantity } b \\
\text { processed } \\
{\left[10^{9} \mathrm{~m}^{3} / \text { year }\right.} \\
\left.\left(10^{9} \mathrm{bb} 1 / \text { year }\right)\right]\end{array}$} & \multicolumn{2}{|c|}{$\begin{array}{c}\text { Process heat total } \\
{\left[10^{12} \mathrm{~kJ} / \text { year }\right.} \\
\left.\left(10^{12} \mathrm{Btu} / \text { year }\right)\right]\end{array}$} \\
\hline & & $\begin{array}{l}\text { Electrical- } \\
\text { nechanical } \\
{\left[\mathrm{kWhr} / \mathrm{m}^{3}\right.} \\
(\mathrm{kWhr} / \mathrm{bb} 1)]\end{array}$ & {$\left[\mathrm{kg} / \mathrm{m}^{3}(1 \mathrm{~b} / \mathrm{bt} 1)\right]$} & $\begin{array}{c}\text { Fired heat } \\
{\left[1000 \mathrm{~kJ} / \mathrm{m}^{3}\right.} \\
(1000 \mathrm{Btu} / \mathrm{bb} 1)]\end{array}$ & & Steam & Direct heat \\
\hline Desalting & & $0.06(0.01)$ & $63(22)$ & $0(0)$ & $0.865(5.44)$ & $127(120)$ & \\
\hline Crude distillation & $343(650)$ & $3.1(0.5)$ & $43(15)$ & $464(70)$ & $0.865(5.44)$ & $87(82)$ & $401(380)$ \\
\hline Vacuum distillation & $416(780)$ & $1.3(0.2)$ & $51(18)$ & $199(30)$ & $0.313(1.97)$ & $3.7(3.5)$ & $62(59)$ \\
\hline Chemical sweetening & & $0.06(0.01)$ & $0(0)$ & $0(0)$ & & & \\
\hline Hydrogen generation & $538(1000)$ & $3.1(0.50)$ & $0(0)$ & $663(100)$ & NA & & \\
\hline $\begin{array}{l}\text { Néphtha hydrogen } \\
\text { treating }\end{array}$ & $427(800)$ & $8.8(1.4)$ & $229(80)$ & $332(50)$ & & & $\cdot$ \\
\hline $\begin{array}{l}\text { Kerosene hydrogen } \\
\text { treating }\end{array}$ & $427(800)$ & $10.0(1.6)$ & $23(8)$ & $464(70)$ & & & \\
\hline $\begin{array}{l}\text { Gas oil hydrogen } \\
\text { treating }\end{array}$ & $427(800)$ & $12.6(2)$ & $29(10)$ & $464(70)$ & $0.286(1.80)$ & $57(54)^{c}$ & $133(126)^{c}$ \\
\hline $\begin{array}{l}\text { Lubricating oil } \\
\text { hydrogen treating }\end{array}$ & $427(800)$ & $37.7(6)$ & $71(25)$ & $663(100)$ & 1 & & \\
\hline $\begin{array}{l}\text { Residual oil hydrogen } \\
\text { treating }\end{array}$ & $454(850)$ & 18.8 (3) & $71(25)$ & $531(80)$ & & & . \\
\hline Catalytic hydrocracking & $427(800)$ & $31.4(5)$ & $51(18)^{d}$ & $1327(200)$ & $0.496(3.12)$ & $59(56)$ & $658(624)$ \\
\hline Gas processing & & $12.6(2)$ & $172(60)$ & $0(0)$ & NA & & \\
\hline Anine stripping & & $3.1(0.5)$ & $3(1)$ & $0(0)$ & . NA & & \\
\hline Sulfur manufacture & $176(350)$ & $0.63(0.1)$ & $11(4)$ & $3(0.4)$ & NA & & \\
\hline Isomerization & $260(500)$ & $7.5(1.2)$ & $57(20)$ & $199(30)$ & $0.03(0.17)$ & $3.6(3.4)$ & $3.7(3.5)$ \\
\hline Catalytic reforming & $538(1000)$ & 31.4 (5) & $0(0)$ & $1992(300)$ & $0.20(1.25)$ & & $395(374)$ \\
\hline
\end{tabular}


Table 4.21 (continued)

\begin{tabular}{|c|c|c|c|c|c|c|c|}
\hline \multirow{2}{*}{ Process } & \multirow{2}{*}{$\begin{array}{c}\text { Processing } \\
\text { temperature } \\
{\left[{ }^{\circ} \mathrm{C}\left({ }^{\circ} \mathrm{F}\right)\right]}\end{array}$} & \multicolumn{3}{|c|}{ Energy required $^{a}$} & \multirow{2}{*}{$\begin{array}{c}\text { Quant:ty } \\
\text { processed } \\
{\left[10^{9} \mathrm{~m}^{3} \text { :yeaz }\right.} \\
\left.\left(10^{9} \text { bbliyear }\right)\right]\end{array}$} & \multicolumn{2}{|c|}{$\begin{array}{c}\text { Process heat total } \\
{\left[10^{12} \mathrm{~kJ} / \text { year }\right.} \\
\left.\left(10^{12} \mathrm{Btu} / \text { year }\right)\right]\end{array}$} \\
\hline & & $\begin{array}{l}\text { Electric }{ }^{2}- \\
\text { mechanic }{ }^{\prime} 1 \\
{\left[\mathrm{kWhr} / \mathrm{m}^{\Xi}\right.} \\
(\mathrm{kWhr} / \mathrm{bbl})]\end{array}$ & {$\left[\mathrm{kg} / \mathrm{m}^{3}(1 \mathrm{~b} / \mathrm{bb} 1)\right]$} & $\begin{array}{c}\text { Fired heat } \\
{\left[1000 \mathrm{~kJ} / \mathrm{m}^{3}\right.} \\
(1000 \mathrm{Btu} / \mathrm{bbl}]\end{array}$ & & Steam & Direct heat \\
\hline $\begin{array}{l}\text { Fluid-bed catalytic } \\
\text { cracking }\end{array}$ & $\begin{array}{l}510(950 i \\
649(1200)\end{array}$ & 18.8 (3) & $114(40)^{d}$ & $465(70)$ & $0.67(4.2)$ & $177(168)$ & $309(293)$ \\
\hline $\begin{array}{l}\text { Moving-bed catalytic } \\
\text { cracking }\end{array}$ & $493(920 i$ & $6.3(1.13)$ & $286(100)^{d}$ & $1992(300)$ & $0.09(0.54)$ & $57(54)$ & $171(162)$ \\
\hline Visbreaking & $523\left(\exists 75^{\circ}\right.$ & $11.3(1.3)$ & $0(0)^{d}$ & $1726(260)$ & $0.08(0.51)$ & & $139(1 \Xi 2)$ \\
\hline Coking & $565(1050)$ & $94.2\{15 !$ & $0(0)^{d}$ & $2324(350)$ & $0.17(1.09)$ & & $402(3 \varepsilon 1)$ \\
\hline Catalytic folymerization & $188(370)$ & $7.5(1.2)$ & $57(20)$ & $0(0)$ & NA & & \\
\hline Cataly_tic alkylation & $149(300)$ & $50.2(8)$ & $572(200)$ & $0(0)$ & $0.05(0.3)$ & $53(50)$ & \\
\hline Asphalt pracessing & $260(500)$ & $12.6 \quad(2)$ & $286(100)$ & $1328(200)$ & $0.04(0.26)$ & $27(26)$ & $56(53)$ \\
\hline Storage and blending & & $0.06(0.01)$ & $3(1.0)$ & $0(0)$ & & & \\
\hline \multicolumn{8}{|l|}{$\begin{array}{l}\text { Prime movers electric } \\
\text { steam IC }\end{array}$} \\
\hline \multicolumn{8}{|l|}{ Steam generation } \\
\hline \multicolumn{8}{|l|}{ Process heaters } \\
\hline Total & & & & & & $675(640)$ & $2729(2587)$ \\
\hline
\end{tabular}

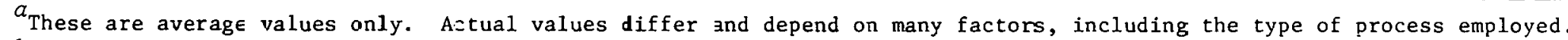

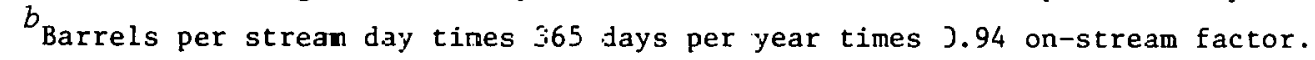

${ }^{c}$ Based on total catalytic hydrrtreated volume and mean of $13.6 \mathrm{~kg}(30 \mathrm{lb})$ steam and $73.5 \times 10^{3} \mathrm{~kJ}\left(70 \times 10^{3} \mathrm{Btu}\right) \mathrm{fired}$ heat per barrel.

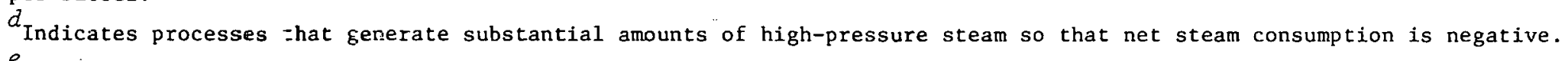

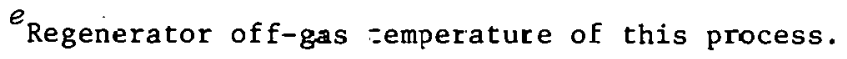


output, which might prove uneconomical compared to other heating means. However, not all the process heating and steam generation is accomplished by fuels purchased specifically for such. By-product and internally. generated fuels are used to a great extent.

Three major fuel sources are evident in the petroluem refining industry. Petroleum products account for over one-half the energy requirements for the industry; ${ }^{3}$ this is generally called captive energy. Refinery gases are considered as residual products because they must be produced in the processes. However, they involve a mass loss from the crude oil which, along with the money spent on processing, makes these quite expensive. $^{3}$ Because they have a market value, oil fuels and liquefied petroleum gas (LPG) are considered as purchased fuels. The valuable LPG is burned since there is no way to store it under pressure to meet the seasonal demand. ${ }^{3}$ Natural gas is the other major source of energy, accounting for $34 \%$ of total fuels on a national average. ${ }^{3}$ Coal use is very small at this time.

The fuels used to raise steam and those burned for direct heat are listed in Tables 4.22 and 4.23, respectively. A breakdown of the electrical and mechanical power consumption is presented in Table 4.24.

The potential for fuel displacement by coal may be ascertained from the data in Tables 4.22 and 4.23. The CCC useful thermal energy is capable

Table 4.22. Fuels utilized for steam generation in petroleum refining - 1974

\begin{tabular}{|c|c|c|}
\hline Fuel & $10^{12} \mathrm{~kJ}\left(10^{12} \mathrm{Btu}\right)$ & $\begin{array}{l}\text { Percent of } \\
\text { total }\end{array}$ \\
\hline $\begin{array}{l}\text { Coal } \\
\text { Oils } \\
\text { Natural gas and LPG } \\
\text { Refinery gas } \\
\text { Coke }\end{array}$ & $\begin{aligned} 82.0 & (77.7) \\
266.8 & (252.9) \\
262.0 & (248.3)\end{aligned}$ & $\begin{array}{c}0 \\
13.4 \\
43.7 \\
42.9 \\
0\end{array}$ \\
\hline Total & $610.8(578.9)$ & 100 \\
\hline
\end{tabular}

Source: Ref, 3 , 
Table 4.23. Fuels used for nonsteam heat in petroleum refining $-1974\left[10^{12} \mathrm{~kJ}\left(10^{12} \mathrm{Btu}\right)\right]$

\begin{tabular}{|c|c|c|c|}
\hline \multirow{2}{*}{ Fuel } & \multicolumn{3}{|c|}{$\begin{array}{c}\text { Temperature band } \\
{\left[{ }^{\circ} \mathrm{C}\left({ }^{\circ} \mathrm{F}\right)\right]}\end{array}$} \\
\hline & $149(<300)$ & $149-538(300-1000)$ & $538-816(1000-1500)$ \\
\hline $\begin{array}{l}\text { Oils } \\
\text { Natural gas and L̀P } \\
\text { Refinery gas } \\
\text { Coke }\end{array}$ & $\begin{array}{ll}23.2 & (22.0) \\
84.3 & (79.9) \\
80.1 & (75.9)\end{array}$ & $\begin{array}{ll}187.3 & (177.5) \\
644.3 & (610.7) \\
610.4 & (578.6)\end{array}$ & $\begin{aligned} 38.3 & (36.3) \\
36.5 & (34.6) \\
257.3 & (2 / 3.9)\end{aligned}$ \\
\hline Total & $187.6(177.8)$ & $1442.0(1366.8)$ & $332.1(314.8)$ \\
\hline
\end{tabular}

Source: Ref. 3 .

Table 4.24. Electrical/mechanical power used in petroleum reflning - 1974

\begin{tabular}{|c|c|}
\hline Source & $10^{9} \mathrm{kWhr}$ \\
\hline Findliased eleclalcloy & 19.63 \\
\hline $\begin{array}{c}\text { In-plant } \\
\text { Nonsteam } \\
\text { Electric } \\
\text { Shaft }\end{array}$ & $\begin{array}{l}0.097 \\
0.66\end{array}$ \\
\hline $\begin{array}{l}\text { In-plant } \\
\text { Steam } \\
\text { Electric } \\
\text { Shaft }\end{array}$ & $\begin{array}{l}1.34 \\
3.33\end{array}$ \\
\hline Total & 25.06 \\
\hline
\end{tabular}

Source: Ref. 3 .

of generating all steam at the required temperature and can conservatively generate direct heat up to $538^{\circ} \mathrm{C}\left(1000^{\circ} \mathrm{F}\right)$ while producing some electric power. Although direct coal-fired heaters or steam generators (without a power system) may be more feasible in some cases, the potential for conversion to coal still exists. This potential amounts to $26.8 \times 10^{9} \mathrm{~m}^{3}$ $\left(240 \times 10^{9} \mathrm{ft}^{3}\right)$ of natural gas and $2.1 \times 10^{6} \mathrm{~m}^{3}\left(13 \times 10^{6} \mathrm{bbl}\right)$ of oil 
for steam generation with an additional $18.7 \times 10^{9} \mathrm{~m}^{3}\left(660 \times 10^{9} \mathrm{ft}^{3}\right)$ of gas and $5.4 \times 10^{6} \mathrm{~m}^{3}\left(34 \times 10^{6} \mathrm{bbI}\right)$ oil used for nonsteam heating. Individual process descriptions can be found in the literature ${ }^{7,28}$ and are not included in this section.

\subsubsection{Paper and pulp industry}

The paper and allied products industry (SIC 21) includes pulp, paper, and paperboard making, conversion of paper and board into finished products, and making building paper and board. Pulp, paper, and paperboard manufacturing (SIC 261, 262, 263) account for $86 \%$ of the fuel utilized by SIC $26 .{ }^{6}$ The pulp and paper industry (primary products) comprises some 350 companies operating over $700 \mathrm{mills}^{3}$ Over two-thirds of the U.S. production capacity consists of integrated mills that have both pulping and paper-making facilities on-site. ${ }^{3}$ Although smaller in size, the number of nonintegrated paper mills is about the same as the integrated plants. 6

Four principal processes are used to produce most of the wood pulp: groundwood (mechanical), Kraft, sulfite, and semichemical. Use of the sulfite process has declined to $\sim 5 \%$ of the production. ${ }^{6}$ Production of pulp and paper is summarized in Table 4.25, and Fig. 4.22 depicts the

Table 4.25. Pulp, paper, and paper board production

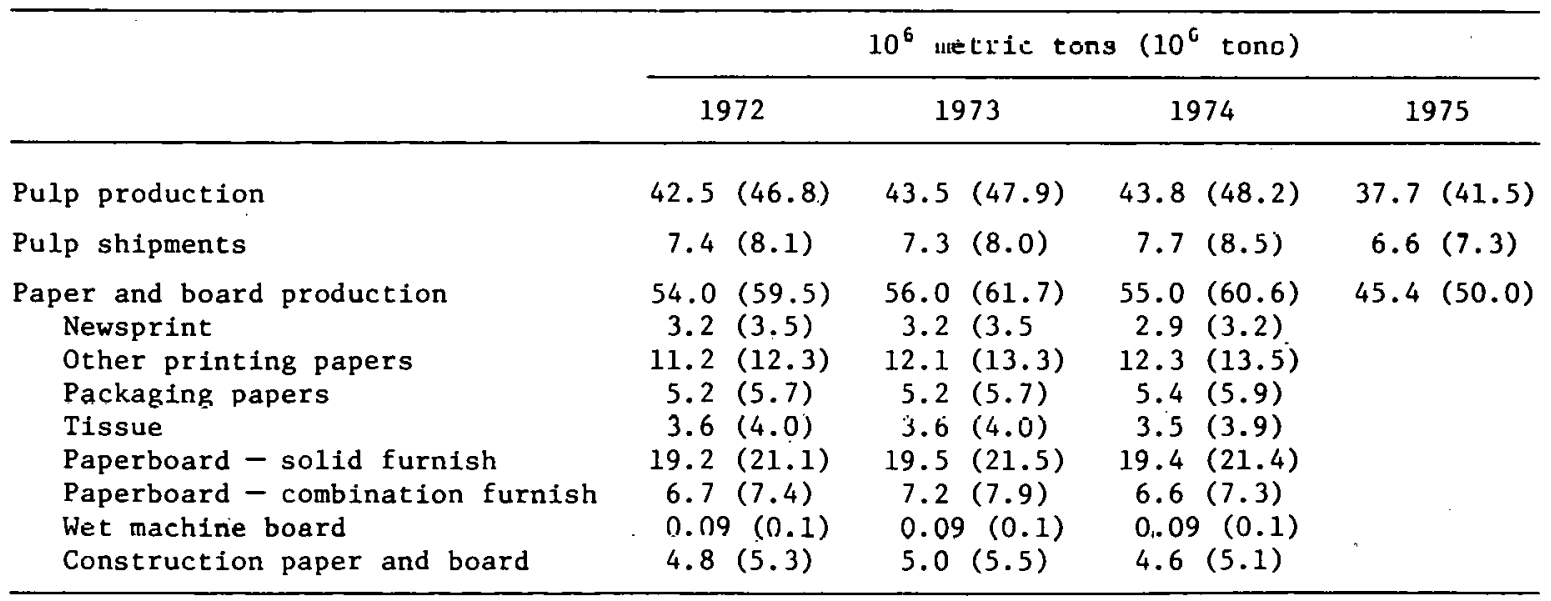

Source: $\operatorname{Ref} .6$. 
ORNL-DWG 79-4912 ETO

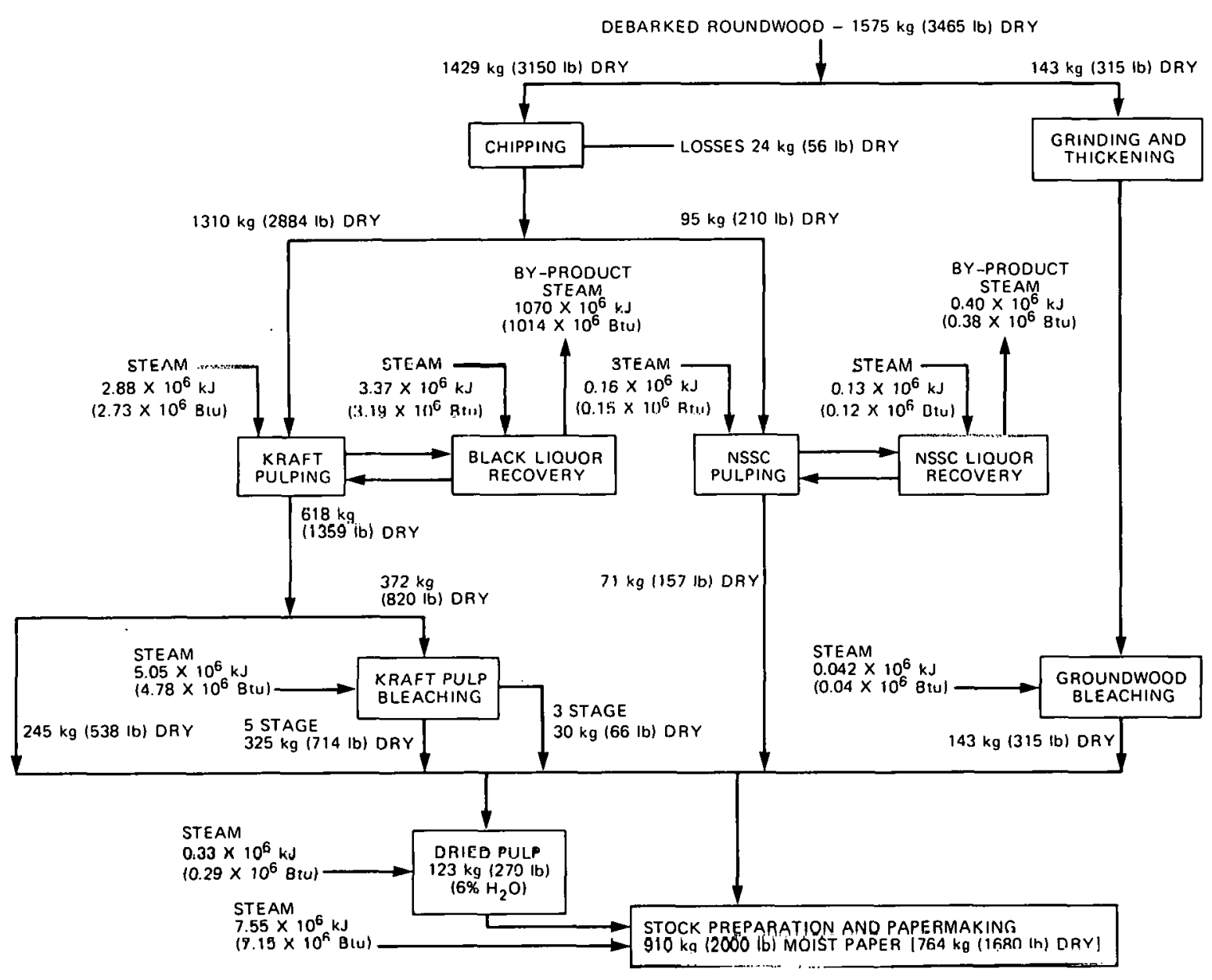

Fig. 4.22. Overall steam and materials flow for pulp and paper industry $(1 \mathrm{lb}=0.454 \mathrm{~kg}, 1 \mathrm{Btu}=1.055 \mathrm{~kJ})($ Ref. 6).

processes in the industry. Descriptions of the various processes are availahle in Refs. 6 and 29 .

The pulping and paper production require considerable amounts of steam, heat, and electricity. In estimating the potential for fuel conversion to coal, the contribution of by-product fuels, which is substantial, must be considered. Fuels used to generate steam are listed in Table 4.26, and steam requirements for the various processes are summarized in Table 4.27 . 
Table 4.26. Fuels consumed for steam generation in pulp and paper industry - 1975

\begin{tabular}{lrr}
\hline Fuel & $10^{12} \mathrm{~kJ}\left(10^{12}\right.$ Btu $)$ & $\begin{array}{r}\text { Percent of } \\
\text { total. }\end{array}$ \\
\hline Coal & $200(190)$ & 10.9 \\
Fuel oils & $459(435)$ & 25.0 \\
Natural gas & $295(280)$ & 16.0 \\
Bark and wood & $148(140)$ & 8.0 \\
Pulping liquors & $739(700)$ & 40.1 \\
\hline
\end{tabular}

Source: Ref. 3 .

The majority of the steam is generated at 4.1 to $8.2 \mathrm{MPa}$ (600 to 1200 psig), which corresponds to about 254 to $299^{\circ} \mathrm{C}\left(490\right.$ to $\left.570^{\circ} \mathrm{F}\right) .^{3}$ The steam is generally used at a much lower temperature, usually not over $204^{\circ} \mathrm{C}\left(400^{\circ} \mathrm{F}\right)$. The high-pressure steam is often expanded through turbines to generate electricity or shaft power.

Fuels for direct heating are predominantly natural gas $\left[85 \times 10^{12} \mathrm{~kJ}\right.$ $\left.\left(81 \times 10^{12} \mathrm{Btu}\right)\right]$ and fuel oil $\left[74 \times 10^{12} \mathrm{~kJ}\left(70 \times 10^{12} \mathrm{Btu}\right)\right] .^{3}$ The only equipment needing high-temperature heat $\left[>816^{\circ} \mathrm{C}\left(1500^{\circ} \mathrm{F}\right)\right]$ is the lime kiln. ${ }^{6}$ Heat to the lime kiln totals $299 \times 10^{12} \mathrm{~kJ}\left(94 \times 10^{12} \mathrm{Btu}\right)$ annually. 6

Electrical consumption in 1975 was $259.0 \times 10^{9} \mathrm{kWhr}, 54 \%$ of which was generated on-site. Potential for the CCC exists in generating the remaining electricity and the steam now being raised in gas-fired boilers. This latter natural gas usage (Table 4.26) amounts to $7.6 \times 10^{9} \mathrm{~m}^{3}(270 \times$ $10^{9} \mathrm{ft}^{3}$ ) annually.

\subsubsection{Stone/clay/glass industries}

The stone/clay/glass and concrete industrial group (SIC 32) consumed $21424 \times 10^{12} \mathrm{~kJ}\left(1350 \times 10^{12} \mathrm{Btu}\right)$ of energy in 1971 . Processes for making glass and cement accounted for $255 \%$ of the total. ${ }^{30}$ These two industries, along with the concrete block and gypsum industries, are discussed in this section. 
Tatle 4.27. Sumary of process heat requirements for major portion of pulp and paper industry $a, b$

\begin{tabular}{|c|c|c|c|c|c|c|c|c|}
\hline \multirow{2}{*}{ Procesś } & \multicolumn{5}{|c|}{ St $\epsilon$ :am requitrement } & \multicolumn{3}{|c|}{$\begin{array}{l}\text { Temperature } \\
{\left[{ }^{\circ} \mathrm{C}\left({ }^{\circ} \mathrm{F}\right)\right]}\end{array}$} \\
\hline & $\begin{array}{l}\text { Per } \\
1.0^{6}\end{array}$ & $\begin{array}{l}\text { ton of indistry preduct } \\
\mathrm{kJ} / \text { metric ton }\left(10^{6} \text { Btu)] }\right.\end{array}$ & $\begin{array}{l}\text { Industry } \\
{\left[10^{12} \mathrm{~kJ}\right.}\end{array}$ & $\begin{array}{l}\text { total } 1975^{c} \\
\left.\left(10^{12} \text { Btu }\right)\right]\end{array}$ & $\begin{array}{c}\text { Pressure } \\
\text { IMPa }(p s: g 1]\end{array}$ & $100-177$ & $(212-350)$ & $>177(>350)$ \\
\hline Kraft pulping & & $3.17(2.73)$ & 109.1 & $(103.4)$ & $0.8 j-1.04(-21)-150)$ & & & $181(358)$ \\
\hline $\begin{array}{l}\text { Kraft black liquor recovery } \\
\text { Evaporation } \\
\text { Air prebeating } d \\
\text { Steam production }\end{array}$ & & $\begin{aligned} 3.33 & (2.82) \\
0.37 & (0.32) \\
11.76 & (10.14)\end{aligned}$ & $\begin{array}{r}114.7 \\
12.8 \\
-405.2\end{array}$ & $\begin{array}{l}(108.7) \\
(12.1) \\
(-384.1)\end{array}$ & $\begin{array}{l}0.28(40) \\
0.28(40) \\
3.14(455 !\end{array}$ & $\begin{array}{l}141 \\
141\end{array}$ & $\begin{array}{l}(287) \\
(287)\end{array}$ & $371(700)$ \\
\hline $\begin{array}{l}\text { Kraft pulp bleaching } \\
\text { Caustic soda extraction } \\
\text { Hypochlorite bleaching } \\
\text { Chlorine dioxide bleachirg } \\
\text { Hypochlorite bleaching }\end{array}$ & & $\begin{array}{l}1.80(1.5 \vdots) \\
0.66(0.5 \%) \\
2.46(2.1 \%) \\
0.63(0.5 \vdots)\end{array}$ & $\begin{array}{l}61.9 \\
22.8 \\
84.7 \\
21.6\end{array}$ & $\begin{array}{l}(58.7) \\
(21.6) \\
(80.3) \\
(20.5)\end{array}$ & $\begin{array}{l}0.28(40) \\
0.28(40) \\
0.28(40) \\
0.28(40)\end{array}$ & $\begin{array}{l}141 \\
141 \\
141 \\
141\end{array}$ & $\begin{array}{l}(287) \\
(287) \\
(287) \\
(287)\end{array}$ & \\
\hline $\begin{array}{l}\mathrm{NSSC}^{f} \text { pulping } \\
\mathrm{NSSC}^{f} \text { black liquor rec very }\end{array}$ & & $0.17(0.1 \vdots)$ & 6.0 & $(5.7)$ & $1.04(150 !$ & & & $184(364)$ \\
\hline $\begin{array}{l}\text { Evaporation } \\
\text { Air preheating } d \\
\text { Steam production }\end{array}$ & & $\begin{array}{l}0.13(0.11) \\
0.01(0.01) \\
0.44(0.3 \%)\end{array}$ & $\begin{array}{r}4.4 \\
0.4 \\
-15.2\end{array}$ & $\begin{array}{l}(4.2) \\
(0.4) \\
(-14.4)\end{array}$ & $\begin{array}{l}0.28(40) \\
0.28(40) \\
3.14(455\end{array}$ & $\begin{array}{l}141 \\
141\end{array}$ & $\begin{array}{l}(287) \\
(287 !\end{array}$ & $371(700)$ \\
\hline Groundwood Jleaching & & $0.05(0.0 \div)$ & 1.6 & $(1.5)$ & $0.28(40)$ & 141 & $(287 !$ & \\
\hline Pulp drying & & $0.34(0.2 \vdots)$ & 11.6 & $(11.0)$ & $0.2 \varepsilon-1.04 \quad(40-150)$ & 177 & (350) & \\
\hline Papermaking & & $8.29(7.1 \equiv)$ & 377.7 & $(358.0)^{g}$ & $0.2 \varepsilon-1.04(40-150)$ & 177 & $(350)$ & \\
\hline Total prccess & reat & & 829.3 & $(786.1)$ & & & & \\
\hline Net after by-product $c$ & $\in$ dit & & 408.9 & $(387.6)$ & & & & \\
\hline
\end{tabular}

$a_{\text {Accounts }}$ for $91 \%$ of virgin fulp production, $71 \%$ of total paper production.

Onits lime kilns.

${ }^{C}$ Calculated from $19 j 3$ production data (Table 4.25) for pulp processes studied, multiplie. by 0.86 , the ratio of pulp production 1973/1975.

$d_{\text {By-product credit. }}$

$e_{\text {In }}$ five-step bleacing.

$f_{\text {NSSC }}=$ Neutral sulfite semichemical.

${ }^{g}$ Calculated from th $\equiv 50 \times 10^{6}$ tor:s paper and paper board production estimate for 1975.

Source: Ref. 6. 
4.3.5.1 Portland cement. The Portland cement industry consists of 166 plants in 41 states and Puerto Rico. ${ }^{6}$ Two basic processes exist for cement production: wet and dry. The only difference is that the wet process utilizes a slurry to feed the raw materials into the kiln or preheater, whereas the dry process feeds dry materials. This process is generally more efficient and has recently been receiving. greater attention. ${ }^{6}$ Energy consumption and costs are critical in cement manufacturing (about $40 \%$ of production cost); few wet processes have been installed in the recent past, and many wet processes have been converted to dry. A flowsheet for cement production is shown in Fig. 4.23 (Ref. 6).

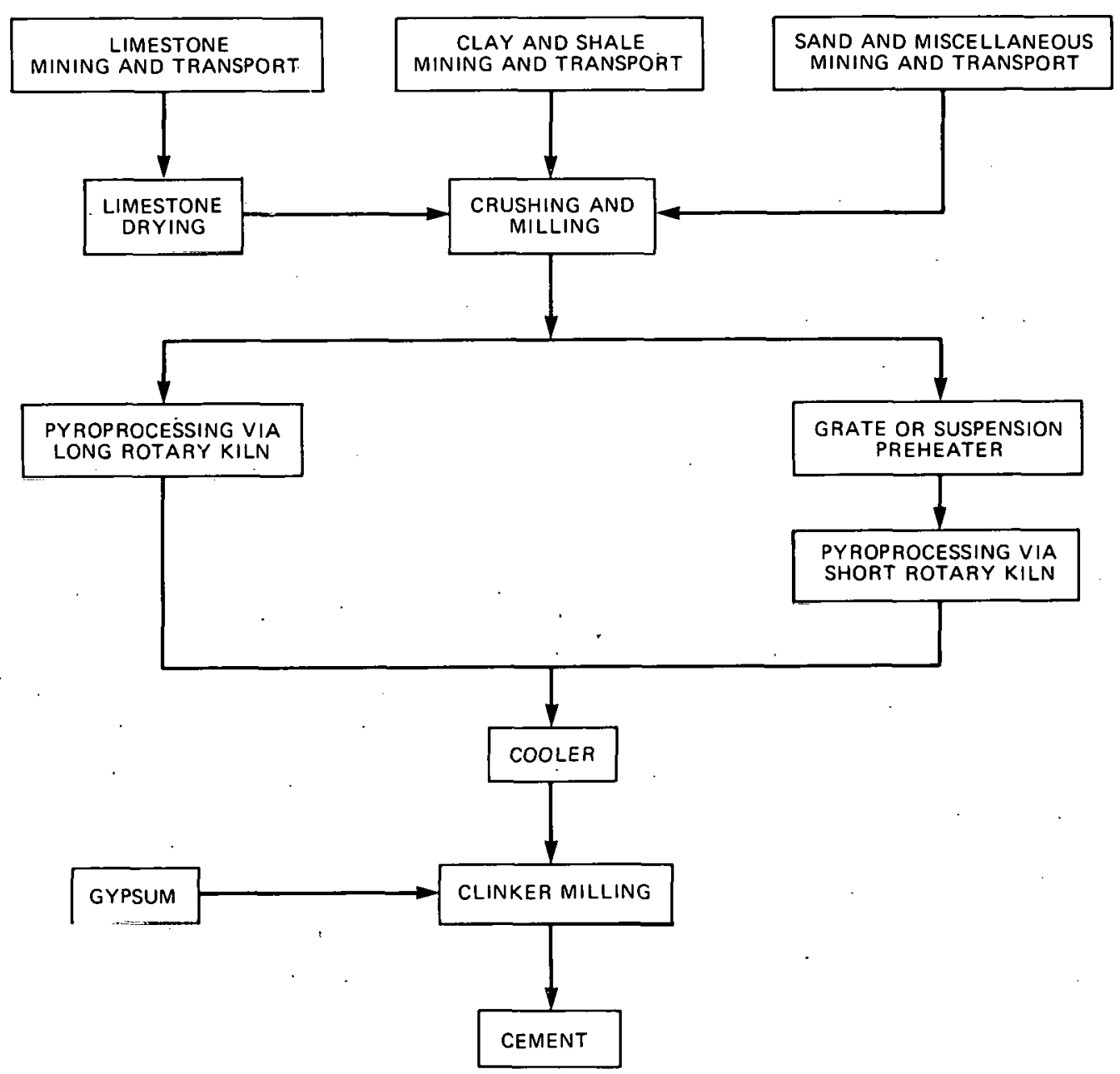

Fig. 4.23. Flow sheet for cement manufacturc. 
The kiln is by far the largest energy consumer, accounting for a1most $80 \%$ of the total. Essentially all fossil fuels used by the industry are consumed in the kiln. Process energy demands are supplied in Table 4. 28.

Although the process temperatures are too high for direct use of the CCC thermal energy, electricity costs may make the internal generation attractive. Dry process plants generate $220 \%$ of their own power. ${ }^{31}$ Furthermore, as reported in Ref. 6, the Portland Cement Association estimates that by 1980 more than $90 \%$ of the industry capacity will be able to utilize coal. ${ }^{32}$ Concentration of the industry in New York, Ohio, and Pennsylvania, where gas curtailments have been experienced, is certainly influential in this trend toward coal.

4.3.5.2 Concrete block and brick industry. Approximately $48 \times 10^{6}$ metric tons $\left(53 \times 10^{6}\right.$ tons $)$ of block and brick are manufactured annually. The industry consumed about $16.2 \times 10^{12} \mathrm{~kJ}\left(15.5 \times 10^{12} \mathrm{Btu}\right)$ in 1971 , $92 \%$ of which was used for process heat. ${ }^{5}$ Two basic processes, highpressure (autoclave) and low-pressure, are utilized in the production. Autoclave systems require twice the energy but have faster processing times; however, the recent trend is toward the low-pressure plants.

The flow sheet for concrete block manufacture is presented in Fig. 4.24, and a summary of the process heat requirements is given in Table 4.29. Electricity consumption is on the order of $10^{9} \mathrm{kWhr}$ annually. Interest has been expressed in the CCC by a local firm because of its potential for electric production only. However, the temperature requirements indicate that at least some of the process heat can be supplied. Fuels used for the process heat are split between gas and oil at 71 and $29 \%$, respectively. The potential gas displacement by coal in the industry would be $00.28 \times 10^{9} \mathrm{~m}^{3}\left(10 \times 10^{9} \mathrm{ft}^{3}\right)$ annually, and o11 displacement could be as high as $0.11 \times 10^{6} \mathrm{~m}^{3}\left(0.7 \times 10^{6} \mathrm{bbl}\right)$. Present use of coal is very small.

4.3.5.3 Gypsum. The gypsum industry is characterized by a highly competitive market and simple processing, with primary products of gypsum board and plaster materials.

Process heat requirements totalled $\sim 48.4 \times 10^{12} \mathrm{~kJ}\left(45.9 \times 10^{12} \mathrm{Btu}\right)$ in 1973 . About $70 \%$ of the heat is in the form of steam at 177 to $343^{\circ} \mathrm{C}$ 
Table 4.28. Energy in cement production via long rotary kiln $-1973^{a}$

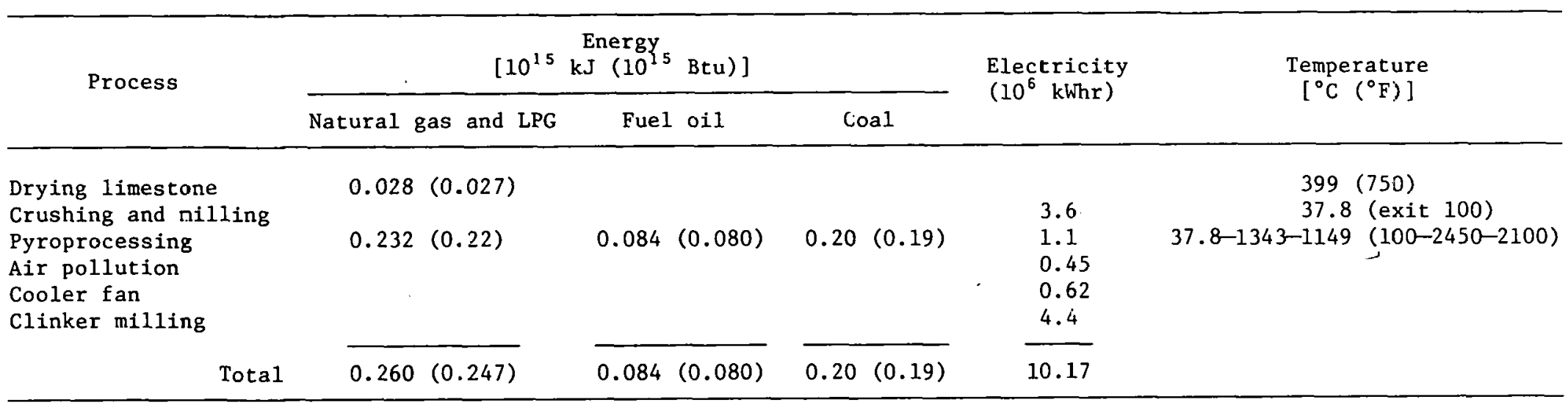

$a_{1973}$ U.s. production $-76 \times 10^{6}$ metric tons $\left(84.1 \times 10^{6}\right.$ tons). Use of this type kiln was not exclusive in practice. Actual 1973 process heat was about $515 \times 10^{12} \mathrm{~kJ}\left(490 \times 10^{12} \mathrm{Btu}\right)$.

Source: Ref. 6 . 
- Table 4.29. Summary of 1971 process teat requirements in the concrete block-and trick industry by process

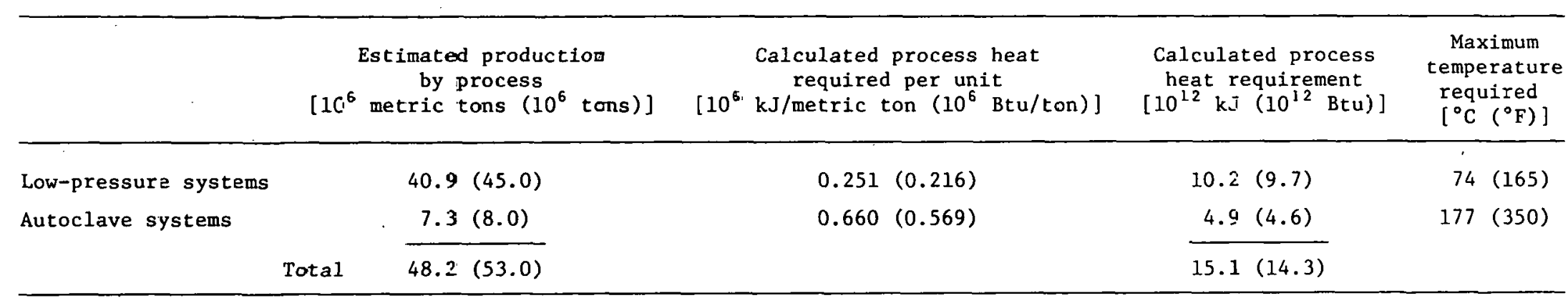

Source: Ref. 6. 


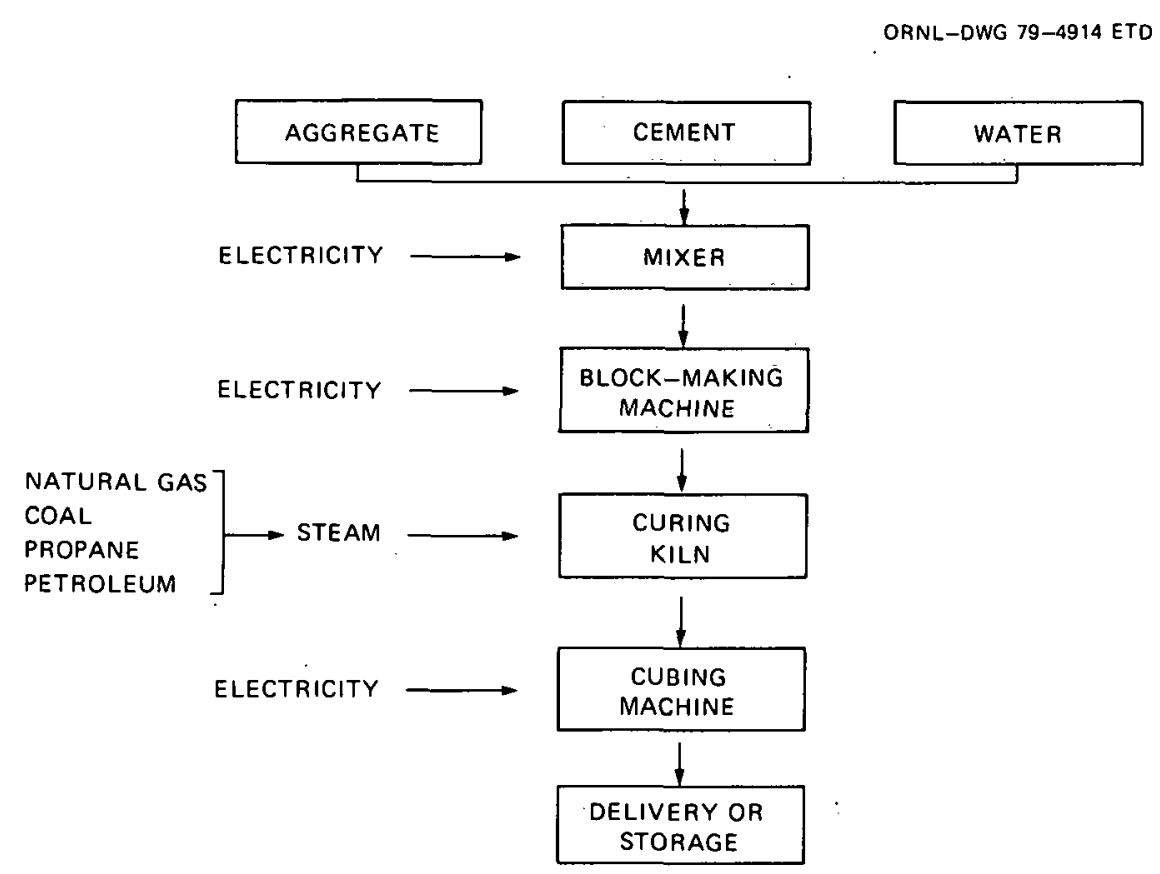

Fig. 4.24. Flow sheet for concrete block and brick manufacture (Ref. 6).

$\left(350\right.$ to $650^{\circ} \mathrm{F}$ ), with the remaining being direct heat at $177^{\circ} \mathrm{C}\left(350^{\circ} \mathrm{F}\right)$ or less. The basic production sequence is illustrated in Fig. 4.25 (Ref. 6). Process heat and electrical requirements are provided in Tables 4.30 and 4.31. The heavy dependence on natural gas and process temperature involved indicates that the industry is a potential target for the CCC. Possible product contamination is apparently preventing to some extent the conversion to coal. There is, however, some incentive in the $0.85 \times$ $10^{9} \mathrm{~m}^{3}\left(30 \times 10^{9} \mathrm{ft}^{3}\right)$ of natural gas to be displaced annually.

4.3.5.4 Glass industry. The glass industry is characterized by demands for very high-temperature heat. From 60 to $85 \%$ of the energy is needed at over $1093^{\circ} \mathrm{C}\left(2000^{\circ} \mathrm{F}\right)$.

A typical flow sheet for production of glass containers is shown in Fig. 4.26, where the temperatures are noted. The production sequence for flat glass is similar. Glass container production involves the largest tonnage of glass in the industry. Figures for annual production vary from 8.0 to $8.4 \times 10^{9} \mathrm{~kg}\left(17.7\right.$ to $\left.18.5 \times 10^{9} \mathrm{lb}\right)$ in $1967 .{ }^{33}$ 
Table 4.30. Energg use in gypsum canifacture, $10^{6} \mathrm{~kJ}$ per metric ton (10 ${ }^{6}$ Btu per ton) processed (1973)

\begin{tabular}{|c|c|c|c|c|c|c|c|c|}
\hline & $\begin{array}{c}\text { Natural } \\
\text { gas }\end{array}$ & LPG & $\begin{array}{l}\text { Other } \\
\text { petrole } 1 \mathrm{~m} \\
\text { products }\end{array}$ & Coai & Electricity ${ }^{a}$ & Total & Percent & $\begin{array}{c}\text { Maximum } \\
\text { temperature } \\
{\left[{ }^{\circ} \mathrm{C}\left({ }^{\circ} \mathrm{F}\right)\right]}\end{array}$ \\
\hline $\begin{array}{l}\text { Mining or cuarrying } \\
\text { Crushing } \\
\text { Grinding and drying } \\
\text { Calcining } \\
\text { Finish processing }\end{array}$ & $\begin{array}{l}0.12(0.1) \\
0.78(0.67) \\
2.34(2.02)\end{array}$ & $\begin{array}{r}0(>0.0) \\
0(>0.0) \\
0.01 \quad(0.01)\end{array}$ & $\begin{array}{ll}0.29 & (0.25) \\
0 .(11 & (0.31) \\
0.08 & (0.37) \\
0.23 & (0.20)\end{array}$ & $\begin{array}{ll}0.01 & (0.01) \\
0.04 & (0.03) \\
0.09 & (0.08)\end{array}$ & $\begin{array}{l}0.02(0.02) \\
0.01 \\
0.04(0.01) \\
0.04(0.03) \\
0.17(0.03) \\
(0.15)\end{array}$ & $\begin{array}{ll}0.31 & (0.27) \\
0.11 & (0.01) \\
0.17 & (0.15) \\
0.73 & (0.80) \\
2.35 & (2.46)\end{array}$ & $\begin{array}{r}7.3 \\
0.3 \\
4.1 \\
21.7 \\
65.6\end{array}$ & $\begin{array}{l}\text { Ambient } \\
\text { Ambient } \\
\text { Nominal } \\
160(320) \\
299(570)\end{array}$ \\
\hline TotaI & $3.24 \quad(2.73)$ & $0.012(0.02)$ & $0.61(0.53)$ & $0.14(0.12)$ & $0.28 \quad(0.24)$ & $4.28 \quad(3.69)$ & 100.0 & \\
\hline
\end{tabular}

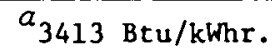

Source: Ref. 6. 


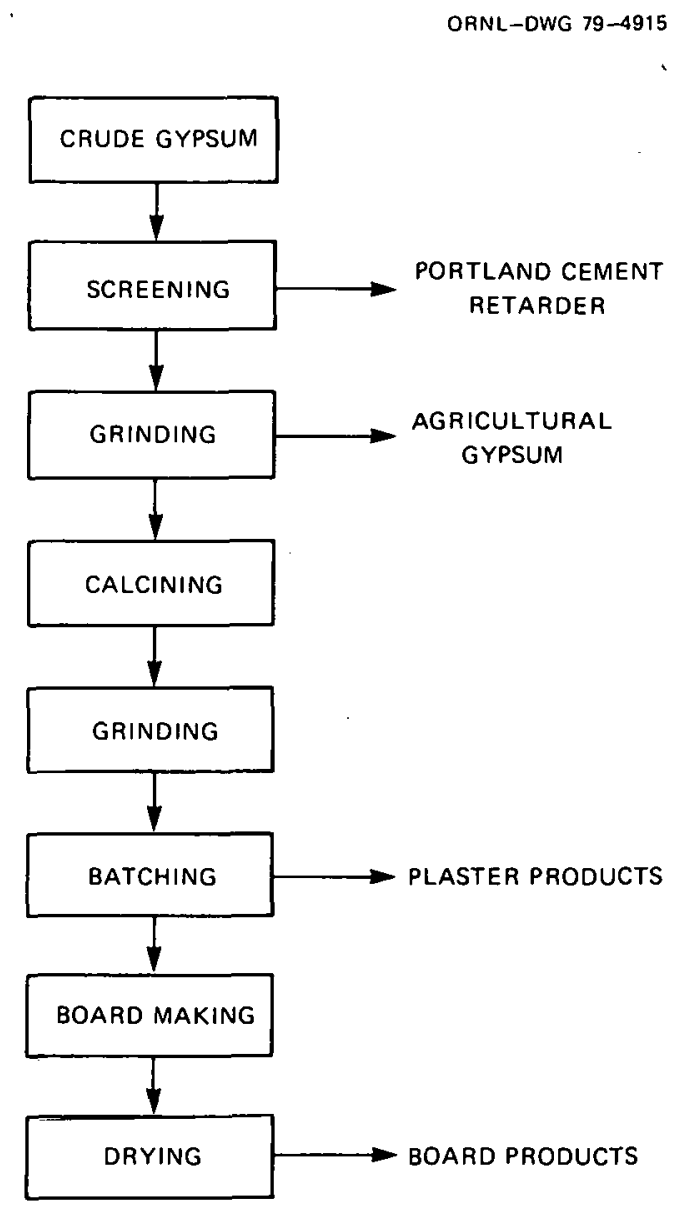

Fig. 4.25. Flow sheet for gypsum production (Ref. 6).

Table 4.31. Process heat required for U.S. 1973 gypsum production

\begin{tabular}{|c|c|c|c|}
\hline Process/operation & $\begin{array}{c}{ }^{\text {Gypsum }}{ }^{a} \\
{\left[10^{6} \mathrm{~kJ} / \text { metric ton }\right.} \\
\left.\left(10^{6} \mathrm{Btu} / \mathrm{ton}\right)\right]\end{array}$ & $\begin{array}{l}\text { fypsinm produced } \\
{\left[10^{6} \text { metric tons }\right.} \\
\left.\left(10^{6} \text { tons }\right)\right]\end{array}$ & $\begin{array}{l}\text { Total process heat } \\
{\left[10^{12} \mathrm{~kJ}\left(10^{12} \mathrm{Btu}\right)\right]}\end{array}$ \\
\hline $\begin{array}{l}\text { Drying } \\
\text { Calcining } \\
\text { Finish processing }\end{array}$ & $\begin{array}{l}0.14(0.12) \\
0.89(0.77) \\
2.68(2.31)\end{array}$ & $\begin{array}{l}18.73(20.635)^{b} \\
13.54(14.916)^{c} \\
12.52(13.793)^{d}\end{array}$ & $\begin{aligned} 2.6 & (2.5) \\
12.1 & (11.5) \\
33.7 & (31.9)\end{aligned}$ \\
\hline Total & & & $48.4(45.9)$ \\
\hline
\end{tabular}

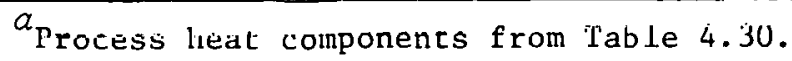

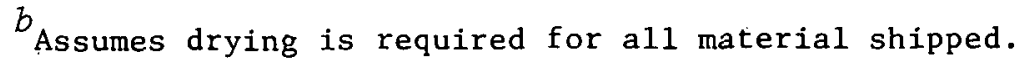

${ }^{c}$ Includes plasters and prefabricated products.

$d_{\text {Excludes plasters. }}$

Source: Ref, 6 . 


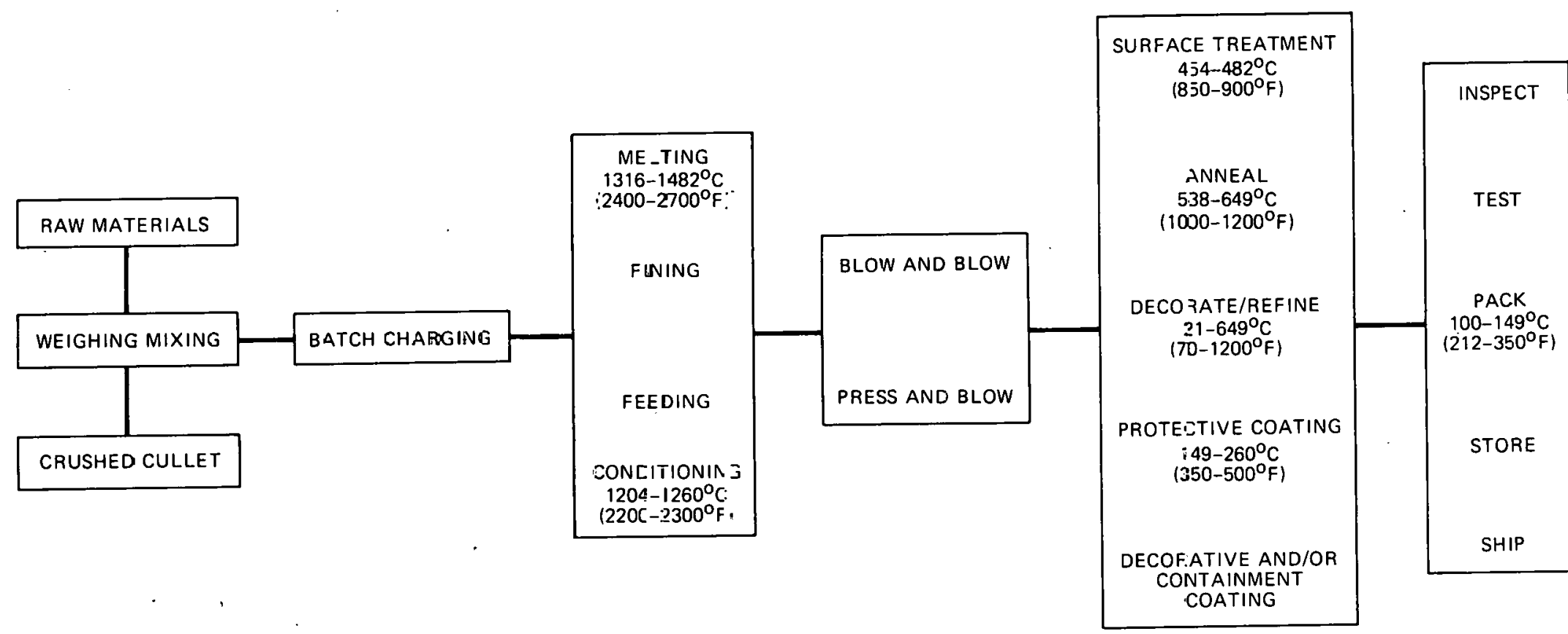

Fig. 4.26. Process f-ow diagran: SIC 3221, glass containers (Ref.6). 
Process heat and temperature data are provided in Table 4.32, and the fuels and electricity used in glass container production are listed in Table 4.33 .

Table 4.32. Process heat in glass industry (1975)

\begin{tabular}{rc}
\hline $\begin{array}{c}\text { Temperature band } \\
{\left[{ }^{\circ} \mathrm{C}\left({ }^{\circ} \mathrm{F}\right)\right]}\end{array}$ & $\begin{array}{l}\text { Quantity } \\
{\left[10^{12} \mathrm{~kJ}\left(10^{12} \mathrm{Btu}\right)\right]}\end{array}$ \\
\hline$<177(<350)$ & $22(21)$ \\
$177-593(350-1100)$ & $19(18)$ \\
$593-816(1100-1500)$ & $1.1 .4(10.8)$ \\
$>816(>1500)$ & $304(288)$ \\
\hline
\end{tabular}

Source: Ref. 6.

The widespread implementation of the CCC would probably occur only if the trend continues toward electric glass melting, which is an established procedure. Possible product contamination concerning the use of coal is also a factor in the glass industry. Economical in-house electric generation is always a possible incentive, along with preheating, which would reduce the demand on natural gas. The present annual displacement potential, based on the process heat required at less than $816^{\circ} \mathrm{C}\left(1500^{\circ} \mathrm{F}\right)$, is about $1.6 \times 10^{9} \mathrm{~m}^{3}\left(57 \times 10^{9} \mathrm{ft}^{3}\right)$ of natural gas, which is nor negliglble by any standard.

\subsubsection{Food industry}

Energy consumption in the food industry is rather difficult to quantify because of (1) the diversity of the industry and (2) incomplete information (probably resulting from the minor importance of energy costs in many food processes). In 1971, the approximate total energy consumption for the food category (SIC 20) was about $945 \times 10^{12} \mathrm{~kJ}$ $\left(900 \times 10^{12} \mathrm{Btu}\right)^{30}$ (3413 Btu/kWhr electric1ty).

The generation of process steam is by far the most important use of fossil fuels. Electricity is required for mechanical drives and 
Table 4.33. Energy sources for glass contaizer production

\begin{tabular}{|c|c|c|c|}
\hline Energy source & 1967 consumption & Consumption per ton of container & $\begin{array}{c}10^{6} \mathrm{~kJ} \text { per metric ton } \\
\left(10^{6} \text { Btu per ton }\right)\end{array}$ \\
\hline \multicolumn{4}{|l|}{ Coal } \\
\hline Refined oils & $241 \mathrm{~m}^{3}(1515 \mathrm{bbl})$ & $0.03 \mathrm{~m}^{3}(7.18 \mathrm{gal})$ & $1.230(1.060)$ \\
\hline Naturai gas & $2.7 \times 10^{9} \mathrm{~m}^{3}\left(94.6 \times 10^{9} \mathrm{ft}^{3}\right)$ & $0.3 \times 10^{3} \mathrm{~m}^{3}\left(10.67 \times 10^{3} \mathrm{ft}^{3}\right)$ & $12.81(11.046)$ \\
\hline $\begin{array}{l}\text { Electric energy } \\
\text { (purchased) }\end{array}$ & $2.33 \times 10^{3} \mathrm{k} / \mathrm{hr}$ & $263 \mathrm{kWhr}$ & $1.041(0.897)^{a}$ \\
\hline
\end{tabular}

$a_{3413 \mathrm{Btu} / \mathrm{kWhr} \text {. }}$

Source: Ref. 33. 
refrigeration. The heat energy and electricity consumptions for 13 food industries are listed in Table 4.34. Natural gas accounted for $268 \%$ of the fuels consumed for heat or internal power generation, with fuel oils and coal constituting $\sim 18$ and $14 \%$, respectively.

Table 4.34. Heat and electricity consumption by 13 food processing industries during $1971^{a}$

\begin{tabular}{|c|c|c|c|c|}
\hline \multirow{2}{*}{ Process } & \multicolumn{2}{|c|}{$\left[10^{15}\right.$ kJ Heat $\left.^{b}\left(10^{15} \mathrm{Btu}\right)\right]$} & \multicolumn{2}{|c|}{$\left[10^{15} \mathrm{~kJ}\left(10^{15} \mathrm{Btu}\right)\right]$} \\
\hline & Census $^{c}$ & Ref. 34 & Census & Ref. 34 \\
\hline Meat packing & $0.083(0.079)$ & $0.081(0.077)$ & $0.032(0.030)$ & $0.036(0.034)$ \\
\hline Beet sugar & $0.088(0.083)$ & $0.078(0.074)$ & $0.0004(0.0004)$ & $0.001(0.001)$ \\
\hline Cane sugar & $0.036(0.034)$ & $0.046(0.044)$ & $0.0002(0.0002)$ & $0.0003(0.0003)$ \\
\hline Wet corn milling & $0.064(0.061)$ & $0.065(0.062)$ & $0.009(0.009)$ & $0.011(0.010)$ \\
\hline Fluid milk & $0.046(0.044)$ & $0.046(0.044)$ & $0.039(0.037)$ & $0.039(0.037)$ \\
\hline Prepared animal feeds & $0.049(0.046)$ & $0.056(0.053)$ & $0.028(0.027)$ & $0.033(0.031)$ \\
\hline $\begin{array}{l}\text { Frozen fruits and } \\
\text { vegetables }\end{array}$ & $0.027(0.026)$ & $0.028(0.027)$ & $0.027(0.026)$ & $0.028(0.027)$ \\
\hline $\begin{array}{l}\text { Canned fruits and } \\
\text { vegetables }\end{array}$ & $0.052(0.049)$ & $0.044(0.042)$ & $0.011(0.010)$ & $0.008(0.008)$ \\
\hline $\begin{array}{l}\text { Sausage and meat } \\
\text { processing }\end{array}$ & $0.018(0.017)$ & $0.018(0.017)$ & $0.009(0.009)$ & $0.012(0.011)$ \\
\hline Malt beverages & $0.045(0.043)$ & $0.045(0.043)$ & $0.020(0.021)$ & $0.027(0.026)$ \\
\hline $\begin{array}{l}\text { Animal and marine } \\
\text { fats and oils }\end{array}$ & $0.036(0.034)$ & $0.023(0.022)$ & $0.005(0.005)$ & $0.004(0.004)$ \\
\hline $\begin{array}{l}\text { Bread, cake, and } \\
\text { related products }\end{array}$ & $0.046(0.044)$ & $0.052(0.049)$ & $0.026(0.025)$ & $0.021(0.020)$ \\
\hline Soybean oil & $0.040(0.038)$ & $0.041(0.039)$ & $0.017(0.016)$ & $0.017(0.016)$ \\
\hline
\end{tabular}

In general, the process steam is required at low temperatures, $<204^{\circ} \mathrm{C}\left(400^{\circ} \mathrm{F}\right)$. A few operations presently utilize a direct gas flame, but this is not absolutely necessary.

Data on temperature and heat requirements for several of the industries presented in Ref. 6 are included in this report. 
4.3.6.1 Pork processing. The flow sheet for pork processing is shown in Fig. 4.27. Process energy required is shown in Table 4.35.

The gas flame can be replaced by hot air for polishing and singeing. According to Ref. 5, $260^{\circ} \mathrm{C}\left(500^{\circ} \mathrm{F}\right)$ is sufficient. Thus the CCC is capable of supplying all heat and electricity. The heat values shown are generated entirely by gas; therefore, the displacement potential for pork processing could be as high as $0.82 \times 10^{9} \mathrm{~m}^{3}\left(29 \times 10^{9} \mathrm{ft}^{3}\right)$ of natural gas annually.

4.3.6.2 Meat processing. Conversion of raw pork into final meat products is often done in an integrated plant with the slaughtering and basic processing. The general production sequence is shown in Fig. 4.28. Process energy data are given in Table 4.36 .

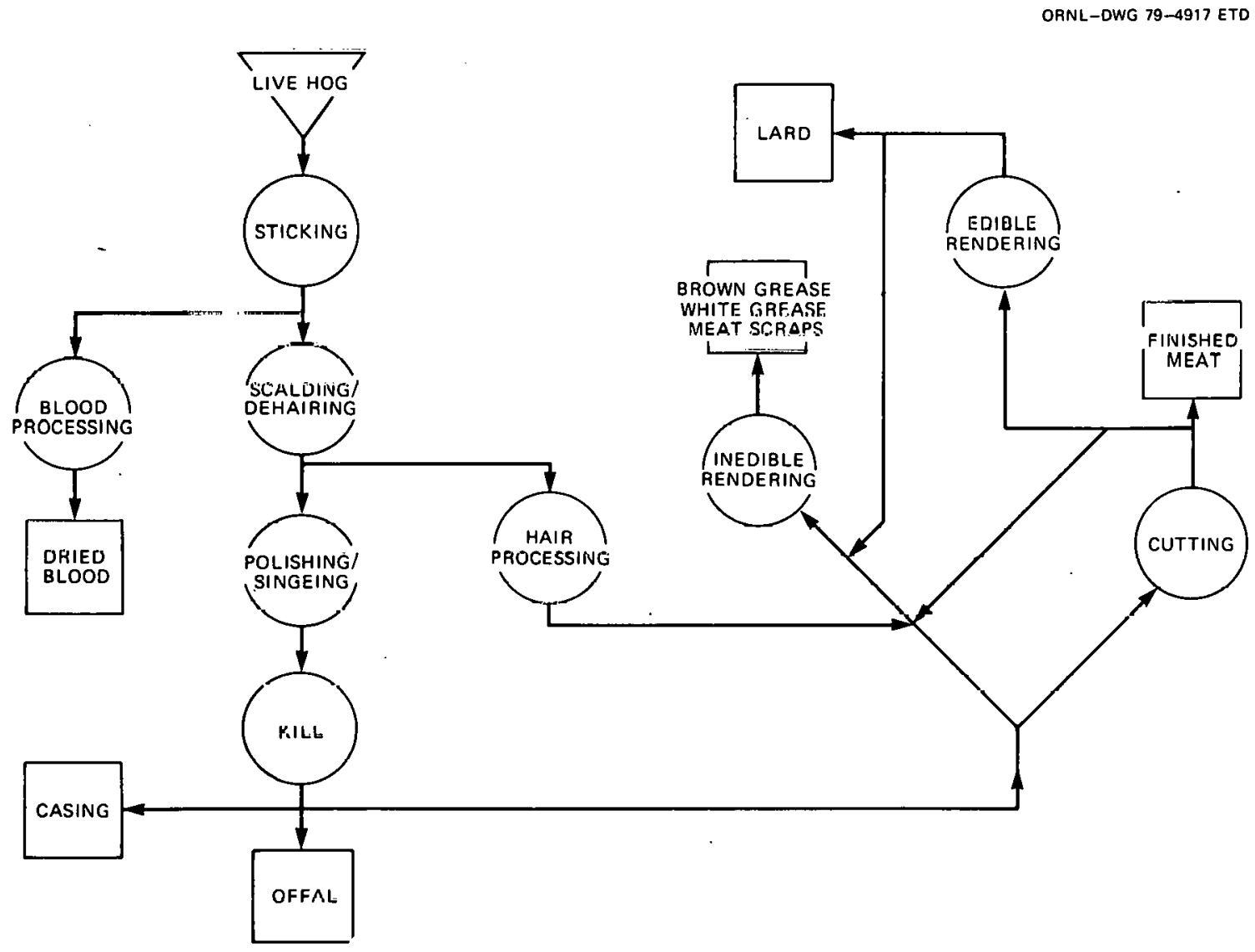

Fig. 4.27. Process flow sheet for hog slaughtering and processing (SIC 2011) (Ref. 6). 
Table 4.35. Process energy (fuel used) in pork processing

\begin{tabular}{|c|c|c|c|}
\hline Operation & {$\left[\mathrm{kJ} / \mathrm{kg}(\mathrm{Btu} / \mathrm{lb})^{a}\right]$} & $\begin{array}{c}\text { Temperature } \\
{\left[{ }^{\circ} \mathrm{C}\left({ }^{\circ} \mathrm{F}\right)\right]}\end{array}$ & $\begin{array}{c}\text { Electricity } \\
{[\mathrm{kJ} / \mathrm{kg}(\text { Btu } / \mathrm{lb})}\end{array}$ \\
\hline $\begin{array}{l}\text { Livestock } \\
\text { Sticking } \\
\text { Blood processing } \\
\text { Scalding/dehair } \\
\text { Hair processing } \\
\text { Polishing/singeing } \\
\text { Killing } \\
\text { Cooling (refrigeration) } \\
\text { Edible rendering } \\
\text { Inedible rendering } \\
\text { Motive power } \\
\text { Lighting } \\
\text { Sterilization }\end{array}$ & $\begin{aligned} 56.1 & (24.1) \\
149.6 & (64.3) \\
24.4 & (10.5) \\
140.5 & (60.4)^{c} \\
& \\
993.4 & (427.1)^{d} \\
60.2 & (25.9) \\
516.4 & (222.0) \\
1195.6 & (514.0)\end{aligned}$ & $\begin{array}{c}188(370) \\
146(295) \\
146(295) \\
\text { Flame } \\
143(290) \\
188(370)\end{array}$ & $\begin{aligned} 1.2 .6 & (5.4) \\
6.0 & (2.6) \\
26.1 & (11.2) \\
0.2 & (0.1) \\
10.7 & (4.6) \\
17.9 & (7.7) \\
4.7 & (2.0) \\
25.1 & (10.8) \\
94.0 & (40.4) \\
31.2 & (13.4) \\
68.4 & (29.4)\end{aligned}$ \\
\hline Total & $3136.2(1348.0)$ & & $296.9(128.0)$ \\
\hline $\begin{array}{l}a_{\text {Per } \mathrm{kg} \text { or lb of } 1 \mathrm{i}} \\
\left(22.3 \times 10^{9} \mathrm{lb}\right) . \\
b_{3413 \mathrm{Btu} / \mathrm{kWhr} .} \\
{ }^{c_{\text {Nonsteam. }}} \\
d_{\text {Nonsteam; natural }} \\
\text { Source: Ref. } 6 .\end{array}$ & and propane us & 75 total was & $10 \times 10^{9} \mathrm{~kg}$ \\
\hline
\end{tabular}

Table 4.36. Process energy (fuels used) in meat processing

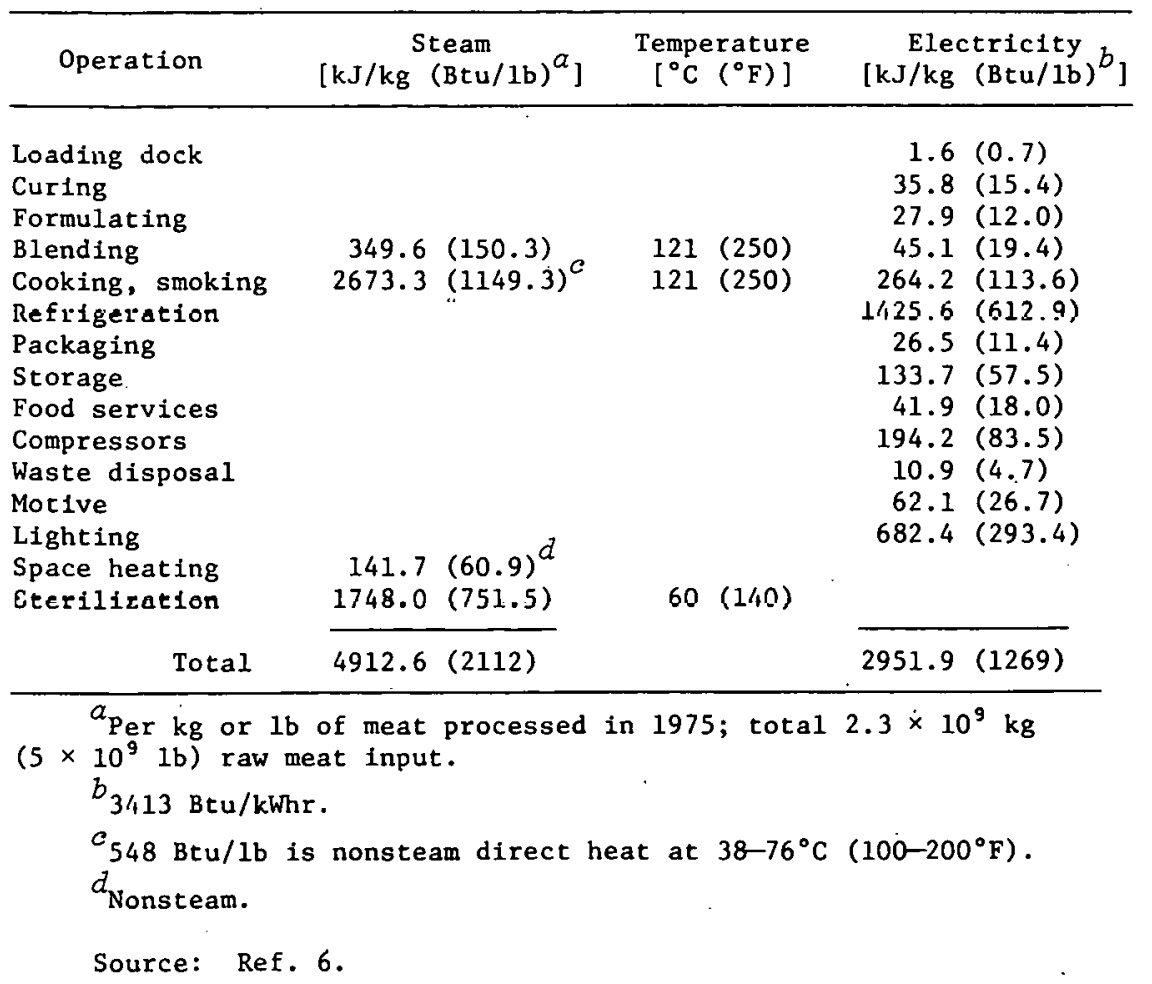


ORNL-DWG 79-4918 ETD

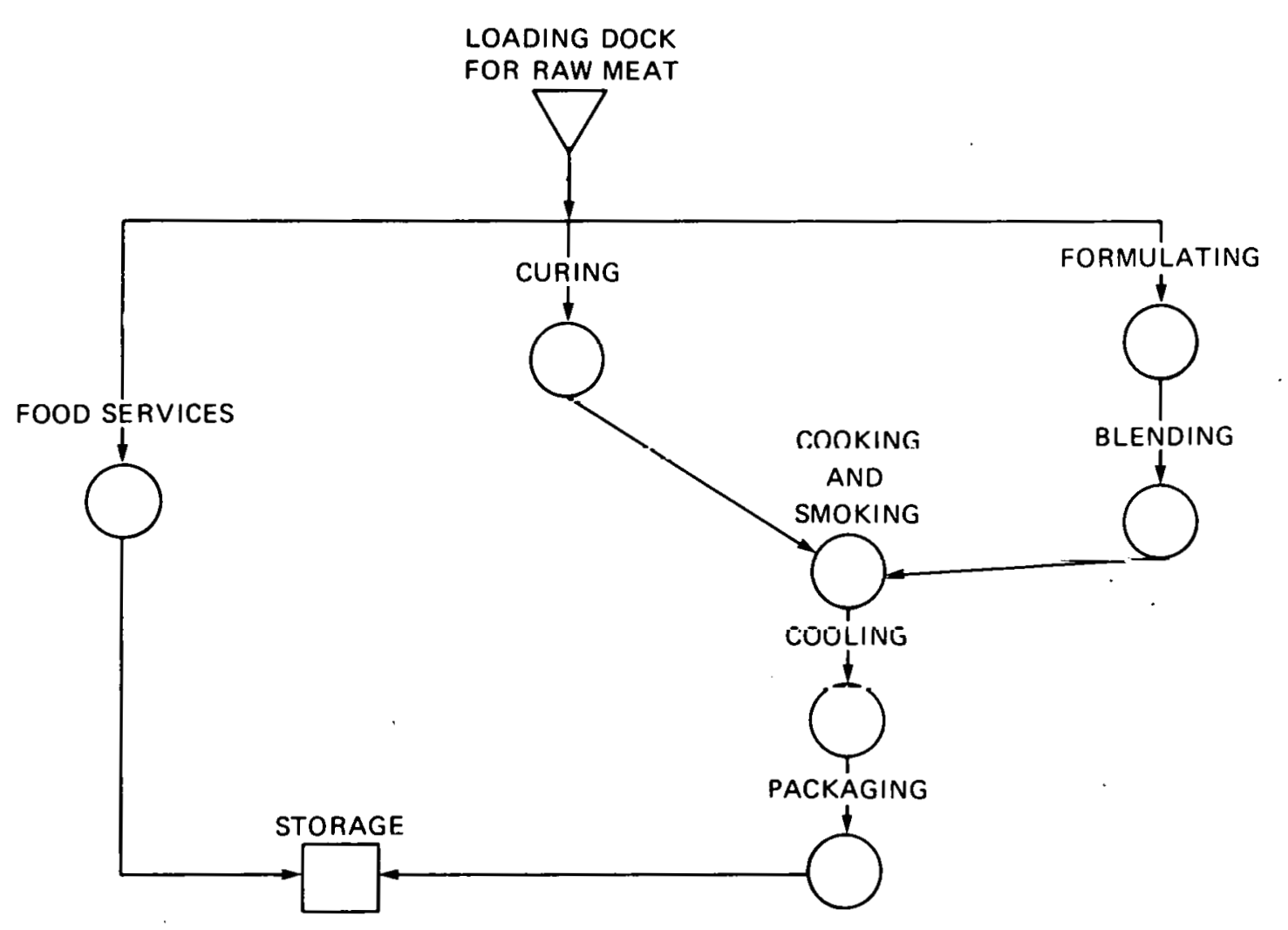

Fig. 4.28. Process flow sheet for meat processing (SIC 2013) (Ref.6).

The fuels used were $19 \%$ fuel oil and $81 \%$ natural gas. The electrical power consumption is substantial, giving a heat/power ratio of about 1.7. This nonintegrated plant is, therefore, a borderline case for the CCC if total electricity demand is to be satisfied. However, the integrated plant could be an ideal application. Substitution of coal for natural gas for process heat in this industry would annually displace $w 0.23 \times 10^{y} \mathrm{~m}^{8}\left(8 \times 10^{y} \mathrm{ft}^{3}\right)$ of gas.

4.3.6.3 Soybean meal processing. Production of soybean meal, flour, and oil are grouped into SIC 2075. The flow diagram for a typical plant is illuslrated in Fig. 4.29 (Ref. 6). Trocess energy requirements are summarized in Table 4.37.

The energy source is essentially $100 \%$ natural gas for the in-house direct heat, which is $0.17 \times 10^{9} \mathrm{~m}^{3}\left(6 \times 10^{9} \mathrm{ft}^{3}\right)$ in 1975 . 
Table 4.37. Process energy (fuels) used in soybean processing

\begin{tabular}{|c|c|c|c|}
\hline Operation & $\frac{\text { Steam }}{\left[\mathrm{kJ} / \mathrm{kg}(\mathrm{Btu} / \mathrm{lb})^{a}\right]}$ & $\begin{array}{c}\text { Temperature } \\
{\left[{ }^{\circ} \mathrm{C}\left({ }^{\circ} \mathrm{F}\right)\right]}\end{array}$ & $\begin{array}{c}\text { Electricity } \\
{\left[\mathrm{kJ} / \mathrm{kg}(\mathrm{Btu} / 1 \mathrm{~b}){ }^{2}\right]}\end{array}$ \\
\hline $\begin{array}{l}\text { Storage and cleaning } \\
\text { Dryer } \\
\text { Storage } \\
\text { Cleaning, weighing, cracking } \\
\text { Dehuller } \\
\text { Conditioner' } \\
\text { Flaker } \\
\text { Extractor } \\
\text { Desolventizer } \\
\text { Toaster } \\
\text { Flasi desolventizer } \\
\text { Flasi chamber }\end{array}$ & $\begin{array}{r}246.3(105.9)^{c} \\
148.9(64)^{d} \\
79.8(34.3)^{d}\end{array}$ & $\begin{aligned} 232 & (450) \\
232 & (450) \\
232 & (450) \\
121-127 & (250-260)\end{aligned}$ & $\begin{aligned} 39.3 & (16.9) \\
8.6 & (3.7) \\
2.6 & (1.1) \\
30.2 & (13.0) \\
32.1 & (13.8) \\
3.3 & (1.4) \\
47.9 & (20.6) \\
8.8 & (3.8) \\
14.2 & (6.1) \\
77.7 & (33.4) \\
15.6 & (6.7) \\
10.0 & (4.3)\end{aligned}$ \\
\hline Total & $1456.2(626.1)$ & & $290.3(124.8)$ \\
\hline
\end{tabular}

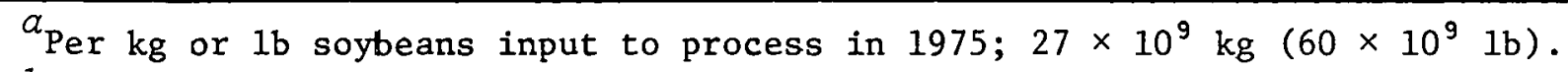

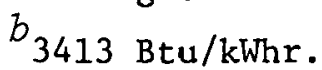

$c_{\text {Nonsteam. }}$

$d_{\text {Purchased steam from utility. }}$

Source: Ref. 6 . 
ORNL-DWG 79-4919ETO

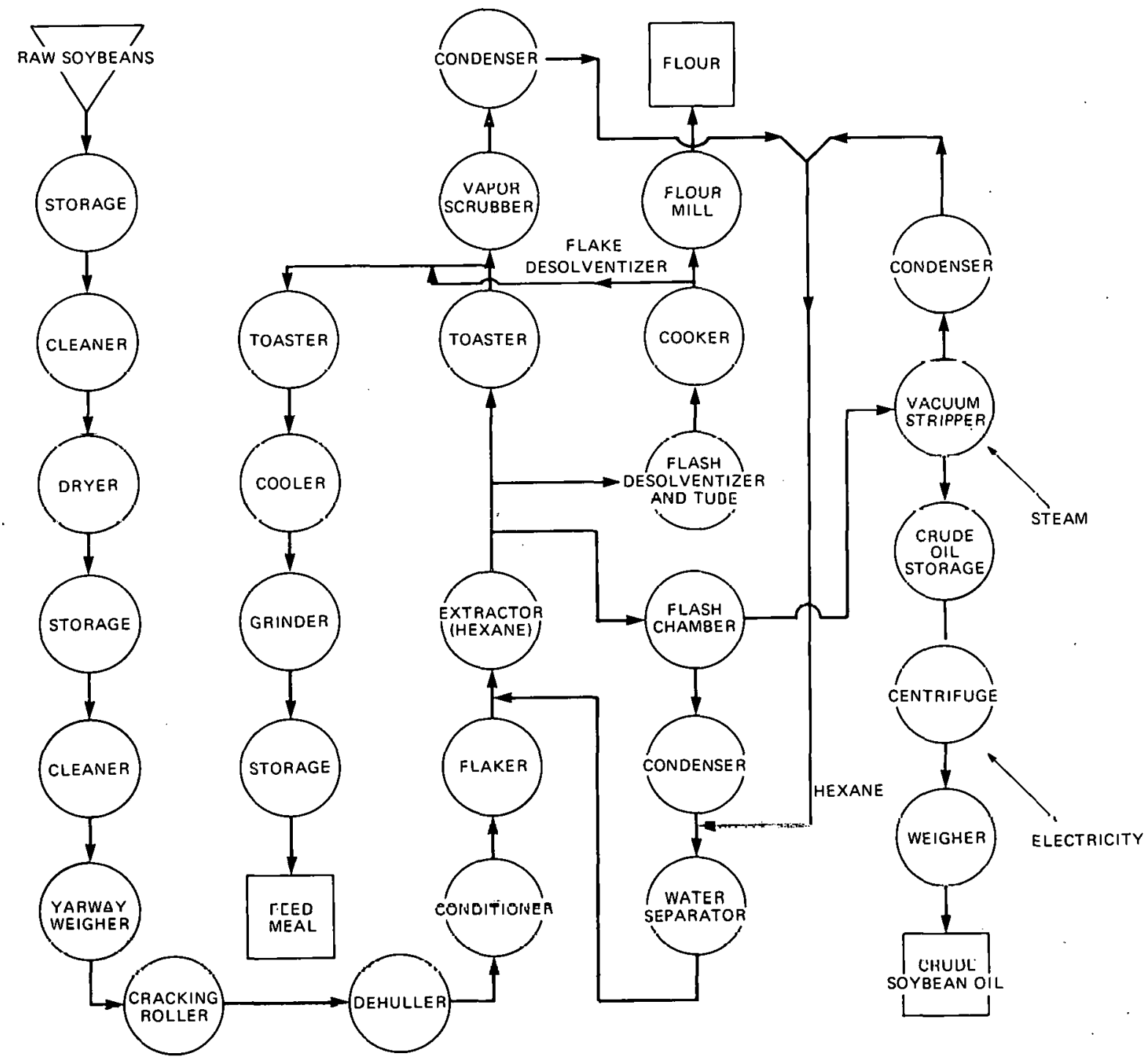

Fig. 4.29. Process flow sheet for the production of soybean oil and meal (SIC 2075) (Kef. 6).

\section{References}

1. The Institute of Fue1, Total Energy Conference Brighton 1971, Proceedings, Vol. 1, London, 1971.

2. A. J. Miller et al., Use of Steam Electric Power Plants to Provide Thormal Energy to Urban Areas, ORNL/HUD-14, Oak Ridge National Laboratory, 1971.

3. Thermo Electron Corporation, A Study of Inplant Electric Power Generation in the Chemical, Petroleum Refining and Paper and Pulp Industries, TE5429-97-76, 1976. 
4. National Consumer Research Institute, Proceedings of the ERDA Conference on Cogeneration and Integrated Energy/Utility Systems, CONF$770632,1977$.

5. Intertechnology Corporation, Analysis of the Economic Potential of solar Thermal Energy to Provide Industrial Process Heat, Vol. 1, Final Report, Report 00028-1 (NTIS C002829/1) (February 1977).

6. Survey of the Applications of Solar Thermal Energy Systems to Industrial Process Heating, Vol. 2, Industrial Process Heat Survey, TID 27348/2, Battelle Laboratories (January 1977).

7. V. 0. Haynes, Energy Use in Petroleum Refineries, ORNL/TM-5433, Oak Ridge National Laboratory, 1976.

8. J. T. Reding and B. P. Shepherd, Energy Consumption: Fuel Utilization and Conservation in Industry, EPA-650/2-75-032d, Dow Chemical Company, Freeport, Tex. (August 1975).

9. Potential for Energy Conservation in the Steel Industry, FEA/D-75/ 402, Battelle Columbus Laboratories, 1975.

10. H. E. McGannon, ed., The Making, Shaping and Treating of Steel, Ninth Ed., United States Steel Corporation, Pittsburgh, Pa., 1971.

11. Voluntary Industrial Energy Conservation - Progress Report No. 5, U.S. Department of Commerce, Office of Energy Programs, and Federal Energy Administration, Office of National Energy Conservation Program (July 1977).

12. Federal Energy Administration, The Data Base - The Potential Energy Conservation in Nine Selected Industries, Vol. 5, Aluminum, Conservation Paper No. 13, Office of Industrial Programs, 1975.

13. E. H. Hall et al., Evaluation of the Theoretical Potential for Energy Conservation in Seven Basic Industries, FEA/D-75/CE1, Battelle Columbus Laboratories, 1975.

14. P. F. Chapman, "The Energy Costs of Producing Copper and Aluminum from Primary Sources," Met. Mater. (February 1974).

15. P. F. Chapman, The Energy Costs of Producing Copper and Aluminum from Primary Sources, Open University, Energy Research Group, Report No. ERG 001 (December 1973).

16. P. F. Chapman, "Energy Conservation and Recycling of Copper and Aluminum," Met. Mater. (June 1974).

17. P. F. Chapman, The Energy Costs of Producing Copper and Aluminum from Secondary Sources, Open University, Energy Research Group, Report No. ERG 002 (October 1973).

18. J. C. Bravard, H. B. Flora II, and C. Portal, Energy Expenditures Associated with the Production and Recycle of Metals, Oak Ridge National Laboratory, ORNL/NSF/EP-24 (November 1972).

19. H. H. Kellogg, "Energy Efficiency in the Age of Scarcity," J. Met. (June 1974). 
20. H. H. Kellogg and J. Tien, "Energy Considerations in Metal Production, Selection, and Utilization," paper presented at the AIME Meeting, Chicago, I11. (Oct. 2, 1973).

21. Federal Energy Administration, The Data Base - The Potential for Energy Conservation in Nine Selected Industries, Vol. 4, Copper, Conservation Paper No. 12, Office of Industrial Programs, 1975.

22. U.S. Bureau of Census, Census of Manufacturers, 1972, Special Report Series: Fuels and Electric Energy Consumed, MC72(SR)-6, U.S. Government Printing office, Washington, D.C., 1973.

23. Dow Chemical Company, Evaluation of New Energy Sources for Process Heat, NSF-OEP 74-18055-1 (PB-245604), Midland, Mich. (September 1975).

24. International Research and Technology Corporation, Industrial Energy Study of the Industrial Chemicals Group, IRT-342-R (PB-236322) (August 1974).

25. Federal Energy Administration, The Data Base - The Potential for Energy Consemation in Nine Selected Industries, Vol. 9, Styrene Butadiene Rubber, Conservation Paper No. 17, Office of Industrial Frograms, 1975.

26. Federal Energy Administration, The Data Base - The Potential for Energy Conservation in Nine Selected Industries, Vol. 1, Selected Plastics, Conservation Paper No. 9, Office of Industrial Programs, 1975.

27. "News from Union Carbide," The Wall Street Joumal (Nov. 28, 1977).

28. Federal Energy Administration, The Data Base - The Potential for Energy Conservation in Nine Selected Industries, Vol. 2, Petroleum Refining, Conservation Paper No. 10, Office of Industrial Programs, 1975.

29. Federal Energy Administration, The Data Base - The Potentiat for Energy Conservation in Nine Selected Industries, Vol. 8, Selected Paper Products, Conservation Paper No. 16, Office of Industrial Programs, 1975.

30. Dow Chemical Company, Energy Consumption: Paper, Stone/CZay/GZass/ concrete and k'ood Industries, EPA-650/2-75-032-c, 1975.

31. Federal Energy Administration, The Data Base - The Potential for Energy Conservation in Nine Selected Industries, Vol. 3, Cement, Conservation Paper No. 11, Office of Industrial Prograns, 1975.

32. Min. Congr. J. (December 1975).

33. Federal Energy Administration, The Data Base - The Potential for Energy Conservation in Nine Selected Industries, Vol. 7, Glass, Conservation Paper No. 15, Office of Industrial Programs, 1975.

34. Industrial Energy Study of Selected Food Industries, FEA-EI-1652 (PB-237316), Development Planning and Research Associates (July 1974). 
5. ANALYSIS OF GAS-TURBINE COGENERATION SYSTEMS FOR SELECTED INDUSTRIES AND PROCESSES

An essential test of feasibility for the CCC is its application to specific case studies from which realistic estimates of fuel utilization can be procured. Insight into the equipment requirements can also be gained. Such case studies, if carried out in sufficient detail, would reveal the economic viability of the system; however, the studies in this report are prellminary and primarily demonstrate the thermodynamic feasibility of the CCC. Where information is sufficient, the practicability of the system is discussed. The conceptual systems that are evolved in this section were not necessarily optimized for fuel utilization, and cases where improvement is possible are noted.

\subsection{Analysis of Fluidized-Bed Furnace}

Mass and energy balances must be performed on the furnace in some detail in order to arrive at a furnace efficiency, that is, the degree to which the energy in the coal can be transferred to the power system. The basic ground rules for the furnace are listed in Table 5.1, and the basic furnace system layout is shown in Fig. 5.1.

Data available in the literature indicated that at $871^{\circ} \mathrm{C}\left(1600^{\circ} \mathrm{F}\right)$, a calcium/sulfur ratio of 4 would be satisfactory for the $90 \%$ sulfur retention warranted by the $\mathrm{SO}_{2}$ emission regulations of the EPA. ${ }^{1}$ The furnace analysis included losses from the coal and limestone dryers, carbon loss caused by incomplete combustion, and calcination and sulfation reactions. A loss of $0.2 \%$ was assumed for radiation. Thermal input from the induced- or forced-draft fans required with the furnace system was not considered in this analysis. The calculated energy losses are summarized in Table 5.2. The $86 \%$ efficiency, as indicated in Table 5.2, results in $24,832 \mathrm{~kJ}$ per $\mathrm{kg}(10,676 \mathrm{Btu}$ per $\mathrm{lb})$ of dry coal available to the power system. An analysis in another study using a similar system resulted in a comparable value for furnace efficiency. ${ }^{2}$

Combustion air is heated regeneratively to $4449^{\circ} \mathrm{C}\left(840^{\circ} \mathrm{F}\right)$ with heat from the flue gases. Higher degrees of regeneration are perhaps possible, but the following reasons dictated the selected values. 
Table 5.1. Basis for furnace calculations

\begin{tabular}{ll} 
Fluidized-bed temperature, ${ }^{\circ} \mathrm{C}\left({ }^{\circ} \mathrm{F}\right)$ & $871(1600)$ \\
Excess alr, \% & 15 \\
Calcium/sulfur ratio & 4 \\
Sulfur retention, \% & 90 \\
Sulfur content of dry coal (Illinois No. 6), \% & 4.5 \\
Mulsture in coal, \% & 13.0 \\
Combustion efficiency, \% & 99 \\
Combustion air relative humidity at $16^{\circ} \mathrm{C}\left(60^{\circ} \mathrm{F}\right), \%$ & 60 \\
l.jmestone moisture, $\%$ & 5 \\
Coal higher heating value, $\mathrm{kJ} / \mathrm{kg}(\mathrm{Btu} / 1 \mathrm{~b})$ dry coal & $28,842(12,400)$ \\
\hline
\end{tabular}

Table 5.2. Summary of energy losses in fluidized-bed furnaces

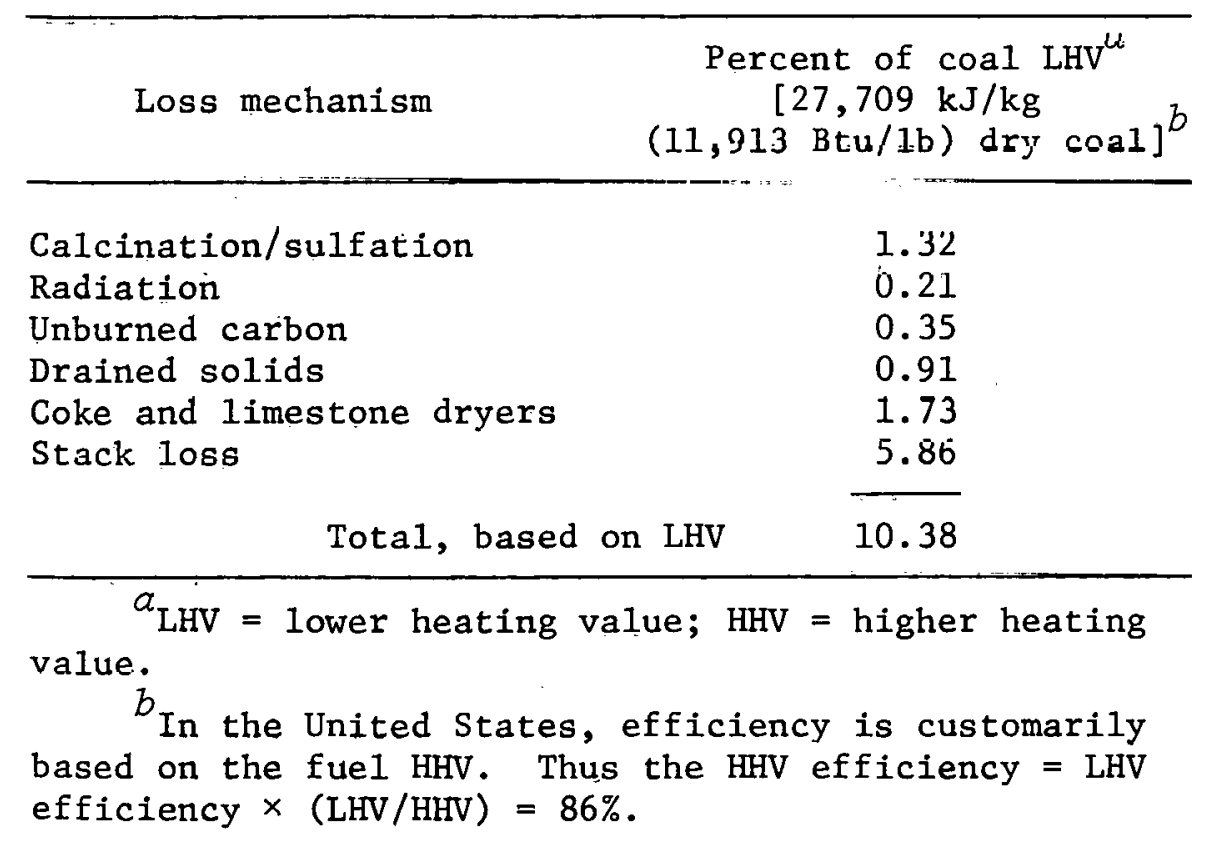




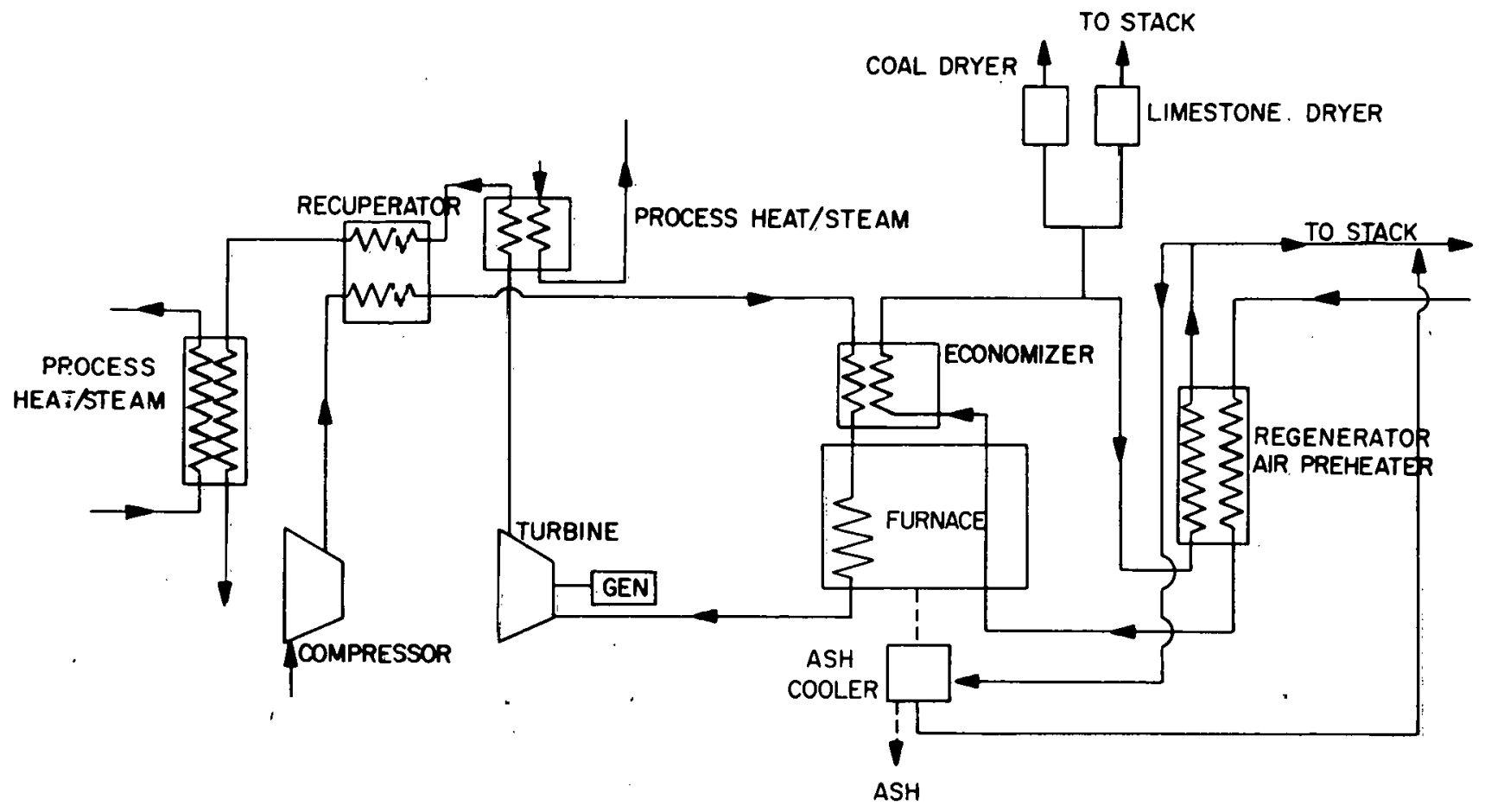

Fig. 5.1. Atmospheric fluidized-bed gas-turbine cogeneration system. 
1. The recuperator effectiveness is $283 \%$; higher effectiveness would greatly increase cost.

2. Higher incoming combustion air temperatures lead to materials problems in the air tuyere plate.

3. Stack gas temperature of $\sim 149^{\circ} \mathrm{C}\left(300^{\circ} \mathrm{F}\right)$ was desired.

The flue-gas temperature leaving the economizer depends on the amount of heat transferred to the power system air while in the economizer. A trade-off exists between the surface area required in the economizer and the undesirable aspects of piping extremely hot flue gases. A compromise value of $538^{\circ} \mathrm{C}\left(1000^{\circ} \mathrm{F}\right)$ was chusen arbitrarily. I'he flue gases are cooled to $\sim 132^{\circ} \mathrm{C}\left(270^{\circ} \mathrm{F}\right)$ in the air preheater (Fig. 5.1). Part of these gases cuul the drained snitids to $0.204^{\circ} \mathrm{C}\left(400^{\circ} \mathrm{F}\right)$ and then reenter the stack-gas stream, resulting in a final exit temperature of $\sim 149^{\circ} \mathrm{C}\left(300^{\circ} \mathrm{F}\right)$.

Several power system parameters were also fixed for the analysis. These are enumerated in Table 5.3, where the given compressor and turbine efficiencies are noted as conservative.

l'able 5.3. Yower system fixed parameters

\begin{tabular}{ll} 
Turbine inlet temperature, ${ }^{\circ} \mathrm{C}\left({ }^{\circ} \mathrm{F}\right)$ & 816 (1500) \\
Turbine efficiency, \% & 82 \\
Compressor efficiency, $\%$ & 80 \\
System pressure drop, $\triangle \mathrm{P} / \mathrm{P}, \%$ & 10 \\
Generator electrical efficiency, \% & 97 \\
Working fluid & Dry air \\
\hline
\end{tabular}

Potential locations for extracting process heat from the flow streams are indlcated in Fig. 5.1. Note that utilizing the flue gases for indirect process heat in lieu of regenerative heating is possible. This practice, instead of extracting all process heat from the power system, would tend to reduce the heat-exchanger surface area in the furnace. In general, however, the available heat in the flue gases which can be extracted is rather small. 
The merits of closing the power cycle are evident in cases of variable electrical load because a closed-cycle system can maintain its electrical output effectiveness at reduced loads, that is, the heat/power ratio would remain constant. The open-cycle system at reduced electrical load would tend to increase in heat/power ratio. Industrial loads considered in this study are assumed to be rather constant, allowing the use of the more simple open cycle. An excellent discussion of the relative merits of the open and closed systems is available in Ref. 2 .

\subsection{Industries Selected for Application}

Several factors influenced the choice of industries or processes to be analyzed: (1) completeness of available data on process energy, (2) apparent practicality of application, (3) thermodynamic interface with the CCC, and (4) energy intensiveness of industry. For these studies, the CCC needed to be capable of supplying $100 \%$ of the industrial process energy requirements. Electrical powèr is generally overproduced to allow for the furnace auxiliary power consumption.

\subsubsection{Chemical industries}

Investigated from the chemicals group were high-density polyethylene (HDPE), styrene butadiene rubber (SBR), and chlorine/caustic soda.

5.2.1.1 HDPE production system. Energy requirements for HDPE production wcre summarized in Table 4.18. The heat/power ratio is seen to be about 3.3, and, by referring to Fig. 4.6, a proper system may be ascertained. The use of a recuperator is mandatory for adequate electrical output if the overall fuel utilization is to be high. The plant was assumed to. produce a primary product, excluding extrusion and pelletization. A summary of the performance of the contrived system (Fig. 5.2) is provided in Table 5.4. The heat and power requirements appear to place this application out of capabilities of a conventional back-pressure steam system. Note also that a portion of the process heat ultimately appears as hot air (see Figs. 4.18 through 4.21). Although the system derived 


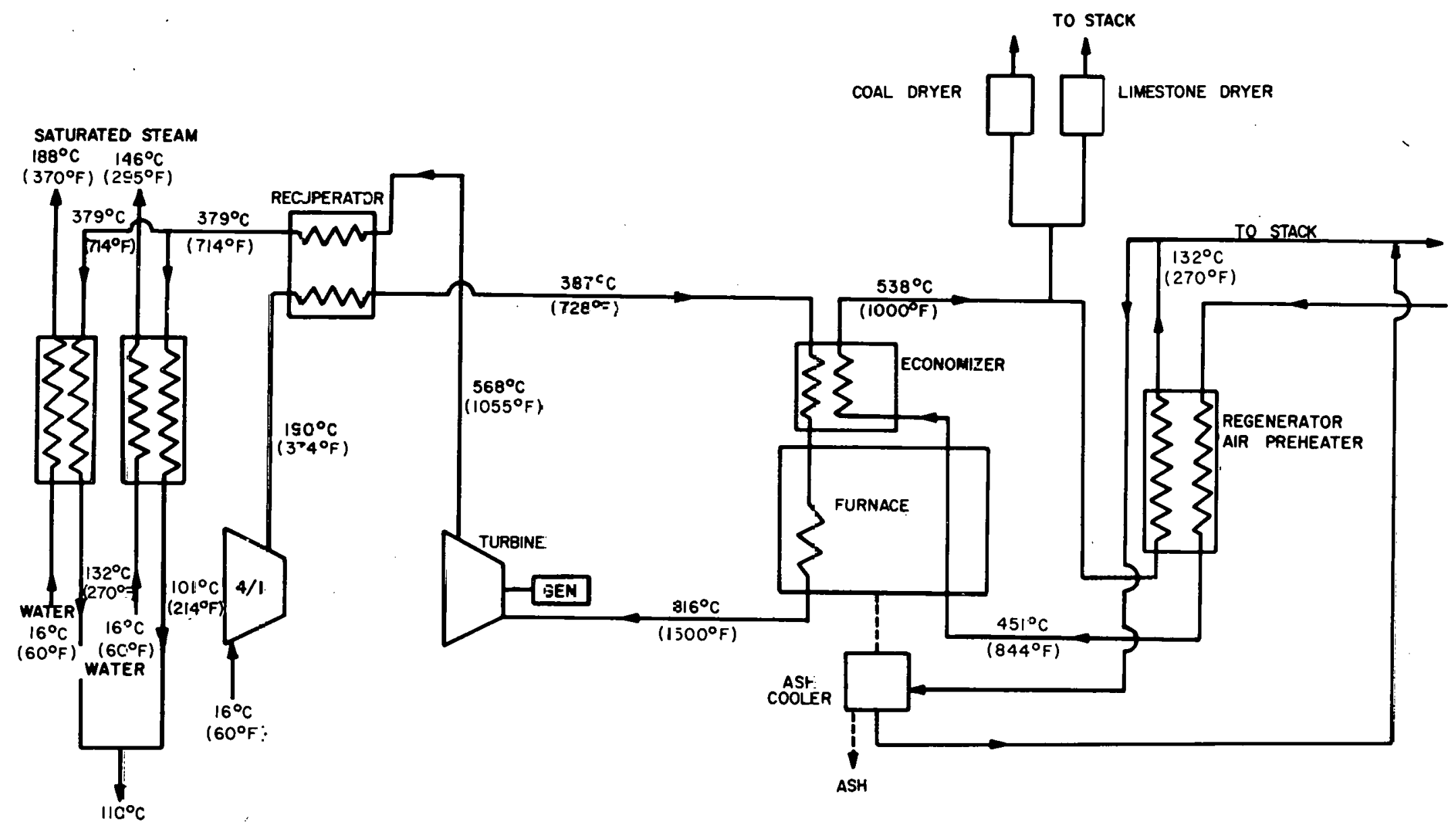

Fig. 5.2. CCC cageneration system for the HDPE industry. 
Table 5.4. System parameters per metric ton (ton) of HDPE

\begin{tabular}{|c|c|}
\hline \multicolumn{2}{|l|}{ Steam, kg (1b) } \\
\hline $\begin{array}{ll}\text { Required, } & 188^{\circ} \mathrm{C}\left(370^{\circ} \mathrm{F}\right) \\
& 146^{\circ} \mathrm{C}\left(295^{\circ} \mathrm{F}\right) \\
\text { Produced } & \end{array}$ & $\begin{array}{ll}300 & (600) \\
825 & (1,650) \\
\text { All } & \end{array}$ \\
\hline \multicolumn{2}{|l|}{ Electricity, $\mathrm{kWhr}$} \\
\hline $\begin{array}{l}\text { Required } \\
\text { Produced }\end{array}$ & $\begin{array}{ll}220 & (200) \\
303 & (275)\end{array}$ \\
\hline Compressor pressure ratio & 4.0 \\
\hline Power a1r flow, kg (1b) & $10,800 \quad(21,600)$ \\
\hline Coal feed rate (dry), $\mathrm{kg}(1 \mathrm{~b})$ & $207.8(415.5)$ \\
\hline Recuperator effectiveness, $\%$ & 49 \\
\hline Overall thermal utilization, $\%$ & 69.1 \\
\hline Used heat/power ratio & 2.67 \\
\hline
\end{tabular}

here generates steam as is presently used, the system's hot air supply could be used directly.

The overall power air exit temperature is $\sim 110^{\circ} \mathrm{C}\left(230^{\circ} \mathrm{F}\right)$, higher than desired. The generation of steam using hot gas requires consideration of the "pinch point" in the waste-heat boiler. This characteristic of waste-heat boilers tends to increase the required air flow in order to maintain a pinch-point temperature difference of $\sim 14$ to $17^{\circ} \mathrm{C}$ (20 to $30^{\circ} \mathrm{F}$ ). In this case, however, a little less recuperation would appear to increase the overall utilization.

With this system, the specific energy of HDPE production is $\sim 6001$ $\mathrm{kJ} / \mathrm{kg}(2580 \mathrm{Btu} / \mathrm{lb})$ of HDPE based on the coal feed rate. This would be lowered if part of the steam condensate were returned to the boiler feed line. The amount of condensate that is reused was unavailable in this industry, as well as in most others. For this reason, the boiler feeds are always assumed to be fresh cold water.

About $93 \%$ of the HDPE production capacity is located in Texas and Louisiana, with the average plant producing $\sim 11.8$ metric tons (13 tons) $/$ hr (300 days/year, $24 \mathrm{hr} /$ day). ${ }^{3}$ There are about 15 facilities in the 
United States for production of HDPE. The average furnace size for a cogeneration system would be $220 \mathrm{MW}(t)$.

5.2.1.2 Styrene butadiene rubber. The steam energy requirements were converted to flow values for use in this analysis. Information for the system shown in Fig. 5.3 is presented in Table 5.5. The specific energy of the SBR production is $210,583 \mathrm{~kJ} / \mathrm{kg}(4,550 \mathrm{Btu} / \mathrm{lb})$ of $\mathrm{SBR}$. If the electricity had been produced at a central station with an efficiency of $35 \%$ and the steam generated in boilers at $86 \%$, the specific energy would be $410,932 \mathrm{~kJ} / \mathrm{kg}(4,700 \mathrm{Btu} / \mathrm{lb})$.

Table 5.5. System parameters per metric ton (ton) of SBR

\begin{tabular}{ll}
\hline Steam, kg (1b) & \\
Required, $121^{\circ} \mathrm{C}\left(250^{\circ} \mathrm{F}\right)$ & $1,787(3,574)$ \\
Produced & $544(1,088)$ \\
Electricity, kWhr & $\mathrm{All}$ \\
Required & $464(421)$ \\
$\quad$ tiruduced & $j 26(4 / 1)$ \\
Compressor pressure ratio & 4.0 \\
Power air flow, kg (1b) & $19,420(38,840)$ \\
Coal feed rate (dry), kg (1b) & $366.8(733.6)$ \\
Recuperator effectiveness, $\%$ & 52 \\
Overall thermal utilization, $\%$ & 76.0 \\
Used heat/power ratio & 3.24 \\
\hline
\end{tabular}

Texas and Louisiana dominate production of SBR with $287 \%$ of U.S. production capacity. ${ }^{\circ}$ Uperating 300 days/year and $24 \mathrm{hr} /$ day, the average Gulf Coast plant produces 21.3 metric tons $(23.5$ tons $) / \mathrm{hr}$. SBR is produced at 14 plants that would require average cogeneration systems of G3 MW(L) each.

Obviously, the rubber and plastics production is located near the source of abundant gas and oil fuels and petrochemical feedstocks. The economics of importing coal into these areas is certainly a valid concern. 


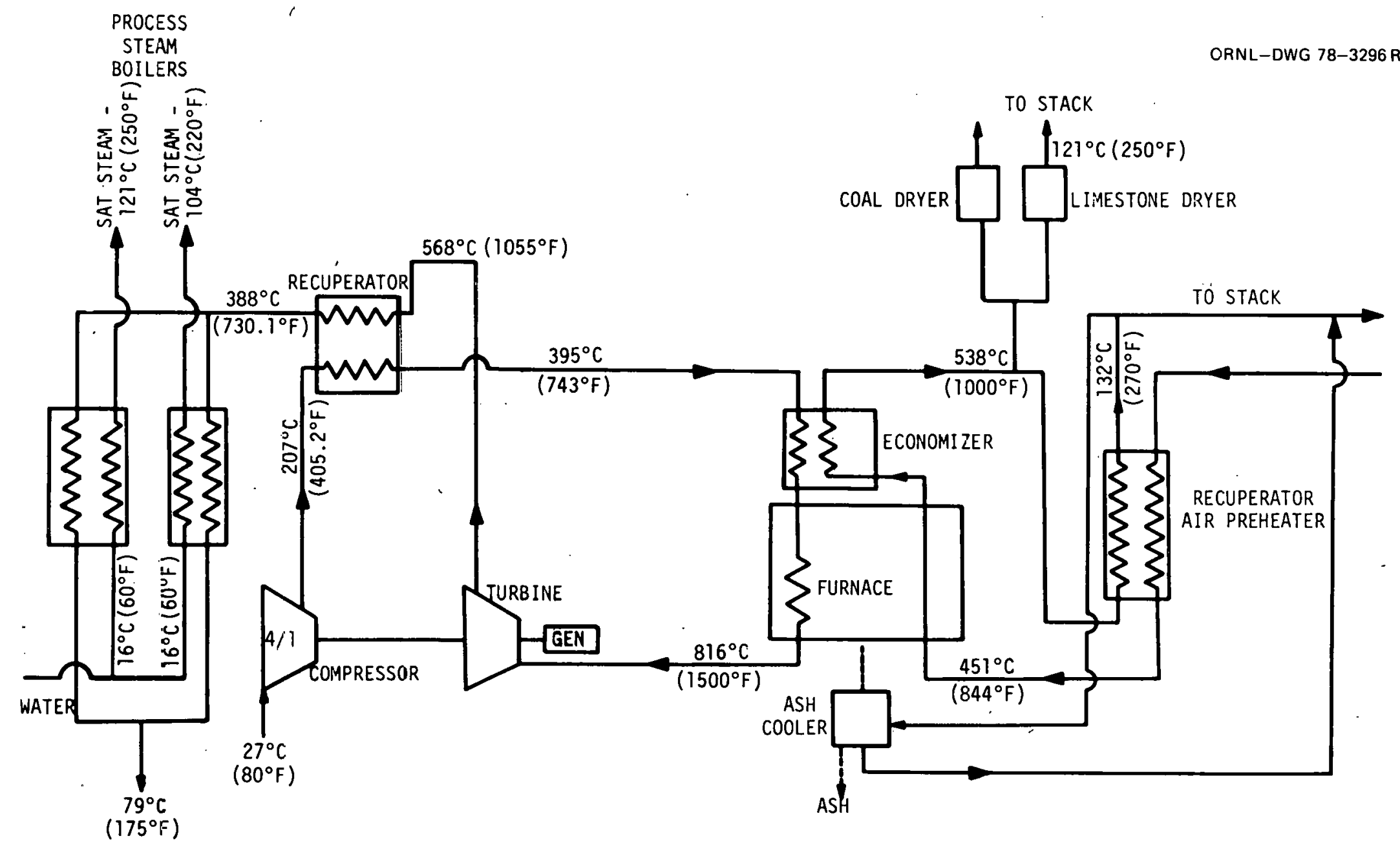

Fig. 5.3. CCC cogeneration system for the SBR industry. 
5.2.1.3. Chiorine and caustic soda. In the recent past, there have been market shortages of both chlorine and caustic soda. These are caused by a lack of production capacity and also, to a lesser extent, the periodic unavailability of sufficient electric power. ${ }^{4}$ The electric demand of the industry is so high that thermal utilization in the CCC was less than $60 \%$. - The present state-of-the-art systems in the industry are reported to operate with considerably lower utilizations, with perhaps one large plant approaching 55\% utilization. ${ }^{4}$ The plant chosen is a diaphragm cell production facility. Mercury cells require no steam and thus are not likely to implement total energy systems.

The flow sheet for the derived system, shown in Fig. 5.4, is described in Table 5.6. In cases of high power demand such as this, the option of a combined cycle (gas-turbine topping, steam bottoming) cannot be ignored.

Table 5.6. System parameters per metric ton (ton) chlorine and 1.12 metric ton (ton) caustic soda

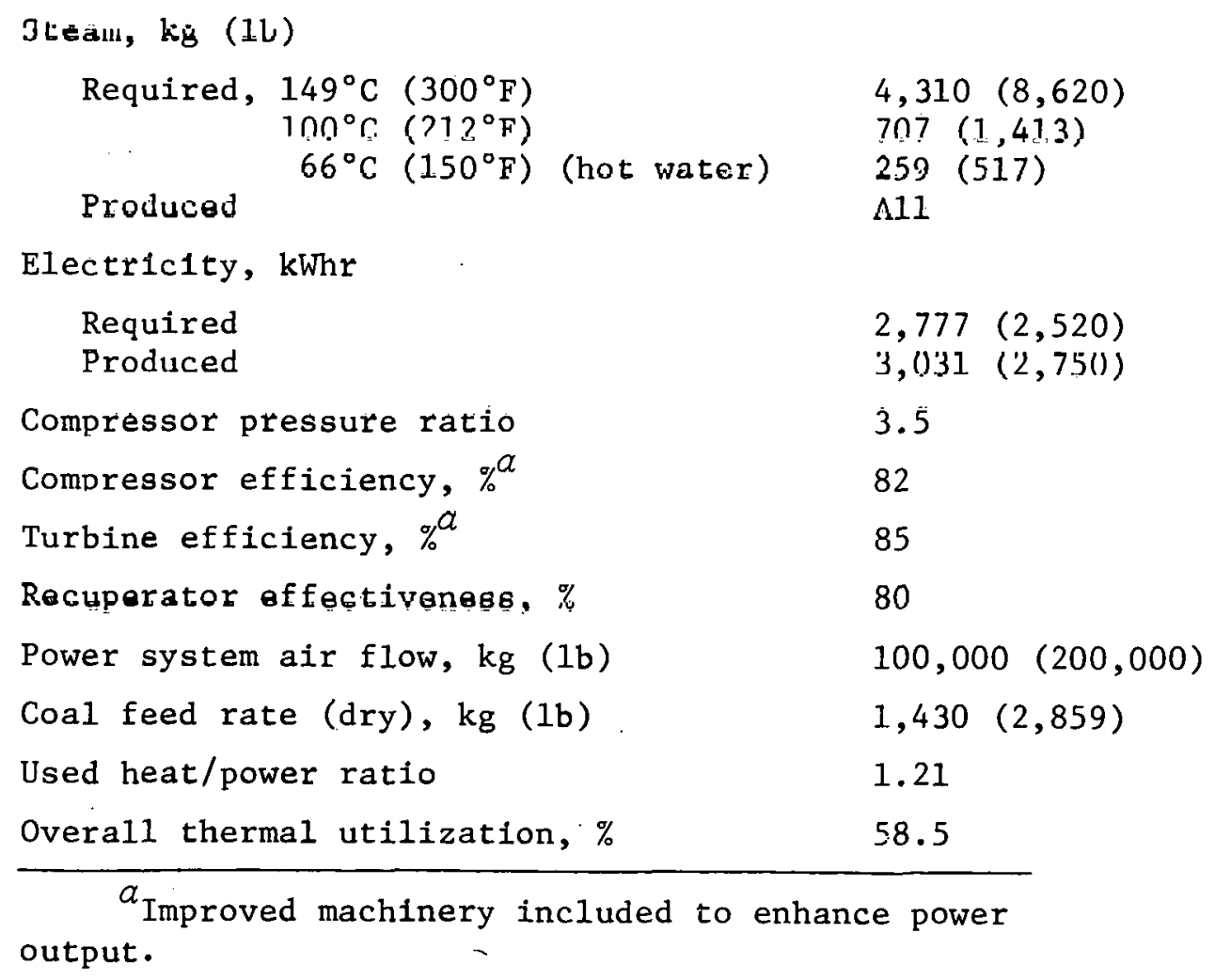




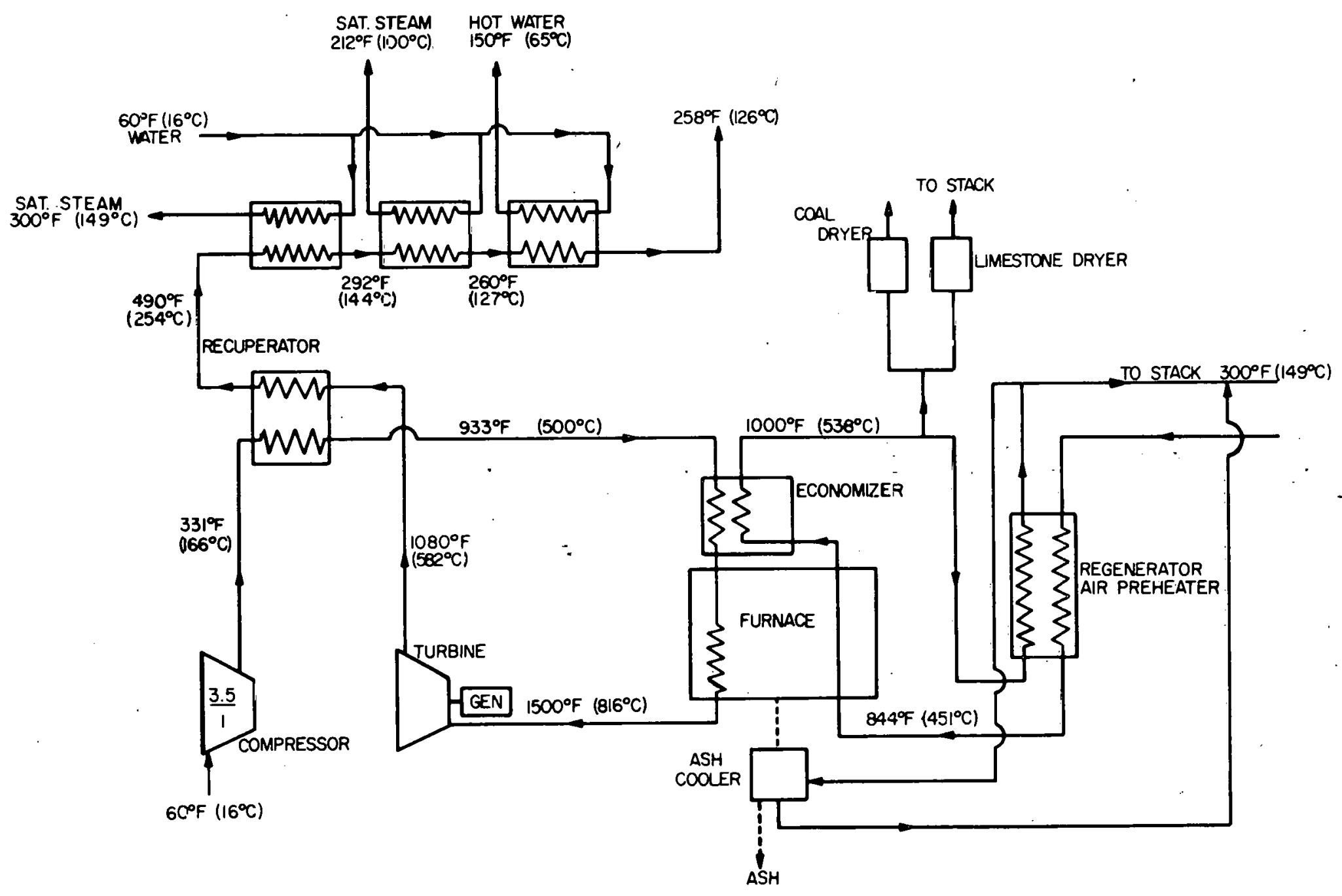

Fig. 5.4. CCC cogeneration system for the caustic soda-chlorine industry. 
The specific energy for one electrochemical unit (ecu)* is 18,612 $\mathrm{kJ}(17,726 \mathrm{Btu})$. A value typical of the industry today is $\sim 20,836 \mathrm{~kJ} / \mathrm{ecu}$ $(19,750 \mathrm{Btu} / \mathrm{ecu})$ with purchased electricity. ${ }^{4}$

There are 264 chlorine/caustic plants in the United States which produced $\sim 15.1 \times 10^{6}$ metric tons $\left(16.6 \times 10^{6}\right.$ tons) (ecu) in $1974 .{ }^{3}$ For a 300 day year and $24 \mathrm{hr} /$ day, the average production is 32.7 metric tons (36 ecu tons)/hr. The average CCC installation size would be $\sim 374 \mathrm{MW}(t)$, requiring four 90-MW(t) units per plant, totaling 256 90-MW units in the United states. The production of chlorine/caustic is carried out in all parts of the United States, with Louisiana possessing the greatest concentration of capacity at $17 \%$ of the total. Expenditures for new equipment lulalled $\$ 28.5$ million in $14 \%$, which indicatcs an interest ill new concepts that might pay for themselves over time. ${ }^{4}$

\section{2 .2 Paper/pulp - newsprint}

Newsprint is, of course, only one of several qualities of paper that can be manufactured from pulp. Newsprint production was $25.3 \%$ of the total paper and paper-board production for $1974 .^{5}$ The variety of integrated pulp and paper mills results in high uncertainty as to the application or need for new cogeneration systems. Much of the fuel requirements are satistied by the burning of bark, wood scrap, and various liquors arising from the pulping process. For this reason, a noninte- . grated paper mill in which dry pulp is a raw material was chosen for the application. There are about equal numbers of integrated and nonintegrated paper mills in the United States. ${ }^{3}$ A process flow diagram for convcrting dry pulp into finished paper is shown in Fig. 5.5.

The process energy requirements for this particular plant operation were derived from data in Refs. 3 and 5. A diagram of the cogeneration system is presented in Fig. 5.6, and the pertinent data are given in Table 5.7.

The specific energy for newsprint production is about $4701 \mathrm{~kJ} / \mathrm{kg}$ (4053 Btu/IV) of newsprine. The 1975 newsprint production was expected

\footnotetext{
* One ecu here means one ton of chlorine plus 1.12 tons of caustic soda ( 1 ton $=0.9078$ metric ton) .
} 


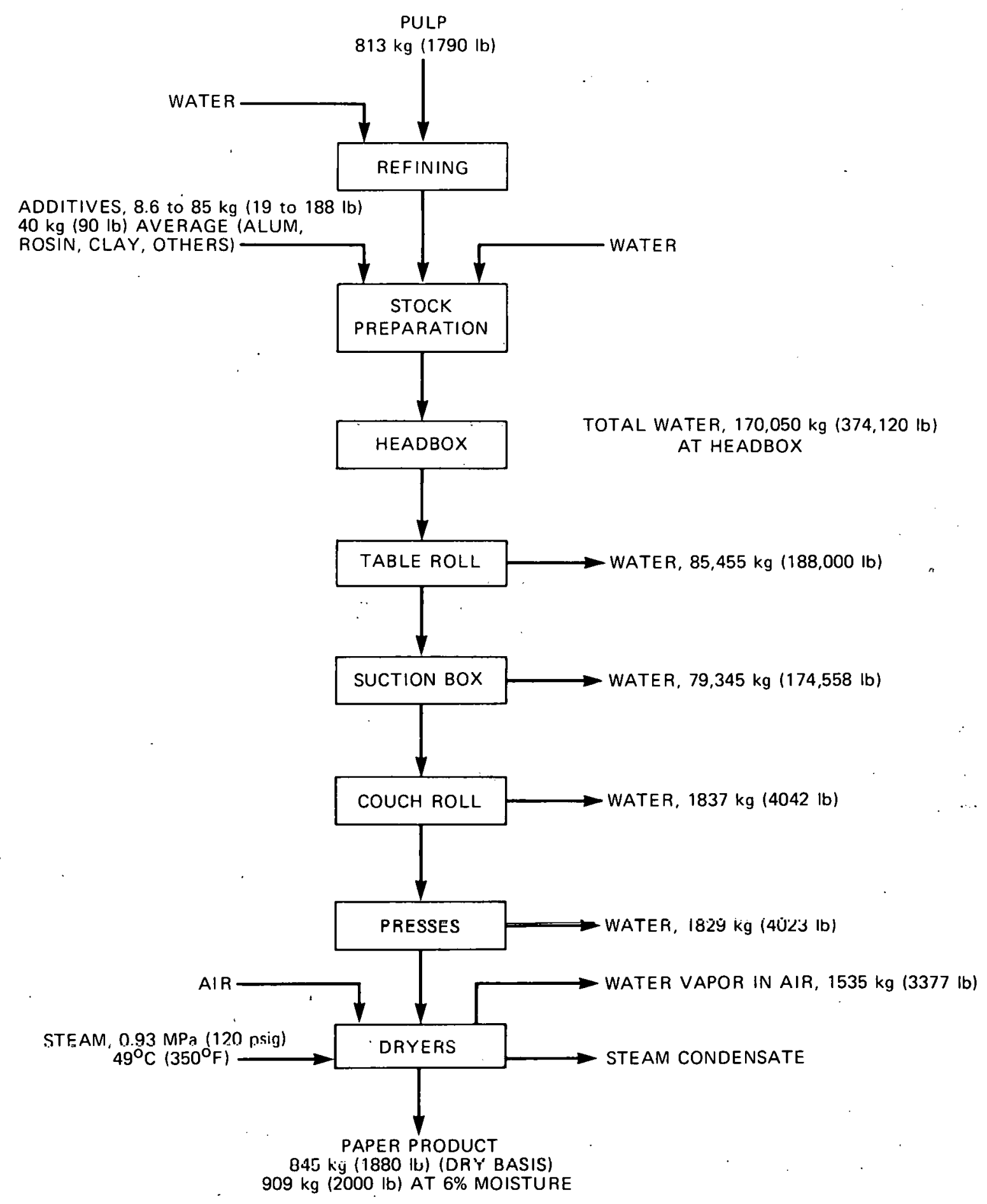

Fig. 5.5. Refining, stock preparation, and papermak1ng ( $1 \mathrm{lb}=$ $0.454 \mathrm{~kg}$ ) (Ref. 3). 


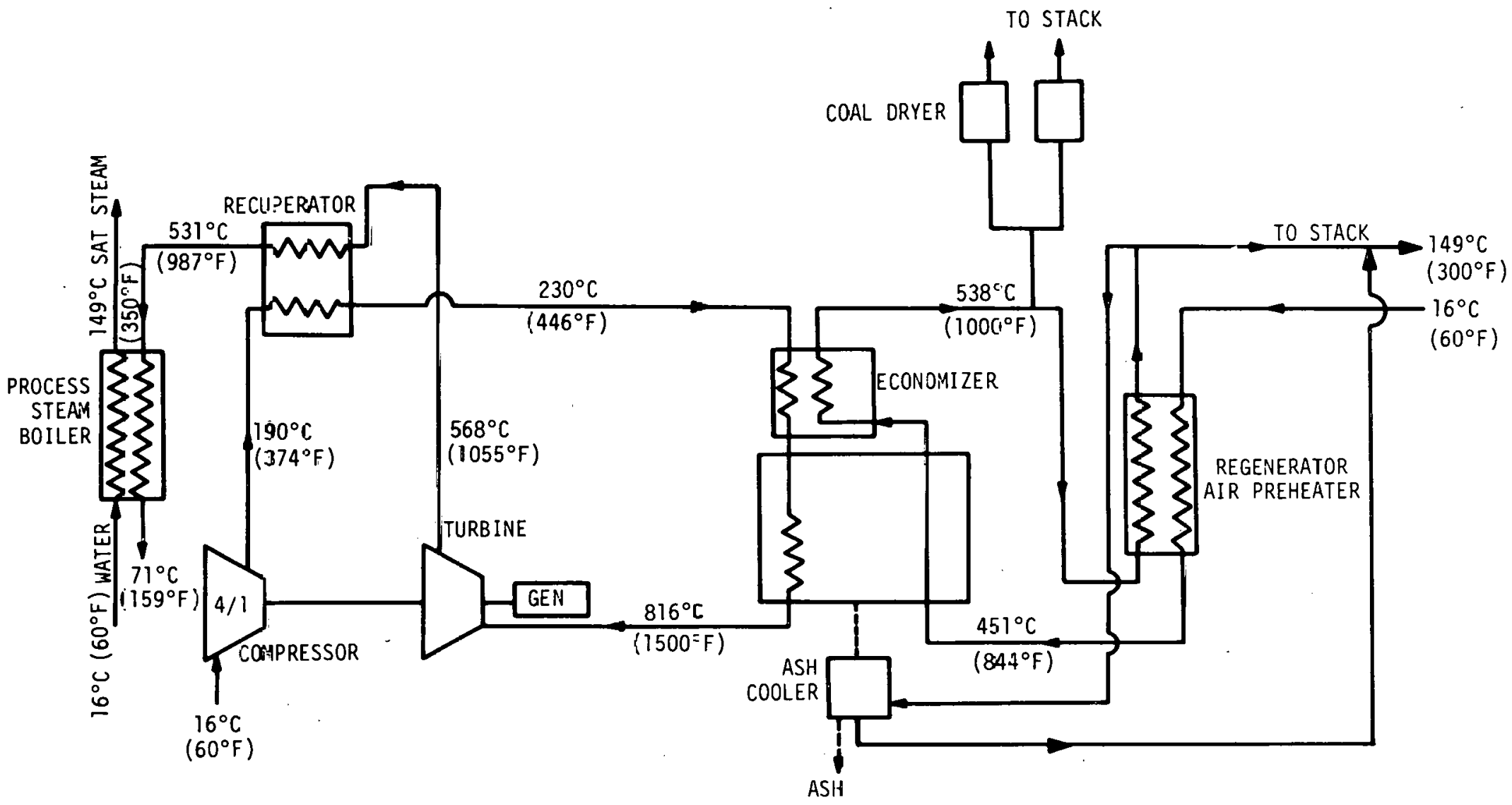

Fig. 5.6. CCC cogeneration system for the newsprint industry. 
Table 5.7. System parameters per metric ton (ton) of newsprint

$\begin{array}{ll}\begin{array}{l}\text { Steam, } \mathrm{kg}(1 \mathrm{~b}) \\ \text { Required, } 177^{\circ} \mathrm{C}\left(350^{\circ} \mathrm{F}\right)\end{array} & \begin{array}{l}2,250(4,500) \\ \text { All }\end{array} \\ \begin{array}{l}\text { Produced } \\ \text { Electricity, kWhr }\end{array} & 330.6(300) \\ \quad \begin{array}{l}\text { Required } \\ \text { Produced }\end{array} & 366(332) \\ \text { Compressor pressure ratio } & 4.0 \\ \text { Recuperator effectiveness, \% } & 10 \\ \text { Power system air flow, } \mathrm{kg}(\mathrm{Ib}) & 12,650(25,300) \\ \text { Coal feed rate (dry), } \mathrm{kg}(1 \mathrm{~b}) & 362.9(653.7) \\ \text { Used heat/power ratio } & 4.62 \\ \text { Overall thermal utilization, } \% & 78.6\end{array}$

to he about $3.8 \times 10^{6}$ tons, $^{3}$ or 479 metric tons (528 tons)/hr (300 days/ year, $24 \mathrm{hr} /$ day), which would require $14 \mathrm{CCC}$ units rated at $90 \mathrm{MW}(\mathrm{t})$. About 197 nonintegrated paper mills exist in the country, ${ }^{3}$ but the number involved in making newsprint instead of writing paper is uncertain. The manufacture of writing paper is very similar to making newsprint, involving the same basic production sequence. The production of writing paper is more energy intensive, however, requiring about $350 \mathrm{kWhr}$ and $4800 \mathrm{~kg}$ steam/metric ton $\left(9600 \mathrm{lb}\right.$ steam/ton) of finished paper. ${ }^{5}$ Another interesting statistic is that, including all types of paper/pulp facilities, there are 538 plants with no in-house electricity generation. ${ }^{3}$ Furthermore, at least $36 \%$ of these plants are located in regions where coal is a major power source. A potentially sizable market for the CCC exists in these plants that have no total energy package at present.

\subsubsection{Petroleum refining}

Petroleum refining involves many diverse processes, as indicated in Section 4.3.3. Two processes were selected for analysis because these were considered to be exceptionally practicable applications. 
Furthermore, they are quite energy intensive among the various processes, with the equipment handling some of the largest flows of oil in a refinery.

5.2.3.1. Atmospheric-pressure distilling column crude-oil preheater. The first step in the manufacture of petroleum products is the separation of the crude oil into the main conventional streams, as indicated in Fig. 5.7. Each stream contains many compounds and boils within a limited range. The crude oil passes through a heat-exchanger train to recover heat from product streams being run down to storage. Often, the crude is piped into a flash drum where light fractions will vaporize and pass directly into the fractionating tower. The balance of the crude is ultimately raised to $2343^{\circ} \mathrm{C}\left(650^{\circ} \mathrm{F}\right)$ in a fired heater and enters the tower, where separation of the crude oil into the required product boiling ranges takes place, controlled by temperature levels and reflux rates throughout the system.

Typical product streams are light gasoline, naphtha, kerosene, diesel or light gas oil, and a bottom product used as a fuel oil blending component.

The crude units generally handle the entire input to the refinery. typically $0.09 \mathrm{~m}^{3} / \mathrm{sec}(50,000 \mathrm{bbl} / \mathrm{day})$. The terminal temperature required for the crude oil entering the column varies in the literature, ${ }^{3,7}$ but $343^{\circ} \mathrm{C}\left(650^{\circ} \mathrm{F}\right)$ was chosen. Heat recovery from the stripping steam usually raises the crude temperature to $\sim 135^{\circ} \mathrm{C}\left(275^{\circ} \mathrm{F}\right)$ before entering the crude heater. The remaining heat is supplied in a pipe still heater, which is usually gas-fired. ${ }^{7}$ The values for electrical requirements of this un1t vary in the literature also, with $3.77 \mathrm{kWhr} / \mathrm{m}^{3}(0.6 \mathrm{kWhr} / \mathrm{bb} 1)$ selected as typical. Using thermodynamic data for oil from Refs. 8 and 9 to perform the heating from 135 to $343^{\circ} \mathrm{C}\left(275\right.$ to $\left.650^{\circ} \mathrm{F}\right)$, it was determined that $501,240 \mathrm{~kJ} / \mathrm{m}^{3}(75,448 \mathrm{Btu} / \mathrm{bb1})$ would be required. The heat/power ratio for the unit then becomes 237 . To meet the heat demand, the CCC must produce a surplus of electricity, which is assumed to be utilized elsewhere in the refinery. There will be waste heat exiting from the heater at $\sim 149^{\circ} \mathrm{C}\left(300^{\circ} \mathrm{F}\right)$, which may or may not be employed for low-temperature process heating. The crude-oil heater was 
ORNL-DWG $79-4921$ ETD

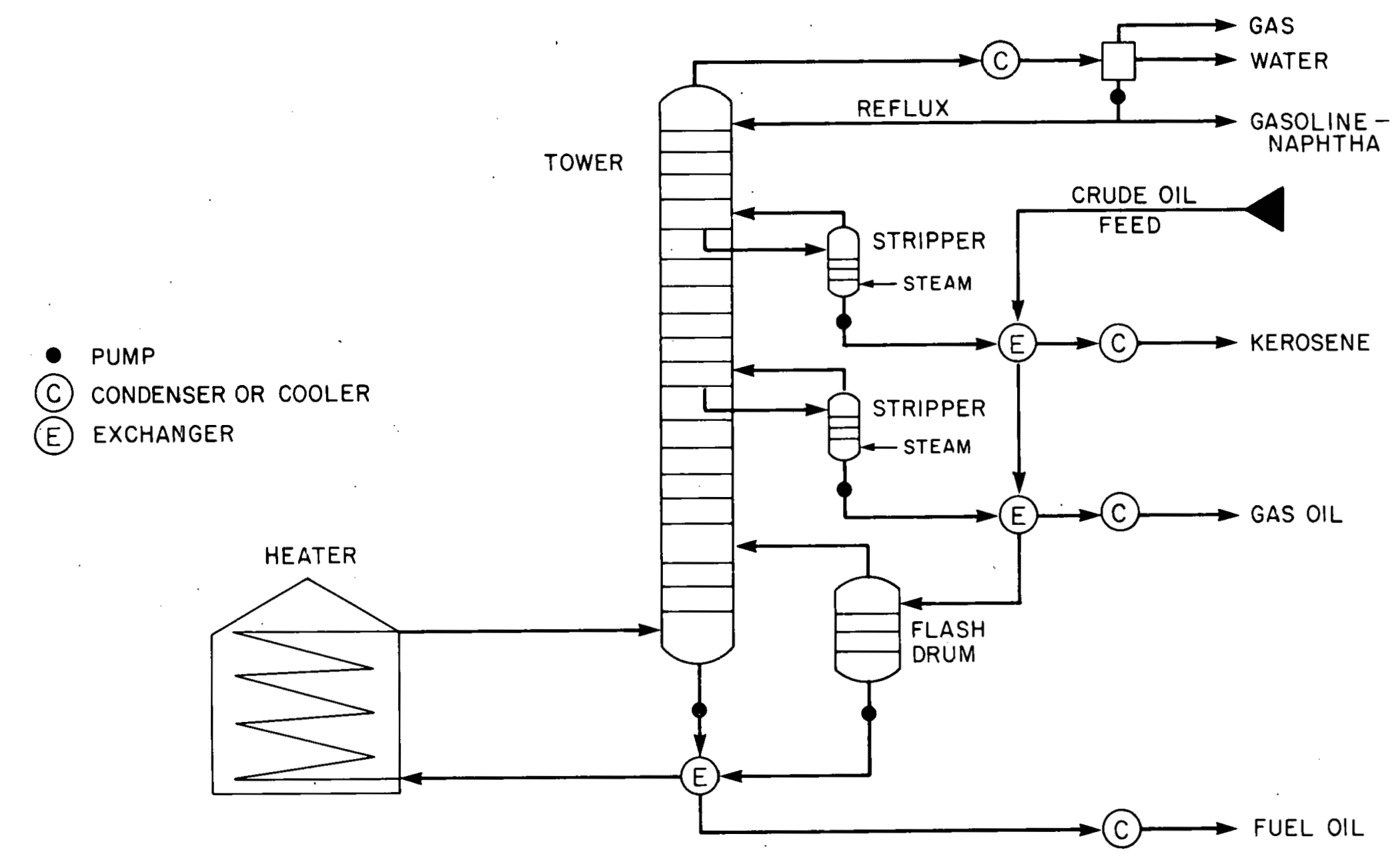

Fig. 5.7. Atmospheric-pressure crude-oil distillation unit (Ref. 6). 
assumed to be a rather conventional counterflow heat exchanger. The CCC system flow sheet is provided in Fig. 5.8, and data for the system are given in Table 5.8 .

Table 5.8. System parameters per cubic meter (barre1) of crude-oil input

\begin{tabular}{|c|c|}
\hline \multicolumn{2}{|l|}{ Therma1. energy } \\
\hline $\begin{array}{l}\text { Required, }{ }^{\alpha} \mathrm{kJ} \text { (Btu) } \\
\text { Produced }\end{array}$ & $\begin{array}{ll}501,240 & (75,448) \\
501,240 & (75,448)\end{array}$ \\
\hline \multicolumn{2}{|l|}{ Electricity, kWhr } \\
\hline $\begin{array}{l}\text { Required } \\
\text { Produced }\end{array}$ & $\begin{array}{l}3.8(0.6) \\
26.2(4.16)\end{array}$ \\
\hline Compressor pressure ratio & 3.0 \\
\hline Recuperator effectiveness, $\%$ & None \\
\hline Oil heater LMTD, ${ }^{\circ} \mathrm{C}\left({ }^{\circ} \mathrm{F}\right)$ & $123(222)$ \\
\hline Power system air flow, kg (1b) & $1,065(372.5)$ \\
\hline Coal feed rate $(\mathrm{dry}), \mathrm{kg}$ (lb) & $31.2(10.9)$ \\
\hline Used heät/outpưt poower rảtió & 5.31 \\
\hline Overall thermal utilization, \% & 66.5 \\
\hline
\end{tabular}

Pipestill heaters reportedly operate at 60 to $70 \%$ fuel efficiency. ${ }^{7}$ A pipestill heater operating at $70 \%$ efficiency and a central power station operating at $36 \%$ efficiency produce the electricity and heat at a fuel cost of $973,000 \mathrm{~kJ} / \mathrm{m}^{3}(147,340 \mathrm{Btu} / \mathrm{bbl})$. The CCC performs the identical duty at $890,000 \mathrm{~kJ} / \mathrm{m}^{3}(134,910 \mathrm{Btu} / \mathrm{bb1})(8.5 \%$ reduction $)$. If the CCC were to replace the pipestill heater in even one $0.09-\mathrm{m}^{3} / \mathrm{sec}(50,000-$ bbl/day) refinery, the displacement of natural gas could be $0.15 \times 10^{6} \mathrm{~m}^{3}$ $\left(5.2 \times 10^{6} \mathrm{ft}^{3}\right)$ per day. The thermal rating of such a unit would be about $82 \mathrm{MW}$ and would likely generate over one-half the refinery's entire electrical demand. Out of approximately 259 refineries in the 


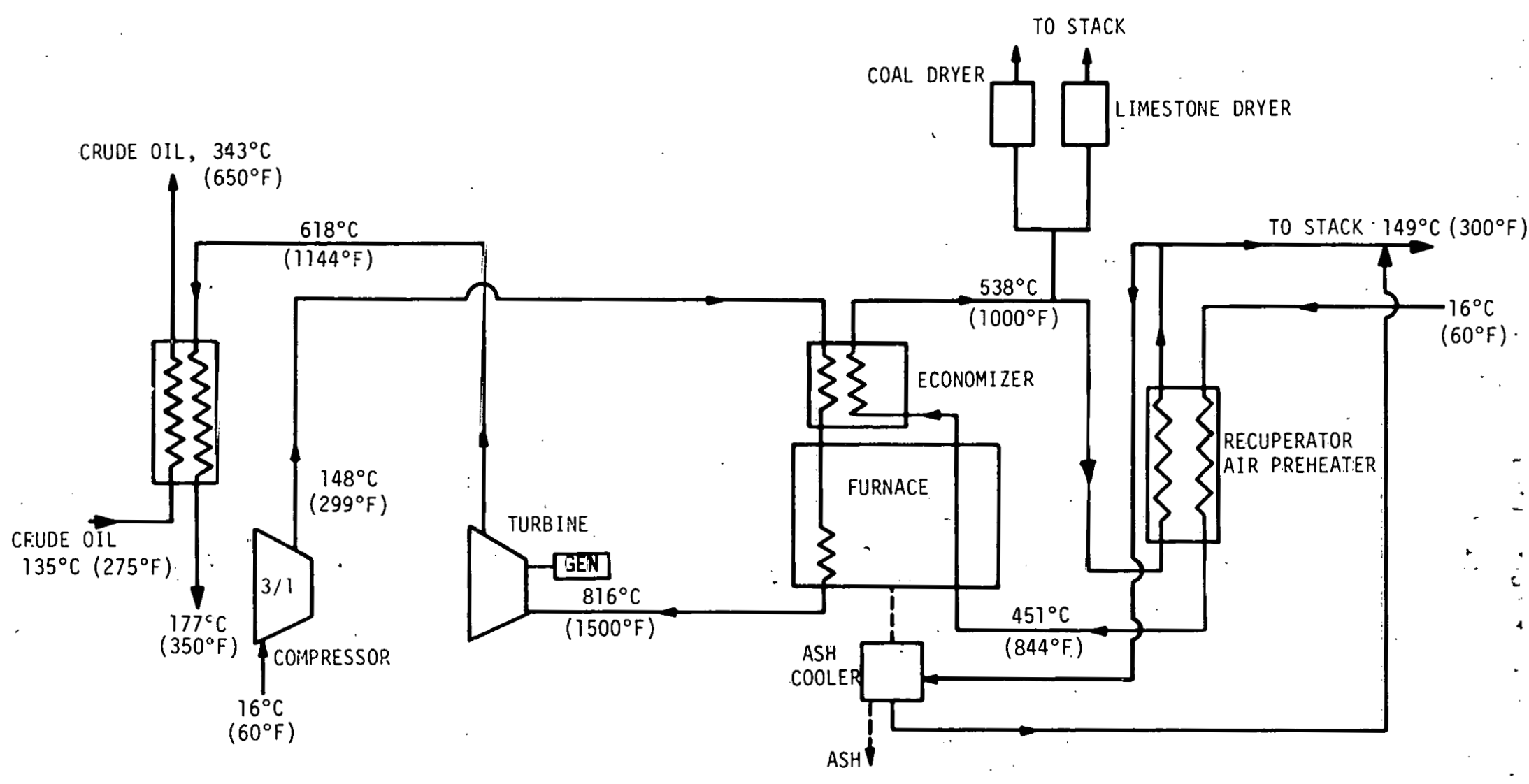

- Fig. 5.8. CCC cogeneration system for crude-oil heating prior to distilling at atmospheric pressure. 
United States, about 71 have capacities averaging $0.09 \mathrm{~m}^{3} / \mathrm{sec}(50,000$ $\mathrm{bb} 1 /$ day). ${ }^{3}$ Refineries having flows of $0.04 \mathrm{~m}^{3} / \mathrm{sec}(20,000 \mathrm{bbl} /$ day $)$ or less numbered 124, with the remaining 64 averaging $0.27 \mathrm{~m}^{3} / \mathrm{sec}(150,000$ bbl/day). ${ }^{3}$

There is an obvious question of capital investment in an air/oil heater. Using a typical pipestill example from Ref. 9, the CCC heat exchanger was found to possibly involve only $40 \%$ more heat transfer surface area. Gas-fired stills depend heavily on radiation heat transfer and, hecause of the low gas velucllies, the convection zone in the still is rather inefficlent and requires a relatively large eurface area. The CCC heat exchanger allows high gas velocities, $>15 \mathrm{~m} / \mathrm{sec}(>50 \mathrm{ft} / \mathrm{sec})$, which lower the surface area requirements. Becausc the syslell electrical output is not critical in this case, the increase in pressure drop can be tolerated. In fact, the higher system $\Delta \mathrm{P} / \mathrm{P}$ would illcituse the gas temperature available to the oil heater, further reducing the surface area requirements. The heat exchanger surface in the fluidizedbed furnace itself is not included in this comparison, but the electrical production would likely justify its cost.

\subsubsection{Vaeuum-dislllilng unit oil heater. A second stage of pro-} cessing, carried out under vacuum to keep temperatiures as low do possible and lu avold undue cracking of products, 1s used where the crudc oil is to be reduced to a low percentage of bottoms (see Fig. 5.9). Uverhead products include heavy lubricating fractions, or heavy cracking stock, in addition to the products taken overhead from a single-stage diotillation unit. The residuum is a viscous pitch used for fuel oil bilending; occasionally, it is a very high melting point asphalt.

Increasingly, vacuum distillation of crude oil is utilized as a means to produce a low-sulfur fuel oil pool in a refinery. Processes to degulfurize vacuum gas oils are available and proven commercially. Processes to desulfurize residues are much more complex and more expensive to install and operate, as well as being somewhat limited in application because of metal contamination of catalysts, for example. The vacuum gas oils are therefore desulfurized and back blended with the vacuum bottoms to achieve a low-sulfur heavy fuel oil pool. In a typical refinery, the flow through the vacuum column is typically 35 to $50 \%$ 


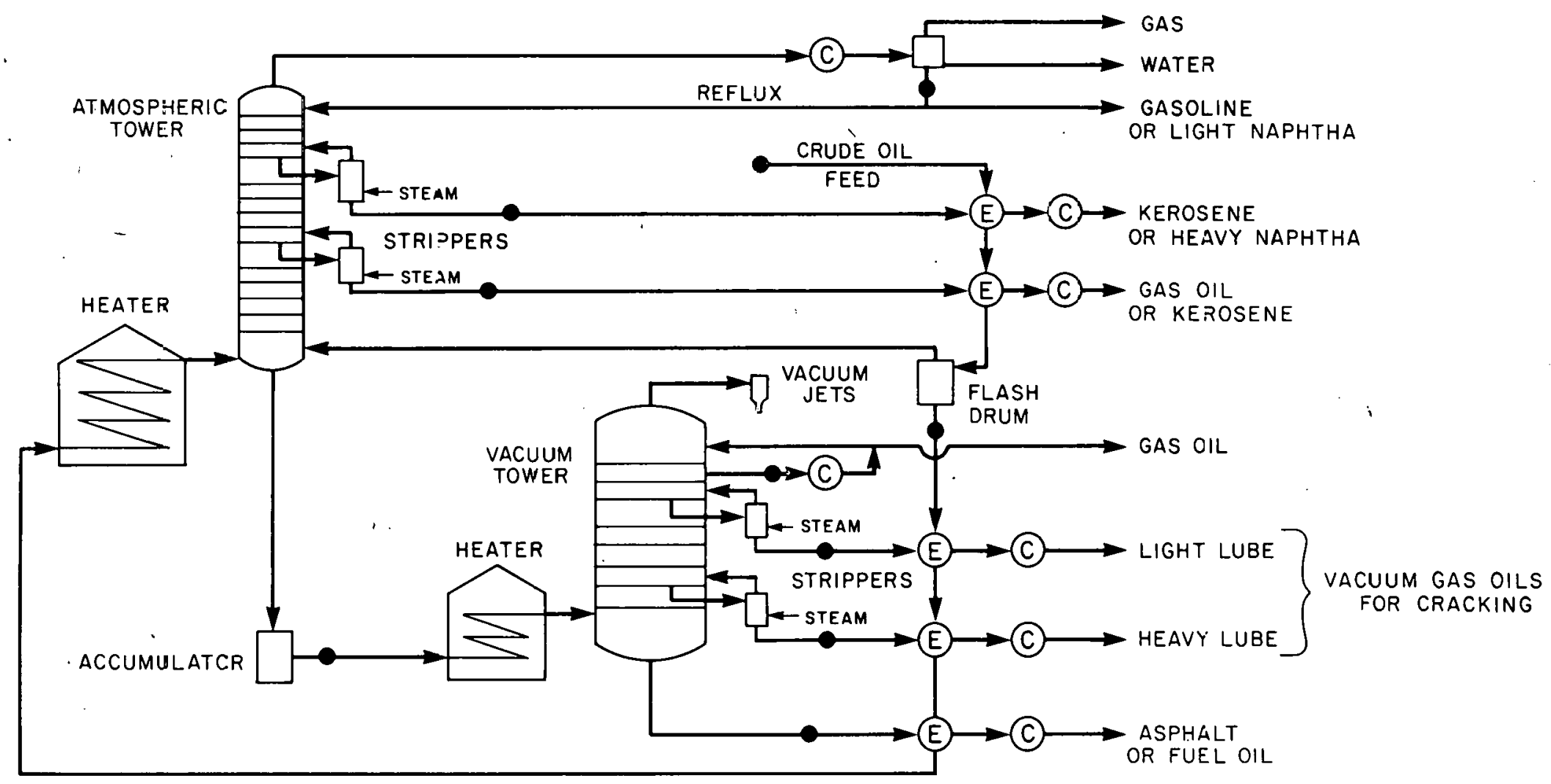

- PUMP

(C) CONDENSER OR CDOLER

(E) EXCHANGER

Fig. 5.9. Vacuum distilling unit in relation to atmospheric column (Ref. 6). 
of the charge to the atmospheric column. ${ }^{7,10}$ Reduced crude residual from the atmospheric unit makes up most of the vacuum distiller charge. The charge to the vacuum column heater enters at 316 to $343^{\circ} \mathrm{C}(600$ to $650^{\circ} \mathrm{F}$ ), with a terminal temperature of 399 to $427^{\circ} \mathrm{C}\left(750\right.$ to $\left.800^{\circ} \mathrm{F}\right)$. Steam, $\sim 34.3$ to $48.6 \mathrm{~kg} / \mathrm{m}^{3}$ (12 to $\left.171 \mathrm{~b} / \mathrm{bbl}\right),{ }^{3,7}$ is also required at 232 to $260^{\circ} \mathrm{C}\left(450\right.$ to $\left.500^{\circ} \mathrm{F}\right)$. Because the gas temperature leaving the reduced crude heater will be quite hot, this steam will probably be generated in a waste-heat boiler. Electrical loads for the unit vary from 1.26 to $3.15 \mathrm{kWhr} / \mathrm{m}^{3}$ ( 0.2 to $0.5 \mathrm{kWhr} / \mathrm{bbl}$ ) in the literature. ${ }^{3,6,7}$ Again, this power demand is small enough that surplus power will be produced. The high-temperature heat requirements suggest that a low-pressure ratio system be employed. The system that was formulated is depicted in Fig. 5.10, and data are listed in Table 5.9. For a $0.09-\mathrm{m}^{3} / \mathrm{sec}(50,000-$ $\mathrm{bbl/day)}$ refinery in which half the volume flow went to the vacuum unit,

Table 5.9. System parameters per cubic meter (barre1) of reduced crude oil input

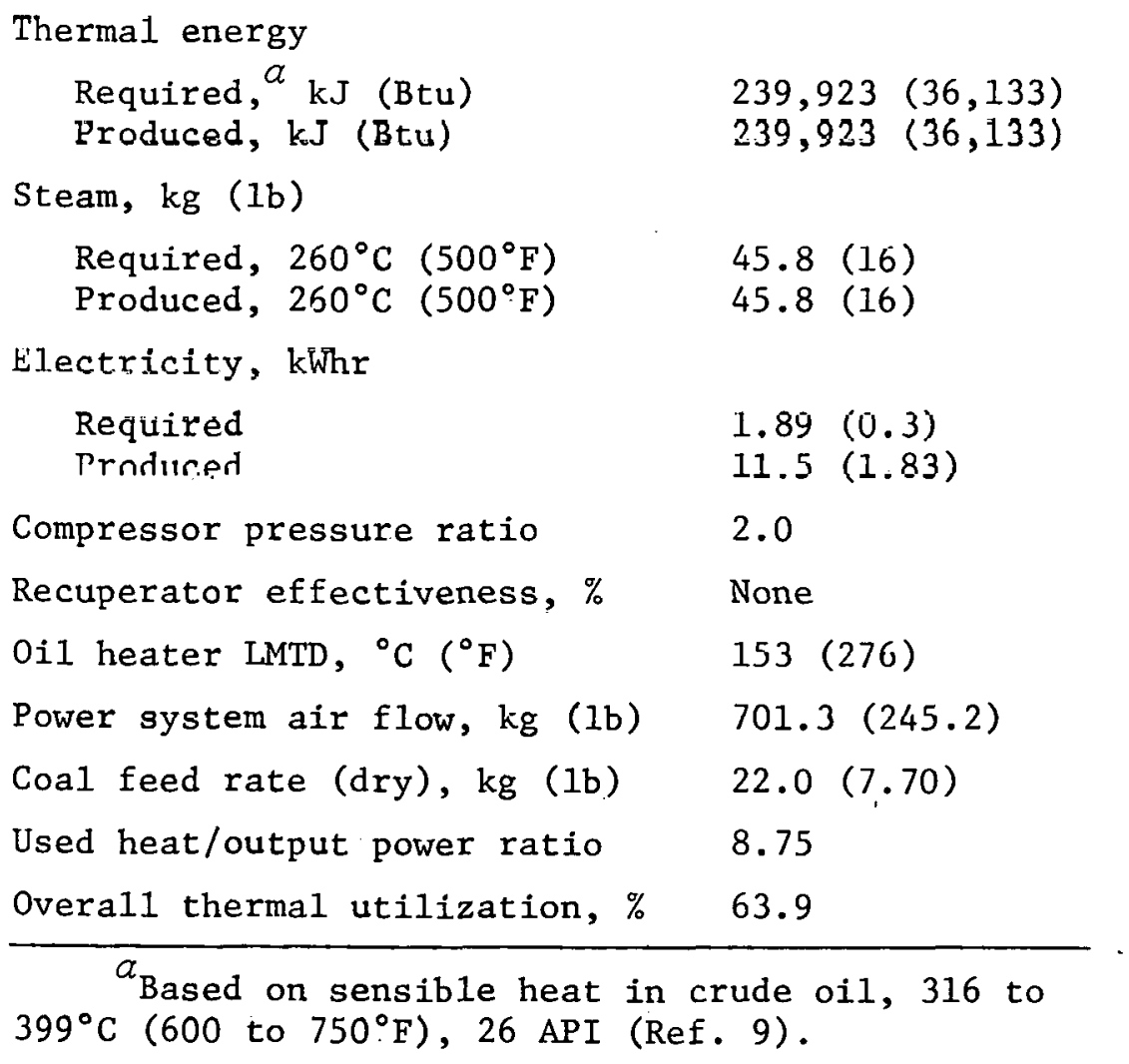


ORNL-DWG 78-3283

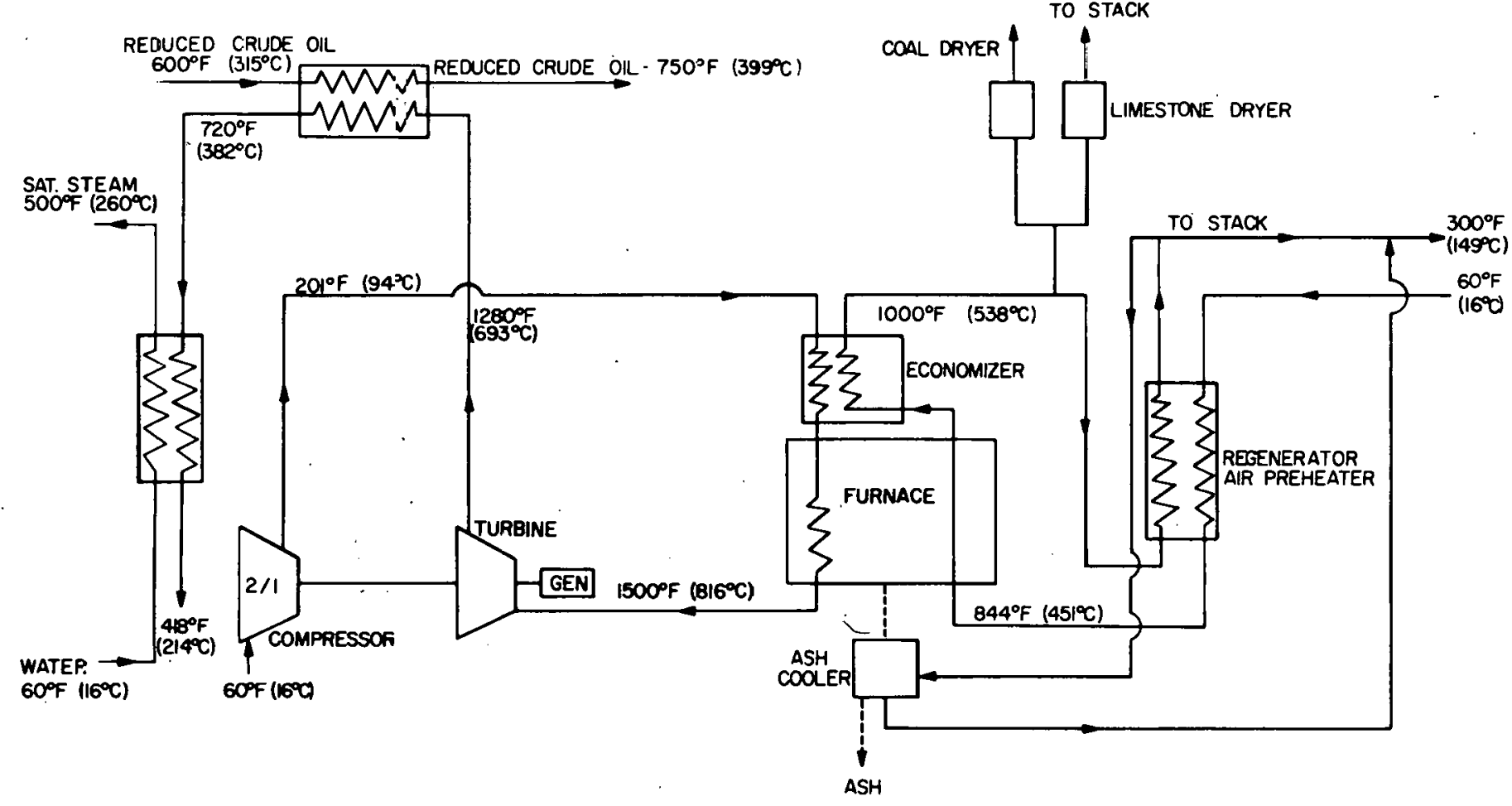

Fig. 5.10. CCC cogeneration system for crude-oil heating prior to vacuum distilling. 
a $29-M W(t)$ CCC unit would be sufficient. The refining industry has been experimenting with the concept of replacing plpestills with fluidizedbed direct oil heaters, indicating a real interest in converting to coal.

\section{2 .4 Food industries}

No one food processing industry is representative of the entire SIC 20 category. Two industries, meat packing and soybean processing, were chosen primarily because they exhibit a definite dependence on electricity and require some heat at over $177^{\circ} \mathrm{C}\left(350^{\circ} \mathrm{F}\right)$.

5.2.4.1 Soybean meal, flour, oil. The specific energy required per pound of soybeans is less than many other food industries, but the total energy consumption per year is among the highest. The plant from which the data in Section 4.3.6.3 were presented apparently lacked the capability to generate either steam or electricity. According to Ref. 11 , at least some plants do generate steam, but none generate electricity in-house. The system devised to meet the needs of a soybean plant is illustrated in Fig. 5.11, and the descriptive data are given in Table 5.10. The specific energy requirement of the soybean plant would be $2400 \mathrm{~kJ} / \mathrm{kg}(1035 \mathrm{Btu} / \mathrm{lb})$. About 119 soybean processing plants were reported to exist in $1973,{ }^{11}$ ranging in capacity from 45 to 3268 metric tons ( 50 to 3600 tons) per day. The plants generally use their capacity consistently. A 908-metric ton (1000-ton) per day plant would require a CCC unit rated at $25 \mathrm{MW}(\mathrm{t})$. Coal is reported to represent $\sim 25 \%$ of the purchased fuels in Ref. 11, indicating that there is no interface problem with coal utilization.

5.2.4.2. Meat packing/processing. An integrated meat packing and meat processing plant displays a rather high electrical demand. The best data available were for hog slaughtering and pork processing. Reportedly, there is no "typical" plant in the meat packing business, but there exists at least one integrated plant locally. Approximately $0.51 \mathrm{~kg}$ of pork is available per $\mathrm{kg}$ of live hog. ${ }^{3}$ This pork may be used in ils raw state or may be converted to other products. This analysis assumes that all of the $0.51 \mathrm{~kg} / \mathrm{kg}$ undergoes further processing. 


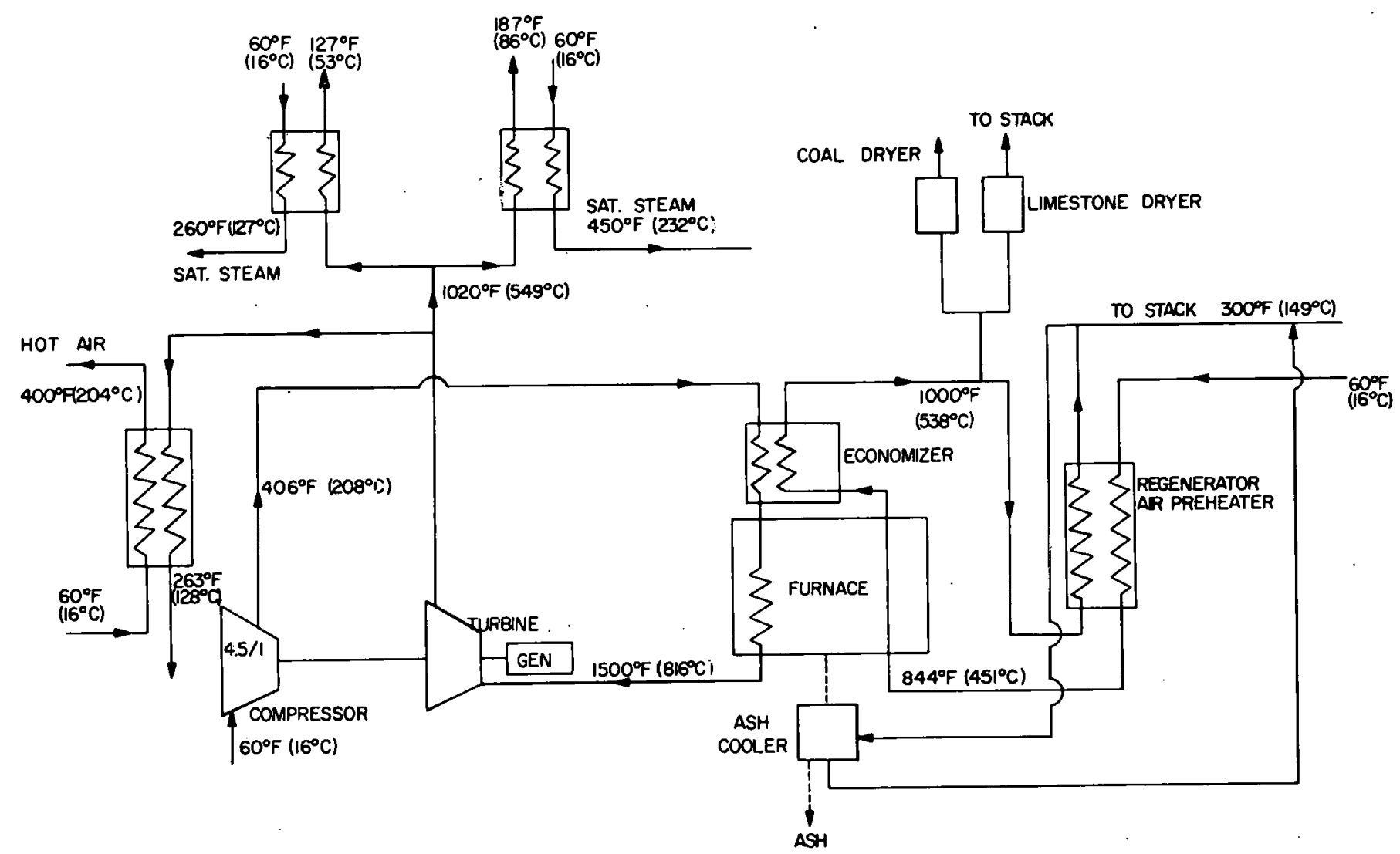

Fig. 5.11. CCC cogeneration system for a soybean meal, flour, and oil plant. 
Table 5.10. System parameters per metric ton (ton) of soybeans cleaned

\begin{tabular}{|c|c|}
\hline \multicolumn{2}{|l|}{ Steam, kg (1b) } \\
\hline Required, $\begin{array}{ll}232^{\circ} \mathrm{C} & \left(450^{\circ} \mathrm{F}\right) \\
127^{\circ} \mathrm{C} & \left(260^{\circ} \mathrm{F}\right)\end{array}$ & $\begin{array}{ll}300 & (600.4) \\
123 & (245.5)\end{array}$ \\
\hline Produced & Al1 \\
\hline \multicolumn{2}{|l|}{ Direct heat } \\
\hline $\begin{array}{l}\text { Required, } 177^{\circ} \mathrm{C}\left(350^{\circ} \mathrm{F}\right), \mathrm{kJ} \text { (Btu) } \\
\text { Produced, } 16 \text { to } 204^{\circ} \mathrm{C} \\
\left(60 \text { to } 400^{\circ} \mathrm{F}\right) \text { air, } \mathrm{kJ}(1 \mathrm{~b}) \\
\text { (sensible heat) }\end{array}$ & $\begin{array}{l}245,920(212, \\
2,993 \quad(2,580)\end{array}$ \\
\hline \multicolumn{2}{|l|}{ Electricity, kWhr } \\
\hline $\begin{array}{l}\text { Required } \\
\text { Produced }\end{array}$ & $\begin{array}{l}80.7(73.2) \\
90.4(82.0)\end{array}$ \\
\hline Compressor pressure ratió & 4.5 \\
\hline Recuperator effectiveness & None \\
\hline Power system air flow, $\mathrm{kg}$ (1b) & $3,126(6,252)$ \\
\hline Coal feed ratio $(\mathrm{dry}), \mathrm{kg}$ (1b) & $84(167.0)$ \\
\hline Used heat/power ratio & 4.69 \\
\hline 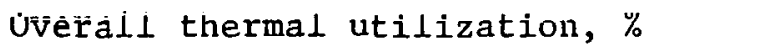 & 76.9 \\
\hline
\end{tabular}

The pertinent datu for the formulated system, Fig. 5.12, are listed in Table 5.11. The polishing and singeing is conventionally accomplished with a gas flame, but the substitution of hot air at $568^{\circ} \mathrm{C}\left(1055^{\circ} \mathrm{F}\right)$ should be more than adequate. The energy required to convert 1 lb of hog on-the-hoof to hot dogs is $\sim 8700 \mathrm{~kJ} / \mathrm{kg}(3745 \mathrm{Btu})$. There are 2991 hog slaughtering facilities in the United States, many of which are involved in meat processing. ${ }^{3}$ A typical plant can handle 1400 hogs per day, which would be equivalent to 153 metric tons ( 168 tons) per day. The required CCC unit size would be about $16 \mathrm{MW}(t)$. Coal was reportedly once an important fuel in the industry; ${ }^{11}$ thus, there should be little problem with its use.

The plants presented in Section 5 were generally of average size in the industry. A more complete listing of size distribution is provided in Table 5.12, with the data primarily from Ref. 3. 


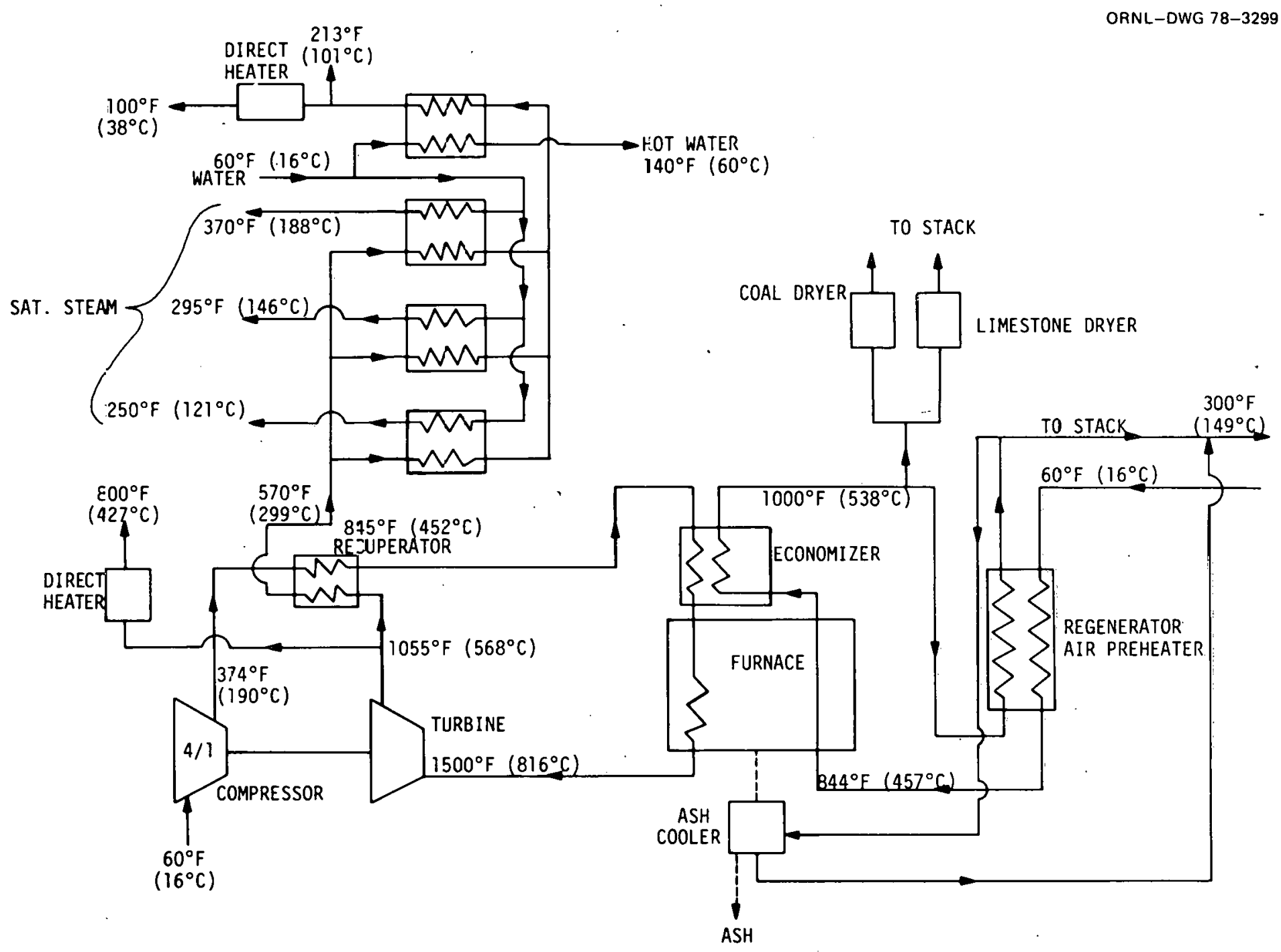

Fig. 5.12. CCC cogeneration system for hog slaughtering and pork processing. 
Table 5.11. System parameters per metric ton (ton) of hog slaughtered $a$

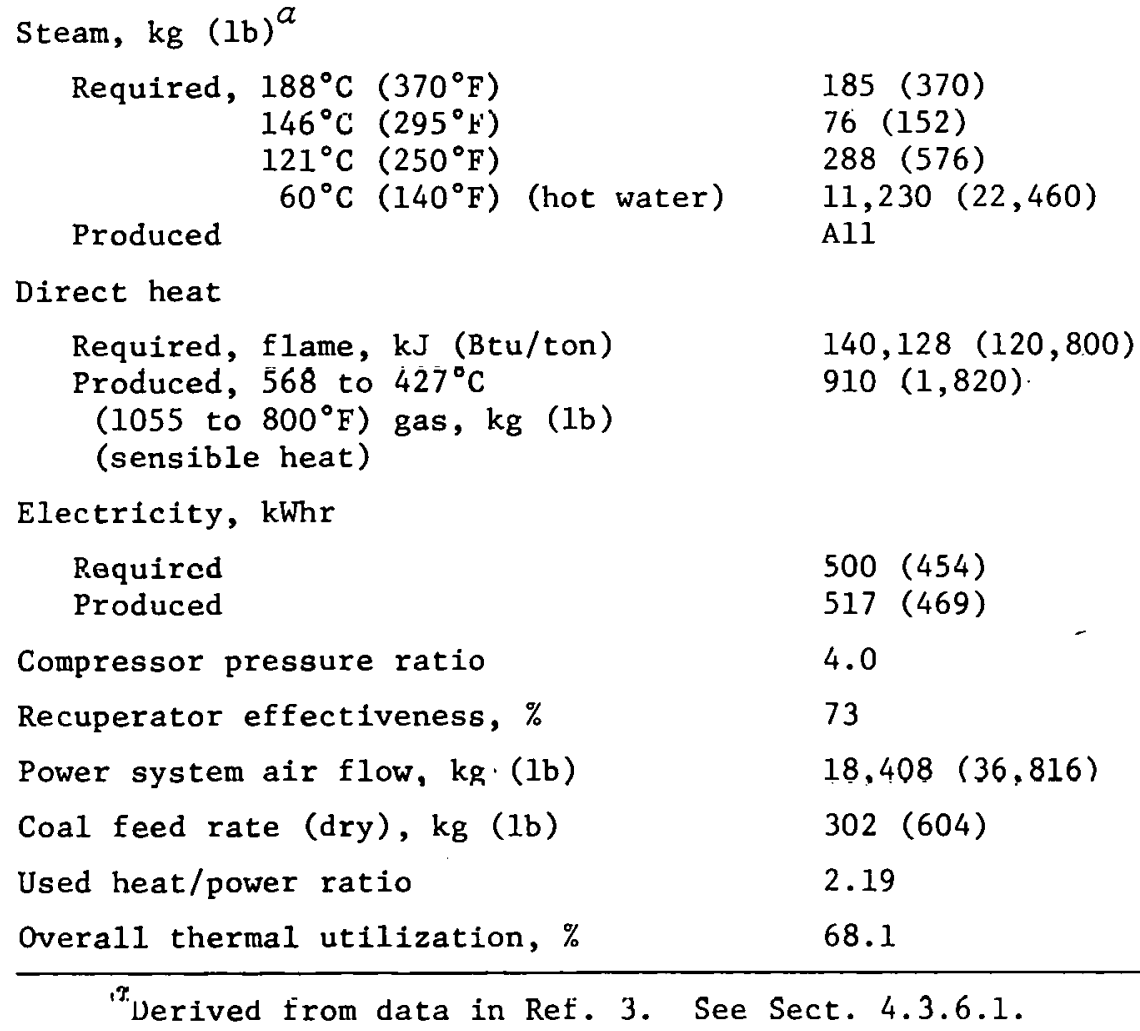

Table 5.12. Sise distributiun of planta given preliminary analysis $a$

\begin{tabular}{|c|c|c|c|}
\hline \multirow[t]{2}{*}{ Industry } & \multicolumn{3}{|c|}{$\begin{array}{c}\text { Numbor of planto in } \\
\text { unit size range } \\
{[M W(L)]}\end{array}$} \\
\hline & $<20$ & $20-100$ & $>100$ \\
\hline HDPE & 8 & 7 & 0 \\
\hline SDR & 4 & 8 & 2 \\
\hline Chlorine/caustic & 2 & 19 & 47 \\
\hline Soybean & 26 & 83 & 0 \\
\hline Meat packing & $936^{D}$ & 55 & 0 \\
\hline Atmospheric distiller & 163 & 96 & 64 \\
\hline Vacuum distiller & 174 & 85 & 0 \\
\hline Total & 1313 & 353 & 113 \\
\hline
\end{tabular}

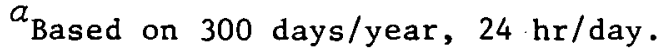

$b_{\text {About }} 830$ are $<1.5 \mathrm{MW}(t)$. 


\section{References}

1. Babcock and Wilcox Company, Summary Evaluation of Atmospheric Pressure Fluidized Bed Combustion Applied to Electric Utility Large Steam Generators: Appendices, EPRI FP-308 (October 1976).

2. A. P. Fraas et al., Use of Coal and Coal-Derived Fuels in Total Energy Systems for MIUS Applications, Vol. II, ORNL/HUD/MIUS-28, Oak Ridge National Laboratory, 1976.

3. Survey of the Applications of Solar Thermal Energy Systems to Industrial Process Heating, Vol. II - Industrial Process Heat Survey, TID 27348/2, Battelle Laboratories (January 1977).

4. International Research and Technology Corporation, Industrial Energy Study of the Industrial Chemicals Group, IRT-342-R (PB-236322). (August 1974).

5. Federa1. Energy Administration, The Data Base - The Potential for Energy Conservation in Nine Selected Industries, Voz. 8, Selected Paper Products, Conservation Paper No. 16, Office of Industrial Prógrams, 1975.

6. Federa1. Energy Administration, The Data Base - The Potential for Energy Conservation in Nine Selected Industries, Vol. 2, Petroleum Refining, Conservation Paper No. 10, Office of Industrial Programs, 1975.

7. V. O. Haynes, Energy Use in Petroleum Refineries, ORNL/TM-5433, Oak Ridge National Laboratory, 1976.

8. R. H. Perry et al., Perry's Chemical Engineers Handbook, 4th ed., McGraw-Hil1 Book Company, 1963.

9. W. L. Nelson, Petroleum Refinery Engineering, 3rd ed., McGraw-Hill Book Company, 1949.

10. G. D. Hobson and W. Pohl, eds., Modern Petroleum TechnoZogy, 4th ed., Holsted Press, John Wiley and Sons, 1973.

11. Development Planning and Research Associates, Industrial Energy Study of Selected Food Industries, FEA-EI-1652 (PB-237316) (July 1974). 


\section{CONCEPTUAL DESIGN OF AFBC GAS-TURBINE COGENERATION SYSTEMS FOR INDUSTRIAL APPLICATIONS}

\subsection{Combustor Design}

The primary consideration in the design of atmospheric fluidizedbed combustor (AFBC) gas-turbine cogeneration systems is the design of the fluidized-bed combustor in unit sizes up to $20^{\circ} \mathrm{MW}(\mathrm{e})$. The thermal rating corresponding to this power output is about $90 \mathrm{MW}(\mathrm{t})$, or $0.09 \times$ $10^{6} \mathrm{~kW}\left(307 \times 10^{6} \mathrm{BLu} / \mathrm{hL}\right)$. This $1 \mathrm{~s}$ a rather high heat rating for a single unit and will require a fairly large area for the fluidized bed. The bed area can be minimized by increasing the bed depth. The economical limit for the bed depth for an atmospheric fluidized bed is probably about 1.5 to $1.8 \mathrm{~m}$ ( 5 to $6 \mathrm{ft}$ ) deep because of the fan power requirements.

The layout drawing for one concept of the combustor is shown in Fig. 6.1. In this design, the bed tube bundle is composed of U-tubes that extend across the full width of the bed, with the turbine air inlet and outlet manifolds on the same side of the bed. The combustion pleiium, alı dlstrlbutor p̈late, and tube bundle are designed to be removed as a unit from the side of the combustor by disconnecting the turbine air inlet and outlet pipes and removing bolts from the air plenum flange. In this layuul, the economizer tube bundle is located above the freeboard. The plenum width is decreased in the economizer region to increase the flue-gas velocity through the economizer for improved heat transfer. The combustor is lined with refractory and doca not make use of cooling tubes in the combustor walls,

An alternate layout for the combustor design is shown in Fig. 6.2. Here the economizer is located beside the freeboard to reduce the overall helght of the unit. A solids removal point is located below the economizer for particulates that settle out of the flue gas after they pass downward through the economizer.

The principal parameters for a conceptual design of a 90-MW( $t$ ) combustor are given in Table 6.1. The design is for a closed-cycle gas turbine with a compressor outlet pressure of $1.2 \mathrm{MPa}$ (175 psia). The 


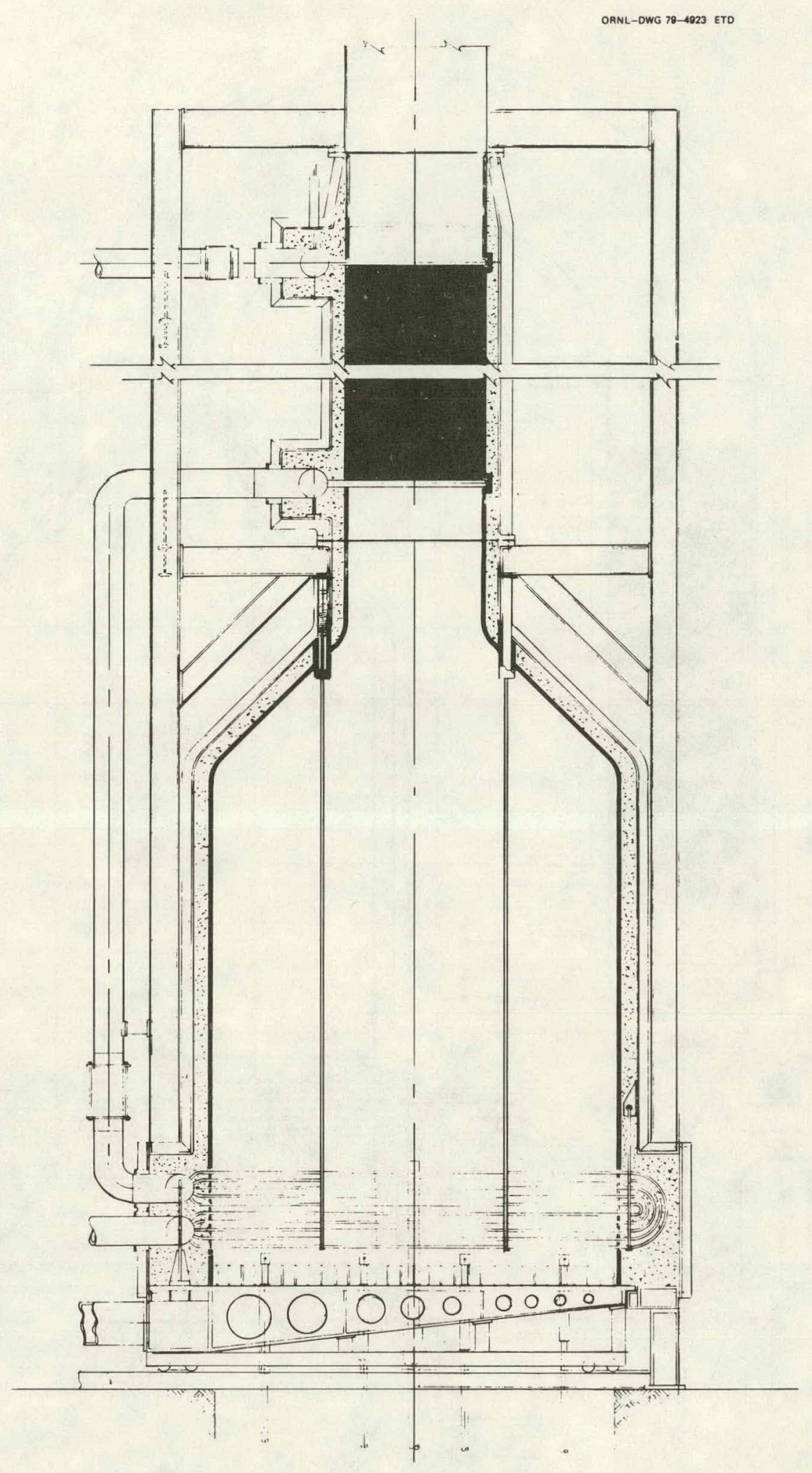

Fig. 6.1. Conceptual layout of a coal-fired fluidized-bed combustor (elevation view). 


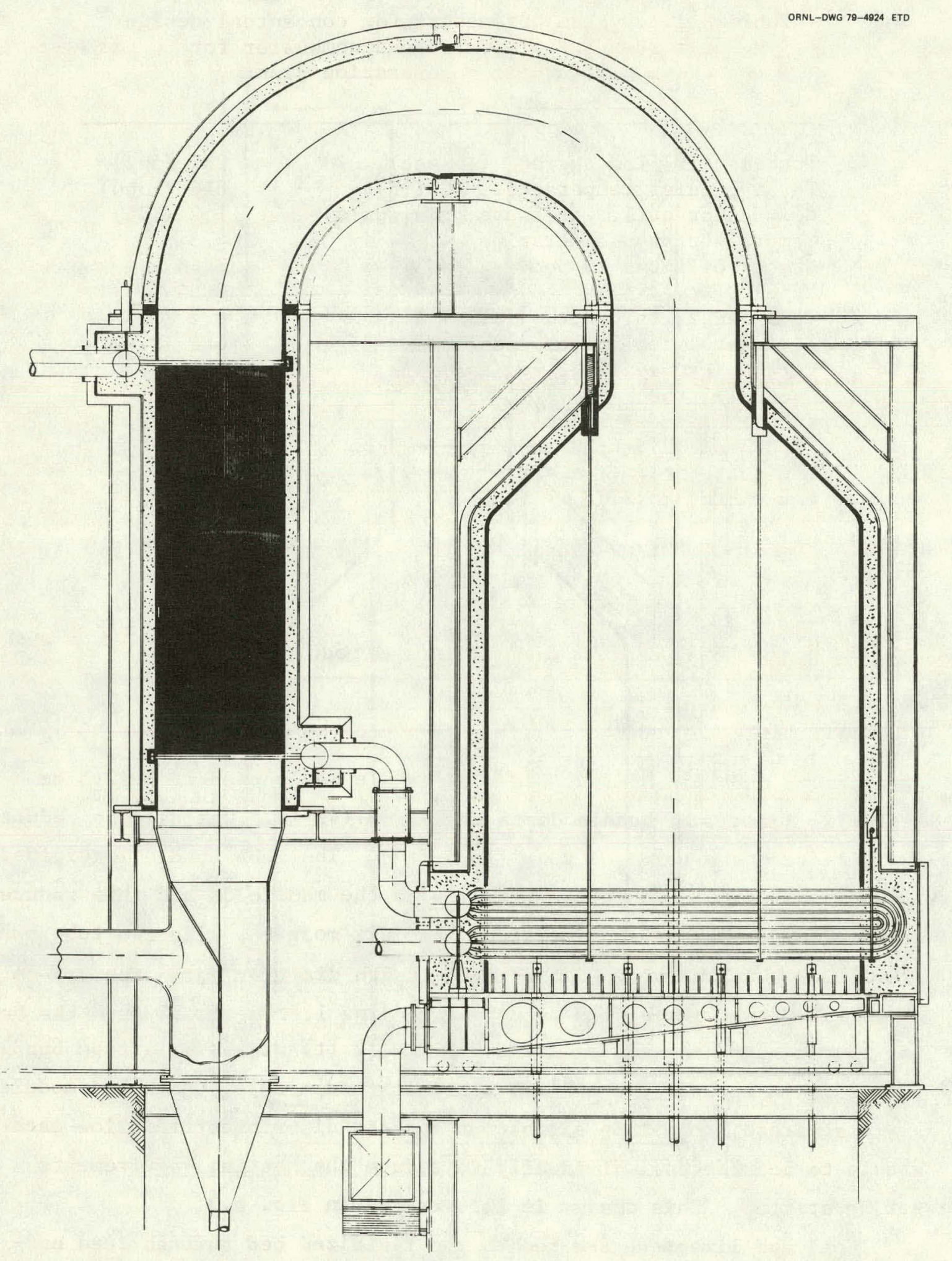

Fig. 6.2. Alternate layout of a coal-fired fluidized-bed combustor (elevation view). 
Table 6.1. System parameters for conceptual design of a 90-MW(t) fluidized-bed combustor for a gas-turbine cogeneration plant

\begin{tabular}{ll} 
Turbine air flow, $\mathrm{kg} / \mathrm{sec}(\mathrm{lb} / \mathrm{sec})$ & $237(522)$ \\
Turbine inlet temperature, ${ }^{\circ} \mathrm{C}\left({ }^{\circ} \mathrm{F}\right)$ & $816(1500)$ \\
Compressor outlet pressure, MPa (psia) & $1.2(175)$ \\
Compressor pressure ratio & 4.3 \\
Number of tubes in bed & 8640 \\
Tube OD, cm (in.) & $2.54(1)$ \\
Tube length in bed, m (ft) & $3.7(12)$ \\
Horizontal tube pitch, cm (in.) & $6.1(2.4)$ \\
Vertical tube pitch, cm (in.) & $5.1(2)$ \\
Number of tube layers in bundle & 24 \\
Tube bundle depth, cm (in.) & $124(49)$ \\
Expanded bed depth, cm (in.) & $147(58)$ \\
Freeboard height, m (ft) & $3.7(12)$ \\
Bed width, m (ft) & $3.7(12)$ \\
Bed module length, m (ft) & $3.7(12)$ \\
Number of bed modules & 6 \\
Total bed area, m ${ }^{2}$ (ft ${ }^{2}$ ) & $80(864)$ \\
Superficial velocity, m/sec (ft/sec) & $1.7(5.5)$ \\
Bed temperature, ${ }^{\circ} \mathrm{C}$ ( $\left.{ }^{\circ} \mathrm{F}\right)$ & $900(1650)$ \\
Number of coal-feed points per bed module & 16 \\
\hline
\end{tabular}

diameter of the tubes in the bed tube bundle was chosen to be $2.5 \mathrm{~cm}$ (1 in.). A bed tube bundle depth of $124 \mathrm{~cm}$ (49 in.) was used to reduce the bed area to a value of $80 \mathrm{~m}^{2}\left(864 \mathrm{ft}^{2}\right)$. The tube bundle is divided into 12 modules to reduce the air flow in the manifolds and thus reduce their diameter. The bed is divided into six modules, with two tube bundles in each bed module. The optimum length diameter ratio for $2.5-\mathrm{cm}$ (1-in.) tubes is given with U-tubes extending $1.82 \mathrm{~m} \mathrm{(6} \mathrm{ft)} \mathrm{into} \mathrm{the} \mathrm{bed;}$ for this design, the bed was made $3.66 \mathrm{~m}$ (12 ft) wide with a tube bundle installed in each of the two sides of each bed module. Each bed module has a separate combustion air plenum and air distributor to allow each module to be started individually to reduce the heating requirements during startup. This design is illustrated in Fig. 6.3.

Coal and limestone are fed to the fluidized bed through feed nozzles located underneath the bed which are supplied by feed lines brought through the distributor plate. There are 16 coal-feed points per bed 


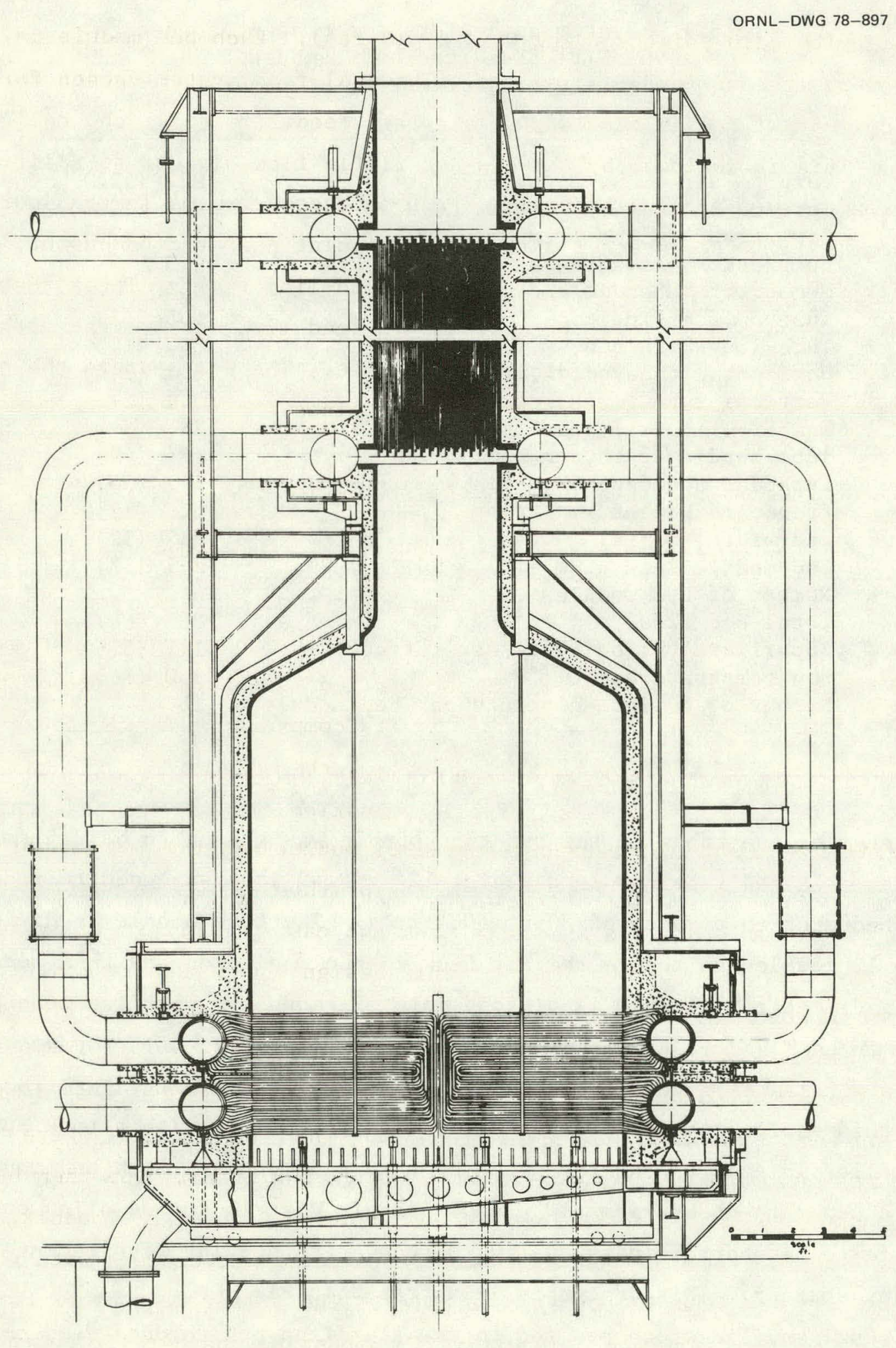

Fig. 6.3. Layout of fluidized-bed combustor with deeper bed and alternate tube configuration. 
module with each point serving $0.84 \mathrm{~m}^{2}\left(9 \mathrm{ft}^{2}\right)$. Each bed module is served by its own coal-feed system. The coal-feed system chosen for the conceptual design consists of a rotary feeder to meter the coal feed. This is followed by a two-stage riffle flow divider to split the coal into four equal streams. Each of these streams is transported pneumatically by compressed air, and at a point near the combustor, each is divided again into four by means of an in-line flow splitter that divides the two-phase flow. Each of the 16 feed lines enters the air plenum and passes through the distributor plate. The coal enters the bed through a feed nozzle on each of the feed lines.

\subsection{Gas-Turbine Selection}

The gas turbine for the fluidized-bed coal-combustion system requires a flow path for the turbine drive air that differs from the majority of the conventional oil-fired gas turbines being built for current use. Because the heat is to be supplied in the fluidized-bed tube bundle, the air must be brought out of the compressor, sent through the combustor tubes, and then routed into the turbine. Most of the gas turbines being built have the oil-fired combustion chamber located inside the turbine casing between the compressor outlet and turbine inlet; the air then flows directly from the compressor through the combustion chamber to the turbine and never exits from the casing until it is exhausted from the turbine. Gas turbines of this design would require modification to provide air ports from the compressor and to the turbine for use with the fluidized-bed combustor.

There are at least two turbine manufacturers offering gas turbines for sale that are designed with external combustion chambers where the air is ducted out of the compressor, through the burner, and then back into the turbine. The AiResearch Manufacturing Company of Phoenix, Arizona, builds a line of gas turbines with external combustors with power output ratings from $500 \mathrm{~kW}(\mathrm{e})$ to $6 \mathrm{MW}(\mathrm{e})$. The Sulzer Company of Switzerland offers gas turbines with external combustion chambers in two power ratings, $4 \mathrm{MW}(\mathrm{e})$ and $20 \mathrm{MW}(\mathrm{e})$. The Sulzer turbines are designed for a pressure ratio of $4.5: 1$, which makes thcm well suited for use with a recuperator in the system. 
Virtually all the gas turbines being produced are designed for open-cycle operation. The turbine cycle is open in the sense that the air to the compressor is drawn from the atmosphere. The compressed air is heated inside the tubes in the fluidized-bed combustor; passed through the turbine, recuperator, and process waste-heat exchanger; and then discharged to the atmosphere. Open-cycle machines designed for an external combustor can be used in open-cycle systems with the fluidized-bed combustor.

For closed-cycle operatiün, mudifylng open-cycle turbines by providing seals designed for a pressure difference of about $0.17 \mathrm{MPa}$ (25 psig) at the compressor inlet and turbine exhaust will be necessary. In some designs, higher strength casings or higher capacity thrust bearings may have to be provided.

The use of a closed-gas cycle turbine offers two advantages.

1. The turbine can follow a varying electrical load on the generator by changing the pressure in the turbine loop and still maintain a constant turbine inlet temperature and full-load cycle efficiency at part load.

2. For a given pressure rac10, the pressure can be higher for the closed cycle, thus resulting in a higher heat transfer capability in the combustor tubes and in the recuperatin. This leads to a reduction in the heat transfer surface area for these components. The increased pressure can also increase the power output of a turbine of a given size. These effects will result in a lower cost for closed-cycle systems.

In applications where the turbine generater is required to follow a widely varying electrical load, two turbines could be controlled by bleeding part of the compressor air to the atmosphere. When the load drops below $50 \%$, one of the turbines would be shut down. For applications where the electrical load varies only slightly, a single turbine generator could be used with each combustor and bypass controls used to follow load changes. In all applications, installing two to four combustor units to provide increased reliability for supplying both heat and electrical power will be most desirable. 


\section{ECONOMIC COMPARISON OF COGENERATION SYSTEM WITH ALTERNATIVES}

The cost of supplying process heat and electricity with a coal combustion cogeneration (CCC) system has been compared with the cost of supplying heat with each of four alternative systems and buying electricity from the utility system. Heat supply systems of four types were included in the comparison: pulverized coal-fired boiler burning low-sulfur coal; pulverized coal-fired boiler burning high-sulfur coal with stack-gas scrubber; AFBC coal-fired boiler; and oil-fired boiler.

A CCC installation with a total thermal rating of $360 \mathrm{MW}(t)$ composed of four units of $90 \mathrm{MW}(t)$ each was used as a basis for the cost comparison. Two comparisons are presented: one in which the CCC is assumed to produce hot process air of the same energy content as the steam produced by the boilers, and a second where the CCC is assumed to be used with a waste-heat boiler. Details of the process, heat condition and cycle configuration are presented in Table 7.1. In both cases, the total fuel input to the CCC is $360 \mathrm{MW}(t)$.

\subsection{Assumptions Used for Cost Estimates}

The major assumptions used for making the cost estimates are given in Table 7.2. The capltal costs for the systems were based on the cost for buying the equipment in 1978. The plant life was assumed to be 20 years, and the capital or fixed charges for the investment were assumed to be $21 \% /$ year, which is considered in the range of satisfactory capital returns for industrial investments.

The fuel prices assumed for the cost estimate are average values reported for early 1978 for eastern Pennsylvania. Fuel prices vary depending on locality but are reported to be similar to those for a number of areas in the midwestern and northeastern states. The price for purchased electricity was assumed to be $3.5 \mathrm{c} / \mathrm{kWhr}$. The prices reported for these same states varied from about 3.2 to $3.8 \mathrm{c} / \mathrm{kWhr}$. The amount of electricity used was based on an assumed plant load factor of $85 \%$ for each case. The cost of fuel and purchased electricity was assumed to increase at a 
Table 7.1. CCC system parameters for economic comparison (four modules)

\begin{tabular}{|c|c|c|}
\hline Parameters & Case I & Case II \\
\hline Steam temperature, ${ }^{\circ} \mathrm{C}\left({ }^{\circ} \mathrm{F}\right)$ & $371(700)^{a}$ & $186(367)$ \\
\hline Steam pressure, $\mathrm{MPa}$ (psig) & $4.48(650)$ & $1.03(150)$ \\
\hline Gas-turbine cycle configuration & Open & Closed \\
\hline Compressor pressure ratio & 4.3 & 6.11 \\
\hline Turbine inlet temperature, ${ }^{\circ} \mathrm{C}\left({ }^{\circ} \mathrm{F}\right)$ & $816(1,500)$ & $816(1,500)$ \\
\hline Steam flow rate, $\mathrm{kg} / \mathrm{sec}(\mathrm{lb} / \mathrm{hr})$ & $75.6(600,000)$ & $72.7(578,000)$ \\
\hline Gas-turbine air flow, $\mathrm{kg} / \mathrm{sec}(1 \mathrm{~b} / \mathrm{sec})$ & $162(358)$ & $132(291)$ \\
\hline Recuperator effectiveness, $\%$ & 54 & 13 \\
\hline Turbine adiabatic efficiency, $\%$ & 85 & 85 \\
\hline Compressor adiabatic efficiency, $\%$ & 85 & 85 \\
\hline System $\Delta \mathrm{P} / \mathrm{P}, \%$ & 10 & 10 \\
\hline Bed temperature, ${ }^{\circ} \mathrm{C}\left({ }^{\circ} \mathrm{F}\right)$ & $900(1,650)$ & $900(1,650)$ \\
\hline $\begin{array}{l}\text { Bed tube heat transfer coefficlent, } \\
\mathrm{W} / \mathrm{m}^{2}-{ }^{\circ} \mathrm{C}\left(\mathrm{Btu} / \mathrm{hr}-\mathrm{ft} \mathrm{t}^{2}-{ }^{\circ} \mathrm{F}\right)\end{array}$ & $284(50)$ & $284(50)$ \\
\hline Power output, MW(e) & 76 & 66 \\
\hline
\end{tabular}

Table 7.2. Assumptions used for cost estimate

1978 dollars for capital investment
$9 \%$ construction interest rate
Three-year construction time
$15 \%$ contingency for coal-fired plants
$10 \%$ contingency for ofl-fired plant
$20 \%$ indirect cost. for engineering and construillun
$21 \%$ annual capitalisatinn rate fur 20 -ycar life
$\$ 25 /$ ton cost for high-sulfur coal
$\$ 33 /$ ton cost for low-sulfur coal
$\$ 6 /$ ton cost for limestone
$\$ 2.20 / 10^{6}$ Bru cost tor fuel oil
$3.5 \mathrm{c} / \mathrm{kWhr}$ cost for purchased electricity
$7 \%$ arinual escalation rate for fuel and electricity
$85 \%$ plant load factor


rate of $7 \%$ /year over the 20 -year plant life as a result of general cost escalation.

\subsection{Coal-Combustion Cogeneration System}

The estimated capital costs for the CCC system installation are shown in Table 7.3. Because a combustor of this type has not yet been built or developed, a cost range was used for the combustor to allow for a greater uncertainty in its estimated cost than for other equipment of a more conventional nature in the system. The combustor cost estimate was based on a conceptual design sized for a nominal rating of $90 \mathrm{MW}(\mathrm{t})$ and the design conditions given in Table 7.1. About twothirds of the system cost is for the heat supply equipment, and about one-third is for the electric power generating equipment.

\subsection{Pulverized Coal-Fired Boilers}

The cost was estimated for conventional pulverized coal-fired boilers with and without stack-gas scrubbers. The cost estimate without scrubbers is given in Table 7.4 and with scrubbers in Table 7.5. The addition of scrubbers is estimated to add about $\$ 10$ million to the overall cost.

The cost estimates for these systems were derived from estimates made in 1977 for Oak Ridge National Laboratory (ORNL) by United Engineers for installations composed of four boilers of a $31.5 \mathrm{~kg} / \mathrm{sec}(250,000$ $1 \mathrm{~b} / \mathrm{hr}$ ) steam capacity each. The costs were adjusted for escalation and for the rated steam capacity of the installation.

\subsection{AFBC Coal-Fired Boilers}

The cost estimate for this system is also derived from estimates made In 1977 for ORNL by United Engineers for a four-boiler installation of $31.5 \mathrm{~kg} / \mathrm{sec}(250,000 \mathrm{lb} / \mathrm{hr})$ each. The cost for four AFBC units of $18.9 \mathrm{~kg} / \mathrm{sec}(150,000 \mathrm{lb} / \mathrm{hr})$ steam at $4.5 \mathrm{MPa}(650 \mathrm{psig})$ and $371^{\circ} \mathrm{C}\left(700^{\circ} \mathrm{F}\right)$ is given in Table 7.6. Because the AFBC boiler is not fully developed, United Engineers did not give a delailed breakdown of the cost of the 
Table 7.3. Capital costs for CCC system [four 90-MW(t) units]

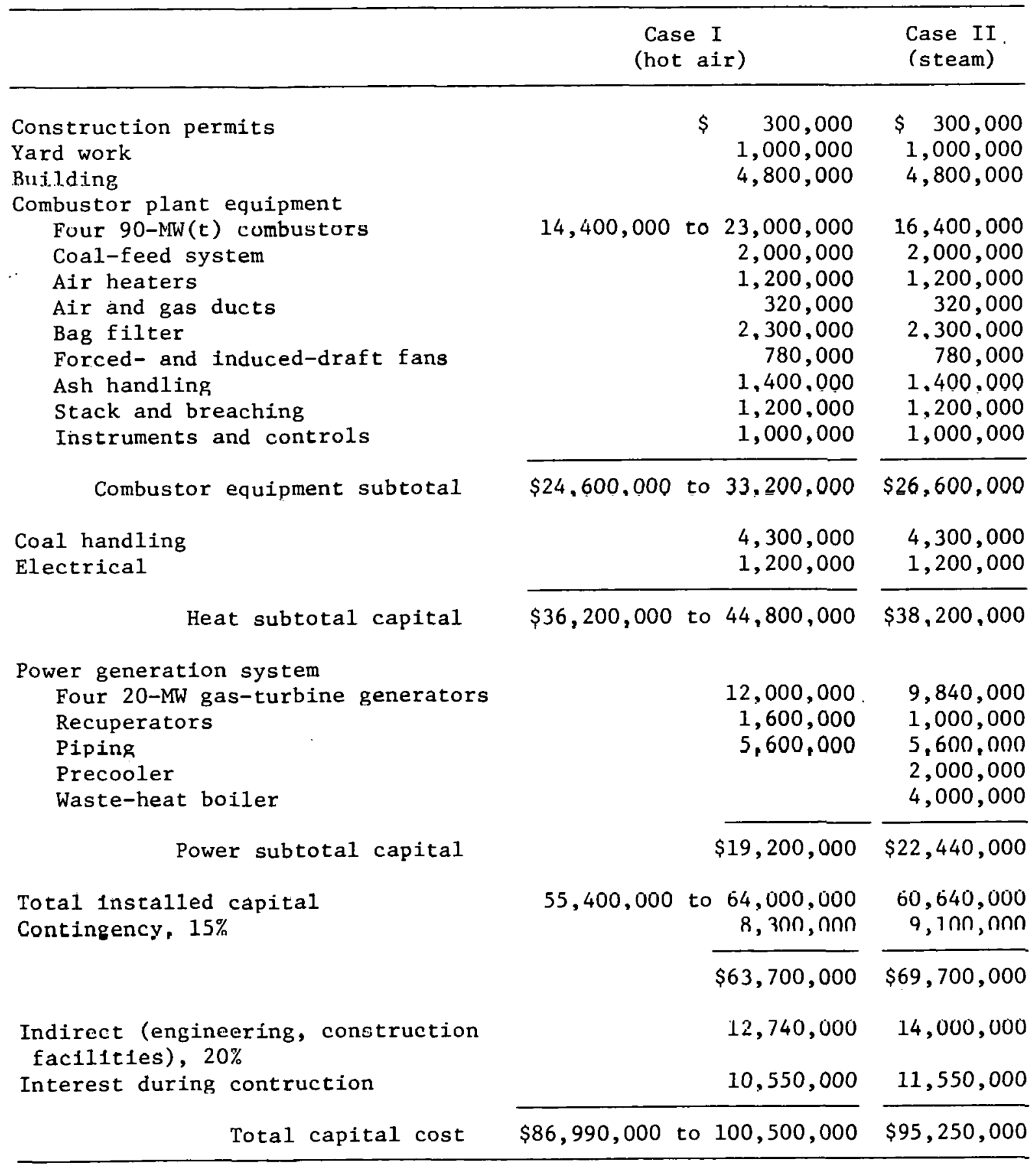


Table 7.4. Capital costs for pulverized coal-fired industrial boiler without scrubbers, $75.6 \mathrm{~kg} / \mathrm{sec}$ $(600,000 \mathrm{lb} / \mathrm{hr}), 4.48 \mathrm{MPa}(650 \mathrm{psig})$, $371^{\circ} \mathrm{C} \cdot\left(700^{\circ} \mathrm{F}\right)$

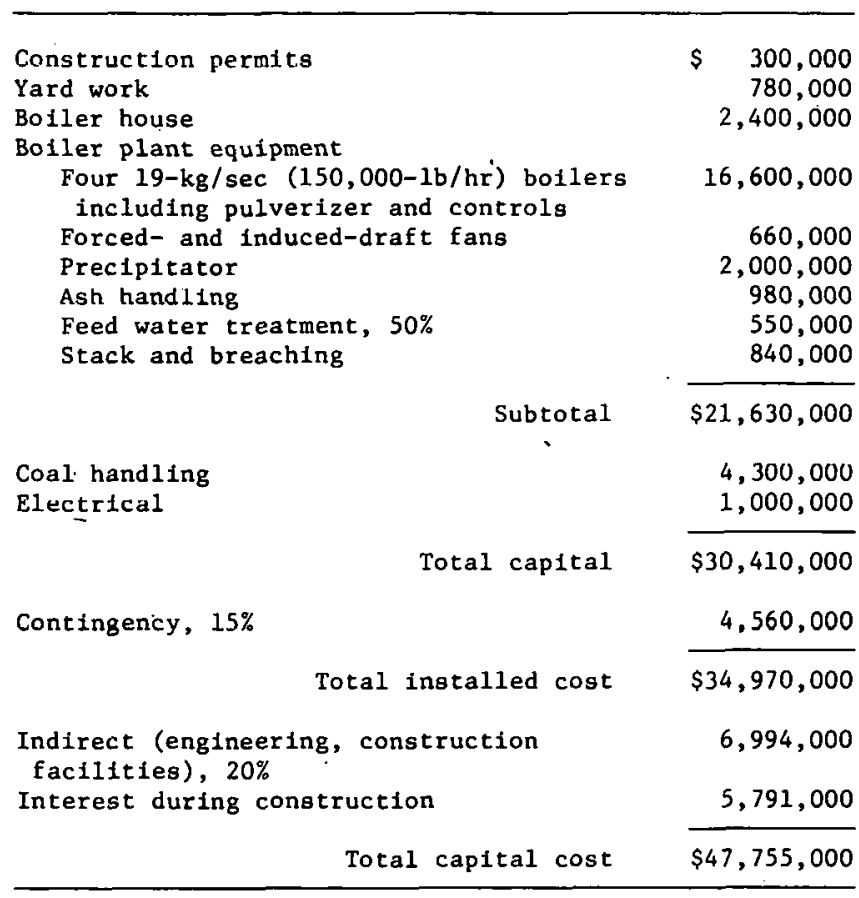

Table 7.5. Capital costs for pulverized coal-fired industrial bollers with scrubbers, $75.6 \mathrm{~kg} / \mathrm{sec}(600,000 \mathrm{lb} / \mathrm{hr})$,

$$
4.48 \mathrm{MPa}(650 \mathrm{psig}), 371^{\circ} \mathrm{C}\left(700^{\circ} \mathrm{F}\right)
$$

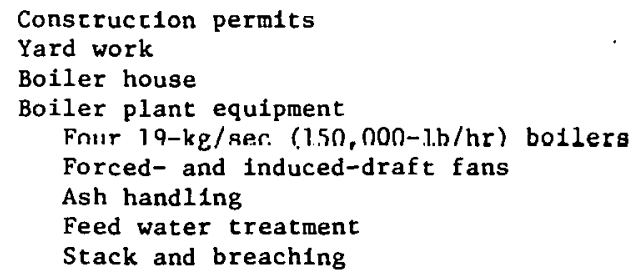

Total boiler equipment

Coal handling

Electrical

Scrubber system (fans, scrubber, and particulate collection reaction tanks)

Total

Cont1ngency, $15 \%$
\$ 300,000

780,000

$2,400,000$

$16,600,000$ 660,000 980,000 550,000 840,000

$\$ 19,630,000$

$4,300,000$

$1,000,000$

$8,300,000$

$\$ 36,710,000$

$5,500,000$

$\$ 1 / 2,210,000$

$8,440,000$ $6,990,000$ 
Table 7.6. Capital cost for atmospheric fluidized-bed industrial boiler, four units, $75.6 \mathrm{~kg} / \mathrm{sec}(600,000 \mathrm{lb} / \mathrm{hr})$ steam, $4.48 \mathrm{MPa}(650 \mathrm{psig}), 371^{\circ} \mathrm{C}\left(700^{\circ} \mathrm{F}\right)$

Construction permits

Yard work

Boiler house

Boiler plant equipment

Coal handling

Electrical

Contingency, $15 \%$
Motal installed cost
Indirect (engineering, construction facilities), $20 \%$
Interest during construction

Tulal capilal cust

$$
\begin{array}{r}
300,000 \\
780,000 \\
2,200,000 \\
20,770,000 \\
4,300,000 \\
840,000
\end{array}
$$

$\$ 29,190,000$

$4,400,000$

$\$ 33,590,000$

$6,790,000$

$5,572,000$

$\$ 45,952,000$

boiler plant equipment. Their estimate was based on information from boiler firms engaged in $A F B C$ boiler development, but, because of the uncertainty in the costs, they preferred to give an overall boiler cost estimate only. The total estimated capital cost is about $\$ 2$ million less than pulverized-coal boilers without scrubbers and about $\$ 12$ million less than the pulverized-coal system with scrubbers.

\subsection{Oil-Fired Package Boiler}

The comparison included the cost of an oil-fired package boiler to supply steam for process heat, and this cost estimate is given in Table 7.7. The boiler cost was based on a unit cost of $\$ 44 / \mathrm{kg}-\mathrm{hr}(\$ 20 / 1 \mathrm{~b}-\mathrm{hr})$ of steam capacity for the total direct cost for this system. A $10 \%$ contingency was included, as well as indirect charges and interest during construction. The capital cost is about one-third of that for the coal-fired boilers, but this difference is more than offset by the 
Table 7.7. Capital costs for oil-fired package boiler

\begin{tabular}{|c|c|c|}
\hline & $\begin{array}{c}\text { Case I } \\
\text { (high pressure) }\end{array}$ & $\begin{array}{c}\text { Case II } \\
\text { (low pressure) }\end{array}$ \\
\hline $\begin{array}{l}\text { Capital cost } \\
\text { Contingency, } 10 \%\end{array}$ & $\begin{array}{r}\$ 12,000,000 \\
1,200,000\end{array}$ & $\begin{array}{r}\$ 11,000,000 \\
1,100,000\end{array}$ \\
\hline Total installed capital & $\$ 13,200,000$ & $\$ 12,100,000$ \\
\hline $\begin{array}{l}\text { Indirect, } 20 \% \\
\text { Interest during construction }\end{array}$ & $\begin{array}{l}2,640,000 \\
1,580,000\end{array}$ & $\begin{array}{l}2,400,000 \\
1,500,000\end{array}$ \\
\hline Total capital cost & $\$ 17,420,000$ & $\$ 1.6,000,000$ \\
\hline
\end{tabular}

higher fuel costs for the oil-fired boiler. This is the only option chosen for comparison with the CCC coupled to a waste-heat boiler.

\subsection{Comparison of Annual Cost}

The annual cost for each of the systems is given in Table 7.8. The annual cost includes the fixed capital charges of $21 \%$ of the capital cost, the cost of fuel and limestone, and the cost of purchased electricity. The cost of fuel, limestone, and electricity includes a multiplying factor of 1.63 to account for $7 \%$ cost escalation per year for 20 years discounted to the present worth. The cost for the CCC system includes a range of uncertainty for the capital cost and a range in the purchased electricity in the amount of $10 \%$ of the system electrical output to allow for the effect of a $10 \%$ decrease in power output for the case where the turbine inlet temperature is assumed to be reduced from 816 to $788^{\circ} \mathrm{C}$ $\left(1500\right.$ to $\left.1450^{\circ} \mathrm{F}\right)$ to ease the materials requirements for the tubes in the fluidized bed.

The greatest factor in the cost comparison is the influence of the cost of purchased electricity. For the electricity cost and load factor used here, the annual costs show that the cost savings realized by inplant electrical generation results in a substantial annual cost savings with the CCC system, despite its considcrably larger capital costs. The 
Table 7.8. Annual cost comparisons

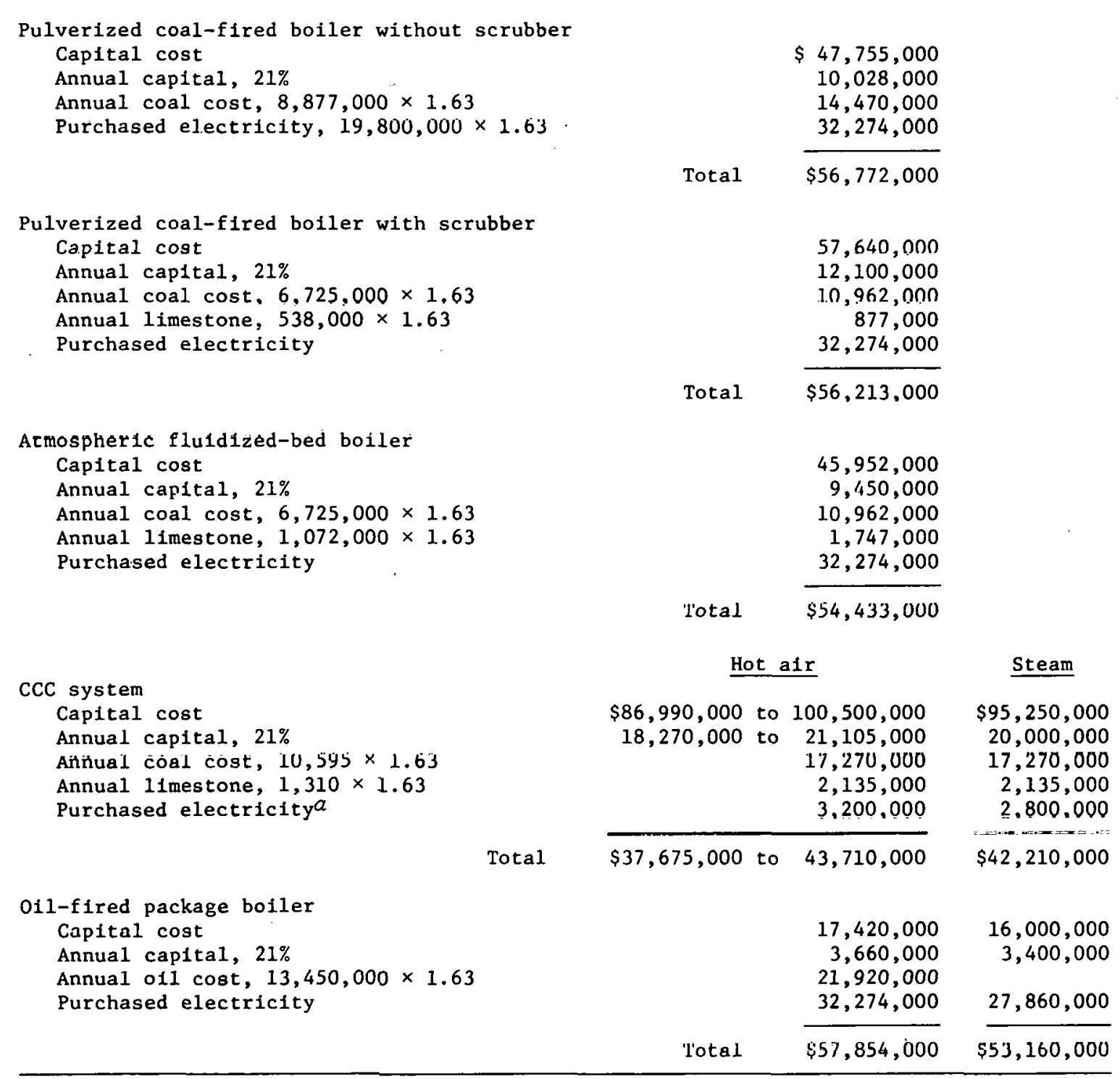

\footnotetext{
$a_{A}$ contingency of $10 \%$ purchased power 1 s assumed and added.
}

other significant effect is the fact that the higher estimated fuel costs for oil results in a slightly higher annual cost for the oil-fired boiler than for any of the alternative coal-fired boilers.

Comparisons of the annual costs for the systems are illustrated in Figs. 7.1 and 7.2. The estimated annual cost savings with the CCC system 
ORNL-DWG 79-4925 ETD

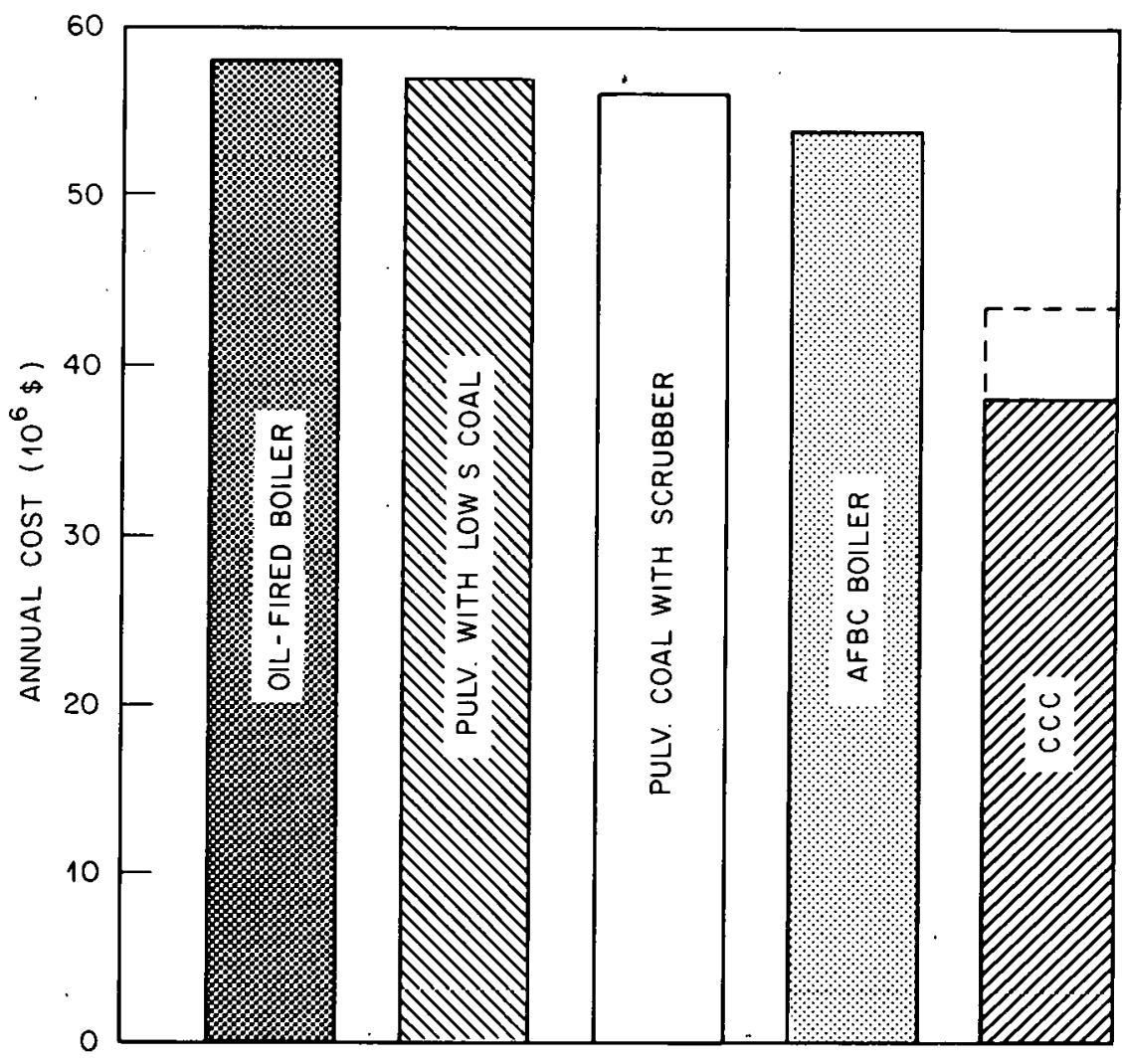

Fig. 7.1. Comparison of the annual cost of the CCC hot air system with alternative systems purchasing electricity.

ranges from 20 to $30 \%$ as compared with the AFBC boiler and 25 to $35 \%$ as compared with the oil-fired package boiler system. Where the oilfired boiler is already installed and fully capitalized, the annual savings would still amount to 20 to $30 \%$.

Furthermore, as indicated by the results of the second case utilizing a waste boiler with the CCC, the addition of the boilers does not detract significantly from the annual cost advantage of the CCC. The cost of the precooler is also relatively low, which means that closing the gas-turbine cycle may result in a net economic advantage due to the reduction in heat-exchanger surface requirements in the furnace and recupcrator that would recult. 
ORNL- DWG $79 \div 4926$ ETD

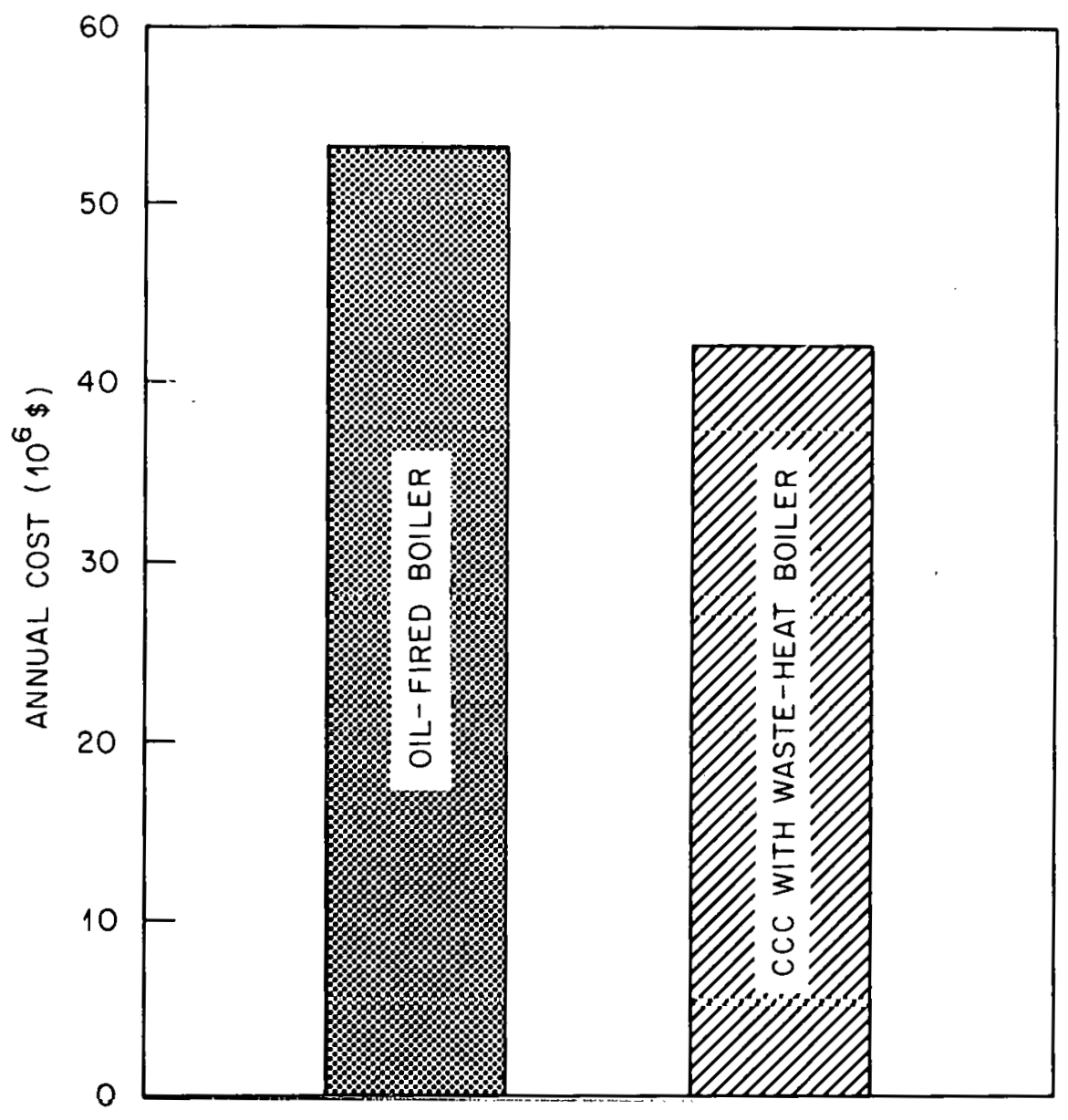

Fig. 7.2. Comparison of the annual cost of the CCC system coupled to waste-heat boiler with alternate system and purchased electricity. 


\section{CONCLUDING REMARKS AND RECOMMENDATIONS}

This report was intended to include enough detailed data to support the conclusions, allow readers to draw their own conclusions, and avoid the over-generalizing so prevalant in energy surveys. Significant findings in regard to the objectives of the study (see "Introduction," Chapter 2) are summarized in the following sections.

\subsection{Theoretical Potential Market}

The industrial energy requirements primarily determine the applicability of the system, specifically the process heat and electricity. Thus the potential market should be discussed in terms of energy and not just the number of installations. Based on extrapolation, from the six greatest energy-consuming industries (from Table 3.8), the industrial process heat energy consumption was estimated as $15,750 \times 10^{12} \mathrm{~kJ}$ $\left(15,000 \times 10^{12} \mathrm{Btu}\right)(1974), \sim 50 \%$ of the total industrial burden on primarily energy sources (fue1s) and $219 \%$ of the total United States burden on primary fuels. This "thermal market" for the fluidized-bed gas-turbine is substantial, especially in view of the recent thrust toward increasing the use of coal.

\subsection{Impact on 011 and Natural Gas Consumption}

The reduction in use of natural gas and oil is of paramount importance, and the ability to use more available fuels is a primary factor that will determine the desirability of any cogeneration system. Typically 90 to $92 \%$ of the oil and gas purchased by industry (excluding feedstocks) is used for heat. Therefore, the oil and gas presently consumed for process heat which could theoretically be displaced by coal can be identified.

The values are listed in Table 8.1. A tremendous conservation potential for the nation's gas resources exists here and a substantial potential savings for oil. 
Table 8.1. Estimated annual oil and gas consumption for industrial process heating

\begin{tabular}{|c|c|}
\hline Fuel & Consumption \\
\hline $\begin{array}{l}\text { Oil, } 10^{6} \mathrm{~m}^{3}\left(10^{6} \mathrm{bbl}\right)^{a} \\
\text { Oil, } 10^{12} \mathrm{~kJ}\left(10^{12} \mathrm{Btu}\right) \\
\text { Natural gas, } 10^{9} \mathrm{~m}^{3}\left(10^{9} \mathrm{ft}^{3}\right)^{b} \\
\text { Natural gas, } 10^{12} \mathrm{~kJ}\left(10^{12} \mathrm{Btu}\right)\end{array}$ & $\begin{array}{l}36-83(225-523) \\
1452-3264(1376-3094) \\
170-250(5937-8703) \\
6482-9466(6145-8973)\end{array}$ \\
\hline $\begin{array}{l}{ }^{a} \text { About } 53 \% \text { of industrial oil } \\
\text { U.3. ull consumption. } \\
b_{\text {About }} 86 \% \text { of industrial gas }\end{array}$ & onsumption, $9 \%$ of \\
\hline
\end{tabular}

\subsection{Thermodynamic Feasibility}

The capability of the CCC to supply useful thermal process energy at temperatures up to $816^{\circ} \mathrm{C}\left(1500^{\circ} \mathrm{F}\right)$ while producing electricity enhances its thermodynamic feasibility in satisfying process heat demands in industry. The high-temperature heating capacity of the CCC is somewhat unique among cogeneration systems. From data on the temperature spectrum of process heating, 61 to $64 \%$ of the energy is required at temperatures less than $816^{\circ} \mathrm{C}\left(1500^{\circ} \mathrm{F}\right)$. Thus the thermodynamically feasible potential for fucl conversion appears as the values in Table 8.2.

\subsection{Other Findings}

Specific case studies were investigated on a preliminary basis to gain some insight as to the actual fucl efficiency likely with the system. Practical problems were discussed where cufficicnt information existed. The market for about 1000 CCC units was identified on investigation of only eight specific industries, including representatives from petroleum refining, food processing, and chemicals. Typical fuel efficiencies were on the order of $70 \%$. However, the value of in-house electric generation alone may prove to be an equally significant advantage for industry. 
The advantages of in-house power generation with fluidized-bed gasturbine systems will be increased if electrical energy becomes a more prominent and effective method of producing high-temperature energy for such processes as ferrous metal heating, metal reheating for hot forming (e.g., forging), and glass melting. Furthermore, in a preliminary analysis, the economics appeared favorable for the CCC over noncogeneration systems.

\subsection{Recommendations}

This survey has been developed with the premise that coal will become the preferential source of environmentally acceptable industrial energy. Fluidized-bed combustors, now in the development stage, conceptually satisfy this premise. The theoretical future market disclosed by this survey is a clear mandate to proceed with concentrated engineering and development programs designed to realize the full technological potential of CCC systems. Technological barriers to implementation of fluidized beds have recently been summarized in Ref. 1 .

A recent study by the Thermo Electron Corporation ${ }^{2}$ estimated that a very high percentage of industry would invest in cogeneration systems, provided a reasonable investment return results. Another recommendation is a detailed economic study of the system proposed here. The most accurate economic data would be generated by several representative, detailed case studies of specific industrial facilities. Such studies shnild consider the smaller industries because, even though their energy consumption may be a small part of the national consumption, they likely represent a large number of installations. Note that this report is not of the same nature as a design study, and the information generated within is not sufficient for a detailed economic assessment of any of the case studies.

A nonter.hnical barrier that may exist in industrial utilization of the CCC is the interface problem between utility and in-house generated power. Shortages of generating capacity in some utilities in the nation should enhance the acceptance of cogeneration. 
Table 8.2. Thermodynamically Feasible savings of oil and gas with $\operatorname{ccc}^{\alpha}$

\begin{tabular}{lccc}
\hline & $\begin{array}{c}\text { Savings from process } \\
\text { beat cconversion } \\
\text { to zoal }\end{array}$ & $\begin{array}{c}\text { Savings from electrical } \\
\text { genezation by coal } \\
\text { cogeneration }\end{array}$ & Total \\
\hline $\begin{array}{l}\text { Nil, } \mathrm{m}^{3} / \mathrm{sec}(\mathrm{bb} 1 / \mathrm{day}) \\
\text { Natural gas, } \mathrm{m}^{3} / \mathrm{sec}\left(1 \mathrm{C}^{9} \mathrm{ft}^{3} / \text { day) }\right)\end{array}$ & $\begin{array}{l}1.60(370,000) \\
4,590(14.0)\end{array}$ & $\begin{array}{l}1.17(635,003) \\
1,228(3.75)\end{array}$ & $\begin{array}{l}2.77(1,505,000) \\
5,818(17.75)\end{array}$ \\
\hline
\end{tabular}

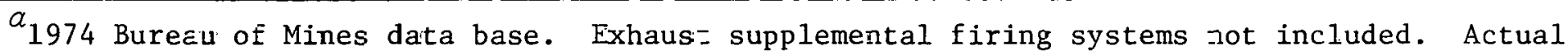
estimates are fcrr oil and gas, not energy equivalents. 
Cogeneration by industry is receiving much attention at this time and is highly recommended in the literature. ${ }^{2-4}$ The continued deve1opment of the equipment described in this report resulting in a vendormanufactured product would be instrumental in accelerating the implementation of coal-combustion cogeneration.

\section{$\underline{\text { References }}$}

1. J. E. Jones, Jr., et al., Systems Assessment of Atmospheric Fluidized Bed Combustion: Baseline Study - Draft, ORNL/TM-6208 (December 1977).

2. Thermo Electron Corporation, A Study of Inplant Electric Power Generation in the Chemical, Petroleum Refining and Paper and Pulp Industries, TE5429-97-76, 1976.

3. National Consumer Research Institute, Proceedings of the ERDA Conference on Cogeneration and Integrated Energy/Utility Systems, CONF$770632,1977$.

4. E. V. Sherry, Energy Conservation by Symbiosis, Air Products and Chemical, Inc., Allentown, Pa., 1977. 


\section{THIS PAGE WAS INTENTIONALLY LEFT BLANK}


APPENDIX 
THIS PAGE

WAS INTENTIONALLY

LEFT BLANK 
Table 1. List of industrial process-heat applications and annual requirements (1974) found from survey

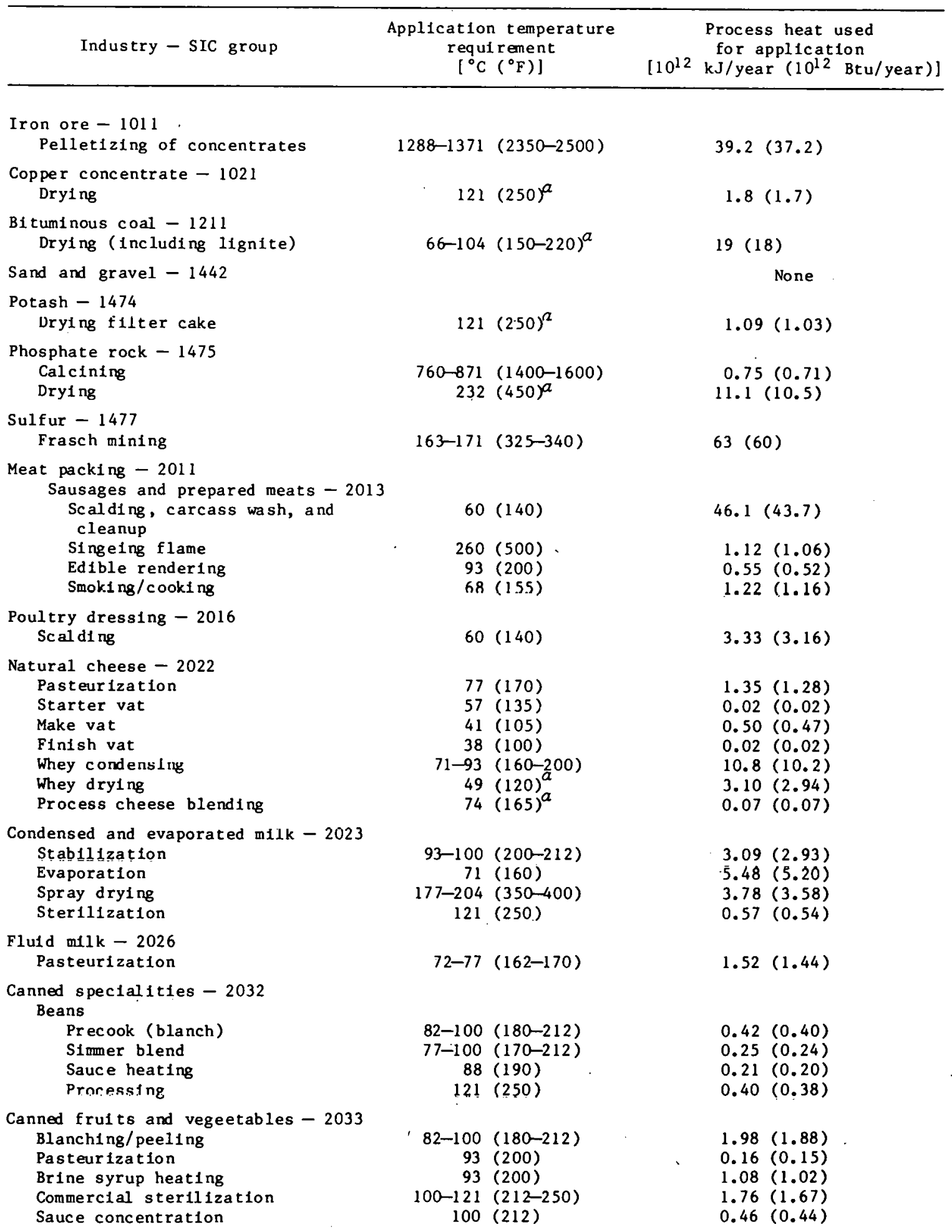


Table 1 (continued)

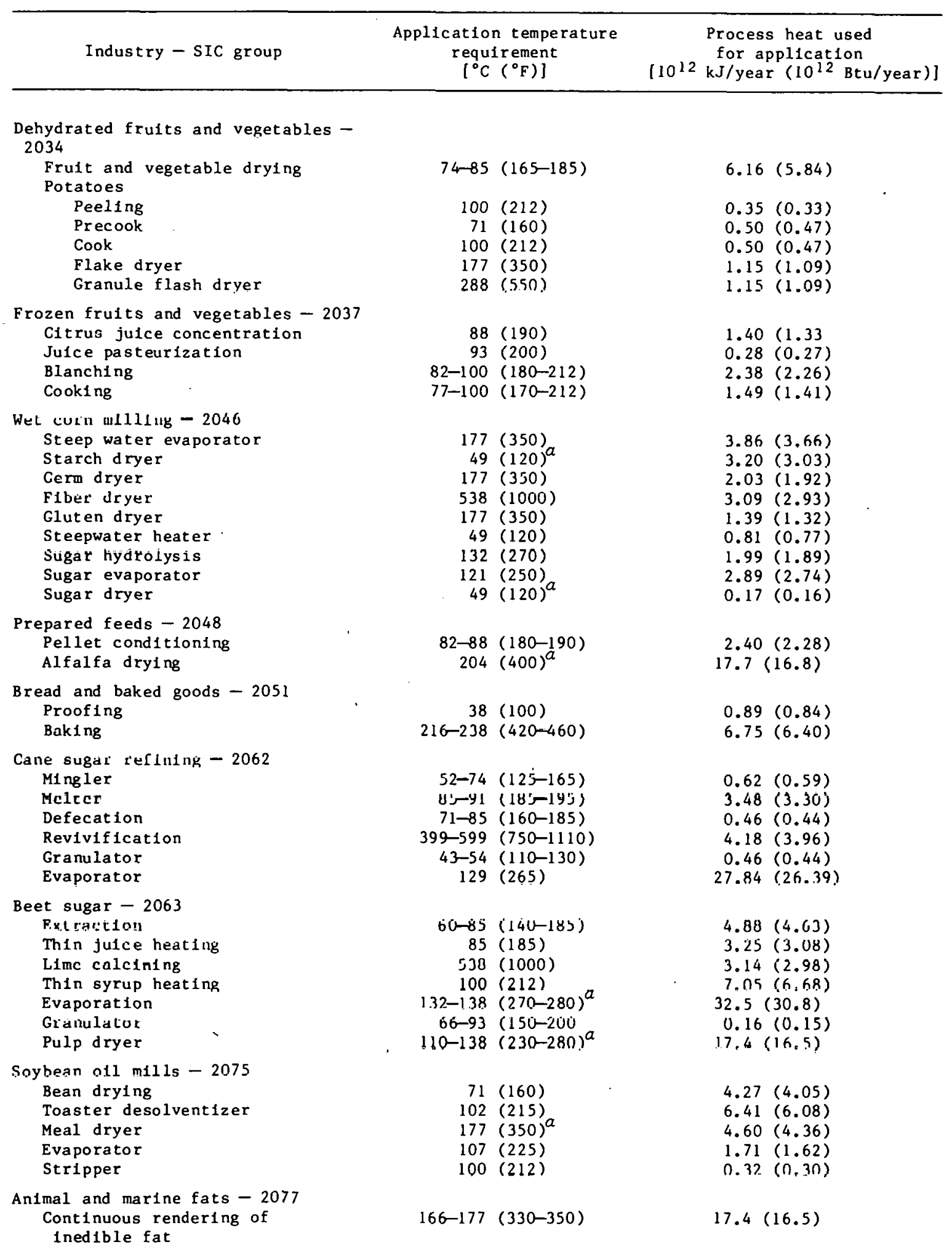


Tạble 1 (continued)

\begin{tabular}{|c|c|c|c|c|}
\hline Industry - SIC group & $\begin{array}{c}\text { Application temperature } \\
\text { requirement } \\
{\left[{ }^{\circ} \mathrm{C}\left({ }^{\circ} \mathrm{F}\right)\right]}\end{array}$ & {$\left[10^{12}\right.$} & $\begin{array}{l}\text { Process heat } \mathrm{u} \\
\text { for applicat1 } \\
\mathrm{kJ} / \text { year }\left(10^{12}\right.\end{array}$ & $\begin{array}{l}\text { used } \\
\text { ion } \\
\text { Btu/year)] }\end{array}$ \\
\hline $\begin{array}{l}\text { Shortening and cooking o1 - } 2079 \\
\text { o11 heater } \\
\text { Wash water } \\
\text { Dryer preheat } \\
\text { Cooking ofl reheat } \\
\text { Hydrogenation preheat } \\
\text { Vacuum deodorizer }\end{array}$ & $\begin{aligned} 71-82 & (160-180) \\
71-82 & (160-180) \\
93-132 & (200-270) \\
93 & (200) \\
149 & (300) \\
149-204 & (300-400)\end{aligned}$ & & $\begin{array}{l}0.76(0.72) \\
0.13(0.12) \\
0.63(0.60) \\
0.34(0.32) \\
0.39(0.37) \\
0.37(0.35)\end{array}$ & \\
\hline $\begin{array}{l}\text { Ma1t beverages }-2082 \\
\text { Cooker } \\
\text { Water heater } \\
\text { Mash tub } \\
\text { Gratn dryer } \\
\text { Brew ket tle }\end{array}$ & $\begin{aligned} 100 & (212) \\
82 & (180) \\
77 & (170) \\
204 & (400)^{a} \\
100 & (212)\end{aligned}$ & & $\begin{array}{l}1.61(1.53) \\
0.56(0.53) \\
0.63(0.60) \\
9.68(9.18) \\
4.20(3.98)\end{array}$ & \\
\hline $\begin{array}{l}\text { Distilled liquor }-2085 \\
\text { Cooking (whiskey) } \\
\text { Cookfing (spirits) } \\
\text { Evaporation } \\
\text { Dryer (grain) } \\
\text { Distillation }\end{array}$ & $\begin{aligned} 100 & (212) \\
160 & (320) \\
121-143 & (250-290)^{a} \\
149-204 & (300-400) \\
110-121 & (230-250)\end{aligned}$ & & $\begin{array}{ll}3.33(3.16) \\
6.61 & (6.27) \\
2.45 & (2.32) \\
2.05 & (1.94) \\
8.11 & (7.69)\end{array}$ & \\
\hline $\begin{array}{l}\text { Soft drinks - } 2086 \\
\text { Bulk contalner washing } \\
\text { Returnable bottle washing } \\
\text { Nonreturnable bottle washing } \\
\text { Can warming }\end{array}$ & $\begin{aligned} 77 & (170) \\
77 & (170) \\
24-29 & (75-85) \\
24-29 & (75-85)\end{aligned}$ & & $\begin{array}{l}0.22(0.21) \\
1.34(1.27) \\
0.45(0.43) \\
0.55(0.52)\end{array}$ & \\
\hline $\begin{array}{l}\text { Cigarettes }-2111 \\
\text { Drying } \\
\text { Rehumidification }\end{array}$ & $\begin{array}{l}104(220)^{a} \\
104(220)^{q}\end{array}$ & & $\begin{array}{l}0.45(0.43) \\
0.45(0.43)\end{array}$ & \\
\hline $\begin{array}{l}\text { Tobacco stemming and redrying }-2141 \\
\text { Drying }\end{array}$ & $104(220)^{a}$ & & $0.26(0.50)$ & \\
\hline $\begin{array}{l}\text { Finfshing plants, cotton }-2261 \\
\text { Washing } \\
\text { Dyeing } \\
\text { Drying }\end{array}$ & $\begin{array}{l}100(200) \\
100(200) \\
135(275)\end{array}$ & & $\begin{aligned} 16.2 & (15.4) \\
4.7 & (4.5) \\
23.4 & (22.2)\end{aligned}$ & \\
\hline $\begin{array}{l}\text { Fintshing plants, synthetic }-2262 \\
\text { Washing } \\
\text { Dyeing } \\
\text { Diyling dill lied setLling }\end{array}$ & $\begin{aligned} 93 & (200) \\
100 & (212) \\
135 & ((275)\end{aligned}$ & & $\begin{array}{l}37.9(35.9) \\
16.0(15.2) \\
24.5(23.2)\end{array}$ & \\
\hline Logg1ng camps - 2411 & & & None & \\
\hline $\begin{array}{l}\text { Sawmilis and planing mills }-2421 \\
\text { K1ln drying of lumber }\end{array}$ & $149(300)$ & & $66.9(63.4)$ & \\
\hline $\begin{array}{l}\text { Plywood - } 2435 \\
\text { Plywood drying }\end{array}$ & $121(250)$ & & $53.4(50.6)$ & \\
\hline $\begin{array}{l}\text { Veneer }-2436 \\
\quad \text { Veneer drying }\end{array}$ & $100(212)$ & & $61.0(57.8)$ & \\
\hline $\begin{array}{l}\text { Wooden furniture }-2511 \\
\text { Makellp a1r and ventilatinn } \\
\text { Kiln dryer and drying oven }\end{array}$ & $\begin{array}{ll}21 & (70) \\
66 & (150)\end{array}$ & & $\begin{array}{l}6.0(5.7) \\
4.0(3.8)\end{array}$ & . \\
\hline $\begin{array}{l}\text { Upholstered furniture }-2512 \\
\text { Makeup air and ventilation } \\
\text { Kiln dryer and drying oven }\end{array}$ & $\begin{array}{ll}21(70) \\
66(150)\end{array}$ & & $\begin{array}{l}1.5(1.4) \\
0.9(0.9)\end{array}$ & . \\
\hline
\end{tabular}


Table 1 (continued)

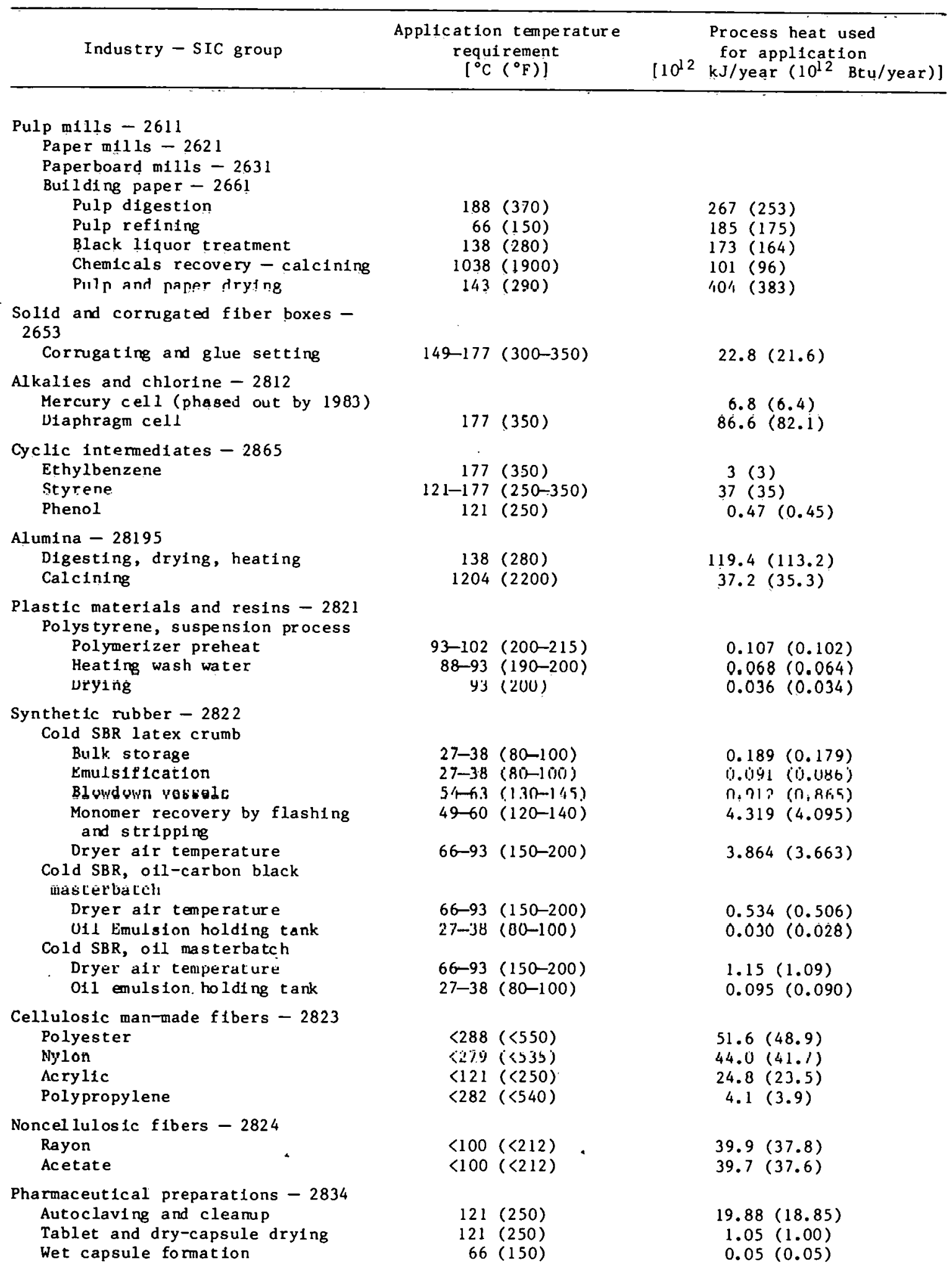


Table 1 (continued)

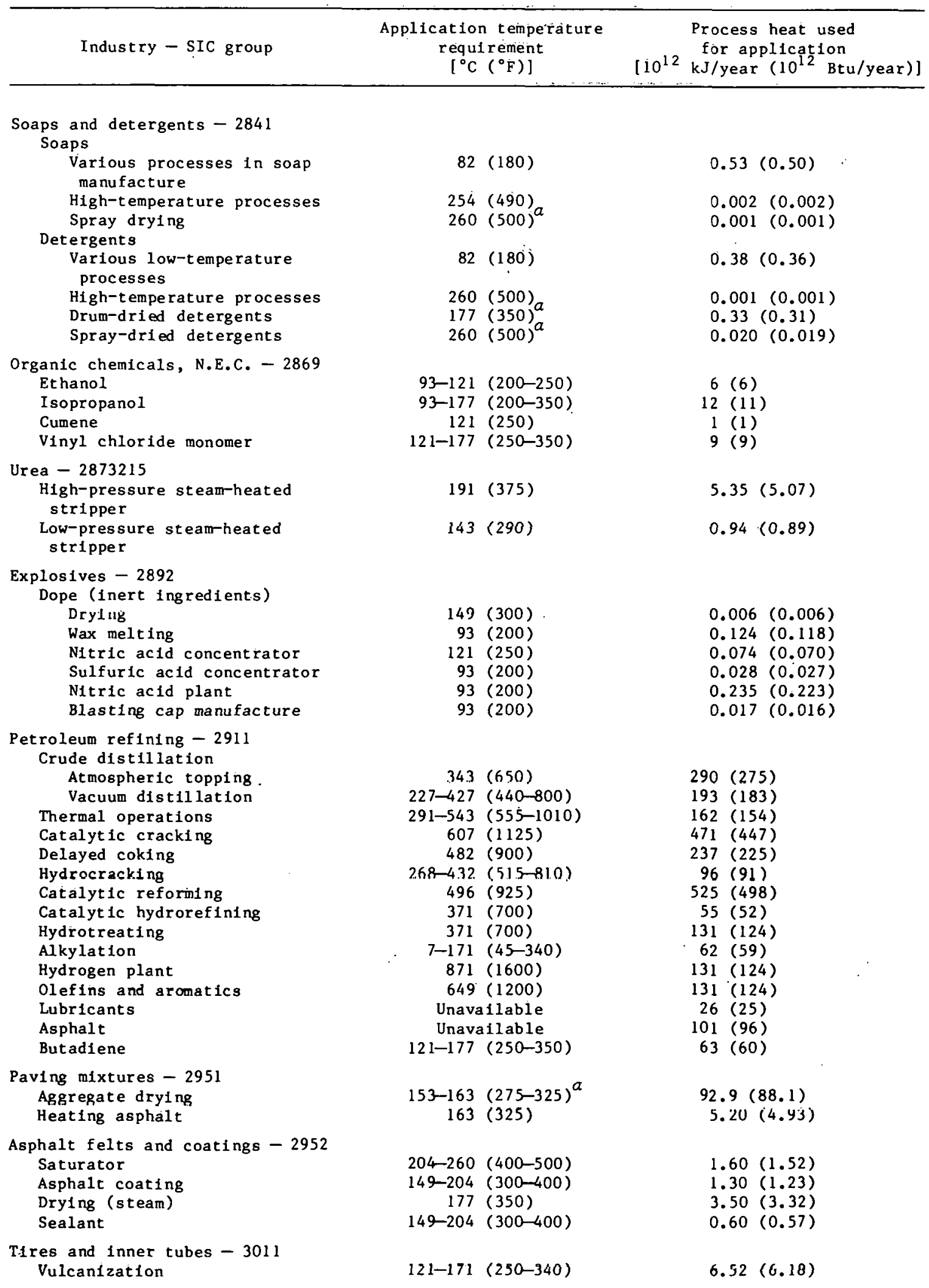


Table 1 (cont Inued)

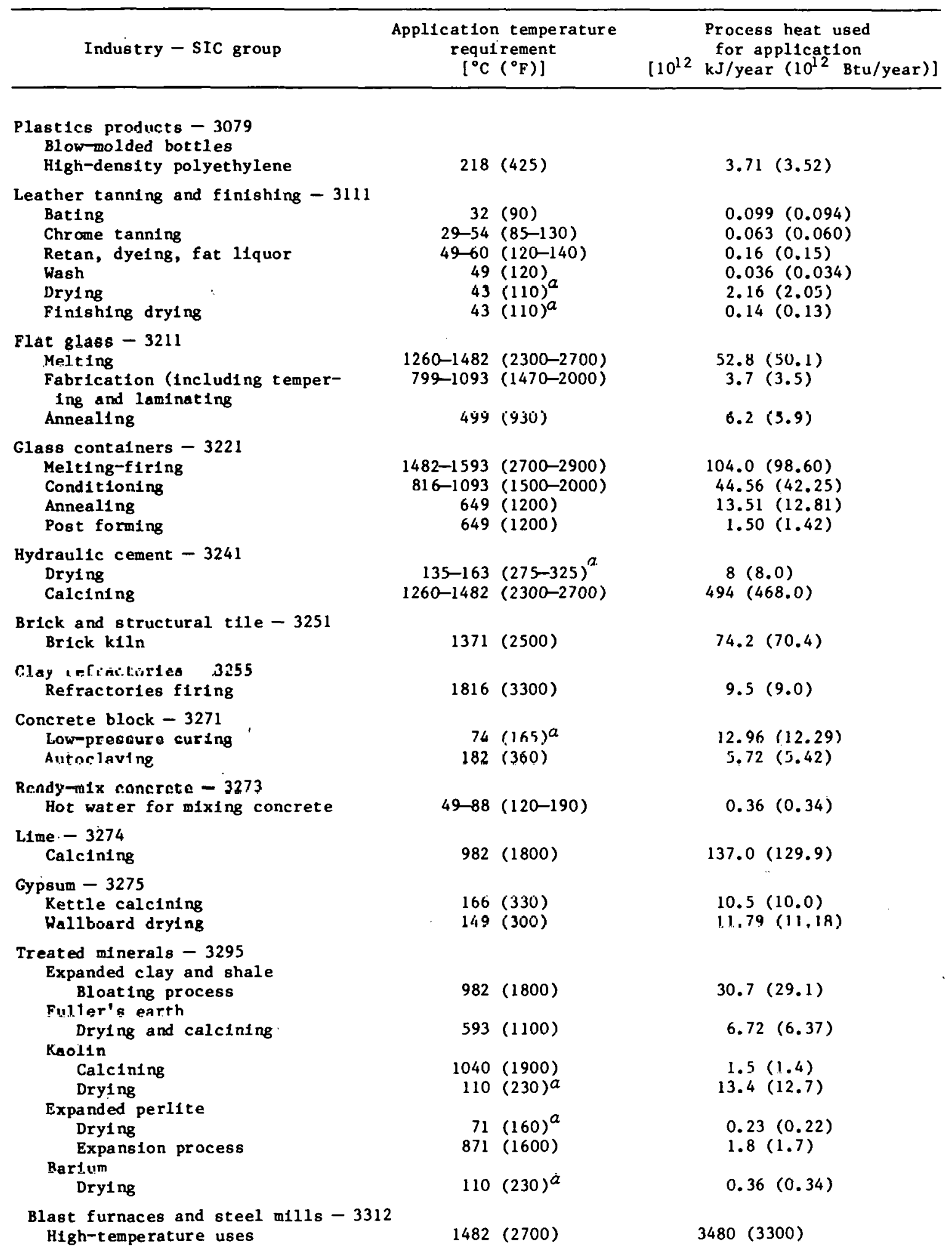


Table 1 (continued)

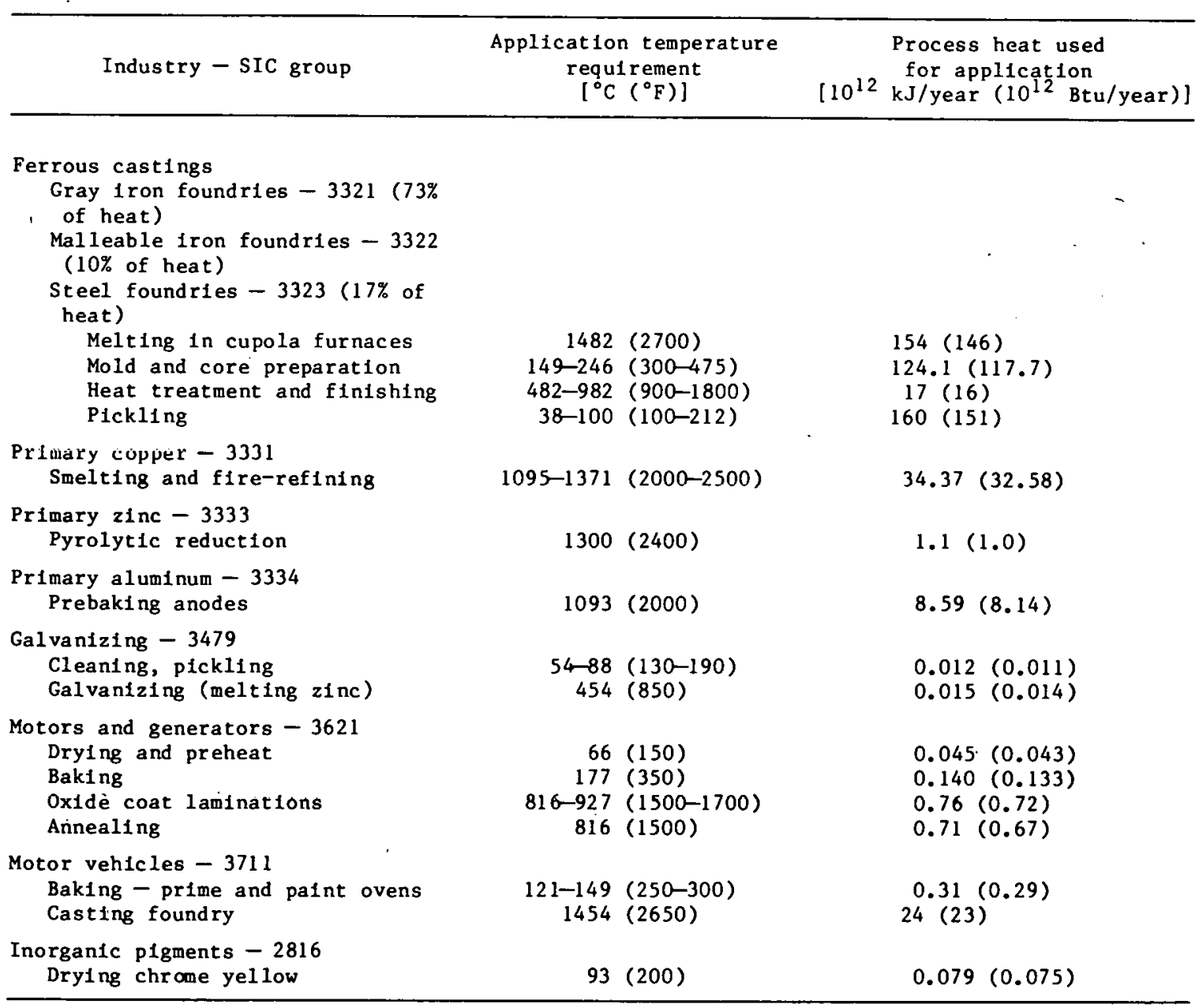
material.

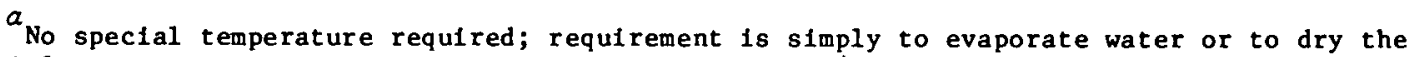

Source: Intertechnology Corporation, Analysis of the Economic Potential of Solar Thermal Energy to Provide Industrial Process Heat, Vol. 1,. Final Report, C0028-1 (NTIS CO0282y/1) (February 19/I). 
Table 2. Summary of process hea: requi rements, $10^{12} \mathrm{~kJ}\left(10^{12} \mathrm{Btu} /\right.$ year $), 1974$

\begin{tabular}{|c|c|c|c|c|c|c|c|c|}
\hline \multirow{2}{*}{$\begin{array}{l}\text { SIC } \\
\text { code }\end{array}$} & \multirow[b]{2}{*}{ Description } & \multirow{2}{*}{$\begin{array}{c}\text { Hot water } \\
{\left[<100^{\circ} \mathrm{C}\left(<212^{\circ} \mathrm{F}\right]\right]}\end{array}$} & \multicolumn{2}{|c|}{ Steam } & \multicolumn{3}{|c|}{ Direct heat/hot a1r } & \multirow[b]{2}{*}{ Rounded total } \\
\hline & & & $\begin{array}{c}{\left[100-177^{\circ} \mathrm{C}\right.} \\
\left.\left(212-350^{\circ} \bar{*}\right)\right]\end{array}$ & $\begin{array}{l}{\left[>177^{\circ} \mathrm{C}\right.} \\
\left.\left(>350^{\circ} \mathrm{F}\right)\right]\end{array}$ & $\begin{array}{l}{\left[<100^{\circ} \mathrm{C}\right.} \\
\left.\left(<212^{\circ} \mathrm{F}\right)\right]\end{array}$ & $\begin{array}{c}{\left[100-177^{\circ} \mathrm{C}\right.} \\
\left.\left(212-350^{\circ} \mathrm{F}\right)\right]\end{array}$ & $\begin{array}{c}{\left[>177^{\circ} \mathrm{C}\right.} \\
\left.\left(>350^{\circ} \mathrm{F}\right)\right]\end{array}$ & \\
\hline 1211 & $\begin{array}{l}\text { BLtuminous coal and } 11 g^{-} \\
\text {ifte }\end{array}$ & & & & & & $11.6(11)$ & $11.6(11)$ \\
\hline 1477 & Sulfur mining & & $.46 .4(44)$ & & & & & $46.4(44)$ \\
\hline 20 & Food and kindr $\Rightarrow d$ products & $53(60)$ & 290 & $105.5(100)$ & $10.6(10)$ & $100.2(95)$ & $15.8(15)$ & $586(555)$ \\
\hline 22 & Textile m111 pzoduets & $20(19)$ & $202(1911$ & $4.2(4)$ & & $72.8(6 \mathrm{~s})$ & $13.7(13)$ & $312(296)$ \\
\hline 24 & Lumber and wood products & $5.3(5)$ & $22.2(2 .:)$ & $4.2(4)$ & $111.8(105)$ & $4.2(4)$ & $73.9(70)$ & $222(210)$ \\
\hline 26 & Paper and alligd products & & $491(4651$ & & & & $99.2(94)$ & $590(559)$ \\
\hline 28 & Chemicals & & $1477(1400)$ & & & $475(450)$ & $264(250)$ & $2216(2100)$ \\
\hline 2911 & Petroleum refiting & & $126.6(1 \leq 0)$ & $401(308)$ & & & $2743(2600)$ & $3271(3100)$ \\
\hline 32 & S=one, clay, axd glass & $8.4(8)$ & $21.1(20)$ & $39.0(37)$ & & $25.3(24)$ & $1140(1081)$ & $1234(1170)$ \\
\hline 3312 & $\begin{array}{l}\text { Blast furnaces and steel } \\
\text { nills }\end{array}$ & & $168.6(6 j)$ & & & & $1806(1712)$ & $1875(1777)$ \\
\hline 3331 & $P=$ imary copper & $15.0(14.2)$ & & & $2.5(2 . \dot{4})$ & & $58.5(55.4)$ & $76.0(72)$ \\
\hline 3334 & P=imary aluminum & & & $40.5(38.4)$ & & & $66.6(63.1)$ & $108(102)$ \\
\hline $\begin{array}{l}3711 \\
3712 \\
3713\end{array}$ & $\begin{array}{l}\text { Aut omobile and truck } \\
\text { manufacturing }\end{array}$ & $1.3 .7(13)$ & $1.5(1.4)$ & & $22.5(21.3)$ & $10.6(10)$ & $1.0(0.9)$ & $49.6(47)$ \\
\hline & Rounded total & $126.6(120)$ & $2743(2600)$ & $594(563)$ & $148(140)$ & $688(652)$ & $6293(5965)$ & $10,592(10,040)$ \\
\hline & Percent of total & 1.2 & 25.9 & 5.6 & 1.4 & 6.5 & 59.4 & \\
\hline
\end{tabular}

Source: Survey of the Appicicatione of Solar Thermel Brespy Systems to Industrial Process Heating; Vol. 2, Industrial Process Heat Sumey, ID $27348 / 2$, Battelle Lisboratories (January IST7). 
ORNL/TM-6626/V1

Dist. Category UC-90e

\section{Internal Distribution}

1. T. D. Anderson

2. S. J. Ball

3. Seymour Baron

4. M. Bender

5. W. J. Boegly, Jr.

6. J. R. Buchanan

7. R. S. Carlsmith

8. D. A. Casada

9. J. E. Christian

10. R. G. Chenoweth, Jr.

11. J. A. Conlin

12. F. L. Culler

13. J. H. DeVan

14. H. L. Falkenberry

15. M. H. Fontana

16. E. C. Fox

17. A. P. Fraas (Consultant)

18. W. Fulkerson

19. L. C. Fuller

20. K. E. Gant

21-30. R. L. Graves

31. W. L. Greenstreet

32. M. P. Guthrie

33. R. H. Guymon

34. J. F. Harvey

35. E. C. Hise

36. R. S. Holcomb

37. J. M. Holmes

38. H. Inouye

39-48. J. E. Jones

49. M. A. Karnitz

50. 0. H. Klepper
51. J. O. Kolb

52. R. E. Kuhlmann

53. M. E. Lackey

54. Milton Levenson

55. R. E. MacPherson

56-60. L. E. McNeese

61. J. T. Meador

62. W. R. Mixon

63. F. R. Mynatt

64. L. F. Parsly

65. S. A. Reed

66. J. L. Rich

67. M. W. Rosenthal

68. G. Samuels

69. M. J. Skinner

70. C. B. Smith

71. I. Spiewak

72-76. J. R. Tallackson

77. J. F. Thomas

78. H. E. Trammell

79. D. B. Trauger

80. J. J. Tudor

81. M. E. Whatley

82. J. S. White

83. G. P. Zimmerman

84. Biology Library

85. Emergency Technology Library

86. MIT Practice School

87-88. Central Research Library

89. Y-12 Document Reference Section

90-93. Laboratory Records Department

94. Laboratory Records, RC

\section{External Distribution}

95. R. N. Abrams, VP, Gilbert Associates, Inc., P.0. Box 1498, Reading, PA 19603

96. Seymour Alpert, Manager, Process Development Fossil Fuel Department, Electric Power Research Institute, 3412 Hillview Avenue, P.0. Box 10412, Palo Alto, CA 94304

97. James W. Babcock, United Technologies Corporation, Power Systems Division, P.O. Box 109, South Windsor, CT 06074

98. R. C. Balfour, Balfour Lumber Company, Thomasville, GA 31792 
99-101. J. V. Basilico, Office of Research and Development, Environmental Protection Agency, Air, Land and Water Use, Waste Management Division, Room 3817-A, Washington, DC. 20460

102-104. Harold Benson, Mail Code EZ, Urban Systems Project Office, Johnson Space Center, National Aeronautics \& Space Adminstration, Houston, TX 77058

105. S. D. Berwager, FEA/DOE, Office of Program Development, Room 206, Old Office Building, Washington, DC 20461

106. W. C. Best, U.S. Army Facilities Engineering Support Group, Attention: FEFA-RTD, Fort Belvoir, VA 22060

107. Harold Beuther, Manager, Catalyst and Chemicals Research, Gulf Research and Development Company, P.0. Box 2038, Pittsburgh, PA 15230

108. S. B. Bram, Consolidated Edison Company of N.Y., 4 Irving Place, New York, NY 10003

109. T. T. Bramlette, Sandia Laboratories 8451, Livermore, CA 94550

110. R. D. Brooks, General Electric Company, K-1 Comhustion Ruiliting, F.0. Bü B, Sclieneclady, NY 12301

111. Wilson Cadman, Kansas Gas \& Electric Company, 201 N. Market St., Wichita, KS 76201

112. T. R. Casberg, Staff Mechanical Engineer, Directorate of Construction Standards and Design, Office of the Deputy Assistant, Secretary of Defense (Installation and Housing), The Pentagon, Washington, DC 20301

113. Steve Cavros, Office of Conservation, Department of Energy, Washington, DC 20545

114. A. T. Christensen, Manager - Program Development, General Electrir, 777 l.4th St., RJ, Wathinglull, DC 20005

115. R. A. Chronowski, Aqua-Chem Inc., Cleaver Brooks Division, P.0. Box 421, Milwaukee, WI 532000

Iib. E. L. Daman, VP, Foster Wheeler Corp., 110 South Orange Avenue, Livingston, $\mathrm{N} \mathrm{J} 07039$

11\%. F. R. JeSanti, General Manager - Marketing, Public Service Electric and Gas Company, 80 Park Place, Newark, NJ 07101

118. J. F. Dinwiddie, Office of Fossile Energy, Department of Energy, 20 Massachusetts Avenue, N.W., Washington, D.C. 20545

119. L. J. Dugas, Division VP, Commonwealth Edison Company, $7601 \mathrm{~S}$. Lawndale Ave., Ch1cago, IL 60652

120. P. A. Duker, VP, Customer and Marketing Policy, Detroit Edicon Company, 2000 Second Avenue, Detroi,t, MI 48226

121. John Eilering, VF, Commonwealth Edison Company, P.ก. Rnx 767, Chicago, IL 60690

122. Englneering Librarȳ, University of l'ennessee, Knoxville, TN 37916

123. S. I. Freedman, Fossil Fuel Utilization, Department of Energy, Germantown Mail Stop E178, Washington, DC 20545

124. D. A. Furlong, VP, Combustion Power Company, Inc., 1346 Willow Road, Menlo Park, CA 94025

125-127. R. J. Gallina, Supervisor Consumer Services, Baltimore Gas and Electric Company, 1508 Woodlawn Drive, Baltimore, MD 21207

128. R. L. Gamble, Foster-Wheeler Energy Corporation, 110 South Orange Avenue, Livingston, NJ 07039 
129. C. D. Glass, VP, Gulf States Utility Company, P.0. Box 2951, Beaumont, TX 77704

130. Martin Gutstein, Special Projects Branch, Lewis Research Center, National Aeronautics and Space Administration, Cleveland, $\mathrm{OH}$ 44135

131. John Hamrick, VP, Marketing, San Diego Gas and Electric Company, P.O. Box 1831, San Diego, CA 92112

132. J. R. Hof f́nann, HQDA (DAEN-FEP), Washington, DC 20314

133. J. S. Holdhusen, FluiDyne Engineering Corporation, 5900 01son Memorial Highway, Minneapolis, MN 55422

134. H. L. Jaeger, Westinghouse Electric Corporation, Long Range Development, Combustion Turbine Systems Division, Lester Branch, Box 9175, Philadelphia, PA 19113

135. A. A. Jonke, Chemical Engineering Division, Argonne National Laboratory, 9700 South Cass Avenue, Argonne, IL 60439

136. J. R. Kaye, Union Electric Company, 1901 Gratiot Street, P.o. Box 149, St. Louis, MO 63166

137. J. H. Kleinau, VP, Copeland Systems, Inc., 708 Enterprise Drive, Oak Brook, IL 60521

138. H. Landsberg, Co-Director, Energy \& Materials Division, Resources for the Future, 1755 Massachusetts Avenue, NW, Washington, DC 20036

139. R. I. LaRock, NASA Headquarters, Mail Code NT, 600 Independence Avenue, Washington, DC 20546

140. G. S. Leighton, Office of Conservation, Department of Energy, 1016 16th Street, NW, Washington, DC 20545

141. Albert M. Leon, Dorr-Oliver, Inc., 77 Haremeyer Lane, Stamford, CT 06904

142. G. L. Linsteadt, Head, Technology Utilization Office, Department of the Navy, Naval Weapons Center, China Lake, CA 93555

143. Eric Lister, Railway. Labor Building, 400 1st Street, Mail Stop 4128, Washington, DC 20545

144. Valmore Toise.1,1, Jr., Combustion Engineering, Inc., C-E Power Systems, 1000 Prospect Hill Road, Windsor, CT 06095

145-147. G. H. Lovin, Edison Electric Institute, 1140 Connecticut Avenue, $\mathrm{NW}$, Washington, DC 20036

148. Rene H. Males, Director, Energy Analysis and Environment Division, Electric Power Research Institute, 3412 Hillview Avenue, P.o. Box 10412, Palo Alto, CA 94303

149-151. H. H. Maschke, Department of Defense, HQDA (DAEN-MCE-U), Washington, DC 20314

152. J. L. Mason, VP - Engineering, The Garrett Corp., 9851-9951 Sepulveda Blvd., Los Angeles, CA 90009

153-177. Mathematica, Inc., c/o N. R. Friedman, Suite 2970, 475 L'Enfant Plaza West, SW, Washington, DC 20024

178. S. Moskowitz, Curtiss-Wright Corporation, One Passaic Street, Woodridge, NJ 07075

179. E. A. Myers, c/o Southern California Edison Company, 224 Walnut Grove Ave., Rosemead, CA 91770

180. Leon Nonemaker, Pennsylvania Power \& Light Company, Two North Ninth Street, Allentown, PA 18101 
181-183. M. H. Novinsky, Office of Planning and Development, Department of HEW - OFEPM - Room 504, 330 Independence Ave., SW, Washington, DC 20201

184. Ruth Perks, Department of Energy, Washington, DC 20545

185-194. C. W. Phillips, National Bureau of Standards, Room A146, Bldg. 225, Washington, DC 20234

195. David Pilati, Brookhaven National Laboratory, Bldg. 475, Upton, NY 11973

196. Mike Prior, IAEA Coal Research, 14/15 Lower Grosvenor Place, London SW1W OEX, England

197. R. H. Roberts, Pullman Kellogg, Division of Kellogg Inc., Research and Development Center, 16200 Park Row, Industrial Park Ten, Houston, TX 77084

198-207. J. H. Rothenberg, HUD-MIUS Program Manager, Department of Housing and Urban Development, 4517 th St., SWW, $\bar{R} m$ 8158, Washington, DC 20410

208-232. W. N. Saunders, Fossil Fuel Utilization, Department of Energy, Germantown Mail Stop E178, Washington, DC 20545

233. L. A. Schmidt, CEA Combustion, Inc., 61 Taylor Reed Place, Stamford, CT 06906

234. Marion Semchyshen, Director of Research, Materials Research for Molybdenum Development, Climax Molybdenum Research Laboratory, P.0. Box 1568, Ann Arbor, MI 48106

235. E. G. Sharp, Mitre Corp., 1820 Dolly Madison Blvd., McLean, VA 22101

236. J. Sherman, Department of Housing and Urban Development, 451 7 th Street, SW, Room 8158, Washington, DC 20410

237. A. R. Siegel, Director, Division on Community Development Research, Department of Housing and Urban Development, 4517 th Stre.e.t., SW, Ronm 8162, Washingt.nn, DS. 2041.

238. R. D. Smith, Combustion Power Company, 1346 Willow Park, Men1o Bark, CA 94025

239. H. W. Sternberg, Consultant, 1100 Ptarmigan Drive, No. 6, Walnut Creek, CA 94595

240. Carl Streed, Process Research and Development Division, Mobil Research and Development Corporation, Billingsport Road, Paulsboro, NJ 08066

241. Don Sykora, Gen. Manager, Marketing, Houston Lighting and Power Company, P.0. Box 1700, Houston, TX 77001

242. L. D. Taylor, Professor of Economics, University of Arizona, Tucson, AZ 85721

243. Norman Taylor, Supervisor, Gas \& Steam Meter Engineering Unit, Baltimore Gas and Electric Company, 300 Front Street Building, P.0. Box 1475, Baltimore, MD 21203

244. U.S. Army Engineer Research and Development Laboratories, Library, Fort Belvoir, VA 22060

245. U.S. Naval Civil Engineering Laboratories, Library, Port Hueneme, CA 93041

246. F. R. White, AiResearch Manufacturing Company of California, Garrett Corporation, P.0. Box 3413, Oak Ridge, TN 37830 
247. McCauly Whiting, Consultant, Dow Chemical Company, 2020 Dow Center, Midland, MI 48640

248. B. A. Wolfe, Babcock \& Wilcox Company, Contract Research Division, P.0. Box 835, Alliance, OH 44601

249. L. L. Radcliffe, DỌE, ORO

250. Office of Assistant Manager, Energy Research and Development, Department of Energy, ORO

251-503. Given distribution as shown in TID-4500 under category UC-90e, Coal Conversion and Utilization - Direct Combustion of Coal (25 copies - NTIS) 